\title{
PERSONALIA DER PERIODE VAN HET ENGELSCH BESTUUR OVER JAVA 1811-1816.
}

DOOR

Dr. F. DE HAAN.

De hierbeneden volgende Personalia zijn bestemd geweest voor een werk over het Engelsch bestuur, dat vele jaren geleden werd ondernomen en waartoe, behalve hetgeen in druk was verschenen, het Landsarchief te Batavia de stof leverde. Naar mijn beste weten is dat archief te dien einde geheel doorgewerkt. Op de talrijke aldus verkregen afschriften en uittreksels van oorspronkelijke stukken werd vervolgens een uitvoerig register samengesteld en met behulp hiervan alles langzamerhand gecopieerd onder bepaalde rubrieken en wel in de eerste plaats onder die der Personalia, opdat bij het bewerken van verdere rubrieken steeds zou kunnen worden nagegaan, welke betrekking een of ander persoon op een gegeven datum (in een brief of ander stuk) bekleedde. Dat zulks niet overbodig was, zal men bij het doorbladeren dezer Personalia wel bespeuren. Niet zelden immers werden ambtenaren ver buiten hun ressort met andere diensten belast en overplaatsingen waren ongewoon veelvuldig. Nadat mijne Personalia aldus voor elkaar waren gebracht, kwamen andere rubrieken aan de beurt, te beginnen met die van kleineren omvang, bijv. de koffiecultuur, de suikercultuur, het postwezen, de vaccine enz. De meer omvangrijke, zooals rechtspraak, landrente, werden voor het laatst bewaard, teneinde aan deze lastige onderwerpen de volle aandacht te kunnen wijden, nadat mijne kennis door den voorafgeganen arbeid omvangrijker en solieder zou zijn geworden. Wanneer dan eindelijk elke rubriek in chronologisch en innerlijk verband voor mij zou liggen, kon een schema worden ontworpen, eerst voor elk onderdeel, daarna voor een samenvattend overzicht in boekvorm, waaraan eene uitgave van belangrijke oorspronkelijke stukken desgewenscht zou kunnen worden toegevoegd in den vorm van een Engelsch plakaatboek op de wijze van het Nederl.-Indisch Plakaatboek van Mr. J. A. van der Chijs.

D1. 92. 
$\mathrm{Om}$ dit eindresultaat te bereiken was uiteraard een onverdroten copieeren noodig, teneinde alles wat samenhoorde bijeen te brengen uit de massa verzamelde gegevens, een monnikenwerk zonder vooringenomenheid of partijzucht, niets weglatend, verhelend of misduidend.

Zoo was nu de voorarbeid een eind gevorderd, toen schrijver dezes zich plotseling voor eene andere en meer dringende taak geplaatst zag, die zijn verderen Indischen diensttijd geheel in beslag nam. Bij zijne repatrieering pakte hij alles, wat op dit werk betrekking had, in eene kist. met het voornemen den arbeid in Nederland te voltooien. Dat kwam echter anders uit. Eenmaal buiten de oude, vertrouwde archiefomgeving getreden, bleek de bezieling, zonder welke die arbeid onmogelijk was, zich in de kocle Nederlandsche atmosfeer spoorloos te hebben opgelost. De kist met papieren bleef gesloten, de inhoud kon beschimmelen en verbleeken.

Totdat eindelijk het Bestuur van het Koninklijk Instituut de zaak eens op het tapijt bracht en voorstelde, eene of andere geordende rubriek in het licht te geven. Daartegen moest ik echter bezwaar maken, omdat alsdan een enkel onderwerp, laat ons zeggen het postwezen, zou worden voorgesteld zooals het was onder het Britsch bestuur over Java, terwijl men niets samenhangends zou kunnen toonen omtrent datzelfde postwezen voor of na die korte periode. Welk nut zulk eene publicatie kon hebben, was niet duidelijk; wel vond $\mathrm{ik}$, dat het heele werk over dat bestuur aldus uit zijne voegen zou raken. Wilde men iets publiceeren, dan zouden dat de Personalia moeten zijn, die op zichzelf in zekere mate een oordeel over het Britsch bestuur mogelijk maken en in drukvorm een hulpmiddel zouden aanbieden bij alle verdere onderzoek.

Ziedaar de wordingsgeschiedenis dezer publicatie. De Personalia omvatten bizonderheden omtrent nagenoeg elken ambtenaar, die tijdens de bedoelde periode op Java gediend heeft, tot in de lagere rangen toe. Alleen het allerkleinste goedje zal men er niet vinden, doch evenmin den hoofdpersoon, den Lieutenant Governor Raffles. Diens levensomstandigheden zijn voldoende bekend, een oordeel echter over Raffles als bewindsman wenschte ik niet te vormen, veel min uit te spreken, voordat ik al zijne ambtelijke verrichtingen had nagegaan, dat is dus zijne handelwijze in elke afdeeling van het onderzoek, en daar die rubrieken nog lang niet alle waren bijeengebracht en nog heel niet samengevat naar haren korten inhoud, was eene beoordeeling der leidende kracht in het Engelsch bestuur na- 
tuurlijk niet mogelijk. Over andere personen is hier en daar in de Personalia wèl een oordeel uitgesproken, zooals zich dat uit hunne handelingen aanbood.

De bronnen voor de navolgende aanteekeningen waren: eerstens de gedrukte (de Java Government Gazette, de twee verzamelingen Proclamations, gedrukt te Batavia in 1813 en 1816, de aldaar ter perse gelegde verzameling stukken in zake de aanklacht van Raffles door Gillespie; verder de beneden opgenoemde literatuur); tweedens de geschrevene: Proceedings (ook: Consultations genoemd) of the Lieutenant Governor in Council in the Public Department, en talrijke bundels brieven en andere stukken, die het ontbreken der Proceedings in the Judicial and Police Department, in the Military Department, in the Foreign Dependencies Department, in the Revenue Department (deze laatste moeten omstreeks 1840 nog aanwezig zijn geweest) en in the Secret and Political Department (van laatstgenoemde kreeg de Council geen kennis) eenigermate aanvullen. Van de vergaderingen der Britsche Regeering over Java werden de notulen, voor zij in het net werden geschreven, verdeeld over bovengenoemde Departments; alles wat bijv. de Revenue betrof, kwam in het deel Revenue, enzoovoorts. Toen zij dus het eiland verliet, behoefde zij enkel hare Proceedings in de Departments, die zij geheim wenschte te houden, uit het archief te lichten. Het Public Department, dat te Batavia bleef berusten, zal natuurlijk verreweg het omvangrijkst zijn geweest; dit is nog compleet voorhanden, in leer gebonden in zeer groote folianten, wemelend van de domste fouten. Die domme fouten duiden op een der vele moeilijkheden van Raffles' bestuur, het gebrek aan geschoold personeel. In dit opzicht zijn onze Personalia zeer welsprekend. Terwijl men daarin slechts enkele Britsch-Indische bestuursambtenaren aantreft (Hope, Blagrave, Lawrence, Robinson, Macquoid) ontmoet men des te meer militairen van hoogeren en lageren rang, sommigen King's officers (dienend bij tijdelijk in Indië verblijvende regimenten), anderen in dienst bij de Engelsche O.-I. Compagnie, hetzij bij een Europeesch regiment of bij de Sepoys. De King's officers, waaronder mannen van geboorte en fortuin niet zeldzaam waren, gaven met hunne dames den toon aan in het maatschappelijk verkeer en hebben daardoor de vroegere verindisching van het bestuurscorps krachtdadig tegen gegaan. Vooral wordt echter onze aandacht getrokken door de officieren van gezondheid, die onder Raffles eene bestuursfunctie uitoefenden, eerste krachten als Assey, Crawfurd en Hopkins, ook John Leyden. Eindelijk is er de categorie 
van fortuinzoekers, aan hunne spits Admiraal Stopford, die op zijn aandeel in den buit afkwam, en dan een Barrett, een Bingley, een Addison en anderen, die een baantje zochten; wie maar behoorlijk Engelsch verstond, kon, zooals Francis, zijn brood ruimschoots verdienen. Naast al deze Engelschen maken de Nederlandsche ambtenaren een middelmatig figuur. Gelukkig dat de schitterende gaven van Muntinghe door Raffles zoo goed zijn benut en zoo hoog gewaardeerd. Andere goede krachten (Van Haak, Van Sevenhoven, de beide broers Veeckens) wenschte hij on hunne politieke gezindheid niet te gebruiken; Rothenbuhler en Van IJsseldijk schijnen vrijwel versleten geweest te zijn; Nic. Engelhard hield zich afzijdig en onder de overigen school veel kaf. De beide Nederlanders, die voortdurend in Engelschen dienst zijn gebleven als Resident, Doornik en Van Naerssen, deden weinig meer dan hun traktement innen. Dat ook het Britsche personeel niet van kaf vrij was, blijkt aan Heyland en Roxburgh.

Verwonderlijk echter blijft de bekrompenheid der personeelsformatie. In eene residentie treft men natuurlijk een Resident. Hem staat een Assistant Resident terzijde, die echter ook wel als ,writer” wordt betiteld, wiens emplooi inderdaad uit klerkenwerk bestaat, maar die niettemin zijn chef bij afwezigheid vervangt. Soms is er nog een Europeesche pakhuis- of havenmeester, en dat is dan ook alles, behalve eenige inlandsche schrijvers, oppassers en mandoers. De Resident, dikwijls een Engelsch officier, verstaat natuurlijk noch Maleisch noch eene andere op Java gebruikelijke taal; zijn Assistant zal daarin ook wel niet hebben uitgeblonken, en met zijn tweeën bedisselen zij niettemin den aanslag der landrente in dat heele gewest, eerst dessagewijs, later zelfs den individueelen aanslag. In verband hiermee krijgt dan een landmeter soms opdracht om eene residentie in kaart te brengen. En dat doet zoo iemand dan. Maar dat is niet alles. Men is Resident en wordt belast met maandenlange werkzaamheden buiten zijn ressort; men dient in eene residentie en ziet zich den aanslag in eene andere opgedragen. Begint men zich ergens wat thuis te voelen, dan komt eene overplaatsing. Voegt men daarbij de volkomen ontstentenis van Engelsche literatuur omtrent Java, van kaarten, van woordenboeken, de gebrekkige verkeersmiddelen, de onwetendheid, die onder de op Java wonende Nederlanders regel was, ook wat Engelsch en inlandsche talen betreft, dan ligt de voorloopige conclusie voor de hand, dat of het inlandsch bestuurspersoneel enorm veel arbeid verzette, òf (en met meer schijn) dat 
alles met den Franschen slag ging. Ook in het financieele zien wij vreemde dingen. Immers de traktementen der ambtenaren blijken aan wisselingen onderhevig, die veel willekeur en eene lastige contrôle doen onderstellen. De hoogere betrekkingen werden ruim gesalarieerd, in Spaansche Dollars à 64 stuiver en Java Roepijen à 30, soms ook in Sicca Roepijen à 31 1/2. Kwam daarbij nog het zeer ruime salaris als militair, dan kon een Resident leven als een prins. Maar men vindt ook een „Resident” van Banjoewangi op 80 Sp. D., een van Bawean op 30. Terwijl Dalgairns als Sub-Treasurer 2.000 Java Roep. per maand heeft, dus 3.000 gulden, trekt Muntinghe als Raadslid slechts $500 \mathrm{Sp}$. D., dus 1.600 . Vooral de zonderlinge benefices, die aan Hope toegestopt worden, duiden op leemten in het beheer der financiën. De vele insolvente boedels wijzen, wat de burgerlijke maatschappij betreft, in dezelfde richting. In de trage opvolging van gegeven orders toont zich soms een geest van laissez-faire. Raffles was persoonlijk rusteloos werkzaam, en hij werkte zeer snel; de uitvoerigste stukken vlogen hem uit de pen en hoe er in zijne onmiddellijke omgeving werd gearbeid, toonen de personalia van Addison. Om schrijfwerk te besparen, gelastte de Lieutenant Governor, alle aan hem gerichte stukken in duplo te zenden. Op het eene stuk schreef hij dan in margine zijne beschikking, die in margine van het andere, dat aan den afzender terugging, werd gecopieerd. Deze compendieuse briefwisseling heeft ten gevolge gehad, dat vele zaken, die op het eene bureau later te zoek zijn geraakt, in het archief van het andere bewaard zijn gebleven, maar het naslaan der retroacta zal er niet door vergemakkelijkt zijn. Ook Raffles' beschikkingen gedurende zijne vele reizen kwamen niet altijd ter kennis van den Council en den Accountant.

Tot zoover deze inleiding. Wie onze droge Personalia mocht willen doorzien, kan zich, naar onze meening, eene vrij juiste voorstelling vormen van het ambtelijk levein cin bedrijf op Java, een honderd en meer jaren geleden. Hier en daar valt ook een zijlicht op het dagelijksch bestaan dezer eigenaardige koloniale maatschappij, waarvoor overigens de Java Government Gazette het beste inlichtingbureau is.

Bij het aanhalen onzer bronnen zijn de volgende afkortingen gebruikt :

Addison (G. A.), Original familiar correspondence between residents in India including sketches of Java. Edit. by Mrs. M. Brown, Edinburgh 1846. 
Boulger (Demetrius Charles), The life of Sir Stamford Raffles, London 1897.

Bijdr. = Bijdragen tot de Taal-, Land- en Volkenkunde van Nederlandsch-Indië.

Campbell (Donald Maclaine), Java, past and present, London z. j. (1915), 2 deelen.

Carey (W. H.), The good old days of Honorable John Company, Simla 1882.

Collet (Octave J. A.). L'ile de Java sous la domination française, Bruxelles 1910.

Conquest $=$ Thorn (W.), Memoir of the conquest of Java, London 1815 .

Crawfurd (J.), History of the Indian Archipelago, Edinburgh-London 1820 (drie deelen).

Crawfurd (J.), A descriptive dictionary of the Indian islands \& adjacent countries, London 1856.

Deventer (M. L. van), Het Nederl. gezag over Java en Onderhoorigheden sedert 1811, Eerste Deel, 1811-1820, 's-Gravenhage 1891.

Doeff (H.), Herinneringen uit Japan, Haarlem 1833.

Doren (J. B. J. van), Fragmenten uit de reizen in den Indischen Archipel, Amsterdam 1854.

Id. Reis naar Nederlands Oost-Indië, 's-Gravenhage 1851.

Egerton (H. E.), Sir Stamford Raffles. England in the Far East,

London 1900 (Builders of Greater Britain, 8).

Gaz. = Java Government Gazette. Een weekblad met extranummers, van af 28 Febr. 1812 tot het einde van het Britsch bestuur.

Graaff $=$ Brieven van en aan Mr. H. J. van de Graaff, 1816-1826,

Uitgegeven door P. H. van der Kemp. Verhand. Bat. Gen. deel

52, Batavia 1901.

History $=$ Raffles (Th. Stamford), The history of Java, London

1817, 2 deelen. Second edition, London 1830, 2 deelen. Geciteerd is naar den eersten druk.

Levyssohn Norman (Mr. H. D.), De Britsche heerschappij over Java en Onderhoorigheden (1811-1816), 's-Gravenhage 1857.

Mill (James), The history of British India, London 1817, 3 deelen. (Laatste uitgave van 1858 door H. H. Wilson, 10 deelen).

Minto $=$ Life and letters of Gilbert Elliot, first Earl of Minto, from

1752 to 1806 , edited by his great-niece the Countess of Minto, London 1874, 3 deelen. 
Lord Minto in India. Life and letters etc. from 1807 to 1814, while Governor-General of India, edited u.s., London 1880.

Prior (J.), Beschrijving eener reis, naar de Indiesche zee, met het fregat de Nisus (uit het Engelsch), Amsterdam 1820.

Proc. $=$ Proceedings of the Lieutenant Governor in Council in the public Department (handschrift, zie boven). De vermeldingen dezer bron zijn wel eens wat beknopt; de hierna volgende datum kan bijv. beduiden, dat in de op dien datum behandelde Proceedings eene zaak ter sprake is gekomen of vermeld wordt in een alstoen geïnsereerd stuk.

Roo (Dr. L. W. G. de), De opkomst van het Nederlandsch gezag in Oost-Indië, Verzameling van onuitgegeven stukken uit het Oud-Koloniaal Archief, uitgegeven en bewerkt door Jhr. Mr. J. K. J. de Jonge en M. L. van Deventer. Supplement op het dertiende en laatste deel: Documenten omtrent Herman Willem Daendels, 's-Gravenhage 1909, 2 deelen.

Roorda van Eysinga (P. P.), Verschillende reizen en lotgevallen van S. Roorda van Eysinga; mitsgaders die van deszelfs zoon, Amsterdam 1830-1832, 4 deelen.

Thomson (J. T.), Translations from the Hakayit Abdulla (bin Abdulkadar), London 1874.

Troost Gzn. (P.), Aanteekeningen gehouden op eene reis om de wereld, Rotterdam 1829.

Waeij: Blik op de afgelegde loopbaan van Hendrik Willem van Waeij (autobiographie van 1873, handschrift in het Landsarchief te Batavia).

Widow $=$ Memoir of the life and public services of sir Thomas Stamford Raffles... particularly in the Government of Java, 1811-1816, and of Bencoolen and its dependencies, 1817-1824. By his widow, London 1830.

Abraham (Thomas) komt te Bat. den 11en Maart 1816 samen met Fendall en Boggie, legt den 12en den eed af en neemt zitting als Member of Council, en wel boven het lid Cranssen. Werd President van het Revenue Committee. In het laatst van dat jaar was hij als commissielid werkzaam te Bandjarmasin; keerde van daar naar Java terug, en bleef hier ook in 1817 werkzaam als lid van het afgetreden bestuur.

Adams (Alcrander), Lieut. Col. H. M. 78th regiment of Foot, 
neemt deel aan den aanval op Meester Cornelis (Conquest p. 19 en 72 ) ; wordt 24 Oct. 1811 door Minto benoemd tot militair commandant te Samarang, d.i. commandant van the Center Division of the army (op 1.000 Sicca Rup. extra traktement) en tot Resident te Solo (Proc. 1 Nov. 1811); komt 4 Nov. 1811 te Samarang aan als opvolger van Lieut. Col. J. Watson; neemt 11 Nov. de residentie Sclo over van Van Braam en wordt 12 Nov. door den Soenan ontvangen, samen met Crawfurd. Minto schrijft in zijn rapport van 6 Dec. 1811, dat Adams, ofschoon lager in ancienneteit dan Gibbs en een minder belangrijk militair commando voerende, hetzelfde totale traktement geniet (zoodat dus Adams' civiel salaris hooger was). Den 16 Juli 1812 schrijft Raffles te Samarang, dat in consequence of the military command of the Eastern Division of the Island having devolved upon Col. Adams, deze tevens de opvolger van Col. Gibbs zal zijn in the civil charge at Sourabaya; hij treedt dus af als Resident te Solo. Op dit laatste slaat denkelijk wat de Regeer. den 8 Aug. 1812 aan het Opperbestuur schrijft, dat hiermee the commission of Col. Adams is vervallen. Blijkens Proc. 10 Oct. 1812 trok hij nu als Resident 500 \$, terwijl elders blijkt, dat hij in April 1814 als officier 2284 Son. Rup. p. m. genoot. Zijne dubbele benoeming staat in Gaz. 25 Juli en Gener. Orders 28 Juli 1812. Hope schrijft 7 Nov. 1813, dat er bij zijne eigen optreding als Res. te Solo heel wat ontstemming aan dat Hof heerschte from the want of due attention to the European habits and manners of the chiefs belonging to the Court (het Hof liet alle dagen spijzen en dranken uit de keuken van den Resident halen, wat Adams vermoedelijk afgewezen zal hebben met de opmerking dat hij geen restaurateur was). De Solosche Rijksbestierder merkt in een brief van 24 Jan. 1812 op, dat indien ,,den Heere Resident Adams Maleids spreeken kon", de zaken beter zouden vlotten. Den 5 Aug. 1812 trad hij te Soerabaja op als Deputy Civil Commissioner. Den 5 Nov. 1812 werci hij president der Commissie voor den landverkoop aldaar. Proc. 17 Sept. 1813 deelt Raffles mee, dat A. door hem is belast met den aanslag van Soerabaja, daaronder begrepen Sidajoe, Grissee, Lamongan, Bangil, Malang en Pasoeroean. Adams' correspondentie ter zake doet hem kennen als een braaf en bescheiden man, die veel op zich durfde nemen, maar volstrekt geen hoogvlieger. In April 1814 werd hij ingedeeld bij de militaire expeditie naar Bali; hij verliet zijne standplaats 2 Mei 1814, leaving the civil and military charge of Sourabaya in the hands of captain Davy; den 25 Mei 
bericht A. zijn terugkeer te Soerabaja. Bij schrijven van 1 Aug. 1814 deelt de Regeer. mede, dat hij te Samarang Eales moet gaan vervangen als Resident en als commandant der Center Division. Den 22 Aug. gaf A. de residentie over aan Pemberton; de Gaz. van 3 Sept. bevat een afscheidsadres der Hollandsche ingezetenen van Soerab. aan A. en diens antwoord daarop. Den 1 Sept. 1814 nam hij de residentie Samar. over van Eales, doch reeds 21 Oct. 1814 vroeg hij ontslag naar aanleiding van een schrijven der Regeer. van 18 Oct., dat hij spoedig van zijne civil duties zou worden ontheven wegens zijne vele bezigheden en the absolute necessity that the Resident should himself preside in the Resident's Court, iets wat, notabene, bij art. 85 en 90 der Regulation van 11 Febr. 1814 expres bepaald was dat kon worden overgelaten aan 's Residents Deputy or Assistant ! Cotes, een gunsteling van Raffles, wordt bij schrijven van 8 Nov. 1814 tot waarnemend Resident van Samarang benoemd, met ontheffing van A.; deze laatste behield echter (Gaz. 19 Nov.) het commando over both the Samarang and Sourab. Divisions. Den 25 Mei 1815 kwam A., middelerwijl tot Major-General bevorderd, met zijne echtgenoote te Batavia aan en vertrok van hier den 1 Juni met het schip Broxbournbury naar Europa, samen met zijn strijdmakker Eales; de Gazette van 3 Juni 1815 bevat een afscheidscompliment van den Vice-President in Council aan hen beiden. Adams maakt den zeer sympathieken indruk van iemand, die te fatsoenlijk was om de streken van Raffles te kunnen begrijpen. Men zou gaarne meer van hem weten. Heeft Adimonggolo hem te Samarang gewipt?

Addison (George Augustus) geb. te Calcutta 1792, zoon van een hoofdambtenaar, zeer jong naar Engeland gezonden, kwam op 16 jarigen leeftijd naar Br.-Indië terug. Van hem is in 1846 uitgegeven eene serie brieven, beginnend met Maart 1811, toen hij sedert een paar jaar medeondernemer was van eene indigoplantage. Deze brieven, overigens zonder eenig belang, toonen hem als een bizonder, doch nagenoeg uitsluitend literarisch, ontwikkeld jongmensch, met eene verbazende belezenheid vooral in de Engelsche letteren, en even goed bekwaam tot het vervaardigen van eene Latijnsche ode als de vertaling van een Perzisch gedicht. Een vers van hem (zie zijne brieven p. 138) op de hookah vindt men in Gaz. 6 Juni 1812 als geschreven door iemand te Samarang. Overigens onder vrouwen opgevoed, bij voorkeur met vrouwen correspondeerend, zonder 
eenigen lust voor sport en politiek. De mislukking van zijne indigoonderneming bracht hem er toe, naar eene Gouvernementsbetrekking te solliciteeren; hij kreeg toen den raad naar Java te gaan en arriveerde aldaar 3 Dec. 1813 met aanbevelingen van Lord Minto en andere invloedrijke personen, zoodat hij terstond bij Generaal Nightingall kon gaan logeeren, die zelf, tijdens Raffles' reis over Java, het paleis te Buitenz. had betrokken. Zonder dat hij nog eene betrekking had, gaf Assey hem al vast employment in writing letters, making extracts etc. etc., which teaches me much and gives me a good insight into the way business is carried on here. $\mathrm{Na}$ zich eenige weken aldus voorbereid te hebben, ging de 21-jarige den Lieut. Gov. opzoeken, die hem den 24 Jan. 1814 te Samarang benoemde tot Assistant Secretary to Government in the Revenue Department, en bovendien tot waarnemend Secretaris van den Lieut. Gov.; dienzelfden dag begonnen zijne werkzaamheden! Eenige dagen later kwam hij met R. te Buitenzorg terug; ,We travelled with such rapidity (dat was namelijk R.'s gewoonte) and our reception everywhere was so bruyant and flourish-of-trumpet fashion", dat zijn hoofd er van duizelde. Bij schrijven van 14 Maart 1814 werd behalve het Revenue Dept. ook het Judicial and Police Dept. op zijne jonge schouders gelegd, terwijl zijn salaris werd vastgesteld op 1.200 Java Roep. En toen een paar weken later Assey naar Bengalen zou vertrekken, werd Proc. 2 April 1814 onze jongman tot diens vervanger aangewezen als Secretary to the Lieut. Gov. ; maar bovendien, schrijft hij zelf, zou hem (behalve zijn gewone werk) nog worden opgedragen het Secret and Political Departm., Foreign Dependencies en Military Dept.; ja, alleen om Dupuy niet te krenken, was hij niet met de volledige waarneming van Assey's werkzaamheden belast en had men diens betrekking vacant gelaten (wat niet precies juist is; zie onder Dupuy). Zijn werk beschreef hij dan ook als everything to learn and yet to proceed at once as if everything had been learned .... They keep me closely to my desk. I generally begin at daylight and with only such gross intervals as breakfast and dinner, keep at it till eleven at night, ook omdat Cotes een achterstand had gelaten en het juist de tijd was voor de verzending van brieven naar Bengalen en Engeland. Hij woonde ten paleize te Buitenz. en had daar ook zijn bureau. Nog voordat Assey terug was, werd Addison 1 Juli 1814 met Bauer in commissie naar O. Java gezonden; ondanks den razenden spoed dezer commissie, bleeł zij een paar maanden bezig. Later werd er geklaagd, dat de rapporten dier Commissie 
niet onder Addison's nagelaten papieren te vinden waren. Proc. 28 Oct. 1814 werd hij lid van het Revenue Committee en den 22 Dec. 1814 bovendien Postmaster General, na de overplaatsing van W. Ainslie naar Samarang. In het laatst dier maand vergezelde hij Raffles op een kleinen kruistocht naar Straat Soenda, kreeg bij den terugkeer een nat pak, daarna koorts en overleed te Buitenz. 14 Jan. 1815. De Gazette van 21 Jan. bevatte eene korte necrologie, en in een brief van denzelfden datum aan het Opperbestuur werd hij door Raffles hoog geprezen. Men kan zijn graf vinden in den kleinen doodenakker dicht bij het paleis te Buitenzorg.

Addison (Robert), die te Bat. een winkel opende en met James Ainslie eene zaak opzette (Gaz. 5 Maart en 21 Mei 1814) was volgens Campbell (II, 929) zijn broer; later suikerfabrikant.

\section{Adimonggolo zie: Saleh.}

Affelen van Saemsfoort (C. H. J. van), geb. te Alphen, kwam op Java in 1802, bracht het onder Daendels tot Fiscaal der Houtbosschen, bleef bij de inneming van Batavia in strijd met Janssens' order aldaar vertoeven; wordt in Oct. 1811 benoemd tot Adjunct van Flint; Proc. 4 Jan. 1812 wordt hij diens second Assistant op 150 \$. In Maart 1812 vinden we hem te Indramajoe als hulp van den Resid. van Cheribon tegen Bagoes Rangin; Proc. 16 April 1812 wordt hij benoemd tot Opziener bij den wegaanleg van Tandjoengpoera naar Tjiasem; vraagt ontslag als zoodanig in Jan. 1813. Daarna vinden we hem als zakwarnèmmer te Samar.; de tuin enz., aan den Bodjongschen weg, dien hij in Gaz. 11 Dec. 1813 te koop biedt, zal wel zijn eigen niet zijn geweest. Een listig en brutaal heerschap, dat Proc. 1 Aug. 1814 zonder opgaaf van redenen gelast wordt naar Europa te vertrekken. Hij bood echter excuses aan en kreeg bij Proc. 28 Oct. 1814 uitstel; was bij Raffles' vertrek nog op Java. Overleed insolvent te Samarang 5 Juli 1820 oud 42 jaar.

Ainslic (Danicl), ook genoemd Doctor Ainslie, was Surgeon of the Horse Artillery te Madras geweest en met deze troepen naar Java gekomen. Den 19 Jan. 1812 teekent hij te Bat. een rapport als Acting Superintending Surgeon; maar in April van dat jaar schrijft Raffles aan Yule, dat Dr. Ainslie van Bantam met een rapport van dien Resident naar Bat. moet komen om hem in staat te stellen be- 
slissingen te nemen in zake den politieken toestand aldaar. Proc. 10 Oct. 1812 wordt hij benoemd tot Third Commissioner for settling the transferred districts der Vorstenlanden op 750 \$ p.m. Raffles verklaart hem Proc. ibid. voor a gentleman of high talents and abilities, maar Doeff verzekert (Herinneringen p. 219), dat zijne zucht tot den drank hem ,geheel ongeschikt tot alles" maakte. $\mathrm{Na}$ het overlijden van Hunter werd A., thans oudst aanwezend Medical officer, naar Bat. opgeroepen als waarnemend Superintending Surgeon (Gaz. 26 Dec. 1812); hij volgde dezen tevens op als Secretaris van het Bat. Genootsch. (Widow p. 610). Omstreeks 1 Juli 1813 vertrok hij met Wardenaar als Commissaris en ais Surgeon naar Japan, alwaar hij 4 maanden bleef (Verh. Bat. Gen. VIII, 87), waar hij. volgens Doeff, doorging voor een Amerikaansch dokter, en vanwaar hij, na door Doeff volkomen schaakmat gezet te zijn, 20 Dec. 1813 te Bat. terugkwam, op welken dag hij tevens zijn rapport indiende; hij had een voorraad tin voor eigen rekening naar Japan meegenomen en daarvoor koper gekocht, hetwelk de Regeer. voor 3795 Java Roep. van hem overnam. Hij presenteert 12 Dec. 1814 eene rekening van 22.000 Java Roep. voor persoonlijke en geheime uitgaven in verband met die reis, waartoe hij groote inkoopen had gedaan. Den 10 April 1814 vertrekt hij met Assey naar Bengalen en wel, zooals Assey in Proceed. 11 Maart 1816 schrijft, to explain the circumstances of the Japan adventure as might be required by the Supreme Govt. en keert met dezen 23 Sept. vandaar terug. Proc. 6 Dec. 1814 wordt hij benoemd tot Resident van Probolinggo en Political Agent with the states of Bali, welke laatste werkkring blijkens circulaire 15 Dec. ook omvatte the adjacent Islands. Diezelfde maand was hij te Boeleleng; eerst 7 Jan. 1815 nam hij de residentie Bezoeki en Prob. over van Davis en 13 Jan. van denzelfde the office of Collector of Revenue of these districts. Den 14 Juni 1815 vertrok hij naar Banjoewangi; hij keerde niet naar zijne residentie terug; bij schrijven van 3 Juli werden door de Regeer. Bima en Timor onder zijne immediate superintendence geplaatst (misschien in verband met de Tambora-uitbarsting). Proc. 10 Aug. 1815 werd hij benoemd tot Resident te Djokja; eerst 1 Nov. aanvaardde hij deze residentie, welke hij in verband met de Sepoy-samenzwering reeds 22 Jan. 1816 moest overgeven aan Crawfurd; onder het excuus van ziekte kreeg hij 3 maanden buitenlandsch verlof. In de zitting der Regeer. van 11 Maart 1816, den dag vóór Raffles' aftreding, wist Cranssen een voorstel van dezen te doen verwerpen, om aan 
Ainslie 15.000 Jav. Roep. te doen uitbetalen als secret service money, tijdens de reis naar Japan. Hij overleed te Weltevreden 22 Juli 1816. Kan moeielijk iemand van groote bekwaamheid geweest zijn. Dat de overigens nog al bezadigde Crawfurd zoo sputtert tegen Doeff (History III, 307), zal wel zijne verklaring vinden in Ainslie's qualiteit van Schot.

Ainslie (William), broeder van den voorgaande (denkelijk beiden Schotten; een James Ainslie van Montrose komt in Juni 1815 te Bat.), komt 25 Febr. 1814 uit Bengalen te Bat. Wordt Proc. 2 April 1814 benoemd tot Resident der Ommelanden, welke werkzaamheden hij 20 April overnam van Smissaert. Bij schrijven van 11 Juni 1814 benoemde de Regeer. hem bovendien zonder traktement tot Postmaster General; in die qualiteit werd hij den 1 Juli 1814 toegevoegd aan de rondreizende Commissie Bauer-Addison, speciaal ter regeling van de brievenposterij en ter opneming van den staat van wegen en bruggen. Niettemin bleef hij Resident der Ommelanden; als zoodanig schrijft hij derhalve nu eens uit Rustenburg of Kampong Makassar, dan weer uit Samarang of Soerabaja! Proc. 6 Dec. 1814 wordt hij benoemd tot Resident van Samarang; 12 Dec. neemt Van Doorninck de residentie der Ommelanden over by verbal orders of Mr. Raffles, doch Ainslie kon eerst 12 Jan. 1815 van Batavia vertrekken en neemt pas 16 Jan. de residentie Samarang over van Cotes. Hij werd bij Proc. 14 April 1815 begunstigd met een tafelgeld van 500 Rupees, ingaande met zijne ambtsaanvaarding, (doch verloor de posterijen, zie Addison). Wordt Proc. 10 Aug. 1815 benoemd tot Resident van Soerabaja en Bangkalan, maar geeft eerst 18 Sept. Samarang over aan Crawfurd om 21 Sept. Soerabaja over te nemen; blijkens Proc. 21 Juni 1816 ontdekte zijn opvolger te Samarang een groot kastekort. Bij schrijven der Regeer. van 18 Jan. 1816 werd ook the administration of the Revenue Department van Soerab. aan hem toevertrouwd.

De zonderlinge plaatsingen van dezen man trekken te meer het oog, omdat hij slechts Assistant Surgeon was, reden waarom Hartilieff, de Samarangsche pakhuismeester en gewezen officier, dezen Resident als zijn mindere verkoos te beschouwen.

Assey (Charles) was Surgeon van het 3d. Bengal Volunteer Battalion; werd Proc. 21 Oct. 1811 benoemd tot Assistant van den Civil Commissioner Hope te Samarang; hij trok als zoodanig 375 \$, 
en bleef op Java ook nadat een order uit Bengalen was gekomen, waarbij hij als Surgeon naar Ambon werd verplaatst. Bij schrijven van 13 Maart 1812 gaf Raffles aan Hope kennis, dat A. tijdelijk zou fungeeren als Deputy Civil Commissioner te Soerabaja, welke betrekking deze den 10 April van Gibbs overnam, zonder dat zulks echter eene vermeerdering van salaris meebracht, zoodat hij reeds 22 April ontslag vroeg, indien zijn traktement niet mocht worden verhoogd. Den 7 Juli 1812 kon hij zijne tijdelijke betrekking overgeven aan den Assistant Deputy Commissioner Captain Davy; hij keerde naar Samarang terug, waar Raffles toen was, die den 16 Juli 1812 vandaar schreef: „I have appointed $\mathrm{Mr}$. A. to be Assistant Secretary to Govt. and Secretary to the Lieut. Governor"; het salaris van 750 \$ zou ingaan met 1 Aug., met welken datum de twee betrekkingen van Assistant Secretary in het Public en het Secret Departm. zouden ophouden. Wegens de onbekwaamheid van Blagrave werd hij gaandeweg met diens werkzaamheden belast. Proc. 5 Jan. 1813 werd hij bovendien Editor of the Govt. Gazette (treedt af als zoodanig Proc. 16 Juni 1813); den 5 Dec. 1812 en 26 Febr. 1813 is hij ook waarnemend Assistant Secretary Military Dept. Proc. 12 Maart 1813 wordt hij benoemd tot Secretary to Government, retaining his office as Secretary to the Lieut. Governor; in zijne eerste qualiteit trok hij ingevolge Proc. 9 April 1813 per maand $1.000 \$$, in de tweede 375 ; wordt tevens lid van het Revenue Committee, Proc. 13 Aug. 1813. Dit laatste was eene onbezoldigde betrekking; de beide evengenoemde salarissen worden Proc. 30 Juni 1814 vermeld als van 2.000 en 1.000 Java Roep. Gedurende Raffles' reis over Java einde 1813 bleef A. te Buitenzorg. Hij woonde steeds ten paleize. In de vergadering der Regeer. van 16 Maart 1814 betoogde Raffles de noodzakelijkheid om A. naar Bengalen te zenden in verband met de weerlegging der aantijgingen van Gillespie; deze vertrekt daarheen dan ook 10 April met D. Ainslie; den 2 Juni arriveerden zij te Calcutta en den 23 Sept. kwamen zij terug. Volgens Van Deventer p. CXXVIII werd hij in Oct. 1814 met Bauer naar Bezoeki gezonden om een vergelijk te treffen met Han Tjan Pit. Bij Proc. 28 Oct. 1814 werd hij President eener commissie van rapporteurs over de public institutions te Bat. In Gaz. 19 Nov. 1814 lezen wij, dat hem verlof naar Europa is verleend voor particuliere aangelegenheden (zonder tijdsbepaling, mogelijk dus weer als agent van zijn patroon), doch het blijkt niet dat hiervan gebruik is gemaakt. Tijdens Raffles' reis over Java in 1815 is Assey te Bat.; Proc. 17 
Febr. 1815 blijkt hij met Robinson, Young en den waarnemenden Resident in eene Commissie voor de zaken der Ommelanden te zitten, waarmee zijne memorie over de Ommelanden dd. 12 Nov. 1815 samenhangt. Speciaal in verband hiermee en met de zaken der Weeskamer prijst Raffles hem Proc. 17 Nov. 1815 als een invaluable officer. Hij bleef verder op Java tot na het herstel van het Ned. gezag (als Secretaris der Britsche Commissarissen voor de overgave) en kwam anno 1819 Raffles nog te hulp in zijne aangelegenheden betreffende Singapore door het uitgeven eener brochure On the trade to China and the Indian Archipelago; with observations on the insecurity of the British interests in that quarter. Boulger (p. 239) noemt hem a most capable man; zie verder aldaar p. 274 en 163. Hij was steeds R.'s rechterhand; doch in de Gazette wordt hij nagenoeg nooit genoemd. Addison (p. 368) acht hem an excellent second to Mr. Raffles - quite as indefatigable and as capable.... uncommonly clever, quick and well-informed, algemeen geacht om zijn onafhankelijk karakter.

Van het boek, dat A. zou uitgeven over het Britsch bestuur over Java (Levyssohn Norman p. 320 noot 4) is op het Britsch Museum niets bekend.

Auchmuty (Sir Samuel), Lieut. General, Commander in Chief of His Majesty's and the Hon. Company's forces on the coast of Coromandel. Minto schrijft over hem (Minto in India p. 320): I have been most fortunate in Sir S. Auchmuty, not only as a General but as a gentleman. Collision (waar anders veel gevaar voor bestond, zie onder Gillespie) has been entirely excluded.

Bach (C.F.) was bij de verovering Scriba te Pekalongan; blijft claar vervolgens als Assistant to the Resident op 50 \$, denkelijk niets dan conmies.

Baker (G. P.), Lieutenant, daarna Captain; is Jan. 1812 te Samarang als Lieutenant commanding the 7 th company Bengal light inf. volunteer battalion (d.i. Sepoys); onderscheidt zich bij de verovering van den kraton van Djokja (Conquest p. 196); wordt 24 Oct. 1812 vermeld als geplaatst te Klaten; wordt bij Gaz. 11 Juni 1814 belast met het toezicht op de herstelling van the forts and public buildings in the Native provinces, vermoedelijk een baantje om hem eene geldelijke belooning te bezorgen voor diensten in het belang van het 
oudheidkundig onderzoek. In het voorjaar van 1815 begeleidt hij Raffles op diens reis (Widow p. 618); den 19 Mei 1815 schrijft deze hem, dat hij p.m. 500 Java Roep. zal trekken uit de kas te Solo als additional allowance during the period on which you may be engaged on the service directed by the Honble the Lieut. Gov.; bovendien bleef hij Superintendent of public works in the Native Princes' dominions. In de Java halfyearly Directory Juli-Dec. 1815 heet hij: Superintendent of public buildings Native Princes dominions; in het jaarboekje voor 1816 komt echter een captain Grant als zoodanig voor, en behoort Baker tot het garnizoen van Djokja, denkelijk in verband met de Sepoy-samenzwering, die had doen bespeuren, dat nagenoeg alle officieren van dezen troep afwezig waren. Zijne taak was in het bizonder geweest het in teekening brengen van Hindoe monumenten; onder hem werkte Knops, zie aldaar. Den 14 April 1816 (dus na het vertrek van Raffles) schrijft Baker uit Serondol aan den Resid. te Samarang over eene reis, door hem naar Solo gelaan ter controleering van Knops' teekenarbeid en over de alsnog door dezen te maken ,sketches”, indien I should travel this year. Raffles zegt (Hist. of Java II, 7), dat hij zich van B. bediende to survey, measure and take draughts of all the buildings, images and inscriptions van Prambanan; Baker diende daaromtrent ook een rapport in, waaruit duidelijk blijkt (ibid.) dat archeologie heelemaal zijn vak niet was: hij gebruikte een Sepoy om hem te verklaren wat hij zag; zie ook zijne verdere beschrijvingen van oudheden aldaar p. 12; $23 ; 24 ; 26$; p. 32 zegt Raffles, dat Baker op den Diëng drie weken heeft besteed aan het maken van een ,ground plan, as far as it could be ascertained, with sketches of the different images, ornaments and temples", en in zijne Discourse van 11 Sept. 1815 (Verh. B. G. VIII, 28), dat B. is now actively engaged in these pursuits, en wel dat hij reeds geleverd heeft the most accurate sketches of the present appearance of the most important of these ruins (op het eiland in 't algemeen) as well as ground plans and elevations of the principal temples with notices of much valuable information which is to be collected of their origin, object and history.

Bannisseht (J.C.von), een Duitscher, gewezen officier, was bij de verovering Opziener (2e klas) van Galoeh; wordt bij besluit van 2 April 1812 als zoodanig bevestigd, op 75 \$. Proc. 28 Mei 1813 heet hij Pakhuismeester op Noesakambangan. Hij werd 5 Febr. 1813 wegens vermindering van personeel ontslagen als Opziener, doch 
kreeg tegelijk het commando over de versterking bij de baai van Tjilatjap tegen de zeeroovers, waarmee wij hem in Oct. 1814 belast vinden.

Barrett $(W$.$) , een vriend van Raffles uit Penang, wordt 21$ Jan. 1812 lid van het Court of Requests te Bat. op 200 \$ en Proc. 14 Febr. 1812 Assistant Accountant op 250 \$. Trouwt 17 April 1812 met Jacoba Maria Goldman, dochter van J. C. Goldman, het eerste huwelijk van een Engelschman met een Hollandsch meisje na de verovering en als zoodanig eene groote gebeurtenis, die 26 Juni 1813 werd bezegeld door de geboorte van een zoon. Werd 13 Maart 1813 Civil Auditor; 28 Mei 1813 lid der Weeskamer op 150 \$ met uittreding uit het Court of Requests; ook de Weeskamer moest hij vaarwel zeggen, toen hij Proc. 1 Nov. 1813 werd benoemd tot Export and Import Warehousekeeper; hij bleef echter, als zijnde de eenige Engelschman met verstand van boekhouden, op het Accountant's kantoor als Civil Auditor werkzaam op 150 \$ en tevens lid van het Commercial Committee, hoewel Raffles Proc. 1 Dec. 1813 erkent, dat B. eigenlijk meer baantjes had dan één persoon kon waarnemen. Ondanks zijn pakhuismeesterschap, dat hem 1.320 Java Roep. p. m. aan salaris opbracht, bleef hij nog een uitgebreiden particulieren handel drijven, als agent van anderen of voor eigen rekening; de klachten der Regeer. daarover, 1 Mei 1814, leidden tot niets; zelfs werd hem bij schrijven van 30 Juni toegestaan, voorloopig niet den eed tegen particulieren handel af te leggen (een termijn werd niet bepaald) en zijn agentschap te blijven waarnemen. Zijn partner was J. Fichat, die zijn voorganger was geweest als Pakhuismeester, als zoodanig wegens knoeierij was afgezet en vervolgens Vice President der Weeskamer gemaakt. Barrett was steeds ziekelijk. Toen hij 8 Sept. 1814 overleed, bleek alras (Proc. 28 Oct. 1814), dat zijne boeken niet in orde waren en de vereischte borgtocht niet door hem was gesteld. De Accountant General rapporteert 24 Dec. 1814: The late import and export warehousekeeper Mr. Barrett has never delivered any accounts. Zijne particuliere zaken in Engeland, Bengalen en Java waren in 1822 nog steeds niet beredderd. Waarschijnlijk was Maria Henr. Francina Barrett van Poeloepinang, die 6 Juli 1823 te Bat. trouwt met Joh. Gerard Goldman van Samarang, zijne dochter. De weduwe Barrett hertrouwde in Nov. 1817 met J. I. van Sevenhoven.

Baud (J. C.), geb. te 's-Gravenhage 24 Oct. 1789. Uit Mr. P. D1. 92. 
Mijer, Jean Chrétien Baud geschetst, Utrecht 1878, blijkt, dat hij van vaders- en moederszijde van Fransche réfugiés afstamde. Leerde al in zijne jeugd Engelsch; had eene groote liefde voor den zeedienst en werd in 1804 kadet; in 1807 geplaatst op eene naar Java bestemde brik; bereikte echter Java niet, en keerde in 1810 na allerlei avonturen in Zuid- en Noord-Amerika naar Europa terug; gaat eindelijk samen met Janssens, tot wien hij door zijn vader eenige betrekking had en die hem aan boord als secretaris gebruikte, naar Indië; ook hier bleef hij diens particuliere secretaris; werd 1 Juni 1811 Tweede Commies; bij de verovering van Meester Cornelis vlucht hij naar Buitenzorg. Begeleidt Janssens op zijn verderen tocht, en komt zoo in kennis met Captain W. Robison (zie aldaar); krijgt door dezen, dank zij zijne degelijke kennis der Eng. taal, reeds in Oct. 1811 eene plaatsing op de Secretarie; 3 Juli 1812 vinden wij hem als First Assistant in het Translator's office en in Oct. 1812 als Dutch Translator op 200 \$; als zoodanig vervaardigde hij o.a. de Eng. vertaling der beschrijving van de in Krawang en de Preanger te verkoopen perceelen land. Proc. 9 April 1813 wordt zijn salaris als Second Assistant op het Secretary's office en Translator bepaald op 250 \$. Kort daarna valt (wat Mijer blijkbaar niet geweten heeft) zijn patroon Robison in ongenade; Baud ontwijkt den storm; maakt 26 Juli 1813 zijn testament (Notaris Piepers; zijn boedel beliep toen geen 2.000 Rds.) en vaart 6 Aug. 1813 als Supercarga op de Admiral Drury (reeders Timmerman Thijssen en Westermann) naar Macao met bestemming naar Kamschatka; keert reeds begin Jan. 1814 te Bat. terug van eene verloren reis. Wordt met ingang van 8 Febr. 1814 waarlijk weer benoemd tot First Assistant in the Secretary's office te Batavia op zijn vroeger salaris, hetwelk Proc. 30 Juni 1814 wordt vermeld als bedragende 550 Java Roep. Zijn werk was vooral het collationneeren en indexen der Proceedings; ook bleef hij steeds belast met vertaalwerk; zoo noodig verving hij den Secretaris; zijne bekwaamheid en ijver worden met lof vermeld. Hoe volkomen B. zich wist aan te passen, blijkt wel daaruit, dat zijn schrift sprekend is gaan lijken op dat van Assey en Raffles. Intusschen ziet men uit verschillende uitlatingen in zijne brieven, dat hij niets van het Engelsche bestuur moest hebben, of schoon hij in zijne nadagen, wanneer de liberalen hem het vuur aan zijne ministerieele beenen legden, soms beweerde (Mijer p. 97), dat hij onder Raffles vrijzinnige ideeën omtrent vooruitgang had ingezogen. B. was een opportunist, iemand die zijn levenshulkje met ongemeene handigheid wist te sturen. Had 
hij eertijds, in Noord-Amerika, niet naar Kentucky willen gaan omdat (Mijer p. 39) de roep der schoonheid van de Kentuckysche meisjes hem benauwd maakte voor een onberaden huwelijk (welk een zeeman van twintig jaar!), den 17 Aug. 1815 legde hij den grondslag voor zijne verdere carrière door zijn huwelijk met de zeventienjarige Wilhelmina Henrietta Senn van Basel, dochter van Mr. W. A. Senn van Basel en Theodora Jacoba van Riemsdijk, waardoor hij dus werd opgenomen in de clique der Riemsdijken, Engelhards en Sibergs, wier invloed na het te verwachten herstel van het Nederl. gezag zwaar zou wegen; voortaan (zie Van de Graaff I, 26) werd hij steeds conservatiever. Hij zelf placht te zeggen: „Mijn huwelijk bragt Gods zegen in mijn huis". Overigens een charmant jongmensch, wiens gezienheid ook daaruit blijkt, dat hij in 1815 Secretaris van de Harmonie was. Commissarissen-Generaal belastten hem al vóór de overname van het bestuur met zekere werkzaamheden; daarna werd hij terstond benoemd tot Secretaris van het Gouvernement en in 1819 (dus op 30-jarigen leeftijd) tot Algemeenen Secretaris. Met zijne verdere loopbaan behoeven wij ons hier niet in te laten. Op 24 Juli 1833 is hij, anderhalf jaar na den dood zijner vrouw, te Bat. hertrouwd met Ursula Susanna van Braam, wed. C. P. Jutting, dochter van Jacob Andries en Ambros. Wilhelm. van Rijck, geb. te Bat. 6 April 1801.

In den deftigen Mr. P. Mijer (het boek van dezen Oud-Minister en Oud-Gouvern.-Generaal had even goed kunnen zijn geschreven door een Hoofdcommies) heeft Baud een biograaf gevonden, die alle scherpe kanten zorgvuldig heeft weggeschaafd. Volgens Mijer heeft B. nooit eene dwaasheid, nooit zelfs eene fout begaan, nooit iets als geestdrift of hartstocht gekend. Wat hier vooral de aandacht verdient, is, dat Levyssohn Norman bij het schrijven zijner schitterende en nog steeds gezaghebbende dissertatie over het Engelsch bestuur op Java uit Baud's mond onder meer de uitspraak (zie bij hem bl. 182) moet hebben opgevangen en wat te haastig overgenomen, dat de liberale beginselen, door dat bestuur verkondigd, niet veel anders zijn geweest dan een ,papieren sluijer” voor wanbeheer, iets wat uit de door Levyssohn Norman gebruikte officieele stukken (dat is dus den ,papieren sluijer” zelven) niet kon blijken en te beschouwen is als de korte inhoud van zijne gesprekken met den Oud-Minister.

Bauer (J. J. A. G.), geb. 1767 in Silezië, kwam op Java als soldaat 1786, bracht het onder Daendels tot President der Rekenkamer. 
Biographie van hem in Priangan I, 129 e.v. Den 6 Nov. 1811 meldt hij zelf naar Samarang zijne benoeming ,tot eerste Gouvernements Accountant of eygenlijk tot Visitateur en Boekhouder Generaal" (een bewijs, dat hij wilde boekhouden op de oude manier der O.-I. Compagnie, namelijk residentiegewijs). $\mathrm{Hij}$ is Accountant General and Auditor gebleven tot de teruggave; in 1811 was zijn salaris 500 \$; in 1812 werd het 750 \$, in 1814 Java Roep. 1.650; bij publicatie van 28 Mei 1813 werd hij ook lid van het Revenue Committee; volgens Gaz. 21 Mei 1814 bovendien Superintendent der Native Orphan Chamber. Den 1 Juli 1814 werd hij met Addison in commissie gesteld om bezuinigingen in te voeren op eene reis over Java. Bij Raffles, die zulk droog werk als financieele contrôle gaarne overliet, stond hij steeds in hooge gunst; Proc. 10 Oct. 1812 roemt R. zijne superior talents and integrity; Proc. 4 Mei 1813 krijgt hij den dank der Regeer. voor zijne toewijding; in een schrijven der Regeer. aan het Opperbestuur (Proc. 28 Mei 1813) evenzoo. Toen dit laatste, dat zeer weinig met zijne gestie was ingenomen en voortdurend aanmerkingen maakte (waarop B. een zijner slaven den naam .,Geduld or Moira” gaf) van plan bleek om een vervanger uit Bengalen te zenden, roemde Raffles Proc. 2 Febr. 1816 wederom B.'s uitstekende bekwaamheid. Als B. dan ook Proc. 1 Dec. 1813 verklaart: „It is not only disagreeable but dangerous also to hold my situation" (zijn Deputy Buijs te Soerab. had onlangs een formidabel pak ransel gekregen van den Pakhuismeester aldaar), verklaart Raffles dat hij hem bij zal staan. Toen deze laatste was heengegaan, kreeg B. van het afgetreden Eng. bestuur in Mei 1817 klachten te hooren over zijne slordigheid en traagheid, zie Van der Kemp, N.-I. Bestuur p. 356; zijn verweer ibid. p. 360 e.v. Van de Graaff had geen hoog idee van B.'s bekwaamheid (Brieven II, 215; zie ook aldaar p. 135). Men vergelijke vooral het rapport van den Accountant General te Calcutta (in Proc. 1 Jan. 1816) over B.'s begrooting voor 1812/3.

Terwijl hij in 1812 een translateur gebruikte voor zijne Eng. correspondentie, bewijzen talrijke eigenhandige brieven, dat hij in 1815 goed Engelsch geleerd had. Eigenaardig is, dat bij hem in April 1814 ook de zorg berust voor de in het Gouv, huis op. Molenvliet (waar ook de Accountant zetelde) opgeborgen „Dutch records” d.i. het Compagniesarchief. Overlijdt als Pres. der Rekenkamer 16 Aug. 1823. Zijne graftombe is op Tanahabang nog te vinden. 
Beauregard $(J . R . d e)$ wordt bij General Orders van 22 Oct. 1812, zijnde Lieutenant Bengal Native Infantry, benoemd tot Commandant der Djajang Sekars in Cheribon; bij schrijven van 15 Juli 1813 bericht de Regeer. aan belanghebbenden, dat hij (thans Captain) is benoemd tot Assistant to the Resident at Paccalongan op 150 \$. In die qualiteit teekent hij zich nu eens Ass. to the Resident, dan weder Assistant Resident. Bij schrijven van 27 Dec. 1813 wordt zijn salaris gebracht op 300 \$, ingaand 1 Jan. a.s. Bij schrijven van 20 Juli 1815 erlangde hij op verzoek ontslag als Assistant to the Res. of Pacc. onder dankbetuiging; komt 1 Aug. 1815 met zijn gezin te Batavia; blijkens Proc. 10 Aug. 1815 vertrok hij na daartoe bekomen verlof van het Opperbestuur naar Europa, en wel, blijkens de Gaz., op 16 Sept. 1815. Over een loor hem te huren land zie onder: Winckelmann.

Beetjes (P. J.); mededeelingen omtrent hem in Priangan IV p. 719 noot. Geboren te Samarang; leerling der Marineschool aldaar; legde 1797 het eindexamen af en werd onderwijzer bij die inrichting. Was bij de verovering Luit.-Kolonel der genie. De architect Jongkind noemt hem 12 Nov. 1812 one of my best and most efficient assistants; hij zou toen op reis voor de opneming der in de Preanger en Krawang te verkoopen perceelen Gouv. land; Proc. 18 April 1816 wordt dan ook vermeld, dat hij vroeger het heele land Goenoengparang heeft opgemeten as well as the regency of Chianjore. Nov. 1813 heet hij ,waarneemend Landmeeter” te Bat.; April 1814 is hij Surveyor in de Preanger op 220 Java Roep. Proc. 13 Mei 1815 blijkt, dat hij eene kaart en statistical tables van dat gewest heeft vervaardigd; zijn salaris van 100 \$ wordt verhoogd tot $150 \$$, ingaande 1 Jan. 1.1.; hij moet thans naar Cheribon om dit op te nemen. Over de voltooiing zijner kaart van de Preanger en Krawang spreekt Proc. 27 Oct. 1815. Den 24 April 1816 schrijft de Resid. van Cher., dat B. zijn gewest heeft verlaten en weer in de Preanger werkzaam is. Van Waeij (wiens vader Hendrik Willem van Waeij, eerst leerling, daarna Tweede en vervolgens Eerste Informator en Directeur der Marineschool, getrouwd was met eene zuster van Beetjes, genoemd Maria Petronelle Beetjes; deze M. P. van Waeij-Beetjes woont 1820 te Batavia, en overlijdt te Samarang 20 Sept. 1842, oud 72 jaar) schrijft dan ook, dat B. ,de Preanger Regentsch. met inbegrip van Crawang en Indramaijo zoomede de residentie Cheribon topogra- 
phisch opgemeten en in kaart gebracht heeft". Sneuvelde op Saparoea 1817 .

Beusechom (J.M.van), geb. te Schiedam 1775 (zijne moeder was eene Van Polanen en hij was een neef van den bekenden Mr. R. G. van Polanen; zal ook verwant zijn geweest aan L. A. J. Petel, die de man was van Sara Johanna van Polanen), kwam op Java Aug. 1799 als supercarga op een Amerik. schip en ging over in den dienst der Comp. als Boekhouder; trouwde in 1803 met Adriana Henrietta Louisa van Riemsdijk, en was bij de verovering Shahbandar en Licentmeester; Van Polanen noemt hem verkwistend (Dr. de Roo I, 110). $\mathrm{Na}$ de komst der Eng. was het met zijne grootheid uit. In 1812 ontmoeten we hem op 250 \$ als Dutch registrar bij de Secretarie, dus belast met het archief dat (na de verzameling door Van Boeckholtz en Lippe) Proc. 18 Nov. 1812 onder zijn beheer was gesteld; als lid van het College van Curatoren (Proc. 15 Sept. 1812) trok hij niets. De betrekking van Dutch Registrar werd opgeheven bij publicatie van 28 Mei 1813, terwijl de archieven toen conform de Proceed. van dien dag werden gesteld partly under charge of the Accountant (sic) and partly in the office of the Secretary to Govt. Proc. 23 Juni 1813 wordt hij op het zelfde salaris van 250 \$ Salt-agent in the Western Districts; na herhaalde klachten van Macquoid over zijne slordigheid (Proc. 1 Aug., 28 Oct. 1814) werd hij eerst geschorst en daarna (Proc. 11 Nov. 1814) op verzoek ontslagen. Den 28 Aug. 1815 werd hij lid der Weeskamer, een erg bescheiden baantje voor iemand met zijne connecties. Van zijn schoonvader erfde hij Tjimanggis. Hij overleed te Bat. 14 Maart 1847 oud 71; zijne vrouw A. H. L. van Riemsdijk overleefde hem.

Bidwell $(W$.$) komt in de Gaz. van 27$ Juni 1812 voor als Lieutenant Bengal Volunteers. Den 18 Jan. 1816 gelastte Raffles, te Samarang zijnde, hem om de residentie Samarang over te nemen van Crawfurd, als waarnemend Resident, ,provided the same does not interfere with your military duties"; hij zou tevens zijn Assistant in the Revenue Dept. en zijn salaris 800 Java Roep. Hij nam de residentie over den 20 Jan.; den 31 Jan. van Burney het Revenue Dept., doch trad in deze laatste betrekking eerst 6 Febr. op. Den 7 Mei 1816 gaf hij de residentie Samarang over aan W. Boggie, waarop hij verzoekt te worden ontheven from the appointment as Assistant in the Revenue Dept., (welke latste betrekking door de Regeer. in ver- 
band hiermee wordt aangeduid als die van Assistant Resident). Dit betrof denkelijk de van Captain D. Macleod omstreeks half April 1816 overgenomen functies.

Bingley. (Thomas) stond vermoedelijk in persoonlijke betrekking tot Raffles, wiens vader een scheepskapitein was geweest en wiens naam voluit luidde: Thomas Stamford Bingley Raffles, naar een Mr. Bingley of London, die zijn doopvader was geweest (Boulger p. 1; Egerton p. 2). Onze B. dateert dan ook 19 Juni 1813 een brief „Government House Ryswick”, d.i. ten huize van Raffles, het tegenwoordige Hotel der Nederlanden. Proc. 17 Oct. 1812 wordt gecreëerd de betrekking van Superintendent of Tonnage and Cargoes met een salaris van $500 \$$ en daartoe benoemd Thomas B., die dus vermoedelijk zeeman was evenals Raffles' vader; zoo zit hij Proc. 9 April 1813 in eene commissie tot keuring van een in te huren schip. Naar den datum te oordeelen, zou deze persoon dus uit Engeland kunnen zijn overgekomen, zoodra hij vernomen had, wie Lieut. Gov. van Java was geworden. Bij publicatie van 28 Mei 1813 wordt evengenoemde betrekking afgeschaft en B. benoemd tot VicePresident der Weeskamer; als zoodanig trok hij hetzelfde salaris. Blijkens de Gaz. overleed hij 20 Aug. 1813 at the Government House at Buitenzorg; hij heet hier (28 Aug.) free merchant and Vice Pres. of the Orphan Chamber at Bat., eene zonderlinge combinatie van qualiteiten. Zijn grafsteen ligt in het begraafplaatsje in den Buitenzorgschen tuin.

Blagrave $(C . G$.), een young man, zooals Raffles hem ergens noemt, komt 1 Dec. 1811 met zijne vrouw (van zichzelve Jane Colvin) en bedienden van Malakka te Bat. Proc. 10 April 1812 leest men: „Mr. Blagrave of the Bengal Civil Service having tendered his services to this Govt. and the scason of the year not affording the probability of his reaching Amboina before the change of the monsoon" (hij was namelijk bestemd geweest voor Second Assistant to the Resident aldaar) wordt nu provisioneel benoemd tot Secretary to Govt. op een salaris van $400 \$$ meer dan hij op Ambon zou hebben genoten, welk laatste salaris 600 \$ bedroeg (Proc. 14 Mei 1813). Bovendien kreeg hij in Nov. 1812 nog $100 \$$ huishuur. Zijn titel was Acting Secretary to Govt. (soms ook, Proc. 10 Aug. 1812, English Secret. to Govt.). Hij kreeg zijn ontslag als zoodanig den 12 Maart 1813, en wel, blijkens Proc. 14 Mei 1813, tengevolge van een verbod 
van het Supreme Govt. om te Bat. ambtenaren aan te houden, die voor de Molukken bestemd waren; maar inderdaad, zooals $\mathrm{R}$. later beweerde, om zijne onbekwaamheid, zijne loslippigheid, zijne afkeuring van genomen maatregelen (zooals den landverkoop) en zijn steunen van Gillespie. Hij bleef echter te Bat. hangen en toonde zijne ontevredenheid over zijn ontslag; dit noopte de Regeering tot tegenmanoeuvres. Proc. 14 Mei 1813 komt in behandeling een in Juni 1812 door B. tegen den raad van Raffles gedane aankoop van een Comps. vaartuig, hetwelk hij, zonder het te hebben betaald, daarna onder een anderen naam aan de Regeer. verhuurde, die hem tot de betaling noodzaakte, doch over het bedrag ruzie met hem kreeg. Later bleek bovendien (Proc. 2 April 1814), dat B. de notulen der Regeer. betreffende dien verkoop en die verhuring had vervalscht. Bauer spreekt ergens van ,de losheijd waarmede de Heer B. de publicque zaaken behandelde". Men krijgt echter den indruk, dat Raffles om andere redenen de zonden van B. zoo breed mogelijk uitmat. Hij vertrok begin Mei 1813 naar Bengalen (zijne vrouw ging eerst 16 Oct., samen met Gillespie); in de Gaz. van 10 Juni 1815 kan men lezen, dat hij aldaar werd benoemd tot Collector of Rungpore. Hij was niet als aanklager van $\mathrm{R}$. opgetreden, doch na de aanklacht door Gillespie werd 1 Jan. 1814 Blagrave om opheldering gevraagd; deze gaf hij in een voor R. ongunstigen zin, doch zoo, dat zijne verregaande onkunde al spoedig aan den dag moest treden. Over hem zie Levyssohn Norman p. 301 i. f.; Boulger p. 237; 238.

Blocm Rzn. $(W$.), gewezen Resident te Bandjarmasin, 1798 en 1803 , wordt 12 Oct. 1811 gelast van rapport te dienen over de mogelijkheid enz. van eene nieuwe vestiging aldaar; wordt 15 Dec. 1811 op verzoek ontslagen als Scriba te Tegal, wat hij sedert 1809 was, maar bij publicatie van 21 Jan. 1812 benoemd tot Baljuw te Samarang; wordt Proc. 4 Oct. 1812 als Baljuw en Waterfiscaal te Samar. wegens afpersingen geschorst, doch Proc. 22 Jan. 1813 van schuld vrijgekend en benoembaar verklaard tot openbare ambten. Bij schrijven van Raffles dd. 27 Dec. 1813 benoemd tot Resident te Pontianak, ondergeschikt aan Hare; ,you are not restricted from trade on your own account", heet het daarbij. Den 29 April 1815 ontving hij den last om vandaar op te breken, hetgeen reeds bij schrijven van 28 Mei 1814 door het Opperbestuur was bevolen; hij bleef er voor zijne persoonlijke belangen echter nog eenige maanden en arriveerde eerst 19 Oct. 1815 te Samarang; was einde 1816 Resi- 
dent van Tegal. Blijkens de handteekeningen onder bewaarde brieven is deze Bloem dezelfde leuterkous, die Baljuw te Samar. was geweest; deze Willem Bloem R.z., gehuwd met D. A. van Rijck, overlijdt te Samarang 9 Mei 1820 als Lid van den Raad van Justitie ; ,wijlen de Wel Edele Hr. Wm. Bloemcs (sic)”, die insolvent was overleden, vermeld in eene advert. in Gaz. 18 Febr. 1815, zal dus een ander moeten zijn.

Blomhoff (J. Cock), Pakhuismeester op Decima (alwaar hij 28 Juli 1809 was verschenen, zie Doeff, Herinneringen bl. 176) komt 20 Dec. 1813 met Wardenaar en D. Ainslie uit Japan te Bat. terug en wel (Doeff p. 212) als gemachtigde van Doeff en door dezen ,onder goedkeuring mijner wettige gebieders” tot provisioneel Opperhoofd benoemd, met diens instructie om te bewerken dat Raffles hem Doeff zou erkennen als Opperhoofd, en om dan met dezen eene „overeenkomst” te sluiten aangaande den handel op Japan (een zeldzaam brutaal stukje!). In April 1814 weigert hij inlichtingen te geven aangaande den Jap. handel, tenzij het Gouv. hem erkent als zaakgelastigde van Doeff en bedoelde overeenkomst met hem aangaat. Den 5 Juli 1814 schrijft N. Engelhard aan een verwant in Nederl. dat C. B. door Doeff naar Bat. is gezonden ,,voorzien met zijn instructie en teevens van een plan om op eene secuure voet den handel op Japan te continueeren op de bij de Hollanders g'usiteerde voet en onder Hollandsche vlag"; dat Raffles daar woedend over is, ,als zeeker stellende dat, Japan onder de capitulatie van het eijland Java begreepen zijnde, men de beveelen van hier had behooren te gehoorzamen. Men heeft al het mogelijke aangewend de Heer Bloemhoff daarvan te overreeden, dan hij is onverzettelijk in zijn stuk gebleeven en zig blijven beroepen op zijne instructie en daarvan niet te konnen afweiken. Het is niet te beslissen, waarover het Gouvernement meer gepiecqueerd is, of over de stijfhoofdigheid van de Heer B. of over de stoute taal, waarmede hij de belangens van de Hollanders in het rijk van Japan heeft gediffendeert”; tenslotte is hij ,ontboden in de vergadering van de Hooge Regeering, alwaar hem door de Heer Cranssen eenige vragen gedaan zijn, die hij alle volgens zijne principes heeft opgelost, dan, niet voldoende voor het Gouv. bevonden zijnde, heeft men hem civiliter arrest gegeven aan huis van de Balljuw buiten acces, en naar veerthien dagen aldaar te hebben doorgebragt, gaat hij nu met eene van de schepen over naar Engeland om volgens certeparthij in de kuijl gelogeerd te worden, waarvoor echter door 
zijne vrienden gezorgd is, en hij zal dus aan boord eene goede behandeling ondervinden". Maar 13 Juli 1814 schrijft Dupuy op last van Raffles aan C. B., dat hij zal gaan als prisoner of war en wel in consideration of your situation in life and the difficulty you would experience in providing accommodation for yourself on the passage to England; deze wijze van reizen will entitle you to proper accommodation. Evenzoo schrijft de Regeer. op dienzelfden dag aan het Opperbestuur (zie Proc. 1 Aug. 1814) bijna in dezelfde bewoordingen: deze qualiteit van krijgsgevangene will entitle him to proper accommodation on board during the voyage and the Commander has received the established allowance. Ook blijkt van eene vergunning om een inl. bediende mee te nemen. Zoodat dus het gangbare verhaal, alsof het eene laagheid van Raffles was om hem als krijgsgevangene te verzenden (ook bij Van der Kemp, Teruggave p. 209; 210), den bal misslaat. De Gaz. zegt 23 Juli 1814, dat hij gaat als prisoner of war; in het nummer van 13 Aug. 1814 staat hij onder de passengers. Zoo gelast 4 Aug. 1812 Raffles uit Salatiga om te zorgen voor de passage van het gezin van Gaudin (over wien zie Priangan III p. 587) naar Bengalen; de vrouw zal daarbij ontvangen the established allowance for prisoners of war in her situation. $\mathrm{Nu}$ was Gaudin zelf heel geen prisoner of war geweest, want hij was niet op Java toen dit veroverd werd; die ,opzending” naar Bengalen was dus eene gunst en eene vrij dure gunst ook. Uit testament Drost 24 Juni 1817 no. 10408 blijkt, dat B.'s echtgenoote was Titia Bergsma; hij was destijds geëligeerd Opperhoofd van Japan, vanwaar hij pas in 1823 terugkwam. Repatrieerde in 1824. Woonde later op Birkhoven bij Amersfoort (in de buurt van Andries de Wilde dus) met eene Japansche dame, zooals het heet, van hooge geboorte. Aangezien op Decima alleen Japansche lichtekooien mochten komen, lijkt ons die hooge geboorte wel wat verdacht.

Blommestein (D. C. van), geb. te Delft 1787, komt op Java in 1807, is bij de verovering Adjunct bij den Hoofdadministrateur van het Departement Batavia; wordt 18 Sept. 1811 provisioneel Drost der Bat. Ommel.; wordt 21 Jan. 1812 Deputy Fiscal bij het Supreme Court; Proc. 18 Nov. 1812 wordt aangeteekend, dat Raffles hem heeft benoemd tot Baljuw te Samar. op 200 \$. In Dec. 1814 is hij aldaar waarnemend Magistraat; in Juni 1816 Baljuw, Assistant in the police department en lid van het Court of Requests. Trouwde te Bat. 18 Oct. 1812 met Jos. S. Chr. M. Roubaud van Isle de 
France. Hij wordt 1819 Ommegaand Rechter te Samarang en overleed 10 Juli 1823. (Een W. van Blommestein trouwde J. C. A. van Braam).

Boeckholtz (J. D. J. d'Arnaud van); volgens Van der Kemp in Bijdr. 1898 p. 66, 135, was hij de zoon van F. van Boeckholtz, die onder de Comp. Tweede Resid. te Solo is geweest. Te noteeren valt daarbij, dat die vader, toen hij als Luitenant te Salatiga lag reeds vóór 1785 , zonder echter verstand van archeologie te hebben, teekeningen van Hindoe-oudheden benevens een beeld had gezonden aan het Batav. Genootschap; zie Bijdr. 1902 p. 582. De zoon was bij de verovering Eerste Commies bij den Secret.-Generaal L. W. Meijer. Nadat conform eene publicatie van 12 Oct. 1811 alle archieven waren samengebracht op het Gouv. huis op Molenvliet, werden den 22 Oct. Van Boeckholtz en B. Lippe (bij de verovering Eerst gezworen klerk ter Generale Secretarie) in commissie gesteld (onder toezicht van de English en Dutch Secretaries) to collect and register for the information and use of Government all public archives and records, plans, surveys and other public documents in the hands of the different Departments of the former Government and all persons in charge of such public documents, records etc. under the former Government have been required to give an account upon oath before this Commission of whatever was under their charge or administration and to give every information respecting the same that may be required (aldus Proc. 1 Nov. 1811, waar tevens Mackenzie's bemoeiing daarmee wordt genoteerd, en dat aan Muntinghe en Cranssen is verzocht alternately to preside over this Commission). Bij besluit van 1 Nov. 1811 wordt hij benoemd tot Adjunct Secretaris-Generaal; in eene kennisgeving van 28 Nov. 1811 leest men, dat hij gedurende de afwezigheid van L. W. Meijer zou fungeeren als Hollandsch Secretaris van het Gouvt. Hij teekent vóór dien datum dan ook als Assistant Secr. en daarna als Waarnemend Secr., hetgeen hij verscheidene maanden gebleven schijnt. Den 22 Aug. 1812 bevindt hij zich te Samarang. Later in 1812 en 1813 heet hij Dutch Assistant op het bureau van den Lieut. Gov. op 250 \$, of (Proc. 28 Mei 1813) of, het bureau van den Secretary. Zoo stelde hij in het Nederl. de marginale dispositiën op, welke er vielen op de in het Nederl. gestelde brieven en vonnissen der Raden van Justitie te Sam. en Soerab. Moesten er Ned. stukken in het Eng. worden vertaald, dan vertaalde v. B. ze eerst in het Fransch en daarna een Engelschman ze in 
het Engelsch. De Van Boeckholtz die 7 Dec. 1813 te Samarang aan Raffles Fransche vertalingen zond van Javaansche stukken, was hij; en ik geloof dat hij de Dutch Secretary was, die volgens Addison (p. 369) tot de vaste omgeving van Raffles in 1814 behoorde en ten paleize Buitenz. woonachtig was. Ook was hij denkelijk de gentleman of my family (d.i. dagelijksche omgeving), die Raffles hielp bij de vertaling der Brata Joeda (History I, 410). Proc. 30 Juni 1814 vinden we hem als Dutch and English translator op 600 Java Roep. werkzaam op het Javanese translator's office te Buitenz. Proc. 28 Oct. 1814 wordt hij belast met de waarneming der betrekking van den geschorsten Zoutagent van Beusechem; Proc. 6 Dec. 1814 wordt hij vast aangesteld tot Zoutagent in the Western Districts. Intusschen bleef hij bij voortduring translator in the office at Buitenz., als hoedanig hij 15 April 1816 (na Raffles' vertrek) ontslag vraagt. Gedurende Methven's reis over Java in 1815 met Raffles trad Van B. als zijn vervanger op als Assistant to the Res. of Buitenzorg (Gaz. Extrao. 25 April 1815).

Een G. F. d'Arnaud van B. was in 1815 klerk bij den Resident te Buitenzorg, daarna zoutpakhuismeerster aldaar; een $F$. van $B$. wordt bij een schrijven van 13 April 1816 aangewezen als Opziener van Soekapoera.

Boggie $(W$.). Bij Proceed. 16 Nov. 1811 wordt hem, zijnde Pakhuismeester, toegelegd 500 Rupees p.m. ,during the time he had the opium under charge, being from the 31th of August to the 24th Oct." Den 11 Dec. 1811 zond Hope eene anschrijving aan den Hoofdadministrateur van Java's N. O.-Kust, dat diens betrekking met den 15en zou ophouden en dat B. van dien datum af zou ,gechargeerd zijn met de pakhuizen alsmede met de uitbetaling der civilen en de collection of customs enz." Blijkens Proc. 4 Jan. 1812 trok hij als Deputy Collector of Customs $250 \$$ en als Gov. Storekeeper and Civil Paymaster 200 \$. Hij was echter voortdurend ziek en wordt Proc. 9 April 1813 vervangen als Storekeeper and Civil Paymaster, waarbij zijn salaris als Dep. Collector wordt gebracht op 350 \$ (daarentegen lezen we Proc. 28 Mei 1813, dat dit laatste $300 \$$ bedraagt). Bovendien was hij onbezoldigd lid van het Samarangsche Court of Requests, van welk baantje hij vergeefs trachtte ontslagen te raken. In blakende gunst stond Boggie blijkbaar niet; zoo wordt in Juni 1813 genoteerd, dat hij de pakhuizen onder zijn beheer zonder verificatie aan zijn opvolger had overgegeven. Proc. 
22 Oct. 1813 krijgt hij op verzoek wegens ziekte 3 maanden verlof met behoud van twee derde van zijn salaris; hij vertrekt 3 Nov. naar Banka en reisde zoo door naar Calcutta, van waar hij eerst 16 Sept. 1814 te Bat. terugkwam. Bij Proc. 14 Oct. 1814 werd hem gelast naar Sam. te gaan om zijn werk weer op te vatten. Blijkens Proc. 30 Mei 1814 en 18 Jan. 1815 had de G.-G. zijn verlof verlengd, hem een voorschot van 5.000 Sicca Rupees gegeven en zijn verzoek om boven zijn traktement als Deputy Collector met percenten te worden begunstigd, overgewezen naar Batavia. Nauwelijks op Java terug, ging hij weer requestreeren om meer inkomsten, waarop Raffles hem voor de voeten wierp, dat hij in het publiek op de Regeer. had afgegeven, hetgeen ten gevolge had, lat B., zonder zijne betrekking te Samar. weer te hebben opgevat, den 25 Oct. 1814 ontslag verzocht, dat hem Proc. 1 Nov. werd verleend; naar rekesten van hem, om de tegen hem gerezen klachten te onderzoeken, werd niet geluisterd (uit brieven in Proc. 25 Nov. 1814, waarin hem de eisch werd gesteld te bewijzen dat hij het Gouv. welgezind was, krijgt men den indruk, dat Raffles hem wel wilde helpen, als hij zich maar partij stelde tegen Gillespie), waarop hij 19 Dec. 1814 verlof vroeg, on naar Bengalen te gaan om te klagen; dit werd toegestaan en 23 Jan. 1815 verliet hij Bat. opnieuw. Blijkens Proc. 17 Febr. 1815 had hij te Samarang als Dep. Collector alles samen wel 1.000 Ropijen p. m. getrokken. Den 11 Maart $1816 \mathrm{zag}$ men hem te Bat. terugkomen samen met Fendall en Abraham. Zijn eerste werk was weer een request, waarin hij verklaarde, dat Raffles hem had beschuldigd te Calcutta tegen hem te hebben geintrigeerd met de medestanders van Gillespie. Proc. 6 April 1816 wordt hij benoemd tot Resident van Samarang, welke residentie hij den $7 \mathrm{Mei}$ van Bidwell overnam. Deze betrekking bleef hij bekleeden, tot hij 17 Aug. de residentie overgaf aan H. A. Parvé; onderwijl was hij op eigen gezag eens naar Bat. gereisd om den Lt. Gov. te spreken. Zijn bestuur kenmerkte zich door akelige standjes met den Regent van Samarang en diens zoons, protégés van Raffles, speciaal naar aanleiding van den afstand door dezen aan den Regent van een deel van Bodjong (Pragata), als zijnde dit een familiegraf. Met groote ruwheid, met razen en tieren, heet de Regent in het publiek door B. bejegend te zijn; op den aloenaloen werd deze gedwongen zijne kris af te geven en in arrest naar huis te gaan; éen familielid kreeg klappen met een sabel en de kleeren werden hem van 't lijf gerukt; hoofden werden in de gevangenis gestopt en de heerendiensten weder danig ingescherpt. Ook 
Crawfurd, die later deze zaken moest onderzoeken, kreeg van B. een alleronbeschoftsten brief. Zijn haat tegen Raffles werd door Fendall benut, door hem een onderzoek op te dragen naar de Bandjarmasinsche zaken, welke hem stof leverden tot een pamflet, dat later door Baud gebruikt is voor zijn opstel dienaangaande; zie Van der Kemp in Bijdr. 1898 p. 5 en 44 i. f.; Herstel p. 251; 375 noot 2; N. I. Bestuur 90.

Bois $(G$.$) , geb. te Cheribon, was bij de verovering Opziener in de$ Cher. Sultanslanden; wordt 2 April 1812 Koffieopziener 1e klas op 100 \$, welk salaris 2 Juli 1812 wordt gebracht op 150 \$, naar aanleiding van de door hem verrichte arrestatie van Bagoes Rangin op 27 Juni. Proc. 17 Sept. 1813 wordt hij echter, zijnde gewezen Opziener (de betrekking was opgeheven met de intrekking der cultuur in 1813) benoemd tot landmeter in Cher. op 100 \$; in Aug. 1814 schrijft de Regeering dat, nu het detailed system of land revenue in Cher. zal worden ingevoerd, hij als landmeter moet worden vervangen. Den 20 Juni 1815 schrijft de Resident, dat hij als Subcollector is geschorst; er had toen een onderzoek plaats, waarbij heel wonderlijke dingen aan het licht kwamen: B. leefde met de weduwe van Bagoes Rangin, placht op heilige plaatsen te bidden om Resident van Cherib. te worden, had zich bij den aanslag der landrente aan grove knoeierijen schuldig gemaakt enz. Hij wordt nu Proc. 9 Oct. 1815 ontslagen, met last om binnen 3 maanden Cherib. te verlaten; in Dec. 1815 daarentegen werd hem verboden de hoofdplaats Cher. te verlaten, ofschoon hij een huis had te Radjagaloeh, dat de Regeer. van hem overnam. In April 1816 wordt hij door den Resid. beschreven als a lowbred unprincipled fellow, die alles had opgeofferd aan the vanity of exhibiting a splendid rent roll; de heele administratie der landrente was in zijne handen geweest en hij had maar lukraak aangeslagen, veel te hoog. Zijn opvolger als Subcollector op 300 Java Roep. wordt 20 Jan. 1816 een J. H. Heidenreich (van Amsterdam, 1802 op Java gekomen, thans burger te Cheribon).

Bolton $(G$.$) , Lieutenant, neemt deel aan de verovering van Sambas,$ Juni 1813; komt 14 Mei 1814 te Bat.; neemt in Juni 1814 deel aan de operaties tegen Boni; wordt 20 Jan. 1816 benoemd tot Assistant van den Res. van Cherib.; arriveert aldaar 29 Jan. Maar reeds 7 Maart 1816 komt Dillon er als zoodanig. 
Borwater (J. C.) van Leiden was bij de verovering woonachtig te Solo als leerling in de Javaansche taal (eene instelling van Janssens, 20 Juli 1811); hij werd echter wegens wangedrag naar Samarang gezonden, waar hij in Nov. 1812 en nog in 1814 als student of Javanese language op $22 \$$ op het residentiekantoor werkte ,to exercise himself in this language". Later hoort men niet meer van hem.

Boswel (J.C.) van Amsterdam was bij de verovering Oud-Schepen titulair te Bat. en Notaris buiten de stad; 10 Sept. 1811 op verzoek als zoodanig ontslagen; wordt 21 Jan. 1812 Member of the Bench of Magistrates, doch reeds in April op verzoek ontslagen; Proc. 13 Mei 1812 Superintendent Vendu Dept.; 20 Nov. 1813 Presid. van Boedelmeesteren.

Braam (Jacob Andries van), geb. in 1771 te Hoegli uit den ViceAdmiraal (gewezen Comps. schipper) Jacob Pieter van B., den veroveraar van Riouw in 1784, en Ursula Martha Feith; een broer van dezen vader, A. E. van Braam Houckgeest, heeft de Comp. lang in China gediend.

Hij werd in 1788 in Nederl. benoemd tot Boekhouder in den Chin. handel; kwam in 1789 op Java en bracht het onder Daendels, die volgens een babad in Bijdr. 1905 p. 237 het met zijne vrouw ${ }^{1}$ ) hield, tot Resident (of Minister) aan het hof te Solo en zelfs tot President der. Hooge Ind. Regeering en Gouverneur-Generaal ad interim in geval Daendels mocht overlijden. Bracht de tweede betrekking hem per jaar $25.000 \mathrm{Rds}$. op, de eerste rendeerde, volgens eigen opgave, 2 à 3 ton. Hij was dan ook zeer rijk en volgens Goldbach (bij Dr. de Roo II, 531) met Daendels de eenige "die schatten onder het verachtelijkst bestier vergaderde"; vergelijk denzelfde bij De Jonge XIII p. LXXXI noot. Van Polanen noemde hem een lafaard, een kruiper, een sjacheraar, een smokkelaar (Dr. de Roo II, 734). De

1) In 1800 trouwde Van B. met Ambrosina Wilhelmina van Rijck, dochter van Adriaan van R., die sedert 1772 Commandant te Pasoeroean is geweest, en Susanna Ernstein. Zij was te Samarang opgevoed ten huize der weduwe van den Raad Extraord. van Indië Anthonij Barkeij. Uit dit huwelijk werd 6 April 1801 geboren Ursula Susanna, die als weduwe van C. P. Jutting den 24 Juli 1833 te Bat. trouwde met J. C. Baud. Van Braam's zwager Gerardus Carolus van $R$. trouwde in 1808 met Ignatia Corn. M. van Riemsdijk en hertrouwde als weduwnaar in 1817 met Elis. Lucia Smissaert van Amsterdam.

Eene Geertruida Helena van $\mathrm{Br}$. is in 1821 te Bat. de vrouw van Hendrik Stephanus van Son. 
dageri tusschen Daendels' aftreding en vertrek bracht deze door in Van B.'s woning (ibid. II, 515). In Juli en Aug: 1811 was H. Tielenius Kruijthoff, oud Secretaris der H. Regeer., met eene geheime opdracht van Janssens in het Solosche werkzaam aan een onderzoek naar de klachten over knevelarij, die tegen Van B. en den secretaris Servatius waren ingekomen; deze begrootte het totaal der baten van den Resident op 182.302 Rds. zilver per jaar plus 146.500 Rds. papier. Na de komst van Janssens was Van B. afgetreden als President der H. Regeer. en weer Resident te Solo geworden, alwaar hij na de verovering de Britsche belangen goed behartigde, hetgeen hem de erkennning van zekere geldelijke pretenties bezorgde. Den 11 Nov. 1811 gaf hij de residentie over aan Adams. De Soenan klaagde zeer over zijne gepleegde schraperijen, maar voorloopig bleef Van B. te Samarang om van advies te dienen. Ook hierbij maakte hij zich zoo verdienstelijk, dat, toen hij naar Bengalen zou gaan om de belangen der Nederl. crediteuren van het Gouv. te bepleiten, Raffles hem bij brief van 29 Jan. 1812 aldaar zeer warm aanbeval. Dat hij weinig scrupules kende, bewees intusschen een schrijven van den Raad van Justitie te Samarang, volgens hetwelk hij zijne schulden zou hebben betaald met à pari berekend Probolinggopapier (Proc. 14 Febr. 1812). Bij Minto wist hij zich zekere geldelijke voordeelen te verzekeren en vrije passage naar Engeland, waarheen hij in Juni 1812 vertrok om de belangen der Nederl. houders van Bataviaasch credietpapier te behartigen bij het Opperbestuur; hierin slaagde hij. In Dec. 1813 was hij te Calcutta terug en den 25 Febr. 1814 te Bat,, waar hij den 24 Maart een bal gaf in zijn superb mansion op Rijswijk ${ }^{\mathbf{1}}$ ). In Londen had Van. B. ook de agentuur bemachtigd van het huis Boehm en Taylor, dat met de Javasche prijsagenten een contract had voor den koop der buitgemaakte koffie. Nu kwam 17 Mei te Anjer het schip Java, Captain Templer, met het officieel schrijven van het Engelsche Ministerie, dat de vijandelijkheden tegen Nederl. waren gestaakt. Den $23 \mathrm{Mei}$ landde Templer in het geheim te Bat,, nog voordat zijn schip op de reede lag, en verborg zich ten huize van Van Braam, die

1) Dit huis is het tegenwoordige paleis van den Gouverneur-Generaal. In 1812 werden voor 30.000 Rds. papier (acte Burger 15 Juni 1812 no. 427) de stallen en koetshuizen daarbij gebouwd; de eigenaar leverde de materialen. Later werd dit huis gehuurd voor den Gouv.-Gen. Van der Capellen en na Van Braam's dood in 1821 door het Gouv. aangekocht ver beneden de waarde. Volgens Gaz. 20 Mei 1815 was er een ledig erf tusschen 'Van B.'s huis en dat van Raffles (het latere Hotel der Nederlanden). 
onmiddellijk voor zichzelf alle koffie in de Gouv. pakhuizen ging opkoopen, waarna Templer zich den 26en met zijne berichten bij Raffles te Buitenz. vervoegde. Hevig verontwaardigd, bracht deze de zaak voor het gerecht, dat beslag legde op de koffie, maar dit later moest opheffen; ook Raffles' order aan Van B. om zich in Bengalen te gaan verantwoorden, bleef zonder gevolg; uit eene acte Drost 30 Mei 1814 no. 4849 blijkt, dat Raffles zelf belast was met de verzending der prijskoffie aan Boehm en Taylor en daarom Van B. niet als zoodanig wilde erkennen. Daar ook Raffles' maatregelen tegen Templer in Bengalen niet werden goedgekeurd, liep dit zaakje voor hem op eene blamage uit. Het volgend jaar had Van B. eene handelszaak te Bat.; begin October vertrok hij naar Europa, volgens Nic. Engelhard omdat hij vernomen had, dat zijn vriend Daendels in Nederland gunstig was ontvangen. Bij de teruggave van Java was daarom Van B. nog absent; nadat hij in Maart 1817 was geretourneerd, werd hij lid der Adviseerende Commissie, vertrok daarna als Commissaris voor de overname der Ned. bezittingen in VoorIndië, en overleed te Bat. als Raad van Indië den 12 Mei 1820. De weduwe hertrouwde 1 Aug. 1821 met Joseph Drury, Captain Royal Navy, die op Java bleef tot zijn dood in 1835 ; de vendutie der weduwe staat pas in Javabode 19 Oct. 1864.

Brandel (A.) van Dresden. Uit een brief naar patria dd. 20 Dec. 1799 blijkt, dat deze persoon als Extraordinair Luitenant der genie was ontslagen, omdat hij beneden zijn stand was gehuwd, ongeacht een verbod van zijn chef. Hij hertrouwt als weduwnaar van Anna Brouwer, begin Juni 1808, zijnde Koopman en eerste landmeter, met Johanna Constantia Neun, eene onechte dochter van den Raad van Indië C. M. Neun; haar zwager was J. F. Arnold, landheer in de Ommelanden. Bij een besluit van Daendels 19 Jan. 1809 werd B. geschorst als landmeter. Bij Proc. 28 Nov. 1811 wordt hij op 150 \$ aangesteld tot ,tekenaar onder de directie van den Luit. Gouv. te Buitenz.”; 20 Juni 1812 wordt vermeld, dat hij naar Tjiandjoer (denkelijk toegevoegd aan Dubois) is vertrokken; Juli 1812 is hij weer te Buitenz. Kort daarna overleed hij. Hij behoorde tot het personeel van Jongkind, den architect. De weduwe hertrouwde 1 Sept. 1822 met Jan Jacob Steitz, den halfbroer van Andries de Wilde.

Brandenburgh (R.), op Java gekomen 1802, was bij de verovering Opziener 2e klas te Bandoeng; wordt 2 April 1812 als zoodanig be-

D1. 92. 
vestigd op $75 \$$. Klaagt 28 Oct. 1812, dat zijn baantje is ingetrokken: hij is verscheiden jaren Opziener te Bandoeng geweest en thans an old man. Komt Proc. 28 Mei 1813 voor als Schout te Oedjoengkrawang. In April 1814 wordt echter een ander benoemd. Hij woont in 1816 op het land Japan.

Broeck (H. A. van den). Bij Proc. 1 April 1812 wordt goedgekeurd zijne voorloopige benoeming (door den Deputy Civil Commissioner) tot Baljuw te Soerabaja op 200 \$. Wordt Fiscaal aldaar, Proc. 21 Oct. 1814. Onder het Ned. bestuur Resid. van Krawang. Overlijdt insolvent 1825 .

Brown (Thomas Campbell) wordt 3 Dec. 1811 (Gaz. 29 Febr. 1812) van Bengalen overgeplaatst naar Java als Assistant Surgeon. Hij wordt ook wel aangeduid en teekent zich M. D., d.i. doctor in de medicijnen. Gaz. 28 Nov. 1812 wordt hij aangewezen to perform the civil duties at the station of Buitenzorg vice Sir T. Sevestre. Te Buitenzorg zal hij kennis hebben gemaakt met Raffles' zuster Leonora, die in Maart 1812 haar man B. Loftie had verloren (zie aldaar) en met welke hij 20 April 1813 trouwde. Raffles zelf verrichtte die plechtigheid! Proc. 16 Juni 1813 wordt hij in plaats van Assey benoemd tot Superintendent of the press (Dupuy werd later zijn opvolger) en Proc. 1 Nov. 1813 tot Timber Storekeeper ter vervanging van Flint, die naar Europa is, op 600 \$; hij was destijds reeds te Samarang en wordt bij General Orders van 12 Dec. 1813 aldaar bovendien tot Garrison Surgeon benoemd. Hare noemt den opvolger van Flint ergens: my friend Dr. Brown; uit een anderen brief schijnt te blijken dat hij zwaar dronk. In Maart 1814 was hij nog Acting Timberstorekeeper te Samarang; den 30 Juni 1814 werd deze betrekking opgeheven. 18 Nov. 1814 meldt hij aan de Regeer. de ontvangst zijner benoeming tot Superintendent General of the Forests, welke betrekking hij nog in Juni 1815 bekleedde, op een salaris van 1.200 Java Roep.; Bauer klaagt in die maand, dat hij nog heel geen rapporten heeft ingediend. Toen zwager Flint eind Juli uit Engeland terugkwam, werd deze echter weer Superintendent. Tegelijk was Brown echter (reeds in Mei 1815) te Samarang Superintendent der Vaccine voor de Center Division op 300 Java Roep.; hij bleef dit tot het herstel van het Nederl. gezag.

Van dezen persoon moet worden onderscheiden een John Brown, die in Oct. 1811 werd benoemd tot Havenmeester te Soerabaja, 
ofschoon hij volgens een schrijven van Gibbs noch Hollandsch noch Maleisch verstond, en wiens salaris in Oct. 1812 beliep 400 \$. Met bijverdiensten werd dit wel 1.300 Java Roep. per maand. In 1816 bekleedde hij nog die betrekking.

Browne (Thomas), in 1815 oud 21 jaar, geb. te Walworth, werd bij Proc. 13 Maart 1815 te Japara geplaatst als Assistant to the Resident op 400 Java Roep.; hij zou eerst Heyland helpen bij den aanslag der landrente en daarna Resident Doornik in het voeren zijner correspondentie in het Engelsch. We vinden hem nog 30 Mei 1816 te Japara, waar hij nog in 1823 een huis en pakhuis bezit.

Volgens Boulger p. 253 trouwde Raffles' zuster Harriet (geb. 1783, uitgekomen 1810) in Oct. 1816 met een Mr. Browne, a gentleman holding a post in one of the offices at Somerset House. Dit zal wel geen der bovenstaanden zijn. Waarschijnlijk is Harriet de Miss Raffles, die een paar maal in de Gaz. wordt vermeld onder de aangekomen of vertrokken passagiers.

Brückner (G.), zendeling en Predikant (volgens Van Troostenburg de Bruijn geboren in Silezië), onlangs op Java aangekomen, wordt bij schrijven van 18 Juli 1814 te Samar. geplaatst als opvolger van den ouden Montanus. Reeds in Febr. 1815 zette B. hier den boel op stelten door eene aanschrijving aan den R. K. kerkeraad. Tot dusverre had namelijk de R. K. gemeente, op grond eener vergunning van Daendels, het Prot. kerkgebouw gebruikt na afloop van den Prot. Zondagsdienst en de voormalige gouverneursbank daarbij als altaar gebezigd; de gemeente was immers te klein en te arm om een eigen kerkje te zetten en onder Montanus had deze verdraagzaamheid nooit tot wrijvingen geleid; Brückner zette de Roomschen echter de deur uit onder pretext, dat men de bank wel eens noodig had als Raffles ter plaatse was. Daarna wilde B. het gebruik afschaffen om aan huis te doopen. Liet men een kind in de kerk doopen, dan betaalde men 1 ducaton; werd dit, om de ijdelheid der ouders te streelen, aan huis verricht, dan kostte het 5 \$. Maar B. vond, dat zijne zondagspreek zeer in de belangstelling der gemeente zou rijzen, wanneer er eene doopplechtigheid mee werd verbonden; bovendien, zei de vlijtige herder, ik zou op laatst niets anders te doen hebben dan rond te rijden om kindertjes te doopen (treffend getuigenis voor de vruchtbaarheid der Samarangsche huwelijken); alzoo, een tweede conflict. Meer tot eere van B. strekt een schrijven 
van hem aan Raffles dd. 19 Febr. 1816, waarin hij verklaart den doop niet te kunnen toedienen aan personen, die niet in staat zijn rekenschap van hunne godsdienstige overtuiging te geven, en dat hij niet als gemeenteleden kan erkennen of tot het Avondmaal toelaten wie van een onchristelijk leven is. Hij vroeg dus ontslag en kreeg dit bij schrijven van 8 April 1816. Volgens Van Troostenburg de Bruijn ging hij datzelfde jaar ,over tot het Engelsch BaptistenGenootschap", en werkte hij voortaan als zendeling onder de Javanen. In 1825 vinden we hem te Samar. bezig an eene Jav. vertaling van het $\mathrm{N}$. Testament, die 1829 gedrukt is; later verschenen eene spraakkunst, gedrukt te Serampore in Bengalen 1830, en een woordenboekje van het Jav. van zijne hand. In 1828 verliet hij het eiland.

Bruijn $(J . d e)$ bij de verovering Landdrost van Bantam. Werd dit opnieuw na de teruggave.

Zijn broer Pieter de Bruijn kwam in 1817 uit als soldaat, maar was al spoedig daarna Controleur in het Bantamsche (Van Rees, Toontje Poland I, 212; 227).

Een De Bruin wordt 6 Sept. 1813 prov. benoemd ,to resume the office of Member of the Court of Justice” (blijkbaar te Bat.).

Burger (Mr.J.) kwam volgens eigen getuigenis op Java in April 1810. Wellicht was hij naar Holland gegaan om er den meesterstitel te verwerven, want reeds veel vroeger was hij te Bat. werkzaam geweest, zie Bijdr. 73, pag. 231. Einde 1810 is hij Advocaat te Bat.; wordt 2 Nov. 1811 benoemd tot Notaris ,dezer stede” in plaats van Boswel. Voor het geval dat hij als Notaris zal aftreden, wordt bij Proc. 13 Maart 1815 Van de Poel tot opvolger aangewezen.

Burghgraaf (Jan Willem), geboren te Bourtange, op Java gekomen 20 Febr. 1793, zoon der zuster van Cranssen en gewezen Opperhoofd van Saparoea, wordt 21 Jan. 1812 Baljuw der stad Bat.; wordt Gaz. 14 Mei 1814 Fiscal Supreme Court op 660 Java Roep.; wordt Gaz. 21 Oct. 1815 Additional Member van dat Court op 500 Java R. Was gehuwd met Josina Johanna de Grave. Wordt Vendumeester te Bat. in 1819 en overlijdt als zoodanig 11 Dec. 1822. Zijne weduwe sterft in 1835 te Bat.

Burncy $(R$.) was blijkens archiefpapieren de kleinzoon van Dr. Ch. Burney, den muziekkenner, vriend van Samuel Johnson en vader 
van de Madame D'Arblay, aan welke Macaulay eene studie wijdde; deze grootvader beval hem aan bij Lady Moira. Was blijkens de stukken van zijne hand een onbeduidend mannetje. Wordt, zijnde Ensign der native infantry, bij General Orders Calcutta 19 Mei 1812 aangewezen voor dienst op Java. 24 Juni 1814 schrijft de Regeer., dat Raban als Resident van Cherib. wordt vervangen door Lieutenant B.; den 27 Juni neemt deze de residentie over en geeft haar 27 Aug. 1814 over aan Davy, dien hij conform Gaz. 30 Juli 1814 zou vervangen als Assistant Resident te Soerabaja. Burney nam 7 Sept. 1814 de residentie Soerabaja over van Pemberton en gaf haar 1 Oct. 1814 over aan Crawfurd, wiens Assistant hij bleef op 800 Java Roep., tot Raffles hem 28 Juni 1815, te Soerabaja zijnde, twee maanden verlof wegens ziekte verleende. Proc. 10 Aug. 1815 wordt hij benoemd tot Collector of Revenue te Samarang, waarheen hij 5 Sept. van Bat. vertrekt; hij trad als zoodanig (als opvolger van Cotes) den 12 Sept. op. Bij schrijven van 1 Dec. 1815 werd hem gelast, zich weder bij zijn regiment te voegen en zijn werk over te geven aan den Resident van Sam., hetgeen echter eerst 31 Jan. 1816 (aan Bidwell) plaats vond.

Burslem (N.) nam deel aan de expeditie tegen Java en werd 29 Sept. 1811, zijnde Major van H. M. 14th regiment, benoemd tot Deputy Barrack Master General; bij General Orders 19 Maart 1812 belast met het commando der Batavian Division, dat hij reeds 22 April 1812 overgeeft aan Eales. Bij General Orders 2 April 1814 opnieuw als Lieut. Col. belast met het commando der Western Division. Bij Gen. Orders 3 Aug. 1815 belast met het commando der Eastern Division, terwijl de betrekking van Deputy Barrack Master General wordt afgeschaft. Toen 27 Oct. 1815 de brief van het Supreme Government was behandeld waarbij, ter vervanging van Nightingall, de next senior officer at Java werd belast met het legercommando, moet hij naar Bat. zijn opgeroepen, doch eerst onderdrukte hij nog de Sepoy samenzwering (Van Deventer pag. 58). Proc. 6 Dec. 1815 wordt vermeld, dat hij is aangewezen to a provisional seat in Council; hij neemt dien dag zitting als Acting Member of Council untill the pleasure of the Supreme Govt. shall be known, en toen Raffles een paar weken later op reis ging, benoemde deze den 1 Jan. 1816 Burslem tot waarnemend Vice-President, als hoedanig hij den volgenden dag zitting nam. Hij sloeg nooit eene vergadering over. Den 14 Mei 1816 woonde hij de vergadering het laatst 
bij, den dag daarna verving Grant Keir hem. Den 26 Mei vertrok hij met zijne vrouw naar Samarang, na opnieuw met het bevel over de Eastern Division te zijn belast (Gaz. 1 Juni 1816). Den 15 Sept. 1816 komt hij van Samar. te Bat. Zijne vrouw was Sarah Norris Brooke. Of dit eene verwante kan zijn van James Brooke (geboren te Benares 1803) en deze laatste aldus misschien reeds als kind van onze Oost kan hebben vernomen, is mij niet bekend. Uit dit echtpaar werd 11 Juni 1813 een kind gedoopt met den naam Rollo Gillespie, maar 2 Sept. 1814 een tweede kind met de namen Olivia Flora (naar Mevr. Raffles en Lady Nightingall).

Busscher (J. T.); bizonderheden omtrent hem in Priangan IV p. 710. Geboren in O. Friesland; komt in Indië 1789 of 1790 als jongmatroos; wordt leerling der Samarangsche Marineschool, in 1795 Achtste informator bij die inrichting op 5 Rds. per maand; 1799 Sous-lieutenant ter zee; was bij de verovering Kapitein der artillerie en Tweede informator dier school, daarna Eerste informator en chef dier inrichting; werd 27 Oct. 1812 op verzoek ontslagen. In 1813 vinden we hem als schoolmeester te Sam.; in 1814 vraagt hij tevergeefs om landmeter aldaar te worden. Hij had altijd veel aan opnemen gedaan (was reeds in 1802 met twee leerlingen der Marineschool naar Cheribon gezonden om ,het rif” in kaart te brengen), en 23 Juni 1812 schrijft Cornelius dan ook, dat hij dit jaar B. met een landmeter 2e klas en een élève wil gebruiken voor de opneming van Kedoe en van de zuidkust; Proc. 15 Aug. 1812 wordt hem de opneming opgedragen der kust van de Wijnkoopsbaai tot Anjer. Hij placht ook de berekening te maken voor den Bataviaschen almanak. Ds. S. Roorda van Eysinga vertelt, dat op zijne reis naar Makassar anno 1821 de ,kaart van Busscher” zeer slecht bleek te zijn (Verschill. reizen I, 2, p. 17). Den 25 Jan. 1817 wordt hij benoemd tot kapitein bij het corps Pionniers en geplaatst „bij het kadettenschool alhier" d.i. te Bat. evenals de voormalige kadet J. G. Steinmetz, die benoemd wordt tot 2e Luit. Maar reeds 26 Juli 1817 worden beiden op verzoek ontslagen. Zijne vrouw was J. W. Ham.

Cassa (Anthonij Abraham), geb. te 's-Gravenhage 1759, op Java gekomen 1794 als gewezen officier, trouwde Anna Maria, de dochter van B. F. von Liebeherr, Resident te Solo (en was daardoor de zwager van A. H. Smissaert); was bij de verovering buiten betrek- 
king, eigenaar van het land Soedimara; man van zeer geringe ontwikkeling. Wordt bij publicatie van $21 \mathrm{Jan} .1812$ tweede lid van het Supreme Court of Justice op 250 \$. Had zijne zaken zoo goed beheerd, dat hij in Febr. 1813 aan de Weeskamer 130.000 Rds. schuldig was en Soedimara en zijn huis op Noordwijk te koop bood (Gaz. 22 Mei 1813). Gaat dat jaar met de eerste expeditie naar Japan ,als bestemd tot Opperhoofd" (Doeff p. 190), vanwaar hij 20 Dec. 1813 terugkomt met o.a. den heer T. Cassa. Gaat begin Juli 1814 met de tweede expeditie naar Japan, na, blijkens Proceed. 8 Juni 1814, benoemd te zijn tot Factor for the Japan trade in the present year en wel op $500 \mathrm{Sp}$. Ds. per maand en komt vandaar 12 Dec. 1814 (met zijn zoon) terug. Naar aanleiding dier reizen makte hij aanspraak op zekere voordeelen, die Doeff beweerde dat aan hem zelven toekwamen. Wordt Proc. 17 Febr. 1815 benoemd tot lid der Bench of Magistrates; Proc. 22 Maart 1815 tot waarnemend Baljuw van Bat.; hij treedt af als Magistrate; als Baljuw bevestigd Proc. 22 Aug. 1815 ; wordt ook weer Magistrate Proc. 28 Sept. 1815. Was in 1817 nog Baljuw en overlijdt 23 Sept. van dat jaar. Zie ook Van de Graaff II, 37.

Christiani (Diederik), geb. in Holstein, kwam eerst 28 Sept. 1811 op Java; is Proc. 10 Oct. 1812 Second Assistant in the Accountant's office op 250 \$ en Dutch translator in the Lt. Gov.'s office op 250 \$; bij publicatie van 28 Mei 1813 benoemd tot lid der Weeskamer op 150 \$; wordt Proc. 13 Aug. 1813 bovendien translator to the Revenue Committee (voor het in 't Eng. vertalen der pachtvoorwaarden); is in April 1814 a member of the Committee appointed to investigate and report on the relations formerly subsisting between the Dutch E. I. Company and the different states in the Eastern Archipelago; is Proc. 30 Juni 1814 hoofd van het Dutch translator's office op niet minder dan 1.000 Java Roep.; wordt Proc. 22 Dec. 1814 waarnemend Secretaris der Weeskamer, en Proc. 6 Jan. 1815 nogmaals lid en Secretaris van dat College met een commissiegeld van $3 \%$ op alle verkoopingen; wordt Vice-President der Weeskamer Proceed. 27 Oct. 1815 op 750 Java Roep. p. m. In Aug. 1816 had de Weeskamer eene geldelijke pretentie op hem als gewezen Secretaris. Wat de verklaring der buitengewone begunstiging van dezen persoon is, valt moeielijk te raden; wellicht hielp hij Raffles bij zijne archiefnasporingen. Overlijdt insolvent 24 April 1818. 
Clark (J.). Den 9 Dec. 1811 benoemt Raffles, te Soerabaja zijnde, Captain James C. to the temporary command of Samanap and to execute the civil duties on the island of Madura, op \$250 (hij schijnt deze functies, of een deel daarvan, al eerder te hebben waargenomen). De Gaz. 4 April 1812 bevat zijne benoeming to command at Banyowangie and to perform the civil duties at that station in the room of captain Knight; maar reeds 31 Maart 1812 fungeerde hij als zoodanig. Bij Proc. 23 Dec. 1812 wordt een opvolger voor hem aangewezen als Resident te Banjoewangi (het salaris was maar 80 \$), maar reeds Proc. 4 Nov. 1812 werd C. benoemd tot Commandant van Madoera en civiel gezaghebber van Soemenap, ja reeds Proc. 10 Oct. 1812 treffen wij hem als zoodanig aan, ofschoon hij eerst 2 Jan. 1813 de residentie Banjoewangi aan den officier Joseph Mackenzie overdroeg. Den 13 Jan. 1813 nam hij de afdeeling Soemenap over van den waarnemenden Resident Dragheim en gaf haar 23 April 1816 over aan D. Macleod. Clark maakt den indruk van een bekwaam en eerlijk man, te eenvoudig om de finesses van Raffles te vatten. Toen hij bij een schrijven van 20 Febr. 1816 had verzocht om bij den troep te Soerabaja te worden geplaatst en tevens Resident van Soemenap te blijven (wat met het oog bijv. op Davy, die als Resident van Bangkalan steeds te Soerabaja was blijven wonen, niet ongehoord zou zijn geweest), kreeg hij Proc. 11 Maart 1816 in laatstgenoemde betrekking zijn ontslag. Bij de teruggave was hij Commandant te Soerabaja.

Cluver (Ds. F. C. H. A.) kwam in April 1810 uit Europa, treedt op als Predikant te Bat., doch vertrekt reeds in Oct. 1811 naar zijne nieuwe standplaats Malakka. De Minister prees 1809 (Dr. de Roo I, 218) ,zijne bereidvaardigheid, tevredenheid om alle schikkingen zich te laten welgevallen en zagt voorkomen"; hij was echter een Duitscher en sprak slecht Hollandsch.

Colebrooke $(W$.$) , Lieutenant Royal Artillery, daarna Captain,$ vervolgens Major; wordt gewond bij de bestorming van Meester Cornelis; onderscheidt zich bij de verovering van den kraton van Djokja (Conquest p. 50; 194); wordt 2 Juli 1812 door Raffles aangewezen to survey the Solo river, op een toelage van 858 Sonat Rupees p.m., waaruit hij echter alle onkosten moet voldoen; bij Gen. Orders 11 Oct. 1812 benoemd tot waarnemend Military Secretary to the Commander of the Forces; Gaz. 3 Juli 1813 benoemd 
tot Deputy Quartermaster General; als zoodanig vervangen 1 Aug. 1813; was van 13 Aug. tot 18 Sept. 1813 Political Agent of Govt. at Palembang om het door Robison gesloten contract ongedaan te maken; sloot aldaar een nieuw contract (Bijdr. 1900 p. 692). Wordt 6 Oct. 1813 weder waarnemend Military Secretary to the Commander of the Forces, doch vertrekt reeds 17 Nov. 1813 naar aanleiding der Palembangsche zaken met Methven naar Bengalen, vanwaar hij pas 24 Jan. 1815 terugkeert; wordt Gaz. 28 Jan. 1815 weder Deputy Quartermaster General; wordt Gaz. 25 Maart 1815 Deputy Adjutant General; dit wordt ingetrokken bij General Orders 27 Oct. 1815; wordt weder Military Secretary to the Commander of the Forces, Gaz. 18 Mei 1816. Een naamgenoot van hem, de beroemde Oriëntalist H. T. Colebrooke, was tijdens Minto Member of Council te Calcutta.

Conroy (L.), Lieutenant, wordt Proc. 10 Aug. 1815 ter vervanging van Hanson benoemd tot Superintendent der Gov. Gazette. Krijgt bij Gen. Orders 24 Juli 1816 verlof naar Europa; vertrekt 6 Aug.

Cornelius (Hermanus Christiaan), wordt reeds onder het Nederl. bestuur ook wel Cornelis genoemd, door de Engelschen meestal $\mathrm{Mr}$. Cornelis, Major Cornelis (ook in officieele stukken), terwijl omgekeerd de plaats Meester Cornelis soms Mr. Cornelius heet, zoodat men sprak van the conquest of $\mathrm{Mr}$. Cornelius. Geboren te Amsterdam in 1769; kwam in Indië 1791 als cadet op de Christophorus Columbus; werd leerling op de Samarangsche Marineschool, en in 1794 Zevende informator bij die inrichting; werd 1798 Vaandrig ingenieur te Samarang; 1803 Luitenant; 1807 Kapitein; 1808 te Soerabaja; 1809 Majoor en Ridder te Soerabaja; 1810 aan de Merakbaai. Uit eene aanteekening van N. Engelhard blijkt, dat C. reeds als Vaandrig aan het in kaart brengen van Java meewerkte. Wanneer Horsfield zegt (Verh. B. G. VIII, 44), dat C. in 1790 zekeren berg in Pekalongan beklom, zal wel 1799 bedoeld zijn. Datzelfde jaar nam hij ook de baai van Patjitan op (De Jonge XII, 561).

Reeds in 1794 werden aan den Franschen natuurkundige Louis Deschamps, die van de expeditie onder D' Entrecasteaux op Java was gebleven, ,eenige jongelingen tot het teekenen van al wat hem in zijne onderzoekingen zeldzaam voorkomt, toẹgevoegd" (Verslag der Marineschool dd. 4 Maart 1797). Gelijktijdig werden steeds, behalve het voortdurend copieeren van aanwezige kaarten, ook op- 
nemingen begonnen. Het verslag der Marineschool dd. 2 Febr. 1803 zegt, dat door den Gouv. van Java's N. O.-Kust J. F. Baron van Reede tot de Parkeler ,verscheide jongelingen (der Marineschool) zo tot het maken van aftekeningen als het opnemen van landen en negorijen, zijn geëmployeerd geworden", d.i. in 1801. Misschien begon dus reeds onder Van Reede ook de opneming der oudheden. Deze gaf echter al 16 Sept. 1801 het bestuur over aan N. Engelhard. Zoo werd in 1794 tot 1798 (en ook de eerstvolgende jaren tot 1802) Cornelius gebruikt voor ,de verdere afmeeting der districten van Samarang en de daaronder gehorende Regentschappen alsmeede een gedeelte der landen van de Vorsten" (Verslag Marineschool dd. 27 Dec. 1799). Terwijl hij aldus kaarten teekende, werden op last van $\mathrm{N}$. Engelhard ook reeds in 1805 teekeningen vervaardigd. Immers een rapport van dat jaar aangaande de Marineschool zegt: „,Den 21 Maart is den Captn. ter Zee en Eerste Informator H. W. van Waeij, den Luijtenant en derde Informator H. P. D. Kortzius en den Cadetonderwijzer H. Muijderman naar Toegoe geweest tot het afteekenen van den aldaar leggende steenen". Zie ook onder Wardenaar (J.W.B.).

In 1807 vervaardigde Cornelius eene beschrijving van Tjandi Sewoe (Verh. B. G. VII no. IX p. 9). Hij was de man, die voor Daendels het fort Lodewijk bouwde, waarvoor hij werd geridderd, zegt Van Waeij, die hem gekend heeft. In Oct. 1811 bericht hij aan de Regeer., dat hij volgens bekomen last zijne decoratie heeft afgelegd. In welke qualiteit hij in Eng. dienst overging, blijkt niet. Proc. 4 Jan. 1812 komt hij voor als Civil Surveyor and Superintendent of Buildings te Sam. op 200 \$ met 6 vrij dure teekenaars onder zich. Den 13 Febr. 1812 wordt hij belast met het bouwen van kazernes te Salatiga; op 's Konings verjaardag leverde hij (Gaz. 13 Juni 1812) de illuminatie te Samarang, waarbij Raffles tegenwoordig was.

Den 18 Febr. 1812 schrijft hij aan Raffles: I together with the lately employed (versta: de gewezen) officers (whom I have been fortunate enough to engage agreeable to your Excellency's desire) am now busy with forming the collection of drawings from the Bramin antiquities who are found on Java, to which a complete inscription (sic) relative to the construction and situation of these buildings will be added, in order that this work may obtain the honor of being presented to your Excellency. In the execution of my work, so well by the drawing as other works, I am assisted by eight mathematical drawers or draughtsmen whereof four are of the first 
and four of the second class, of which two are permanently employed by the works of architecture; the rest keep themselves busy with the abovesaid Bramin drawings and in arranging some charts requested by Colonel Mackenzie"; maar als de droge tijd begint, zal hij de bekwaamsten uitzenden tot het doen van opnemingen voor het in kaart brengen van Java.

Den 10 Maart 1812 schrijft hij aan Raffles over kaarten en voegt daarbij: For the want of good draftsmen since the departure of the last I sent you (namelijk Flikkenschild en Karsseboom) I have not been able yet to complete the drawings of Bramin antiquities in hand for your Excellency. Blijkens eene rekening waren in Sept. 1812 een teekenaar eerste klas en een tweede klas te Prambanan werkzaam.

$\mathrm{Hij}$ werd dat najaar belast met de vestiging der kolonie op Karimon Djawa; hij schrijft, dat hij aldaar een zoon van hem wil plaatsen who was formerly an officer of the engineers; dit zal de H. C. Cornelius zijn, die 27 Juli 1813 te Sam. overleed en zijn oudste zoon was. Zijn eenige dochter trouwde te Samar. 8 Juli 1815 met B. G. Sartorius. Buiten deze twee kinderen moeten er nog twee zoons zijn geweest; een daarvan, Pieter, overleed op Banka 21 Aug. 1823. Cornelius' dienst schijnt nogal onaangenaamheden te hebben meegebracht. OP Karimon Djawa, dat hij in kaart bracht, werd hij zwaar ziek. Den 3 April 1813 brengt Resident Garnham zijn verzoek over om ontslag als Civil Surveyor, waarop de Regeer. antwoordt, dat zij een afzonderlijken Superintendent of Buildings niet noodig heeft en hij dus beide betrekkingen samen moet blijven vervullen.

Den 3 Juni 1813 zendt hij een rapport van verrichte werkzaamheden, waarin betreffende de archeologische opname alleen voorkomen seven drawings of Bramin temples which have been forwarded to his Exc. the Honble the Lt. Gov.; also few other drawings of the Bramin antiquities and discriptions, which have not yet been finished for want of time. Den 26 Dec. 1813 belast de Regeer. hem bovendien met het werk van den Gezworen Taxateur (die afgeschaft wordt) en wel tegen een vierde der vergoeding, welke deze laatste genoot. Den 24 Jan. 1814 besnoeit Raffles zijn personeel en zijne bevoegdheden en gelast hem zich in Kedoe ter beschikking te stellen van Resident Lawrence. Proc. 8 Maart 1814 werd in zijne plaats Lieutenant Wetherall benoemd tot Superintendent of Public Buildings (dus nu was dit weer wèl geschikt voor eene afzonderlijke betrekking) en in eene minute, geïnsereerd in Proc. 30 Juni 1814, spreekt Raffles van ,the removal of the Civil Surveyor's office from 
Samarang, where its continuance is not only no longer necessary but irregular", en wel op eene wijze, alsof dit kantoor reeds verplaatst is. We zien echter met 1 Aug. 1814 de werkzaamheid beginnen van eenen „Land surveyor general” wiens naam nergens blijkt. Wellicht is dit Cornelius. Het salaris was $\mathbf{5 0 0}$ Java Roep.; onder hem stonden 12 surveyors op 200, 6 op 150. Cornelius bleef echter een salaris van 440 Java Roep. trekken tot ulto. Sept. en vertrok 5 Oct. 1814 naar Buitenzorg, terwijl zijne betrekking werd opgeheven; des te meer zal hem dit vertrek hebben gespeten, omdat hij juist bezig was ,in mijn thuijn buijten de oostpoort" een nieuw huis te bouwen. Hij moest (volgens eene aanschrijving van 13 Oct., die de herhaling van vroegere orders was) met zich brengen all the charts, plans and other muniments (d.i. documenten) of his office (zie onder K. Mackcniie). Uit eene declaratie blijkt, dat hij deze kaarten bracht naar Rijswijk, dus de woning van Raffles. In het archief berust nog eene declaratie van Cornelius dd. 22 Dec. 1814 voor travelling expenses of the undersigned and his assistant; de eerste opname van dat jaar had Prambanan betroffen en duurde van 15 Maart tot 27 April; daarvan was hij 37 dagen bezig met de opname van the small Hindow buildings and a pallace; de tweede duurde 60 dagen in Mei en Juni en betrof Bollo Boedoor (aldus schrijft C. eigenhandig); bij deze laatste opname waren 46 koeli's gedurende 52 dagen bezig to clear the places etc. by surveying the holy hindow buildings. Met zijn werk op den Diëng in Oct. en Nov. zijn dit dus de opnamen van hem in 1814 geweest. Curieus is, dat zijne dagelijksche onkosten voor logies e.d., à anderhalve \$ per dag, door Raffles werden geschrapt. In een rapport over Juli, Aug. en Sept. 1814 spreekt hij nog van het teekenen van Brahmin antiquities door zijne assistenten. In Februari 1815 vinden we hem echter reeds te Sam. terug. Wat zijn werk betreft, hij zelf schrijft 23 Mei 1815: I am at present in the private employ of the Honble the Lieut. Gov. Intusschen werd bij aanschrijving van 15 April 1815 de Superintendent of Public Buildings te Samar. ook afgeschaft en diens werkzaamheden opgedragen aan den Resident. Den 23 Mei 1815 schrijft hij, dat het niet mogelijk is, om vóór Raffles' komst aldaar af te maken all drawings etc. of Bramin antiquities and particularly the large general draught; maar some neat drawings are again in readiness. Het hier bedoelde groote stuk is denkelijk hetzelfde, dat hij in een brief van 25 Nov. 1815, eveneens uit Samarang, noemt the large piece of workmanship on which two drawmen have daily been employed from morning to night, even Sundays not ex- 
cepted. In dezen laatsten brief klaagt hij, dat ingevolge eene aanschrijving dd. 1 Nov, door hem alle voltooide en onvoltooide teekeningen zijn opgezonden ,in consequence of which a stop has been put to the works for your Excellency"; door het voortdurend teekenen heeft zijne gezondheid geleden; zijne brieven blijven onbeantwoord en salaris als taxateur geniet hij niet. Waarop Raffles den 26 Dec. 1815 antwoordt, dat de teekeningen niet uit ontevredenheid waren opgevraagd, maar omdat zij noodig waren and sufficient time had been expended on them; the Lieut. Gov. duly appreciates the merit of the works executed by $\mathrm{Mr}$. Cornelius. Cornelius werkte dus in elk geval tot Nov. 1815 voor Raffles; wij zien voorts, dat in April 1815 aan hem uitbetaling van salaris over de maanden Juli, Aug. en Sept. 1814 geschiedt voor hem en de teekenaars Van der Geugten, Berg en Ligtman, die dus vermoedelijk onder zijne directe orders stonden. Na Raffles' vertrek schrijft Assey 28 Maart 1816, dat Cornelius at present not in regular employ is bij het Gouvern. Hij vertoefde echter van 4 Mei tot 3 Juni 1816 te Bat. en kreeg toen denkelijk eene toezegging van Commiss.-Gen., althans in Aug. 1816 noemt hij zich weer Sworn Surveyor te Sam. Werd bij de oprichting in 1818 (geopend 20 Aug. in de Vrijheid; leerlingen bij de opening o.a. D. F. en P. Cornelius) Luit. Kol. en Directeur der Mil. school te Samarang; verkoopt 1821 zijn tuin Veel Genoegen beoosten Samarang aan zee. Gaat einde 1823 als Kolonel en Directeur der Mil. School naar Nederland. Deze school is 1826 door Du Bus opgeheven (Roorda v. Eysinga, Verschill. reizen III, 83).

Wat omtrent zijn karakter verluidt, is niet bepaald gunstig. Hope verbiedt hem 13 Febr. 1813 on voor particulieren te werken. Resident Garnham schrijft 30 Jan. 1813 dat eigenbelang hem drijft, geen beroepsijver; in een schrijven van 10 Jan. 1813 noemt deze hem very dilatory and too indifferent about the execution of such work as he has in hand; en dat de Regeer. deze meening deelde, schijnt wel te volgen uit haar schrijven van 13 Mei 1813 betreffende haar voornemen om het office conducted by Mr. Cornelius te brengen on a more efficient footing. Of hij een eerlijk man was, weet ik niet; ik zie hem voor een dozijn teekenpotlooden $10 \$$ in rekening brengen, dus meer dan 3 gulden per stuk, maar de prijsbepaling van Europeesche artikelen was destijds zeer onregelmatig.

Raffles vermeldt (History II, 17 noot en 18 noot), dat Cornelius in 1807 eene teekening zoowel van een der kleinere tempels van Prambanan vervaardigde als ook eene van den grooten tempel aldaar; 
beide worden in dat werk gereproduceerd (tegenover bl. 16 en 20). Naar die reproducties te oordeelen, waren dit teekeningen in O.-I. inkt. Wanneer Raffles (ib. p. 30 noot) verder aanteekent, dat in zijn bezit zijn ,drawings of the present and former state" van den Boroboedoer, dan slaat althans dit laatste denkelijk ook op Cornelius. Uit het bovenstaande blijkt echter voldoende, dat het aantal der door C. met zijne assistenten vervaardigde teekeningen belangrijk genoeg moet zijn geweest; Raffles heeft voor zijn werk evenwel slechts een paar daarvan kunnen gebruiken, en daarom is het niet bepaald te verwonderen, dat hij nergens anders van Cornelius melding maakt. Wel zou het billijk zijn geweest, dat hij had vermeld, hoe N. Engelhard als Gouverneur van Java's N.-O. Kust zijn best had gedaan voor het in beeld doen brengen van Hindoe-monumenten. Zie nog Krom in Bijdragen 75, 384 en 76, 435. Cornelius' vrouw heette J. C. Luijken.

Cotes $(W$.$) , Lieut. 3d Batt. Bengal Volunteers, wordt gewond bij$ den aanval op Meester Cornelis (Conquest p. 68). Blijkens Gaz. 8 Aug. 1812 was hij tijdens de expeditie tegen Djokja Commandant te Oengaran. Bij Gaz. 13 Febr. 1813 wordt hij in de plaats van Heyland benoemd tot het commando der Djajangsekars in the Samarang Division, dus over verschillende residenties. Den 13 Juni 1813 schrijft de Regeer. in verband met Crawfurd's onderhandelingen over de terugname der Chineesche landen in den Oosthoek, dat, als hij die heeft voltooid, hij Cotes met de noodige instructies moet laten in charge of the districts. Toen dus Crawfurd den 26 Juni vertrok, bleef Cotes in civil charge of Prob., Besuki and Panarookan; toen Proc. 24 Aug. 1813 Garnham tot Resident daarover werd benoemd, werd tevens bepaald, dat Cotes met de waarneming bleef belast; den 17 Sept. 1813 gaf hij die districten over, echter niet aan Garnham doch aan Hopkins, en vertrok op bekomen last naar Bat.; Proc. 15 Oct. 1813 wordt hij benoemd tot waarnemend Assistant Secretary to Govt. in the Revenue Dept. op 120 \$, doch reeds 2 Nov. 1813 wordt hij op verzoek als zoodanig ontslagen, om als waarnemend Secretaris van Raffles met dezen op reis te gaan. Hij bleef dezen ter zijde, tot hij 24 Jan. 1814 werd benoemd tot Collector of Revenue in de residentie Samarang op 1.200 Java Roep., welke tak van dienst tevens aan den Resident werd onttrokken; Addison werd zijn opvolger. Bij schrijven van 8 Nov. 1814 werd hij waarnemend Resident van Samarang; nam dit 19 Nov. over van Adams en gaf het 16 Jan. 
1815 over aan W. Ainslie, den Assistant Surgeon, (volgens Carey, I, 66, stond deze rang gelijk met dien van cadet en beneden Lieutenant en Ensign), die dan ook van Luitenant C. alras te hooren kreeg, dat hij zich volkomen als gelijke van den Resident beschouwde, en dat hij weigerde op diens last den weg voor zijn huis te besproeien, want dat dit heerendienst zou zijn, en de heerendiensten waren afgeschaft. Dergelijke stukjes vertoonde C. wel meer. Intusschen prees Raffles zijne verdiensten in zake het Rev. Dept. Den 17 Juli 1815 zond het Hoofdkwartier te Weltevreden hem eene order om zich weer bij den troep te voegen, teneinde naar Bengalen terug te keeren; eerst 12 Sept. gaf hij zijn werk over aan Burney, kwam 25 Sept. te Bat.; maar is in Oct. en Nov. van dat jaar weer in O. Java werkzaam als lid der Commissie Lawrence c.s. en neemt 13 Dec. 1815 het werk van Eckford over als Collector of Revenue te Soerabaja. Bij schrijven van 2 Jan. 1816 belastte de Regeer. hem met de landrenteheffing in Grissee, doch reeds $18 \mathrm{Jan}$. benoemt zij hem tot Resident van dat gewest; den 1 Febr. neemt hij de residentie over van Van Naerssen, en werd in diezelfde maand tevens benoemd tot Collector of Customs. Hij trok 1.200 Java Roep. Hij bleef Resident aldaar tot de teruggave. Hij is daarna op Java gebleven; werd koffieplanter in de Vorstenlanden (zie Doornik, Vrijmoedige gedachten p. 268). Hij was een der persconlijke vrienden, die bij Raffles' heengaan een afzonderlijk adres tot hem richtten (Boulger p. 215), en had met dezen den lust voor studie en voor breede, soms wat winderige beschouwingen en groote woorden gemeen. Fabriceerde ook verzen; er staat er een in Gaz. 13 Juni 1812. Den 5 Aug. 1814 doet hij als Collector te Samar. aan Raffles het voorstel om, als de klapperbelasting 14 dagen na den termijn niet betaald is, deze tot straf te verdubbelen en met die verdubbeling verder alle 14 dagen voort te gaan (was men een jaar achterstallig gebleven, dan zou dit per klapperboom 67.108.864 stuiver zijn geworden). Zijne verhouding tot Raffles verklaart, waarom Fendall niets dan scherpe woorden voor C. had.

Den 11 Dec. 1814 trouwde hij met eene dochter van den Samarangschen dokter J. J. Hoff (wiens grafschrift staat bij Campbell I, 477). Hij overlijdt krankzinnig in den ouderdom van 36 jaar den 7 Oct. 1826 te Buitenzorg; weduwe C. W. F. Hoff.

Couperus (Abraham), geb. te Leeuwarden in 1752, werd 7 Mei 1778 geplaatst te Malakka, gaf dit over in 1795 en werd naar Madras 
gezonden (Bijdr. 1908 p. 258, 266); verblijft daarna tot 1807 te Tranquebar. Om Siberg genoegen te doen, maakte Daendels hem Raad Ordin. van Indië; den 1 April 1808 legde hij den eed af. Moet daarna weer naar den vasten wal zijn teruggekeerd, want 17 April 1812 schrijft het Supreme Governm. dat hij nu naar Java zal vertrekken; hij ontving van Minto een voorschot, kwam 6 Juli 1812 te Bat. en maakte zich reeds in September verdienstelijk door het op touw zetten van eene adresbeweging om den Lt. Gov. geluk te wenschen met den terugkeer van zijne groote reis. Bij Proc. 4 Nov. 1812 wordt hij belast met de waarneming van het presidium van den Raad van Justitie te Soerabaja, op 400 \$; wordt daarin bevestigd Gaz. 9 Jan. 1813; overlijdt aldaar insolvent 12 Juli 1813; volgens zijne weduwe Cath. Joh. Koek was hij failliet gegaan door ,eene ongelukkig gedreeven handel op Tranquebaar" (acte Top 20 Aug. 1813 no. 359). De weduwe krijgt eene toelage Proc. 24 Aug. 1813; zij overleed te B.zorg, 80 jaar oud, den 11 Febr. 1843.

Kinderen uit dit echtpaar zijn:

1. Petrus Theodorus, geb. te Malakka 1787, werd in Nederl. opgevoed, kwam op Java 10 Mei 1809, was einde 1810 gezworen klerk bij het kabinet van den G.-G., wordt bij een schrijven van 2 Sept. 1811 provisioneel belast met de betrekking van Landdrost der Bataviasche Regentschappen; stelt reeds 30 Oct. 1811 voor om dit gewest te splitsen, hetgeen alras zijn beslag kreeg, zoodat C. bij besluit van 23 Nov. 1811 Commissary van het district Tjandjoer werd op 300 \$. Na den dood van Hartsinck op 19 Dec. 1811 trad hij ook op als waarnemend Landdrost van Buitenzorg, hetwelk hij 30 Mei 1812 overgaf aan Davidson. Den 4 Nov. 1812 werd hij benoemd tot Deputy Collector te Bat. op 350 \$, later 600 Java Roep., en bij publicatie van 28 Mei 1813 bovendien tot Secretaris van het Commercial Committee op 100 \$, welk salaris den 24 Aug. 1813 werd verhoogd tot 150 \$; later was het 500 Java Roep.; bij Proc. 15 Aug. 1815 wordt hij ook nog collecteur der slavenbelasting, op een commissiegeld van $5 \%$. Gaat later in Nederl. dienst over; was toen eigenaar van Kramat Tjilodong (bij Depok) en Noesa Kembangan; overlijdt insolvent op reis naar Nederland 2 Jan. 1823. Hij had 3 Febr. 1812 te Tjandjoer getrouwd Catharina Rica Cranssen (dochter van W. J. Cranssen en Maria Eleonora Hartman; geb. te Bat. 17 Dec. 1795, overl. te Amsterd. 24 Nov. 1845, na hertrouwd te zijn met C. J. Riesz van 's-Hertogenbosch, die Generaal is geweest); den 4 Juli 1813 werd gedoopt hun zoon William Jacob Thomas Raffles. Een 
andere zoon was John Ricus, die de vader werd van den schrijver Louis Couperus. Merkwaardig is, dat toen de Deputy Collector den 3 Juni 1814 eene partij gaf, daarbij o.a. verschenen de Lieut. Governor, diens echtgenoote en de Members of Council!

2. Anna Gerardina, geb. te Malakka, trouwt te Bat. 25 Maart 1810 met J. A. Steijn Parvé van 's-Gravenhage;

3. Catharina Elisabeth trouwt 13 Febr. 1814 August Jan van Kerst van Havezaate bij Kampen, Chirurgijn Majoor, eerder geh. met E. J. W. Domis van Bat.; zij hertrouwt 4 Sept. 1815 met Willem Nic. Servatius, wedr. van Sara Cath. Senn van Basel; hij overlijdt als Resid. der Preanger 24 Nov. 1827;

4. Jacobina Maria trouwt 19 Juli 1812 den Eng. Luitenant John Tulloch, First Assistant in the Treasury; hij wordt Proc. 15 Aug. 1815 Civil Paymaster op 1.000 Java Roep. Uit dit echtpaar wordt 15 Sept. 1813 gedoopt Stamford William Raffles Tulloch.

Cranssen (Willem Jacob), geb. te Wedde in Groningen, een van de Groningers, die met of door Alting naar boven kwamen (de beide Engelhard's, Muntinghe e.a.). Werd door Daendels afgezet als Gouverneur van Ambon; was bij de verovering Presid. van Schepenen en bleef dit, toen hij bij Order van den G.-G. d.d. 18 Oct. 1811 tot derde lid in den Council werd benoemd op $500 \$$; tot het einde van het $\mathrm{Br}$. bestuur is hij derde lid gebleven, terwijl nieuwe leden op den tweeden stoel zitting namen. Bij de opheffing van het Schepencollege werd C. bij publicatie van 21 Jan. 1812 President der Bench of Magistrates te Bat. op 500 \$ (later 1760 Java Roep.) en Superintendent van het Court of Requests op $300 \$$; in laatstgenoemde betrekking ontslagen bij schrijven van 31 Mei 1813, doch bij publicatie van 28 Mei 1813 benoemd tot Presid. Commercial Committee op 300 \$. Proc. 28 Oct. 1814 wordt hij President Revenue Committee. Was met Romswinckel e.a. eigenaar van Tegalwaroe en Soemedangan, met Nic. Engelhard e.a. van Pondokgedeh, Tjilembar, Tjiawi en Tjisaroewa, evenzoo van Tjiomas, Tjitjoeroek, Dramaga en Sindangbarang; heeft ook den eigendom bezeten van de landen Krokot, Tjinere en Maroejoeng, later ook van Pasar Weltevreden. Woonde in 1813 op Jacatra; had echter ook eene woning op Noordwijk, waar later het Hotel Wisse was. Een bekrompen mensch van geringe bekwaamheid, beter op zijne plaats in het Commercial Committee dan in den Council; steeds geweldig breedsprakig in kreupel Engelsch (dagloon noemt hij: dayloon; brandmeester: brandmaster

D1. 92. 
enz.); als landheer een pertinent bestrijder van alle gouvernementsbemoeiing en verbetering, en daardoor (evenals ook door zijne herhaalde passeering in den Council) in den laatsten tijd van het $\mathrm{Br}$. bestuur op nogal kwaden voet met den Lieut. Gov. Overigens gaarne poseerend als Orangist en Engelschgezind; vroeg blijkens Gaz. 12 Maart 1814 naturalisatie aan als Engelschman. Na de publicatie op 24 Mei 1814 van het bericht, dat de Prins van Oranje in Nederl. terug is, organiseert $\mathrm{C}$. eene nationale demonstratie, waaraan Raffles deze wending geeft, dat eene afdeeling van het Bijbelgenootschap wordt opgericht; op den feestdag 24 Aug. (verjaardag van Willem I) geeft $C$. eene partij, en twee dagen later nogmaals eene.... ter herdenking van de verovering van Meester Cornelis door de Eng. In Maart 1816 roept eene commissie, waarin ook C., de menschen op tot bijdragen voor het fonds tot aanmoediging van den gewapenden dienst in Nederl.; de hoogste inschrijver daarbij was C. met eene gift van 4.000 gulden, totdat Van Gesseler te Lintelo hem de lcef afstak met eene van 4.200. Hij overleed op Pondokgedeh 17 Aug. 1821, oud 58 jaar. Zijne vrouw Maria Eleonore Hartman was misschien de weduwe C., die einde 1833 naar Nederl. ging. Uit dit huwelijk de zoon Willem Leonard, gehuwd 17 Dec. 1817 met Wilhelmina Jacobina Burghgraaf van Makassar; hij overlijdt in 1827; voorts de dochter Rica Catharina, die P. T. Couperus huwde (zie aldaar). Bij zijne huishoudster Wilhelmina Jacoba Nesnarc (overl. te Bat. 27 Juli 1848; bezat een groot huis op Noordwijk) had C. de geadopteerde dochter Wilhelmina Nicolasina Cranssen, geb. op Ambon, die 30 Juli 1820 trouwde met Karel Lodewijk Blume van Brunswijk. Dit huwelijk moet door scheiding zijn ontbonden, want ofschoon Blume eerst in 1862 overleed, trouwde zij den 22 Sept. 1830 met Mr. P. Merkus, uit welk huwelijk in 1834 een zoon werd geboren; zij overleed in den Haag 19 April 1848. Een W. J. Cranssen, die Proc. 14 Mei 1816 benoemd werd tot Assistent Registrar to the Bench of Mag., zou een tweede adoptiefkind kunnen zijn.

Crazufurd (John), geb. 1783, studeerde te Edinburgh in de medicijnen; wordt nog in 1815 aangeduid als Assistant Surgeon. Diende eerst in Bengalen. Werd in 1808 benoemd bij den geneeskundigen dienst te Penang, leerde daar Maleisch en ging met de expeditie naar Java; in Sept. 1811 is hij Malay translator, doch vertaalde ook uit het Javaansch; bovendien fungeerde hij in Sept. en Oct. 1811 als waarnemend Secretaris van Lord Minto, die zijne superior talents 
vermeldt. Den 25 Oct. 1811 geeft de Regeer. den Nederl. Minister te Djokja kennis, dat hij door C. zal worden vervangen (conform General Orders van 24 Oct.), hetgeen op 15 Nov. 1811 plaats vond. Zijn salaris was $750 \$$ benevens $250 \$$ commissiegeld van de revenues collected. Hij trad direct zeer scherp tegen den Sultan op. Na den val van Djokja (Juni 1812) was hij werkzaam in Patjitan (Aug. 1812), waar hij het landrentestelsel invoerde; den 10 Sept. 1812 begon hij zijn onderzoek in Kedoe, hetwelk hij vóór het einde van dat jaar voltooide. Uit de zonderlinge geschiedenis (Proc. 22 Oct. 1813) van den dwangkoop van lijnwaden der Compagnie door inl. Hoofden in Kedoe en anderen, waarbij Crawfurd's naam werd gebruikt, schijnt te blijken, dat hij destijds op den Javaan, speciaal diens gevoeligheid voor prentah aloes, heel weinig kijk had. Bij schrijven van 28 Jan. 1813 ontbond de Regeering de Commissie voor de overname der afgestane Vorstenlanden; den 27 Febr. 1813 trad Lawrence op als Resident van Kedoe. Den 24 April 1813 vertrok Crawfurd van Djokja (waar hij Homer in charge liet) naar Bat. en kwam daar 5 Mei met zijne vrouw (die 21 Oct. naar Engeland vertrok) aan, waarop Raffles hem 27 Mei opdroeg, de onlusten in den Oosthoek te dempen en den aard daarvan als Commissaris te onderzoeken, eene opdracht, die aan Hope groote ergernis gaf. Komt 3 Juni te Probolinggo; ontvangt bij schrijven van 13 Juni den last, zoowel dit als Bezoeki van de Chin. eigenaren over te nemen en daarna naar Cheribon te gaan. Den 24 Juni geeft hij Prob. en Bezoeki over aan Cotes en vertrekt 26 Juni. Komt 4 Juli te Bat.; bij proclamatie 19 Juli 1813 wordt zijne benoeming tot Commissaris voor de landrente ter kennis van de bevolking van Cher. gebracht. Daarna verricht hij den aanslag der landrente in Cheribon en is in December te Djokja terug. Den 23 Jan. 1814 wordt hij aangewezen om te Samarang Resident Eales te vervangen; hij bleef hier tot 12 April, maar was onderwijl nu en dan ook te Djokja als Resident en had tevens eene opdracht gekregen als Political Assistant van Nightingall, dien hij thans eerst naar Bali en vervolgens naar Makassar begeleidde; in de Gaz. 16 Juli en 31 Dec. 1814 wordt zijn aandeel in de expeditie (val van Boni 7 Juni 1814) geprezen. Den 5 Juli 1814 nam hij zijne residentie weder over van Eales, die haar intusschen had waargenomen; wordt bij schrijven van 26 Aug. 1814 benoemd tot Resident van Soerabaja en Bangkalan; geeft 20 Sept. Djokja over aan Garnham en neemt 1 Oct. Soerabaja over van Burney. Zijn salaris als Resident aldaar was 1.500 Java Roep. Proc. 10 Aug. 1815 wordt hij 
benoemd tot Resid. te Samarang op zijn tegenwoordig salaris ,and allowance"; neemt deze residentie 18 Sept. over van W. Ainslie. Wordt diezelfde maand in de commissie benoemd voor de verdeeling van de residentie Djipan en Grobogan. Het jaarboekje van 1816 noemt hem Resident and Magistrate te Sam. Geeft 20 Jan. 1816 Samar. over aan Bidwell en neemt 22 Jan. de residentie Djokja over van D. Ainslie; zijne benoeming tot. laatstgenoemde residentie staat Gaz. 27 Jan. Hij bleef hier Resident tot de teruggave; wachtte den terugkeer der Nederl., aan wie hij (volgens Hardy) een hekel had ${ }^{1}$ ), echter niet af, maar vertrok een paar dagen te voren en liet de overgave verrichten door zijn Assistant E. Taylor. Vervolgens bleef C. nog eenigen tijd te Samarang als Commissioner tot het afdoen van hangende zaken (Gaz. 19 Aug. 1816).

Met Raffles stond hij niet steeds op goeden voet. Zoozeer als C. een voorstander was van de landrente, zoo afkeerig was hij van de middelen om die belasting hooger op te drijven en met dwang te innen. Zin voor studie hadden zij gemeen, maar $C$. was veel beter deskundige dan $\mathrm{R}$. en deelde zoo weinig diens ingenomenheid met de letterkunde der Javanen, dat hij (ten minste, ik weet niet wie het anders kan wezen) in Gaz. 28 Maart 1812 verklaart, dat ,their literary efforts are wonderfully feeble and puerile, and that too when compared with those of their neighbours, the western nations of the continent of Asia". Dit stemt volkomen overeen met het minachtend oordeel, dat C. elders (History II, 21; 26; 37; 294; 298; $300 ; 320)$ steeds velt over de Jav. letterkunde en geschiedschrijving; zelfs kiest C. hierbij (zonder hem te noemen) partij tegen Raffles, door te zeggen dat zijn eigen streven is om de Javanen te schetsen as they actually are and not to draw attention to them (zooals Raffles, de man der reclame en der Turksche trom, deed). Evenzeer komt hij op tegen Raffles' manie om voor de geschiedschrijving van Java bijna alleen inlandsche bronnen te gebruiken en diens verklaring van oud-Javaansche opschriften. Maar R.'s ingenomenheid met den Javaan zelven deelde C. Zoo spreekt hij in 1815 van diens prevalent candour; evenzoo vinden we bij hem (History III, 90) de zonderlinge bewering: ,There are no people who have a more sacred regard

1) Daarom is het zeer kenschetsend, dat Raffles hem bij zijne benoeming tot Resident van Soerabaja voorschrijft: to conciliate the Dutch inhabitants and to respect most scrupulously the Colonial institutions and regulations in as far as they may not have been expressly superseded by the orders of the existing Government. 
for the sanctity of an oath" (dan de Javanen). In zijn later werk, de Dictionary, bl. 173, spreekt hij meer bezadigd, en verklaart enkel den Javaan voor den eerlijksten Aziaat dien hij kent.

Wat degelijkheid zoowel van kennis als van karakter betreft, was Crawfurd zeer beslist de meerdere van Raffles. Diens humbug, diens cant, diens windmakerij is hem volstrekt vreemd. Zoo was hij de man, die te Singapore de slavernij tegenging, welke door $\mathrm{R}$. daar was ingevoerd en bevorderd (Thomson bl. 207). In zijne History of the Indian Archipelago onthoudt C. zich in den regel van het geschimp op de Hollanders, waaraan R., die te voren zoo lief tegen hen had gedaan, zoo lustig toegaf, en erkent royaal de vele fouten der Engelsche O. I. Compagnie, waarover de meer politieke R. placht te zwijgen als het graf. Den 4 Sept. 1816 schrijft de Resid. van Sam., dat C. hem eene bevolkingsstatistiek van dat gewest heeft gevraagd, daar hij ,beezig is een beschrijving van het eijland Java te vervaardigen". Bij het hof van Djokja was hij zeer gezien. Dat paarden van hem aan wedrennen meedoen, lezen wij Gaz. 29 Sept. 1815; 23 Maart 1816. Zeer karakteristiek is een schrijven van hem van 10 April 1814: de Kapitein-Chinees te Samarang zegt, dat ik hem met een zakdoek heb geslagen; dat kan wel zoo wezen, but had I been inclined to inflict corporal punishment upon him, some more offensive weapon would have been chosen, nor, allowing for the peculiar manners of his country, will anyone consider that, even had matters proceeded to that extremity, the complainant had been very poignantly insulted. Hij schijnt dus voor Chineezen de grootste minachting te hebben gevoeld; niettemin was hij (History II, 463) sterk vóór kolonisatie met Chineezen in den Archipel. In later dagen is hij Resident van Singapore geweest. Abdullah (bij Thomson pag. 191) vindt Crawfurd blijkbaar een prul-Resident. Thomson p. 192 schrijft dit toe aan Abdullah's liefde voor Raffles. Abdullah zegt van hem (ib. pag. 208), dat hij te Singapore ook goed voor zich zelf zorgde; , he was impatient and of a quick temper; but in what he was engaged he did slowly and not immediately .... he was a man of good parts, clever and profound.... he was much bent down by a love for the goods of this world. His hand was not an open one, though he had no small opinion of himself; was zeer ongeduldig bij het hooren van klachten en het onderzoek van zaken. Volgens Thomson p. 209 is dit oordeel over C. niet onjuist.

Een D. Crawfurd (een koopman) wordt Proc. 2 Febr. 1816 be- 
noemd tot Magistraat te Bat; Donald C. overlijdt te Bat. 8 Juli 1817. Volgens Campbell (I, 476) was James Crazufurd, die in 1820 te Samarang overleed als deelgenoot in Deans, Scott and Co., een broeder van John.

Dalgairns $(J$.) neemt als Luitenant deel aan de bestorming van Meester Cornelis (Conquest p. 19) en eischt 20 Sept. 1811 Soerabaja op. Febr. 1813 is hij Commandant van het Amboynese Corps, evenzoo in 1814 en 1815; wordt 24 Maart 1814 aangewezen tot waarnemend Town Major te Bat. en Aide-de-camp van den Lieut. Gov., ter vervanging van Travers; was als Town Major Commandant van het Burghercorps. Bij Travers' terugkeer uit Europa treedt deze weer op als Town Major en krijgt ook het commando over het Amb. corps, terwijl D. (Gaz. 19 Aug. 1815) Honorary Aide-de-camp wordt. Proc. 10 Aug. 1815 wordt hij Sub Treasurer op 2.000 Java Roep. p.m. en Proc. 3 Nov. 1815 lid van het Revenue Committee. Te zijnen huize werd 24 Maart 1816 het afscheidsdiner aan Raffles gegeven. Hij teekent ook het afscheidsadres van R.'s persoonlijke vrienden, Gaz. 6 April 1816. Fendall bevestigde hem als Honorary Aide-de-camp, Gaz. 20 April 1816. Een paar malen wordt zijn rang aangegeven als zijnde Captain, maar het zal wel steeds dezelfde persoon zijn.

Dalton (D. H.), Major, neemt deel aan de operaties tegen Meester Cornelis en die tegen Djokja (Conquest p. $19 ; 72 ; 181 ; 194$ ). Wordt bij General Orders 28 Juli 1812 benoemd tot commandant ,,at Klatten and in the provinces of the Native Princes"; houdt 11 Dec. 1813 eene oefening van the light infantry battalion te Djokja, alwaar hij thans commandant was, in tegenwoordigheid van Raffles, die hem zijne goedkeuring te kennen geeft (Gaz. 1 Jan. 1814), hem benoemt tot Superintendent of the roads and bridges in de Vorstenl. op 500 Java Roep., en hem belast met de „superintendence” der corpsen van Prangwedono en Pakoealam (Gaz. 8 Jan. 1814). Doch reeds Gaz. 20 Aug. 1814 worden deze beide opdrachten ingetrokken. Proc. 15 Aug. 1815 wordt D. benoemd tot Resid. en Commandant te Makassar, waarheen hij 5 Sept. 1815 van Batavia vertrekt, en waar hij 3 Oct. 1815 optrad als vervanger van den Acting Resid. Captain Wood; hij bleef dit tot de teruggave. Een verstandig man met ruimen blik. Zie ook V. d. Kemp, Herstel p. 309. 
Davidson (J.) (zijne vroegere qualiteit blijkt nergens) wordt bij besluit van 21 Oct. 1811 Acting Assist. Secretary to Govt. op 375 \$. Wegens ziekte van Robison wordt hij Proc. 23 Nov. 1811 Acting Secretary; toen Robison ontslag vroeg, werd D. bij Proc. 11 Jan. 1812 opnieuw Acting Secretary op 1.000 \$, tot hij Proc. 10 April 1812 deze betrekking moest overgeven aan Blagrave en terugtreden tot die van Acting Deputy Secr. op 500 \$. Reeds in April 1812 (acte Piepers no. 701) kocht hij voor 60.000 Rds. papier een groot huis op Rijswijk. Den 20 Mei 1812 werd hij benoemd tot provisioneel Landdrost van Buitenz. op $300 \$$ en bovendien tot waarnemend Assistant in the Lt. Governor's office op 200 \$; den 30 Mei nam hij het bestuur over van Couperus; wordt Proceed. 30 Juni 1812 beëedigd als Landdrost van Bz. Raffles, die toen op reis was, schreef 16 Juli dat de beide Assistant Secretaries met 1 Aug. worden afgeschaft en benoemde tevens Macquoid tot Landdrost van Buitenz.; deze bleef echter voorloopig in O. Java. Proc. 9 April 1813 wordt D. benoemd tot Civil Paymaster and Storekeeper te Samarang op $300 \$$ (vermoedelijk was hij dit reeds vóór dien datum); doch reeds 27 April 1813 wordt hij benoemd tot Resident van Rembang op 300 \$; hij nam deze residentie 7 Mei over van Hartilieff. Proc. 10 Aug. 1815 wordt hij benoemd tot Resid. van Probol. en Bezoeki; hij geeft Rembang over aan zijn opvolger Flint 1 Sept. 1815, en neemt 20 Sept. zijne nieuwe resid. over van Davis. Hij bleef dezen post bekleeden tot de teruggave.

Een John Davidson uit Schotland kwam 14 Maart 1813 met verlof van Bombay op Java; hij vroeg ontslag uit den dienst en werd bij advertentie van 12 Febr. 1814 opgenomen in de firma Shrapnell and Co., die nu zou heeten: Shrapnell, Skelton and Co., (zie sub Macquoid); volgens Campbell I, 493 was hij een bloedverwant van den Resident. Volgens denzelfde (ib. p. 498) trouwde eene dochter van den Resident met H. A. C. Smissaert; hij is zeer verward daarover, zie ib. p. 435 en II, 929. Emma Davidson echter, die 16 Dec. 1835 te Pasoeroean met H. A. C. Smissaert trouwde, zal wel eene dochter zijn geweest van den beneden volgenden John.

Een Philip Davidson krijgt 1 Maart 1816 van zijn naamgenoot den Resident, die een familielid van hem was (Proceed. 1 Maart 1816), een licent tot houtkap in de bosschen van diens residentie. Blijkbaar vonden deze Schotten ons Java een goed land. Philip Davidson is 1819 handelaar te Samarang; in 1824 te Soerabaja. In 1823 heeft een John Davidson twee suikermolens in Probo- 
linggo. In 1824 heeft een John Davidson een huis en winkel te Samarang. Een John Davidson overlijdt te Pasoeroean 13 Mei 1850, oud 71 jaar.

Davics $(W$.$) wordt herhaaldelijk, ook door de Regeering, verward$ met Luitenant C. E. Davis.

Komt Proc. 10 Oct. 1812 voor als Assistant and Indexer op het Secretary's Office op 200 \$; wordt Proc. 9 April 1813 First Assistant op dat bureau en Examiner op hetzelfde salaris; den 16 Juli 1813 benoemd tot Assistant van Crawfurd bij den a.s. aanslag van Cheribon. Den 24 Sept. 1813 benoemd tot Assistant to the Resident van Tegal for settling the revenues of that District; als Acting Assistant Resident van Tegal wordt hij Proc. 22 Oct. 1813 benoemd tot Acting Deputy Collector of Customs te Samarang, welke betrekking hij 20 Nov. overnam als vervanger van Boggie, en 2 Mei 1814 overgaf aan Loudon, om naar Tegal te vertrekken als Assistant van den zieken Resident Keasberry, die echter reeds overleden was, toen Davies dienzelfden dag daar aankwam. Hij bleef nu waarnemend Resid. van Tegal, tot hij dit 22 Aug. 1814 kon overgeven aan Homer om weder naar Cheribon te gaan, alwaar hij volgens last van $30 \mathrm{Juli}$ den nieuwen Resident Davy zou bijstaan in the Revenue arrangements; hij arriveerde aldaar 30 Aug. 1814 en trok er 350 \$, welk salaris Proc. 14 April 1815 werd verhoogd tot 600 (sic) Java Roep. wegens zijne goede diensten ,in establishing the recent detailed settlement in those districts”, d.w.z. wegens de geweldige opdrijving van den aanslag der landrente, waarover weldra zoo geklaagd werd. Den 21 Juni 1815 neemt hij de residentie Cher. over van Davy en treedt dus op als waarnemend Resid., tot hij haar den 20 Aug. 1815 overdraagt aan Hanson. Proc. 10 Aug. 1815 was hij benoemd tot Assistant to the Resident of Rembang, in het bizonder voor de landrente, op 800 Java Roep.; hij aanvaardt deze betrekking den 22 Sept., en helpt Resident Flint bij den aanslag. Den 1 Mei 1816 nam hij Djipan over van $P$. van Teijlingen en bleef aldaar tot in Augustus te Bowerno, in temporary charge of Jipan, als Assistant Resident.

Davis (C. E.), Luitenant, wordt (ook in officieele stukken) dikwijls verward met $W$. Davies, die geen officier was.

Wordt bij schrijven van 15 Sept. 1813 tot Resident van Banjoewangi benoemd; treedt als zoodanig op 17 Sept.; wordt 2 Nov. 1813 toegevoegd aan Hopkins, bij wien hij reeds was, tot het verrichten 
van den aanslag op 150 \$; was van 16 Oct. tot eind Dec. 1813 derhalve Assistant Commissioner of Revenue in Probolinggo; werd bij schrijven van 24 Jan. 1814 benoemd tot Collector of the territorial revenues in Banjoewangi, en was aldaar, sedert de afzonderlijke residentie Banjoewangi bij schrijven van 24 Febr. 1814 was hersteld (zie onder Garnham) tevens Resident en militair commandant; als zoodanig verslaat hij 26 Febr. 1814 een bende gelande Balineezen met verlies van driekwart van hun volk en alle booten op eene na. Den 11 Oct. 1814 wordt hem opgedragen, den geschorsten Roxburgh te gaan vervangen; 1 Nov. geeft hij nu zijne residentie over aan $\mathrm{O}$. Holst de Weerth en neemt 3 Nov. de betrekking van Resident en Collector van Bezoeki over. Bij schrijven van 10 Dec. 1814 wordt hij benoemd tot Collector of Revenue of the Besukie districts; bij een tweede schrijven van $12 \mathrm{Dec}$. wordt hem echter de opdracht verstrekt om zich naar Boeleleng te begeven ten einde een brief over te brengen aan D. Ainslie, met wien hij vermoedelijk terugkeerde, want den 7 Jan. 1815 geeft hij Bezoeki en Prob. als waarnemend Resident over aan dezen D. Ainslie en 13 Jan. aan denzelfde zijn ambt van Collector aldaar om opnieuw naar Bali te gaan. Den 24 Febr. 1815 bericht hij zijn terugkeer en de geschiede wederopneming van zijn collectorschap in Bezoeki; bovendien trad hij van 14 Juni tot 20 Sept. 1815 bij afwezigheid van den Resid. aldaar weder als diens plaatsvervanger op en gaf toen de residentie over aan J. Davidson. Zijn salaris als Collector was 1.000 Jav. Roep. Hij bleef dit ambt bekleeden tot de teruggave. Volgens Campbell I, 626 was hij in 1827 Captain bij de Garrison Staff te Singapore; volgens Thomson p. 127 schoonzoon van Colonel Farquhar aldaar.

Davy (Captain L. H.). Den 8 Nov. 1811 schrijft Gibbs te Soerabaja: „I wish to have Captain Davy of the 4th Bengal Volunteer Battalion appointed my Secretary; he reads, writes and speaks the Malay language”. Hij wordt nu Proc. 23 Nov. 1811 benoemd tot G.'s Assistant and translator op 150 \$, welke toelage Proc. 4 Jan. 1812 blijkt $200 \$$ te bedragen. Zijn titel was Assistant Deputy Commissioner; hij zat als zoodanig in den weg van Goldbach, die o.a. over zijn gebrek aan ijver klaagde. Den 7 Juli 1812 verving hij Assey als waarnemend Deputy Civil Commissioner, als hoedanig 5 Aug. 1812 Adams optrad, wiens Assistant hij dus weer werd. Hij bleef dit ook nog, nadat hij 2 Sept. 1812 was benoemd tot civiel gezaghebber of Resident te Bangkalan op 200 \$, terwijl hij in eerst- 
genoemde betrekking $100 \$$ had; de plaatsing was geschied op bizonder verzoek van den Sultan van Madoera, wiens vriend hij was; hij woonde echter te Soerabaja en had geen militair gezag. Adams verzocht 24 Sept. 1813, dat hij als Deputy Resident van Soerabaja speciaal mocht worden belast met het bestuur over de stad en ommelanden. Uit een schrijven van Adams dd. 30 April 1814 blijkt, dat D. tevens Magistrate was en belast met de kas; bovendien was hij nog steeds Resid. van Bangkalan. Toen Adams 2 Mei op expeditie ging, gaf hij de residentie Soerabaja over aan D. tegelijk met het militair commando; den 25 Mei was hij terug, waarop de Regeer. bij schrijven van 30 Juli 1814 D. benoemde tot Resident van Cheribon, als hoedanig hij 27 Aug. optrad; hij had er geen militair gezag. Hij maakte zich te Cheribon berucht door een enorm hoogen aanslag der landrente, doch gaf reeds 21 Juni 1815 de residentie over aan zijn Assistant W. Davies, om met verlof naar Europa te gaan; den 9 Aug. 1815 ging hij te Bat. onder zeil.

Uit Raffles, History II, 59 blijkt, dat hij op diens verzoek met hulp van den Panembahan van Soemenap drie Jav. inscripties vertaalde; ook uit bewaarde translaten ziet men dat hij Javaansch verstond.

Deans (John, ook geschreven Ino) wordt bij besluit van 28 Dec. 1811 benoemd tot Assistant to the Resident at Djocja op 200 \$. Proc. 5 Jan. 1813 wordt zijn verzoek om ontslag als zoodanig ingewilligd. Had hij zich verdienstelijk gemaakt bij de verovering van den kraton (Conquest p. 197), den 11 Dec. 1813 wordt zijn verzoek toegestaan om in Djokja eene indigofabriek op te richten; den $1 \mathrm{Mei}$ 1814 teekent hij met een Chinees een contract als opiumpachters in de Djokjasche Sultanslanden en Patjitan. Hij was toen geassocieerd met Robert Scott te Samarang, ja, blijkens eene klacht van Lawrence had hij reeds als Assist. Res. tabak laten opkoopen in Kedoe om die aan Scott te zenden. Niettemin spreekt Crawfurd in Proc. 22 Oct. 1813 van zijne scrupulcus rectitude and integrity. Over het dienstjaar 1 Mei 1814-1 Mei 1815 hield het huis Deans and Scott de opiumpacht van Samarang, evenzoo over 1816/17. Den 20 Aug. 1814 wordt hem de vergunning geweigerd om verder in de Vorstenlanden te verblijven of aldaar handel te drijven. In 1819 gaat John Deans uit Deans, Scott en Co. Er blijven in: Robert Scott, J. P. Macdonald, James Crawfurd, Robert Morris en Charles Harris onder denzelfden naam van Deans, Scott en Co. Met ingang van 1 Jan. 1821 hief 
deze firma hare kantoren te Samarang en Soerabaja op, en in den loop van dat jaar werd zij ontbonden. $\mathrm{Nu}$ beginnen John Deans, Robert Scott en Robert Morris de firma Deans en Co. Door het uittreden in 1823 van Scott en Morris bleef alleen Deans er in, en met 31 Dec. 1826 wordt zij opgeheven. Daarop ging Deans naar Europa, maar in 1828 associeert hij zich te Bat. met Maclaine Watson, onder wiens naam de nieuwe zaak wordt gedreven. Den 11 Dec. 1825 was D. te Bat. gehuwd met Margaret Cameron Hodges, de dochter van een koopvaardijkapitein. Crawfurd (History III, 522 noot) vermeldt hem als ,my acute and intelligent friend”, die hem aan gegevens had geholpen betreffende den handel in den Archipel.

Decker (P.), gewezen Resident te Bantam, een „mesties” (Dr. de Roo I, 326), echter te Haarlem geboren, huwde 1811 Petronella Michiels, weduwe van F. W. Houtman en een familielid van den landeigenaar Augustijn Michiels; was bij de verovering Secretaris, Kassier, Boekhouder en Pandbewaarder der Bank van Leening; wordt Proc. 23 Nov. 1811 in salaris gelijkgesteld met de Commissarissen dier Bank. Bovendien blijkt Proc. 1 April 1812 dat hij translateur voor het Jav. was (en wel de eenige te Bat.) op 100 \$; zijn gansche personeel bestond uit een klerk op 8 \$ en twee schrijvers à 5 \$. Hij klaagt 29 Aug. 1814, dat hij met dit sobere personeel thans is geschrapt, en dat Adimonggolo op 600 Java Roep. plus 300 Java Roep. voor personeel thans met het werk is belast. Hij overleed 19 Nov. 1814.

Dillon (J.), Lieutenant, werd gewond bij den aanval op Meester Cornelis (Conquest p. 68). Proc. 14 Febr. 1812 benoemd tot Paymaster and Storekeeper te Soerab. op 200 \$; wordt geschorst 23 Nov. 1813. Bij schrijven van 11 Jan. 1814 benoemd tot Vendumeester aldaar op 300 Java Roep. Proc. 21 Oct. 1814 benoemd tot Superintendent of public buildings te Soerab.; Proc. 14 April 1815 als zoodanig ontslagen wegens opheffing dier betrekking; hij bleef nog steeds Vendumeester. Gaz. 30 Maart 1815 bevat zijne benoeming tot Assistant to the Resident at Cheribon, waar hij echter reeds 7 Maart was aangekomen om die betrekking te vervullen.

Een captain Dillon vertrok van Bat. naar Calcutta 6 Sept. 1815. Of deze soms met den Lieut. kan verward zijn bij een van bovenstaande benoemingen is niet zeker. 
Dixon (John), scheepsbouwer te Lasem, gaat begin 1817 naar Europa. Overlijdt te Rembang 14 April 1824.

Domis (H. J.) van Alkmaar (denkelijk verwant aan Magdalena Clementia Domis van Samarang, de vrouw van P. Engelhard), kwam op Java 10 Mei 1807, trouwde 4 Aug. 1811 Sara Francina Waterloo, dochter van den Resid. van Cheribon, en was bij de komst der Engelschen Adjunct Inspecteur over de Koffiecultuur; toen Winckelmann als Inspecteur ontslag vroeg, beval hij 16 Oct. 1811 D. aan voor opvolger; deze werd dan ook Provisional Superintendent of coffee culture in the Samarang district op 200 \$, totdat Hope hem 8 April 1812 zijn ontslag meedeelde. Gaz. 4 April 1812 bevat zijne benoeming tot Fiscaal der Houtbosschen; het salaris was 200 \$. Bij schrijven van 24 Mei 1813 benoemt de Regeer. hem tot lid der Weeskamer te Samarang; het salaris beliep 100 \$. In Mei 1816 treffen wij hem aldaar als Acting Ass. to the Resident. Wordt 1819 Inspecteur van Financiën. Eenige jaren later werd hij Resident te Samarang, zie levensbeschrijving in Encycl. van N.-I. Zijne tweede vrouw was C. A. Palm. Hij overleed te Brummen 7 Mei 1842, oud 60 jaar.

Doornik (Mr. Joh. Adr.), geboren in 1764 te Eisch, Esch of Eschma bij 's Bosch, kwam op Java 1798 als lid van den Raad van Justitie; trouwt te Bat. in 1800 met Theodora Corn. Hendrika Keijzer van Joana; hare zuster trouwde in 1804 met H. Tilenius Kruijthoff. D. is het type van een Compagniesdienaar met protectie (naar het schijnt van den ouden Siberg), zelfs niet in staat om behoorlijk Hollandsch te schrijven, laat staan Engelsch, zoodat hij hardnekkig met de Eng. Regeer. bleef correspondeeren in zijne moedertaal. Op 28 Dec. 1812 zendt de uil zoowaar een langen nieuwjaarwensch in het Nederl. aan den Lieut. Governor. Op eene vraag 19 Juli 1813 van den Scriba te Joana, wat er gedaan moet worden om de nieuwe ongewilde duiten gangbaar te maken, antwoordt deze held in margine: „Een helder pak op den bazaar”. Den 30 Mei 1813 schrijft hij aan de Regeer. naar aanleiding van eene vermindering van zijn traktement: Ik zal ,,eene verdubbelde aanstrenging van ijver trachten aan den dag te leggen, teneinde in Uwer Excellentie hooger dan geldswaarde geschatte goedkeuring mijne beloning te vinden”. In April 1812 moet hij eene gevangenis inrichten en stelt nu voor, daartoe eene mesigit te gebruiken, welke de Regent bezig is te bouwen; 
van vergoeding geen woord. In Juni 1815 heeft hij een plan om te laten vaccineeren door oude wijven.

Bij de komst der Eng. was hij Oud-Advocaat-Fiscaal, Landdrost van Pekalongan; Janssens betuigde hem zijne ontevredenheid over zijne laksheid in die dagen. Toen in Nov. 1811 Van Haak werd afgezet als Landdrost van Japara, werd zijn collega D. tot zijn vervanger benoemd, die 29 Nov. als zoodanig optrad; zijn salaris was $350 \$$. Hij is dit gebleven gedurende het gansche Eng. bestuur; 18 Juli 1816 besloten ook Comm.-Gen. om hem voorloopig te handhaven; hij was nog in 1820 Resident van Japara en is Res. van Jap. en Joana gebleven tot 1823. Doch in Sept. 1813 belastte Raffles niet hem maar Eales met den aanslag der landrente in zijn gewest; wel bepaalt Raffles den 18 Jan. 1814 een salaris van 500 \$ voor den „Resident and Collector”, maar in Maart 1814 is Macquoid aldaar als Collector werkzaam; in 1814 wordt Heyland met den aanslag belast, die dan ook bij zijne correspondentie met de Regeer. over dergelijke zaken den Resident eenvoudig negeert; 17 Mei 1815 schrijft de regeer. aan D. dat een English Assistant, Mr. Brown, has been recently appointed to your Residency, zoodat hij nu met diens hulp in het Engelsch zal moeten correspondeeren; hij krijgt nog eene zure vermaning om meer attent te zijn; van de landrente heeft hij alleen de inning te verrichten. Niettemin werd in Juli 1815 zijn salaris gebracht op 1.200 Java Roep. Raffles heeft hem een monument gesticht, door in zijne History (I, 254) 's mans rapport anno 1812 over den Javaan te vermelden als ,amusing” door bekrompenheid. Zie ook Van der Kemp, Herstel p. 238.

Doorninck (Mart. van), geb. te Deventer 1787, waarschijnlijk verwant aan R. G. van Polanen (Dr. de Roo II p. 126), kwam op Java 13 April 1808; was in Juni 1811 Adjunct Eerstgezworen klerk ter Secretarie der H. Regeering, translateur in de Fr. en Eng. talen en boekhouder van 's Lands drukkerij. In April 1812 vinden we hem als Second Assistant op het Dutch translator's office op 150 \$, in Oct. 1812 als Dutch translator op het Secretary's office op hetzelfde salaris. Bleef op de Secretarie tot wij in Gaz. 4 Juni 1814 zijne benoeming vernemen tot Assistant to the Resident of the Environs. Bij de herhaalde afwezigheid van Resident W. Ainslie trad v. D. reeds van 1 Juli tot 4 Oct. 1814 als waarnemend Resident der Ommel. op; ook daarna moest hij telkens voor zijn chef invallen, totdat hij de residentie 14 Jan. 1815 overgaf aan Methven en weer 
Assistant Res. werd. Hij dateert zijne brieven in den regel van Bidaratjina. Dit was zijn eigendom. In Oct. 1815 en later vinden we hem in die qualiteit te Buitenz. als opvolger van Van der Poel. Maakt den indruk van een bekwaam man. Huwde te Bat. 15 Nov. 1813 met Jacoba Wilhelmina Bremer, waaruit gedoopt 2 Juli 1820 Charlotte Johanna Marguerita en 17 Maart 1822 François Hendrik Izak Martinus. Wordt 1819 Ass. Res. van Politie van Batavia. Hij hertrouwde met J. W. von Gutzlaff. Overleed vóór 1821.

Adelaide Louise van Doorninck is 1833 de vrouw van J. S. M. Neitzell te Tjiandjoer.

Dragheim. (G.) was einde 1810 Onderhavenmeester te Soemenap; wordt aldaar in Nov. 1811 Drost; soms heet hij Resident; zijn salaris was 100 \$. Den 12 Oct. 1812 droeg Adams echter (daar een Drost of Resident te Soemenap niet in de formatie was opgenomen) zijne werkzaamheden op aan Garnham, die het militair gezag over het gansche eiland Madoera voerde. Toen Garnham echter te Samarang als vervanger van Lawrence optrad, gelastte de Regeer. aan Dragheim bij schrijven van 4 Nov. 1812 om de ,civil duties” te Soemenap weer op zich te nemen, die hij 18 Nov. 1812 aanvaardde, maar reeds den 13 Jan. 1813 overgaf aan Clark. Bij Proc. 22 Jan. 1813 werd hem voor die waarneming 250 Sonat Rup. p.m. toegelegd.

Zijne vrouw heette C. J. van Houten.

Drognat (J.T.), gewezen Eerste Luitenant der rijdende artillerie, is 1812 en 1813 onder Cornelius werkzaam als landmeter tweede klas, opnemer en teekenaar; was Juni 1813 bezig aan het teekenen van ,the large geographical chart of Paccalongang”; wordt 14 Juli 1815 met zijn assistent Kram belast met de opneming en kaarteering van Toeban, waarmee hij in Sept. 1816 nog bezig was.

Drost (Gerrit) van 's-Gravenhage, kwam op Java 1786, was bij de verovering President van Boedelm. en Eerste Vendumeester; was in 1813 Notaris, ,hetwelk voor het tegenswoordige een sober bestaan opleverd", schrijft hij. Verzamelde niettemin boeken, curiosa, etsen, penningen enz. Wordt 1835 gepensionneerd als lid der Weeskamer. Overlijdt 15 Mei 1836 oud 71 jaar. De weduwe heette Charlotte Josepha von den Busch. Zij overleed 29 Dec. 1844.

Dubois (J. A.) van Middelburg; vergelijk Priangan IV p. 710 
noot 2; opgeleid aan de Marineschool te Samar., bij de verovering Kapitein der genie. Werd 9 Nov. 1811 aangesteld tot Surveyor and in charge of charts and plans op 150 \$. Proc. 28 Nov. 1811 wordt hij benoemd in eene commissie voor de bewaring van plans en kaarten; Proc. 15 Aug. 1812 blijkt, dat hij een algemeen register had te maken van de te Bat. bijeengebrachte stukken van dien aard; echter blijkt, dat hij in 1812 steeds te Buitenzorg werkzaam was (waaruit misschien volgt, dat die kaarten daarheen waren overgebracht); ook dat hij zelf meewerkte aan het verbeteren van kaarten; tot zijne beschikking stond een teekenaar op 150 \$ (dus Brandel). Den 7 April 1813 schrijft de Regeer. aan den Resid. van Bantam, dat D. in verband met den afstand van landen aldaar, derwaarts gaat als Assistant surveyor. Hij bleef verder gedurende het heele Eng. bestuur met Flikkenschild werkzaam aan de opneming van die residentie. Werd er later Assistent Resident. Maakte zich vooral in de Lampongs verdienstelijk (Van de Graaff I, 34; Francis, Herinneringen I, 106; $112 ; 136$ e.v.).

Dupuy (James), geb. te London 20 April 1792, kwam op Java 24 Maart 1812, dus nog geen 20 jaar oud. Zijn vader was nog in 1818 in dienst der Eng. O. I. C. (Bijdr. 1898 p. 249); hij was verder een oomzegger van Pierre Philippe Dupuy van London, die 3 Dec. 1786 te Bat. trouwde met Alida Olpherdina Janke, vermoord werd als Commandeur van Bantam en wiens dochter en eenige erfgename was Maria Wilhelmina D., welke in 1813 uit Engeland, waar zij bij hare Eng. familie had gewoond, overkwam en later trouwde met Van Heerdt, terwijl onze James, die dus haar neef was, den $31 \mathrm{Mei}$ 1815 trouwde met Elis. Joh. van Groll. Uit de Gaz. van 13 Juni 1812, waar hij ten gerieve der Ned. ingezetenen een Eng. vers vertaalt niet in het Ned. maar in het Fransch, blijkt wel, dat hij heel weinig Ned. verstond; in 1815 vertaalt hij echter Doornik's brieven in het Engelsch.

Hij komt reeds Proc. 10 Oct. 1812 voor als Assistant Secretary and Registrar op 300 \$. Proc. 12 Maart 1813 wordt hij van First Assistant bevorderd tot Deputy Secretary op 375 \$. Bij kennisgeving van 28 Mei 1813 tevens benoemd tot Commissioner of the Court of Requests te Bat.; dit laatste bracht geen salaris mee; evenmin de betrekking van lid van het Commercial Committee, waarmee hij tegelijk werd vereerd, maar als Deputy Secretary was zijn salaris thans 500 \$, misschien omdat hem Gaz. 23 April 1814 was opgedragen 
to officiate as Secretary to Govt., namelijk gedurende de reis van Assey naar Bengalen, die 23 Sept. terugkwam. Volgens Addison (p. 378) werden Assey's werkzaamheden tusschen hen verdeeld en bleef Dupuy, die op beschermenden toon a pleasant young man wordt genoemd (ze waren beiden even oud !) belast met what he at present chiefly manages - the Batavian business. Proc. 1 Nov. 1813 was hij bovendien op 100 \$ benoemd tot Superintendent der Pers en der Gazette; den 29 Oct. 1814 schrijft de Regeer. aan Bauer, dat D. has resigned the office of Editor of the Gov. Gaz. Hij werd als Superintendent of the Gov. Press opgevolgd door Hanson. Voor dergelijken arbeid had hij anders veel lust; reeds in de Gaz. van 9 Mei 1812 komen verzen van hem voor op zijn vertrek uit Engeland; zoo vindt men in het nummer van 23 Jan. 1813 een gedicht van hem op de overwinning bij Salamanca, maar nu en dan gaf hij in zijne Engelsche rijmelarijen (veel meer is het niet), welke hij, in strijd met de gewoonte, placht te teekenen met zijne voorletters, wat veel toe aan dartele neigingen, die verontwaardigde protesten van schaamrcode Britishers uitlokten, welke hem ten slotte deden verstommen. Hij bleef tot het eind Deputy Secretary (werd Proc. 3 Nov. 1815 ook lid van het Revenue Committee) en ging daarna over in Ned. dienst als Secretaris van den Raad van Financiën. Elout vond hem ,braaf en niet onbekwaam” (Van Deventer p. 245). Heeft allerlei hooge betrekkingen bekleed en is eerst 27 Mei 1881 overleden. Zijne vrouw was, als gezegd, Elisab. Joh. van Groll, geb. te Zwolle 1789, overl. te Batavia 3 Oct. 1861. Uit dit huwelijk waren kinderen.

Zijn oudste $z o o n$ was Pieter Breton v. Groll (Testam. Drost 20 Juni 1817 no. 10384). Zijn broer heette Pieter Philip du Puy. Eene Petronella Philippina Du Puy, vrouw van P. A. Oelrichs, overlijdt te Bat. 30 Juni 1835.

Eales (J.), Lieut. Col. van Comps. troepen, wordt, pas van verlof naar Europa teruggekomen en van Calcutta naar Java gezeild (Gaz. 29 Febr. 1812), bij General Orders van 22 April 1812 belast met the temporary command of the Batavian Division of the army. Den 28 Mei 1812 benoemde Raffles hem vanuit Tegal tot provisional Member of Council until further orders; volgens de Gaz. van 13 Juni nam E. zitting op den 12en, maar volgens de Proc. alleen op 3 Juli en 22 Juli 1812; bij de eerstvolgende vergadering, den 15 Aug., was Gillespie terug, die na 1 Febr. niet verschenen was. De Gaz. 15 Aug. 1812 bevat zijne bevordering tot Colonel. Wordt bij 
General Orders van 22 Oct. 1812 benoemd tot Resid. en Commandant in Palembang en Banka, waarheen hij 1 Nov. vertrekt; hij genoot als zoodanig $500 \$$. Hij werd echter op Banka ziek en moest naar Java terug (Widow p. 606; 609) en werd bij Gaz. 27 Maart 1813 opnieuw belast met the command of the Western Division. Bij Gen. Orders van 1 Mei 1813 aangewezen to command the Samarang Division of the army (ter vervanging van Watson), en Proc. 24 Aug. 1813 bovendien tot Resident aldaar. Den 1 Sept. nam hij de residentie over van Hardy, maar hij vertoefde zeer zelden te Samar., zoodat veeltijds Hardy als Deputy Res. het werk deed. Proc. 17 Sept. 1813 zegt Raffles, dat hij E. heeft belast met den aanslag der landrente in Samarang (met Kendal en Demak) en Japara (met Joana, Pati en Koedoes); Pemberton was echter reeds 2 Sept. aangewezen om hem te helpen. Als Resid. trok hij $600 \$$ plus $2 \%$ der netto opbrengst van de landrente; als officier bovendien 1948 Sonat Rupees p.m. Hij was echter voortdurend ziek, zoodat 8 Oct. 1813 Macquoid hem wordt toegevoegd voor den aanslag van Japara. Den 6 Nov. 1813 wordt goedgevonden, ook Luitenant Eckford aan hem toe te voegen; 23 Jan. 1814 wordt hem een verlof van 2 maanden verleend, met bepaling dat Crawfurd hem zal vervangen; het Revenue Dept. wordt aan den Resident onttrokken en onder Cotes geplaatst. Crawfurd bleef echter slechts tot 12 April; den 18 April geeft E. zijne residentie over aan den nieuwen plaatsvervanger Garnham. Bij schrijven van 10 Mei 1814 bericht de Regeer. aan E. (die nog steeds Resid. van Samarang heette), dat hij tot plaatsvervanger van Crawfurd als Resid. te Djokja is benoemd; hij aanvaardt die betrekking $29 \mathrm{Mei}$, geeft haar 5 Juli 1814 weder over aan Crawfurd, neemt 15 Juli 1814 Samarang weer over van Garnham. Bij schrijven van 1 Aug. 1814 bericht de Regeer. hem, dat hij zal omwisselen met Adams te Soerabaja, als Resid. en Commandant; den 12 Aug. verzoekt hij echter wegens ziekte ontheffing dier benoeming, wat 26 Aug. wordt toegestaan. Den 1 Sept. 1814 nam Adams de resid. Samar. over, die er ook Commandant werd. Wat er vervolgens met $\mathrm{E}$. gebeurde, is mij niet bekend; misschien werd zijn verlof verlengd; hij maakte echter promotie tot Major-General, kwam $11 \mathrm{Mei}$ 1815 van Soerabaja te Bat. en vertrok 1 Juni met Adams naar Europa. Over zijne geschiktheid voor eene burgerlijke betrekking is het niet mogelijk te oordeelen, daar hij eigenlijk nooit daarin optrad. 
Eckford $(J$.$) , Lieutenant 6th Batt. Bengal Volunteers, wordt Proc.$ 21 Oct. 1811 benoemd tot waarnemend Secretaris van den Lieut. Gov. op 375 \$; Proc. 14 Febr. 1812 tot Assistant Secretary Public Dept. op 300 \$; den 16 Juli 1812 tot Assistant to the Resident at the Court of Souracarta op $375 \$$; den 11 Nov. 1812 tot Secretary to the Civil Commissioner (d.i. Hope) and Assistant to the Commissioner for settling the transferred districts, op $200 \$$ for each appointment. Proc. 22 Jan. 1813 wordt hij benoemd tot Resident van Grobogan met Poerbadadi en Wirosari op 250 \$ p.m. en $2 \%$ der revenue collections; echter blijkt hij tevens Secretaris van Hope te zijn gebleven, ook nadat hij als zoodanig eenigen tijd wegens ziekte door Loudon en Greene was vervangen. Als Resident heet hij nu eens Resident van Grobogan, dan weer Resident van Poerbodadi. Den 6 Nov. 1813 keurt de Regeer. goed, dat hij wegens ziekte van Eales assisteert bij den aanslag van Samarang; voor dien arbeid trok hij 150 \$ p.m. Den 24 Jan. 1814 schrijft de Regeer. hem, dat hij worlt benoemd tot Collector of the late residencies of Purpadados and Djepan op 1.200 Java Roep.; ,this arrangement is not at present to interfere with the settlement of Lieutenant Pemberton's late residency", waarmee Pemberton zal doorgaan on the tiang halit system. Hij kwam 22 April 1814 te Padangan en aanvaardde er het bestuur over Grobogan en Djipan als Resid., opvolger van Pemberton; hij bleef echter tevens zich Resident van Poerbodadi noemen en had twee residentiehuizen, een te Grobogan en een te Padangan. Bij Proc. 10 Aug. 1815 werd de residentie Grobogan en Djipan opgeheven, doch E. bleef voorloopig belast met het bestuur daarvan; tevens echter werd hij benoemd tot Collector of Revenue in Soerabaja, als opvolger alweer van Pemberton; E. beschouwde dit als eene promotie en gaf 3 Sept. 1815 Grobogan en Djipan over aan Van Teijlingen, om 8 Sept. het werk van Pemberton over te nemen. Had, volgens Crawfurd, Pemberton den aanslag in Soerabaja veel te hoog opgedreven, dezelfde Resident prees E.'s tenderness for the native character. Doch reeds 13 Dec. 1815 moest hij zijn collectorship overgeven aan Cotes en naar Bat. vertrekken om zich weer bij den troep te voegen. Den 20 April 1816 werd hij belast met het commando over het Amboynese Corps. Hij was een der onderteekenaars van het afscheidsadres van Raffles' persoonlijke yrienden, Gaz. 6 April 1816. Een welmeenend jongman.

Ekeboom (P.), een Ceilonsche mixties, onder Daendels Eerste 
luitenant der rijdende artillerie, was van af Juni 1812 Assistant to the Resident te Cheribon op $150 \$$. Waarschijnlijk is dit op te vatten als een schrijversbaantje; eerst 17 Sept. 1813 schrijft de Regeer. aan den Accountant, dat hij is benoemd tot Assistant aldaar; we vinden deze benoeming in Gaz. 18 Sept. en andermaal in Gaz. 18 Dec. 1813, omdat hij den 9 Dec. tot opvolger van den Assistant Higgins was benoemd, die 21 Dec. naar Bengalen vertrok. Om ruimte voor dezen te maken, was $\mathrm{E}$. intusschen in Tegal geplaatst. Gaz. 22 Oct. 1814 bevat opnieuw zijne benoeming tot Ass. to the Res. of Tagal, waar hij 1 Nov. aankwam. Hij overleed te Cheribon 29 Maart 1815.

Engelhard (P.), zie Priangan I, p. 88 e.v. Was bij de verovering Minister te Djokja. Vraagt 28 Sept. 1811 ontslag als zoodanig wegens ziekte; hij was overigens ,,als een Hollander van de oude constitutie” den Engelschen genegen. Dit ontslag werd aangenomen bij een schrijven van de Regeer. van 25 Oct. 1811, overhandigd door zijn opvolger Crawfurd, die 15 Nov. als Resident optreedt. Zijn weduwe Cath. Joh. van Riemsdijk hertrouwde 11 Oct. 1812 met P. van Heemstede Cappelhoff.

Erentreich (C.F.) wordt Proc. 15 Aug. 1812 benoemd tot Scriba te Grissee. Teekent zich echter ook wel Assistent Resident. Zijn voorganger G. W. A. de Roock had 50 \$ traktement. De Halfyearly Directory 1815 noemt E. als Assistant in Grissee; het boekje voor 1816 noemt hem Scriba.

Ermatinger (J. R.), een Zwitser, kwam in Juni 1789 op Java; was bij de verovering Koffieopziener in Soemedang; wordt 2 April 1812 bevestigd als Opz. 1e klas aldaar op 100 \$. Overleed er in 1836 of '37 op hoogen ouderdom.

Everest (George), geboren 1790, ging 1806 als cadet naar Indië. Diende op Java als Luitenant der Bengal Infantry tijdens Raffles, die hem den 13 Juli 1815 eene instructie gaf voor de reeds door Colebrooke begonnen opname der Solorivier. Heeft later naam gemaakt als Surveyor General of India. Naar hem is genoemd de Mount Everest, de hoogste berg der aarde, zoodat hij nog zal worden vermeld, als de namen van Raffles en Minto reeds zullen zijn vergeten. 
Evertse (E.) wordt scriba te Tegal 15 Dec. 1811; komt als zoodanig voor in 1812 en 1813.

Farquharson, Lieutenant, wordt Proc. 12 Sept. 1815 benoemd tot Assistant Res. te Cheribon; komt aldaar op dienzelfden dag in die qualiteit aan, doch wordt reeds Proc. 27 Oct. 1815 teruggeroepen om naar Bombay te gaan.

Fendall (J.), geb. 1762, door Moira benoemd tot Lt. Gov. van Java en Onderhoorigheden 8 Dec. 1815 (Van der Kemp, Teruggave p. 13); komt op de reede van Bat. 11 Maart 1816 met zijne vrouw en drie dochters; landt den 12en en wordt direct geinstalleerd. Hield een beetje opruiming onder Raffles' personeel. De Gaz. 6 Juli 1816 stelt dan ook bij den versregel: And latent storms on every gale are borne, de aanteekening : exampled in the Ex-Residents, Ex-AssistantResidents, Ex-Collectors etc. Zijne bemoeïngen betroffen (blijkens bewaarde kantteekeningen) speciaal zaken van rechtspraak; ook bij andere kwesties openbaart hij nu en dan a pettifogging spirit; bijv. Proc. 27 Mei 1816, waar hij naar aanleiding van de verhuring van een perceel djatibosch heelemaal in het onbevolkte Banjoewangi, eerst verlangt te weten hoeveel en wat soort van boomen op dat perceel staan! Overigens een veel nauwgezetter en meer rechtschapen man dan Raffles, eenvoudig en vrij van humbug en cant, maar zéér alledaagsch van geest. Bleef op Java tot 29 Juni 1817 (Bat. Cour. van 5 Juli no. 17); later Member of Council te Calcutta.

Flikkenschild (J.) van Samarang, doet 1806 eindexamen der Marineschool aldaar als cadet der artillerie en wordt geplaatst „,bij de meetcommissie"; is bij de verovering Eerste luitenant. Is Jan. 1812 teekenaar 1e klas onder Cornelius; 10 Maart 1812 noemt deze laatste hem en Karseboom „,two of my best draftsmen”; op last van Raffles waren zij naar Buitenz. gezonden, waar zij in Juni 1812 bezig waren met ,het afteekenen van de onlangs door mij verbeterde kaart van het eijland Java", en die van Celebes en Banka, schrijft Dubois. Daarna is F. als assistent van Dubois werkzaam in Bantam, alwaar Francis (Herinneringen p. 100) hem in 1815 vond; in 1850 woonde hij te Solo.

Flint (William), Captain of the Royal Navy, trouwde in 1811 te Malakka met Raffles' derde en meest geliefde zuster Mary Anne, 
geb. 1789, de eenige der zusters, die op schoonheid aanspraak kon maken; zij was met haar broer uitgekomen en in 1805 met een Q. D. Thompson gehuwd, die in 1809 was overleden. Uit Flint's huwelijk werd 18 Jan. 1813 bij de Luthersche gemeente te Bat. gedoopt een zoon Stamford Charles Raffles, die al den 16 Sept. 1812 was geboren. De eenige thans nog levende afstammelingen van Raffles' ouders zijn gesproten uit Flint en Mary Anne, terwijl zij, die den naam Raffles dragen, uit een broèr van diens vader zijn.

Bij beschikking van Minto 9 Aug. 1811 werd F. aangewezen to take charge of the public property captured at Batavia, eene beschikking, die bij Admiraal R. Stopford zulk eene woede wekte, dat hij 6 Sept. den Captain met eene crimineele vervolging bedreigde, als deze het zou wagen zich te bemoeien met de zaken der door leger en vloot van $\mathrm{Zijne}$ Majesteit benoemde Prijsagenten. De benoeming van F., die een merkwaardig bewijs van Raffles' invloed bij Minto is, had, blijkens Proc. 10 Aug. 1815, ten doel om dezen zekere extra procenten van den buit te bezorgen; het voorwendsel was echter dat, daar ook troepen en schepen der Compagnie aan de verovering hadden deelgenomen, er diende gezorgd, dat een deel daarvoor werd afgezonderd; hun recht hierop werd echter door de Prijsagenten ontkend en F.'s benoeming genegeerd, oók omdat deze niet van den G.-G. had moeten uitgaan maar van de belanghebbenden. Toen Minto nog te Bat. was, drongen de Prijsagenten er bij Flint op aan, dat deze om eene bepaalde omschrijving van zijne bevoegdheden en eene officieele benoeming zou verzoeken. Maar daar kwam niet van; Raffles vond het denkelijk meer geraden om alles vaag en onbestemd te laten, meenende te zijner tijd de Prijsagenten wel te zullen kunnen bepraten om zijn zwager te erkennen, wat geheel falikant uitkwam. Men kan begrijpen, welke onaangename discussies het een en ander na Minto's vertrek veroorzaakte, en hoe Raffles' prestige bij de militairen daardoor werd geschaad.

Intusschen had F. den 3 Nov. 1811 zijne nieuw verkregen betrekking van Inspecteur Generaal der Houtbosschen en van den weg, beide beoosten Soemedang, aanvaard (de datum der benoeming is onzeker), respectievelijk op 500 en $200 \$$; onder de eerste was die van Timberstorekeeper begrepen. Proc. 28 Maart 1812 werd hij bovendien Superintendent of Marine Accounts op 200 \$, een expres voor hem gecreëerd baantje, dat 1 Oct. 1812 werd ingetrokken, doch dour hem bekleed bleef, totdat zijn salaris als Timberstorekeeper den 19 Febr. 1813 kon worden verhoogd tot 600 \$; Superin- 
tendent van den weg bleef hij, totdat ook dit baantje bij zijn vertrek naar Europa 1 Nov. 1813 werd afgeschaft. Proc. 10 October 1812 wordt hij ook vermeld als havenmeester te Rembang en Superintendent der werf op $\$ 500$; zijn totaal salaris (ongerekend dat als officier) beliep toen $1.100 \$$ p. m. Of Flint's bemoeienis met de werf te Rembang (zie de personalia van Foote) eene bron van ongeoorloofde inkomsten kan hebben uitgemaakt, blijkt niet. Hij benutte echter de gelegenheid, om Gouv. grond bij Serondol te koop te vragen, een perceel van 23 morgen, waarop hij alvast een huis had gezet en waarbinnen de desa Serondol lag; besloten werd toen (Proc. 24 Aug. 1813), hem geen koop maar huur toe te staan van een stuk buiten gezegde desa; later nogmaals (Proc. 19 Nov. 1813), dat die huur voor 25 jaar zou zijn; niettemin schrijft de Resid. van Samarang 10 Oct. 1815 , dat hij de $18^{3 / 5}$ morgen grond, door Flint aangevraagd, taxeert op 125 Sp. Dollars, waarop den 19 Oct. 1815 het marginaal besluit valt: The sale of the ground for this sum is authorised and the transfer may be made accordingly. In het bijvoegsel der Bat. Cour. van 2 Aug. 1817 vindt men eene advertentie, waarbij Flint dit perceel van 50 acres (dus ongeveer $1 / 3$ meer dan volgens de opgave van den Resident), genaamd Mount Olivia, met het huis daarop te koop presenteert, met de bijvoeging: The ground was purchased from Govt. and is held in perpetuity. De verkoop aan F. was dus een der maatregelen van Raffles met het oog op zijn eigen aftreden. Over dit land zie Tijdsch. voor Nijv. en Landb. XXII (1878) p. 571.

Den 1 Oct. 1813 kwam F. met zijne vrouw te Bat.; samen vertrokken zij den 21 Oct. naar Engeland met hun kind en Miss Raffles, wellicht Harriet. Deze reis geschiedde, blijkens Proc. 22 Oct. 1813 (waarbij hem verlof werd verleend) om zijne belangen als Prijsagent te verdedigen; hij kreeg vrije passage, zijn traktement hield echter op en met zijn baantje van Timberstorekeeper werd 1 Nov. Raffles' andere zwager Brown begunstigd. Eerst 31 Juli 1815 kwam F. (zonder zijne vrouw) terug, samen met Travers en John Scott; Proc. 10 Aug. 1815 wordt hij nu benoemd tot Superintendent of Teakforests en Resid. van Rembang. Den 1 Sept. bericht hij de residentie te hebben aanvaard. Elk dezer beide betrekkingen, die hij tot den terugkeer der Nederl. bleef bekleeden, gaf hem 1.200 Java Roep. p. m. ; verder had hij $5 \%$ der custom duties, maar dit beduidde weinig. Van Fendall kreeg F. nooit wat anders dan hatelijke opmerkingen te hooren. Begin Febr. 1817 verliet F. Java; in 1820 kwam 
hij er terug om te Samarang zaken met Deans en Scott af te doen; zijne vrouw was toen te Singapore en zij beiden evenzoo in 1822 . Raffles had aldaar in 1819 een perceel grond voor hem gereserveerd (Campbell I, 623; Widow p. 441; 461; 531). In 1824 was Flint havenmeester te Singapore (Nahuijs, Brieven over Bencoolen p. 241, die ook meedeelt, dat men daar destijds nog gratis grond in eigendom kon krijgen, wanneer men de opgezetenen uitkocht).

Foote (John) (of dit de „Engelsche kapitein Foote” is, vermeld in een besluit van Daendels 22 Aug. 1810, die namens Admiraal Drury te Bat. kwam, blijkt niet). De Regeer. zegt Proc. 22 April 1814, dat hij was employed a length of time in His Majesty's dockyards. Werd in Oct. 1811 benoemd tot Master Attendant te Rembang en Superintendent of shipbuilding, of wel Master Builder, zooals hij ook wel heet; den 17 Febr. 1812 nam hij ook de stores (denkelijk de Marine stores) te Rembang en Joana over (reeds in Proc. 1 Nov. 1811 wordt de gecombineerde betrekking van Master Attendant and Storekeeper at Rembang vermeld met het salaris van 500 \$); vervolgens kreeg hij ook het beheer der houtstapelplaatsen te Rembang, dat hij echter weldra aan Flint moest afstaan, die Proc. 26 Febr. 1813 bovendien tot zijn chef in zake de timmerwerf werd gemaakt. Foote was een bazig en brutaal heerschap en zijn werk bestond niet uit louter meesterstukken. Zijn salaris wordt verschillend opgegeven, 500 \$, 300 \$, 600 of 660 Java Roep. Den 16 Jan. 1814 schrijft de Regeer. aan den Resident van Rembang, dat zij de werf aan Foote wil verhuren, doch zóo dat het werkvolk onder hare eigene orders blijft; van toen af was de werf eene particuliere zaak en $\mathrm{F}$. bleef dus enkel Havenmeester, wat hij nog was bij de teruggave.

Forsstecn (W. H.), Lieuten. Col., komt 19 April 1816 uit Bengalen te Bat.; wordt Proc. 26 April benoemd tot Resid. van Tegal en bij Gen. Orders van denzelfden dag tot militair commandant over Tegal en Cheribon; neemt 11 Mei de residentie over van Ivatts en blijft zijne betrekking bekleeden tot de teruggave. Het heet dat hij er van gebruik maakte om goedkoop koffie op te koopen. Zie nog Van der Kemp, Herstel p. 254; N.-I. Bestuur p. 23.

Francis (E.) (nergens heb ik in het Eng. archief of de Gazette een spoor van dezen man ontdekt) landde op zijn 17e jaar als schipbreukeling aan de kust van Straat Soenda in Juni 1815 en werd 
reeds in Augustus door Resident Yule aan een baantje van 150 ropijen geholpen. Hij kwam buitengewoon goed van pas, want juist 1 Maart 1815 had de Resident geklaagd, dat zijn eenige Europeesche schrijver geen Engelsch verstond. Francis, die in 1798 dicht bij Cochin was geboren (Herinneringen, I, 76), verstond die taal wel, maar noch Maleisch noch Nederlandsch. Ging later in Nederl. dienst over en bracht het tot hooge betrekkingen, ook tot President der Javasche Bank.

Garnham (Robert C.), Captain 3d Batt. Bengal Volunteers, een der meest gebruikte helpers van Raffles, omtrent wien echter (zoo als dat met meer ambtenaren het geval is) uit de Proc. heel weinig blijkt.

Den 11 Oct. 1812 schrijft hij, dat hij sedert 23 Jan. op last van Gibbs het civiel en militair gezag over het gansche eiland Madoera heeft gevoerd; bovendien komt hij Proc. 10 Oct. 1812 voor als Resident van Samarang op 600 \$. Maar wat eerstgenoemden werkkring aangaat, de Regeer. antwoordt 21 Oct., dat hij oorspronkelijk alleen Commandant van Madoera was ,while he was considered to perform the civil duties of the drostship of Sumanap"; met deze beide werkzaamheden blijft hij nu belast. Naar Samarang was hij gegaan om den zieken Lawrence te vervangen; bij besluit van 4 Nov. 1812 werd hem dat gelast (nadat het reeds was geschied); den 18 Nov. geeft hij Soemenap weer tijdelijk over aan Dragheim en aanvaardt 23 Nov. 1812 de residentie Samar.; zijn opvolger op Madoera (in beide qualiteiten) werd Proc. 4 Nov. 1812 Clark. Den 5 Nov. 1812 werd hij president der Commissie voor den landverkoop in Samarang. Bij schrijven van 22 Juli 1813 wordt G. opgeroepen naar Batavia, in verband met eene politieke zending als Commissioner op 750 \$ p.m.; den 31 Juli geeft hij Sam. over aan Hardy, vertrekt 1 Aug. en arriveert 9 Aug. te Batavia. Hij verloor zijne betrekking als Res. van Samar., toen de Regeer. 24 Aug. 1813 Eales daartoe benoemde; tegelijk echter werd G. benoemd tot Resid. van Bezoeki en Probolinggo, waar Cotes voorloopig hem bleef vervangen. Van Batavia vertrekt G. 21 Aug. 1813 per H. M. Malacca naar Sambas ,and other principal ports in Borneo and the Celebes" in verband met de beteugeling van den zeeroof; misschien tot meerder aanzien droeg hij tevens den titel van Honorary Aide-de-camp of the Lieut. Gov. en had hij eene lijfwacht, maar de zending droeg een vreedzaam karakter. Den 23 Nov. 1813 vinden we hem terug te Samarang; 
vandaar kwam hij 4 Dec. 1813 te Bat. om verslag van zijne zending te doen; den 16 Jan. 1814 geeft de Regeer. hem verlof om naar zijne nieuwe residentie te vertrekken, doch eerst 4 Febr. vertrekt hij, nadat de Regeer. den 24 Jan. had bepaald, dat ,the authority of Captain G. as Resident of Basuki extends to the districts lately (d.i. tot dusver) comprising the residencies of Passuruwang and Bannuwangie", behalve in zake de landrente, waarvoor elk der drie districten een apart Collector kreeg. Den 14 Febr. 1814 neemt hij Bezoeki over van Roxburgh (die belast bleef met de Revenue), maar bij schrijven van 24 Febr. 1814 herstelt de Regeer. de afzonderlijke residenties Pasoeroean en Banjoewangi en onttrekt die aan G.'s gezag. Reeds 1 April werd hem gelast, om Samarang over te nemen van Crawfurd; hij geeft dus 12 April Bezoeki weer aan Roxburgh over en treedt 18 April als waarnemend Res. van Samar. op. Ook te Samarang bleef G. echter slechts tot 15 Juli, toen hij met Sir Samuel Hood op reis ging naar Bezoeki; den 30 Juli is hij met dezen hoogen gast te Batavia, en in de Gazette van 27 Aug. 1814 lezen we zijne benoeming tot Resident van Djokja, waaraan een salaris van 1.500 Java Roep. was verbonden; of hij als Honorary Aide-de-camp iets trok, waartoe hij bij een schrijven van 8 Aug. 1814 formeel werd benoemd, blijkt niet. Den 20 Sept. neemt hij Djokja over van Crawfurd. Hier bleef deze zwerveling bijna een jaar. Den 17 Juli 1815 schreef het Hoofdkwartier te Weltevreden, dat hij met zijn bataillon naar Bengalen moest vertrekken; den 31 Aug. geeft hij Djokja over aan zijn Assistant Taylor, komt 23 Sept. te Bat. en vertrekt 8 Oct. naar Bengalen. Den 15 Dec. 1815 echter geeft de Legercommandant aldaar hem verlof om naar Java, waar hij zoo goed voldaan heeft (men vraagt zich af, in welke qualiteit) terug te keeren; hij komt dan ook 13 Maart 1816 te Bat. terug, na reeds bij Proc. 1 Maart tot Resident van Samarang benoemd te zijn, een der laatste bestuursdaden van Raffles, die vermoedelijk zooveel tegenkanting vond, dat Garnham bij Gen. Orders van 22 Maart verlof erlangt om naar Europa te gaan; hij vertrekt 25 Maart met Raffles op de Ganges. Dat hij ongewone bekwaamheid bezat, is mij niet gebleken.

Geugten (A. F. van der) wordt in 1799 leerling der Marineschool, doet eindexamen in 1803, maar blijft bescheiden onder Cornelius; was bij de verovering Kapitein der genie; daarna weer teekenaar onder Cornelius. Den 4 Febr. 1812 schrijft hij aan dezen over kaarten, welke hij voor Robison heeft gecopieerd; omdat deze laatste hem 
niet betaalde, heeft hij de kaarten (welke Hope remarkably well finished noemt) aangehouden. Verder is er herhaaldelijk sprake van opnemingen door Van der G.; 26 Aug. 1812 zegt Cornelius, dat hij als Opziener 1e klas wordt gebruikt voor den kazernebouw te Salatiga and to survey the antiquities at Brambana. Voorts blijkt, dat hij van Juli tot Sept. 1814 op 200 Java Roep. p. m. werkzaam was onder Cornelius, dus (zie diens personalia) vermoedelijk bezig met het in beeld brengen van oudheden. De Directory voor 1816 noemt hem Private Assistant to Mr. Cornelius.

Gibbs (S.), Colonel, neemt deel eerst aan de verovering van Mauritius (Mill, History VII, 340), daarna aan de bestorming van Meester Cornelis (Conquest p. 19; 58; 64; 65); neemt 12 Sept. 1811 Samarang met landingstroepen zonder slag of stoot in (ib. p. 97) en verslaat daarna Prangwedono bij Serondol (ib. p. 98). In Gen. Orders van 29 Sept. 1811 wordt hij vermeld als in command to the Eastward. Minto benoemde hem 15 Oct. 1811 tot Deputy Civil Commissioner op 500 \$; tevens werd hij bij General Orders van 24 Oct. op 1.500 Sicca Roep. extra toelage benoemd tot Commandant te Soerabaja. Goldbach noemt hem in een brief van 17 Oct. 1811 ,,een allerfatsoendelijkst man, die het zig een genoegen maakt het algemeen nuttig te weezen"; ook Minto gewaagt met lof van zijn talents, discretion and temper. Voorloopig was aan Gibbs toegestaan, om Goldbach in functie te laten als Landdrost, tot hij zich wat in de zaken zou hebben ingewerkt (schrijven van Hope, 1 Nov. 1811); later klaagde Goldbach echter dat, of schoon Gibbs niet veel lust had aan eene burgerlijke betrekking, hij toch aan hèm niet veel overliet. Blijkbaar een flink man. Reeds 12 Maart 1812 echter verzocht Gibbs om wegens ziekte naar Europa te mogen terugkeeren; misschien had hij met Raffles ongenoegen gekregen, want dit schrijven kruiste zich met een brief der Regeer. van 13 Maart, waarin hem werd gelast naar Bat. te gaan en zijne betrekking over te geven aan Assey. Den 20 Maart gaf hij de kas over aan Hope en 10 April zijne betrekking aan Assey. Hij had gewoond op Simpang. Bij Gen. Orders van 19 Maart 1812 was hem toegestaan naar Europa terug te keeren en de Gazette van 21 Maart bevatte een fraai afscheidscompliment. Hij werd spoedig bevorderd tot Major-General en commandeerde in Aug. 1813 te Stralsund; nam daarna deel aan de bevrijding van Nederland; werd als Sir Samuel Gibbs in den Amerikaanschen oorlog zwaar gewond bij de bestorming van New Orleans en over- 
leed 9 Jan. 1815 (Gaz. 26 Febr., 4 Juni, 30 Oct. 1814; 24 Juni, 1 en 12 Aug. 1815).

Gillespie (Robert Rollo; de naam moet worden uitgesproken op zijn Hollandsch, maar met den klemtoon in het midden), Colonel, daarna Major-General. Anonieme biographie (door Thorn) getiteld: A memoir of Major-General Sir R. R. Gillespie, K(night) C(ommander) $\mathrm{B}(\mathrm{ath})$, London 1816; voorin eene gravure naar een portret van G. 1814 door Chinnery. Uittreksel van dit werk in Asiatic Journal II, 145 e.v.

Geboren 21 Jan. 1766 uit eene deftige Schotsch-Iersche familie in Ulster, als eenige zoon; in zijne jeugd zeer verwend ; wordt 1783 tegen den zin zijner ouders Cornet bij de cavalerie, leidt een losbandig leven en ontwikkelt zich tot een der typische zwaar drinkende, duelleerende, rossende en rijdende maar tevens verwijfd doende dandies uit den tijd van den Prince-Regent, the First Gentleman of Europa, ,our abstemious Monarch”, zooals Raffles hem later schamper betitelde, toen hij order gaf om een vat Bataviasche arak voor Z. M. in te slaan. G. trouwt op zijn 20e jaar in het geheim met eene jonge dame van goede familie, van welke wij in zijn later leven niets meer vernemen; daarentegen laat zijn biograaf wel iets doorschemeren omtrent zijne maitressen. Een paar maanden na dit huwelijk heeft hij een duel aan een zakdoek (waarvan elk der strijders een tip vasthoudt); hij schiet zijn tegenpartij dood, neemt de vlucht; er wordt een prijs gesteld op zijne arrestatie; hij geeft zich gevangen en wordt vrijgesproken. Alles echt Iersch; nog Ierscher is, dat hij eenige jaren later in den schouwburg te Cork ruzie krijgt, stompen uitdeelt, en weer moet vluchten, ditmaal verkleed als vrouw! Hij strijdt op San Domingo en toont zich een geweldig vechter; bij zekere gelegenheid wordt hij in zijn huis overvallen door acht mannen, waarvan hij, ofschoon klein van stuk, er zes neerlegt. In 1805 reist hij over land naar Indië, heeft allerlei avonturen en krijgt te Bagdad van Ali Pascha een Arabisch paard ,which became well known afterwards in India by the name of the donor". In 1806 toont hij zijn beleid en heldenmoed bij het dempen van een zeer gevaarlijk Sepoy-oproer te Vellore. Men kan begrijpen dat zulk een man met zulk een verleden, een jager die voor de lol te paard met de lans een tijger kon aanvallen en dooden, een dragonder met al den lust van een dragonder voor wijntje en Trijntje, die een drinkgelag kon presideeren als bij de herdenking van de verovering van Meester 
Cornelis, waar his toasts were as rapid as his movements in the field, daarenboven van deftige familie en fijne vormen, neerzag op het obscure en 15 jaar jongere schrijvertje, dat door de gunst van Minto plotseling boven hem was geplaatst, een mannetje dat zich beroemde (horribile dictu) nooit een wedren te hebben bijgewoond of een vuurwapen afgeschoten, dat nooit de kaarten aanraakte en nooit te veel dronk, dat al maar aan den lessenaar of over een boek zat, dat eene wonderbare voorliefde toonde voor den omgang met niggers, maar tegelijk een hinderlijk talent om uit eens anders zwakheden munt te slaan, zich steeds gedekt te houden en de mooie rol te spelen, vrienden te winnen en aan zich te verbinden; een mannetje, dat nooit uit zijn humeur raakte en hem altijd en eeuwig te glad was. En men kan nagaan, hoe het in den heetbloedigen dragonder kookte, wanneer Raffles hem al glimlachend den voet dwars zette, of hem van uit zijne officieele hoogte complimenteerde met zijn betoond beleid en dapperheid, of als hij vernam, hoe die pennelikker en zijn patroon te Calcutta samen smoesden over zijne buitensporigheden (Widow p. 201). Waarbij nog op te merken valt, dat Minto geene reden had tot groote voorliefde voor militairen. Immers had er, speciaal te Madras, sedert jaren de heftigste tweespalt geheerscht tusschen civiel en militair gezag, die bijna tot een militair oproer had geleid.

Er was dus stof te over voor een twist. Al is het niet aannemelijk, dat vóór de verovering aan $G$. het stadhouderschap van Java was beloofd (Boulger p. 136), toch moest het hem prikkelen, te zien dat een Raffles, van wiens werkzaamheid nooit iets naar buiten was gebleken, de voorkeur kreeg boven hèm, die de voorhoede bij de landing had gecommandeerd, en den stormaanval op Meester Cornelis had geleid zoowel als de vervolging van den geslagen vijand (Thorn p. 17; 32; 55; 61). Den 3 Sept. 1811 (Minto in India p. 296) berichtte Minto aan het Secret Committee te London zijn voornemen om G. te benoemen tot Legercommandant op Java. Al vóór Minto's vertrek van Java was voor hem een zetel in Rade bestemd. Bij eene afzonderlijke instructie had Minto getracht de verhouding tusschen Raffles en hem vast te stellen; tusschen de regels van dat document dóór leest men, dat Minto veel minder op G.'s zelfbeheersching vertrouwde dan op die van Raffles. Bij proclamatie van 22 Oct. werd hij benoemd tot eerste Lid van den Raad met rang direct na den Lieut. Governor. In zijn rapport van 6 Dec. 1811 over zijne verrichtingen op) Java zegt Minto, dat hij G. tot tweeden persoon in Rade 
benoemde om Raffles te sterken, om zijne achting te bewijzen voor het leger en om aan G. meer inkomsten te verzekeren, (dus nict om G.'s groote gaven). G. echter toonde al dadelijk zijn kwaad humeur, door weg te blijven van de plechtige installatie der Regeer. op 21 Oct. 1811. In de vergadering van 1 Nov. 1811 legt hij den eed af, neemt zitting als First Member of Council en opent onmiddellijk de vijandelijkheden door eene nota in te dienen regarding the military arrangements and establishments in Java (een punt van groot verschil tusschen hem en den Lieut. Gov., zie Thorn's Memoir p. 200), welke nota in het Secret Dept. wordt gedeponeerd; eenige andere voorstellen van hem over militaire aangelegenheden worden door Raffles terstond òf verworpen òf opgeschort, iets wat later in Thorn's Memoir p. 192, 193 met bitterheid werd herdacht. In de vergadering van 16 Nov. 1811 casseert Raffles de reeds geschiede benoeming van zekeren stafofficier. Gillespie had dus nu kunnen weten wie de sterkste was. Bij Proc. 28 Nov. 1811 werd besloten, het oude en nogal vervallen huis Weltevreden voor G.'s woning in te richten; bij proclamatie van denzelfden dag werd hij aangewezen als VicePresident in Council gedurende de afwezigheid van Raffles, die dienzelfden dag op reis ging. Nauwelijks is deze vertrokken, of Gillespie drijft in de vergadering allerlei maatregelen door die gansch niet in den geest van den Lieut. Gov. konden zijn, speciaal de oprichting der Military Bazar in het kampement te Weltevreden. Zijn salaris als Raadslid beliep 750 \$, naar verhouding van andere traktementen zeker een matig bedrag. Wat echter Boulger beweert (p. 219), dat G. de vergaderingen van den Raad eerst geregeld bijwoonde na his disputes with R. which marked the year 1813, is niet geheel juist. De twist dateerde al, zooals wij zagen, van 1811; in Febr. en Maart 1812 bleef hij vijfmaal weg, doch ging reeds vóór 24 Maart op expeditie naar Palembang, waarbij hij wederom buitengewone doortastendheid en moed aan den dag legde (Thorn p. 139 e.v.). Van hier kwam hij te Bat. terug 31 Mei, doch vertrok reeds 5 Juni op expeditie tegen Djokja, waarbij hij in den linkerarm werd gewond (Memoir p. 128); hij ging daarna ter herstel in begin Augustus naar Tjipanas (Gaz. 1 Aug. 1812), kwam 9 Aug. te Weltevreden, woonde 15 Aug. eene raadsvergadering bij, doch bleef vervolgens in de bovenlanden; den 19 Oct. was hij weer present, maar van de eerstvolgende vergadering, die den 4 Nov. in overleg met hem te Buitenz. plaats had, bleef hij weer weg, welke houding hij volhield tot 23 Dec. Hij vertoefde destijds te Tjipanas, waar hij het warme bad gebruikte. In 1813 
kwam hij zeer ongeregeld ter vergadering, de laatste maal op 13 Aug. Den 24 Aug. 1813 werd hij wegens afwezigheid van R. tot Vice-President in Council benoemd. In de stad had hij behalve het huis Weltevreden eene woning op Rijswijk, een paar huizen van Raffles af (zie onder Robison); in de bovenlanden kon hij over het gehuurde landhuis Tjimanggis beschikken, dat bij het kampement aldaar behoorde; bovendien had hij zelf Tency's huis op Tjiloewar met de daarbij behoorende slaven gehuurd (Thorn p. 273); ook kocht hij drie slavinnen van denzelfde (iets zeer ongewoons voor een Engelschman). De twist met Raffles kreeg nieuw voedsel (Boulger p. 219), toen G. na de verovering van Djokja eigenmachtig over een deel van den buit beschikte, hetgeen $R$. zeer kwalijk nam, waarop G. excuses aanbood. De in Aug. 1812 tegen het advies van den Legercommandant doorgedreven vermindering der troepen (Boulger p. 220) was de oorzaak, dat deze de schuld van het Probolinggo-oproer op Raffles schoof (Thorn's Memoir p. 200); bovendien was hij verontwaardigd over de wijze van betaling der Sepoys (Boulger p. 222). Verder keurde hij de expeditie tegen Sambas (Oct. 1812) af en was hij zeer pessimistisch wat R.'s landrenteplannen betrof. Raffles daarentegen beweerde, dat G. te Tjipanas de bevolking had gekneveld en te Samarang zoowel als op de expeditie naar Palembang en elders allerlei ongerechtigheden had uitgehaald met weesen andere meisjes (Boulger p. 223; 237). Onwaarschijnlijk is dit laatste niet; doch Raffles kon natuurlijk de menschen te Tjipanas laten verklaren wat hij verkoos, en dat $\mathrm{G}$. een meisje voor zich had laten halen uit het weeshuis te Samarang, werd door de moeder van dat gesticht vierkant tegengesproken, hetgeen Raffles niet belette om die vuile beschuldiging in zijn gedrukt verweerschrift op te nemen, evenals eene aantijging, dat G. met soldaten een meisje uit een huis te Bat. had laten halen en dat hij volgens Robison in Palembang allerlei schandaligs had uitgehaald. Hoe het zij, Gillespie werd het harrewarren moede. Reeds 13 Febr. 1813 richtte hij een brief tot den Legercommandant Sir George Nugent in Bengalen met klachten over den landverkoop. Ook vroeg hij reeds omstreeks dien tijd zijn ontslag en kreeg dat (Boulger p. 226; Thorn's Memoir p. 201); uit Proc. 15 Oct. 1813 blijkt, dat hij vergunning vroeg om onmiddellijk naar Bengalen terug te keeren, dat deze werd verleend en hij den 10 Oct. (de Gaz. zegt: den 11en) scheep ging. Uit de advertentie zijner vendutie (Gaz. 18 Sept. 1813) zien wij, dat hij behalve eenige kostbare Arabische paarden ook ongeveer 100 dozijn flesschen wijn 
ter overname aanbood. Zijn vriend Thorn zegt dan ook (Memoir p. 203), dat hij eigenlijk niets bezat dan zijn traktement en zijne prijsgelden (die na de verovering van Java, Palemb. en Djokja een schoon bedrag zullen hebben uitgemaakt), en dat hij van heel ander hout was gesneden dan sommige kameraden, die al maar op voordeel uit waren; zelfs was hij door te goed vertrouwen in ongelegenheid geraakt (ibid. p. 246); had hij Raffles naar de oogen willen zien, dan had hij zijne beurs kunnen maken (ib. p. 252). Karakteristiek is ook, dat de pachter van de vischmarkt in $1814 \operatorname{nog} 7$ à $800 \mathrm{Sp}$. Dollars van G. te vorderen had ,for the supply of fish”. 's Mans verdere beren zullen wel naar verhouding zijn geweest van deze reusachtige vischrekening. Volgens Raffles had er vóór G.'s vertrek eene verzoening plaats. Den 18 Juli 1813 kwam H. M. Hussar, Captain the Honorable Elliot (Minto's zoon) te Bat. Deze bewerkte eene verzoening; voortaan had G., zegt Raffles, niets dan goede woorden; zelfs in zijn laatsten brief zei hij nog, dat hunne onmin het werk van anderen was geweest, doch reeds te Penang begon hij te spreken over de aanklacht, die hij in Bengalen zou indienen. Ook N. Engelhard schrijft in 1815, dat G. bij een brief uit Penang aan R. ,naadere betuiging van vriendschap gedaan" had, zoodat men zich verbaasde over ,het gedrag van Gillespy teegens de Gouverneur bij aankomst in Bengalen gehouden”. Daarentegen verdient opmerking, dat G. bij zijn vertrek van Java geen woord van dank of lof, waarmee de Regeer. anders gul genoeg placht te zijn, voor zijne schitterende verrichtingen kreeg, althans niet in de courant; deze nam geene notitie van zijn vertrek behalve eene vermelding van twee, drie regels, en het is dus zeer de vraag, of Raffles bij zijn heengaan tegenwoordig was. Wel werden er later (in de Gaz. van 7 Mei 1814) eenige verzen op „Rollo” opgenomen, die ,to his best friend proves a treacherous foe". G.'s gewezen secretaris Colebrooke schrijft in 1816, dat deze, toen hij naar Bengalen terugkeerde, verwachtte to return to Java the following year, dus als Minto was vervangen; zijn vriend Shrapnell kreeg de zorg voor G.'s infant child, dat eerst in het najaar van 1816 werd verzonden. De zending van dezen Colebrooke met R.'s vertrouweling Methven naar Bengalen, eene maand na G.'s vertrek, zal wellicht ook de strekking hebben gehad, om eene actie van dezen tegen te werken; in verband daarmee is het eigenaardig, dat de Major-General de reis samen deed met de vrouw van zijn medestander Blagrave. Ook is opmerkelijk, dat G. zelf in zijne carrière jaren lang had te kampen gehad met de gevolgen eener aanklacht, door 
een ondergeschikt officier tegen hem ingebracht (Thorn's Memoir p. 51 e.v.), en vermoedelijk een strijd tegen zijn beter ik heeft gestreden, aleer hij allerlei onbewijsbare aantijgingen tegen Raffles richtte. Onze aandacht wordt dan ook getrokken door het absolute stilzwijgen van zijn biograaf Thorn betreffende die aanklacht, waarmee zijn held blijkbaar weinig eer had ingeoogst onder zijne kameraden, hoe breedvoerig ook de aanleiding tot zijne ontevredenheid met den gang van zaken op Java wordt besproken. Wij laten de punten van aanklacht (over welke zie Levyssohn Norman p. 301 e.v., die geput heeft uit den bundel gedrukte stukken aangaande die zaak, waaruit in Nederland een extract is gedrukt) hier terzijde en noteeren nog enkel, dat G. te Calcutta landde op denzelfden dag dat Minto vandaar naar Engeland scheep ging; dat hij onmiddellijk mondeling klaagde over Raffles (vermoedelijk bij zijn eerste onderhoud met Moira) en reeds 17 Dec. 1813 op bekomen last van den Gov. Gen. stukken in verband met die aanklacht indiende. Hem was derhalve vóór zijne aankomst het hoofd geweldig warm gemaakt, misschien door zijne reisgenoote, Mrs. Blagrave. Raffles doet het in zijn verweerschrift steeds voorkomen alsof (geheel in strijd met G.'s karakter) de aanklacht van buitengewone arglist getuigde. Een onpartijdig waarnemer komt echter spoedig tot de slotsom, dat zij absoluut onvoorbereid was; anders had G. immers wel over betere materialen weten te beschikken. Iemand als Moira, zelf soldaat en die G. kende (den „edelen Gillespie” zooals de ridderlijke Nahuijs hem later betitelde, Herinneringen p. 82), moet dan ook onaangenaam zijn getroffen door R.'s poging om den heetbloedigen militair zijne eigene hoedanigheden toe te dichten en hem voor te stellen als een doortrapten veinzaard. Reeds 31 Oct. 1814 stierf G. den heldendood in den oorlog in Nepal, bij een aanval op Kalunga. The two houses of Parliament have voted a public monument to the Major-General and another to his companion in arms, Sir Samuel Gibbs, who fell about the same period, zegt Thorn p. 241. Dit monument bevindt zich in St. Paul's Cathedral te London; Mill, History VIII, 30 noot:

Glansbeek $(M$.$) van Heusden, bij de verovering Opziener van$ Parakanmoentjang; wordt 2 April 1812 als zoodanig bevestigd op 100 \$, zijnde 1e klas. Proc. 28 Mei 1813 heet hij pakhuismeester (sic) op Noesakambangan op hetzelfde salaris. Wordt als Opz. van Soekapoera vermeld in Proc. 28 Oct. 1814; wordt 12 April 1816 als zoodanig ontslagen wegens dronkenschap. 
Goldbach (Petr. Adrianus), geb. te Maurik 1767 als zoon van Daniel G., predikant aldaar, en Ida Maria Mom (later hertrouwd met J. L. Rockus te Amerongen), eene dochter van Gerrit Mom, heer van Maurik, en Ida Constantia Comans, die de dochter was van Dirk Comans en Ida Dudde, welke Ida Dudde de dochter was van Lambert Dudde \pm 1685 . Kwam op Java 1787 als Onderkoopman per Huisduinen, trouwt te Bat. 1789 met Adriana Elisabeth de Bruijn van Batavia. Hij was toen al Tweede Admin. der Westzijdsche Pakhuizen, hetgeen wijst op invloedrijke relaties; hij was dan ook een neef van den lateren G.-G. Wiese (Dr. de Roo I, 107). Zelf zegt hij ergens, dat het geslacht zijner moeder al 150 jaar in Indië is. G.'s schoonzoon was A. H. de Lanoy.

Bij de komst der Eng. was hij, ofschoon Daendels, dien hij een „monster” noemt (Dr. de Roo II, 530), hem niet zeer genegen was geweest, Landdrost van den Oosthoek, te Soerabaja; trad als zoodanig eerst 10 Nov. 1811 af, maar 22 Nov. schrijft hij dat hij, ofschoon zonder emplooi, het zijn plicht heeft geacht ,to accept the presidency of the Great Landraad". Den 9 Dec. 1811 schrijft de Regeer. aan Hope, dat G. is benoemd tot Magistrate of Sourabaya ,in which capacity he will execute the duties of Landrost to the extent that may be required by the Deputy Civil Comm., to whom he is immediately responsible and under such orders as he may hereafter receive from Govt. respecting the duties of Magistrate". Echter volgde het officieele schrijven eerst $21 \mathrm{Jan} .1812$; hij kreeg toen 400 \$ p. m. (later was het 300 \$) en werd tevens President of the Court of Requests. G. klaagde alras, dat Gibbs hem buiten alles hield; hij roemde zijn eigen vlijt in tegenstelling tot dien der Engelschen. Hij maakt den indruk van een braven knul, die wel wat voor land en volk over had; als rechter een stumper: wanneer een aangeklaagde niet verkoos te bekennen, stond G. volkomen radeloos. Engelsch verstond hij niet; hij klaagde in 1812 dat hij, door in Britschen dienst te gaan, gevaar liep van een ,civielen dood” in Nederl., waardoor hij ,,de eigendom van alle mijne bezittingen in Holland" zou verliezen. Van hun kant verweten hem de Engelschen, die hem Goldbag of Goldback noemden, dat hij prijsgoederen had afgegeven aan schuldeischers van het Gouvernement, zoodat er in 1813 kwestie van was om hem naar Engeland of te zenden. Den 5 Nov. 1812 werd hij ook benoemd in de Commissie voor den landverkoop te Soerab. Sedert April 1814 vinden we hem te Soerab. als Circuit Judge werkzaam. Hij overleed aldaar 10 Dec. 1815.

D1. 92. 
Zijne weduwe, die in de doodsadvertentie Anna Adriana de Bruijn heet en in de advertentie der executeuren Anna Elisabeth de Bruijn, overl. te Soerabaja 20 April 1838.

Grant Keir (Sir William), Major General, een vriend van Gillespie, arriveert te Bat. 15 Mei 1816 over land van Anjer; Lady Keir bleef tot Batavia toe aan boord van de Union. Dienzelfden dag nam hij zitting als First Member of Council en aanvaardde hij het legercommando. Lady Keir arriveerde denzelfden avond. Hij bleef op Java tot 29 Juni 1817 (Bat. Cour. van 5 Juli no. 17).

Grecne (G. P.), Lieutenant, wordt bij Gen. Orders 28 Juli 1812 belast met het toezicht op en onderhoud van the public roads and buildings in the territories of the Native Princes op 200 Sonat Roep. p. m. Elders blijkt, dat hij tevens belast was met the superintendence of the subsidiary native corps at the Courts (zie onder Dalton). Den 26 Mei 1813 schrijft Hope echter, dat hij G., die niet erg noodig was, heeft laten meegaan op de expeditie naar Sambas, en 17 Oct. 1813 vraagt dezelfde, of hij $\mathrm{G}$. thans mag gebruiken als waarnemend Secretaris ter vervanging van Eckford, hetgeen toegestaan moet zijn. Wordt bij Gen. Orders 1 Jan. 1814 Assistant to the Deputy Military Paymaster General; bij Gen. Orders 28 Juni 1815 naar Bengalen teruggeplaatst.

Grieve (C. D.) was anno 1815 oud 18 jaar en werkzaam onder den Resid. van Samarang, toen hij bij schrijven der Regeer. van 22 Juli werd benoemd tot Assistant to the Resid. of Grissee; hij trad als zoodanig op 22 Aug. en was belast met het Revenue Dept. op een salaris van 600 Java Roep. Maar reeds 2 Jan. 1816 wordt de Collector of Revenue te Soerabaja belast met de superintendence of the revenue collection of the districts of Grissee, waarna Grieve den 18 Jan. 1816 wordt overgeplaatst naar Soerabaja als Assistant in the Rev. Dept.; hier trok hij 800 Java Roep.; hij aanvaardde die betrekking 1 Febr. 1816; zijn werk aldaar heet (Proc. 14 April 1816) de voortzetting van dat van Eckford, die Collector was geweest. Raffles was thans tegen Collectors met een van den Resident onafhankelijk gezag. In 1820 woonde hij nog te Soerabaja als handelsman.

Haak (Diederik Willem Pinket van), geb. te Bat. 1779, waar zijn vader Secretaris der Hooge Regeer. is geweest. Trad Jan. 1798 in 
Nederl. in dienst als Onderkoopman en kwam 1 Sept. 1798 op Java. Was bij de verovering Landdrost van Japara; werd door de Eng. Regeer. voorloopig gehandhaafd, maar gaf 29 Nov. 1811 op last zijne betrekking over aan Doornik. Hope noemt hem in een schrijven van 1 Maart 1812 een vurig Franschgezind intrigant, met veel invloed onder den Inlander. Bij een brief van 24 Mei 1813 drukt de Resident van Samarang den Magistraat aldaar op het hart, om hem goed in de gaten te houden zoolang hij daar verblijft, in verband met zijne opzending naar Bat., daar het niet in de bedoeling ligt dat hij naar O. Java zal mogen terugkeeren. In Jan. 1814 vinden we hem te Kedoengbadak bij Buitenz.; 29 Sept. 1815 klaagt hij vandaar uit. dat hij nu al twee jaar geleden naar Bat. is opgeroepen, zonder opgave van redenen en tot zijne groote geldelijke schade. Op den rug van dit stuk zet Raffles eigenhandig: „,Mr. van Haak was ordered up from the Eastward on account of his avowed political principles". Comm.-Gen. benoemden hem tot Resident te Solo, waar hij 14 Aug. 1816 de Nederl. vlag heesch. Van Doren (Fragmenten I, 32) logeerde in 1823 bij hem te Japara, waar hij toen Resident was, en vierde er zijn verjaardag; hij noemt hem (bl. 34) een ,,algemeen bekend gastronoom". Vandaar dat hij bij zijn overlijden te Soerabaja 11 Maart 1840 tien onverzorgde kinderen naliet plus een faillieten boedel.

Hanson (J.) wordt nu eens Lieutenant, dan weer Captain genoemd; behoorde bij de Madras Native Infantry; komt hij voor als Major, dan beduidt dit: Brigade Major, waartoe hij Gaz. 5 Juni 1813 werd aangewezen. Tijdens de expeditie was hij Assistant Quarter Master General; hij werd bij de bestorming van Meester Cornelis gewond (Conquest p. 17 ; 68). Werd bij Gen. Orders 29 Sept. 1811 Military Secretary van Gillespie en onderscheidde zich bij de bestorming van den kraton van Djokja (Conquest p. 195). Bij het feest te Bat. in 1812 ter herinnering der verovering van Meester Cornelis zingt hij een lied. Wordt 11 Oct. 1812 ontslagen als Mil. Secretary. Gaat 1 Nov. 1812 met Eales naar Banka, doch komt reeds 20 Jan. 1813 ziek vandaar terug. Datzelfde jaar vinden we hem te Makassar; Proc. 3 Febr. 1814 wordt gesproken van eene zending van hem ,to explain the British Act of Parliament relative to the slave trade" (vermoedelijk naar Boni) in Jan. 1813; uit Gaz. 6 Maart 1813 blijkt, dat hij 3 Maart vertrok op H.M.'s sloop Hecate naar the Malay states beoosten Batavia en wel to promulgate the provisions of the late British Acts of Parliament on the subject of the slave trade 
and to introduce the complete abolition of that traffic as much as possible among those states.

Den 12 Mei 1813 komt hij te Bat. terug. Den 5 April 1814 gaat hij met Nightingall naar Bali en Boni en onderscheidt zich (Gaz. 9 April, 16 Juli en 12 Nov. 1814); den 1 Aug. 1814 komt hij terug. De Gaz. van 15 Oct. 1814 vermeldt, dat hij voor dienstzaken afwezig is, maar Proc. 28 Oct. 1814 wordt hij in plaats van Dupuy benoemd tot Superintendent of the Gov. Press, d.i. Editor der Java Gov. Gaz., zooals het in den betreffenden brief aan den Accoutant heet. Proc. 21 April 1815 wordt zijn salaris als zoodanig gebracht op 300 Java Roep. per maand, ingaande 1 Jan. 1.1. Uit Gaz. 15 April 1815 blijkt, dat hij ook Manager was van het liefhebberij tooneel te Bat. en er den Hotspur had gespeeld.

Den 17 April 1815 vertrok een Hanson naar Calcutta, die er 8 Juni aankwam; of dit op eene zending van onzen man doelt, blijkt niet. Proc. 10 Aug. 1815 wordt hij benoemd tot Resident van Cheribon; zijn opvolger als Superintendent der Press wordt Luit. Conroy; den 20 Aug. neemt hij Cher. over van Davies; tevens werd hij militair commandant aldaar, Gaz. 23 Sept. 1815; werd bij Gen. Orders 19 Dec. 1815 van dit laatste ontheven, doch Gaz. 13 Juli 1816 daarmee opnieuw belast. Hij bleef er Resident tot de teruggave. Verliet Java 1817. Den enorm hoogen aanslag der landrente, door Davy verricht, keurde Hanson absoluut verkeerd; daarentegen voerde hij op eigen gezag er nieuwe belastingen in. Blijkbaar een zeer bruikbaar persoon, van wiens verrichtingen men gaarne iets meer zou willen vernemen. Hij kwam later, toen Baud Gouverneur-Generaal was, op Java als Kolonel terug en stond ,verstomd over de zigtbare uitbreiding van alle cultures” en „over de vele blijken van welvaart en voorspoed, die hij allerwegen zag" (Mijer's Baud p. 446).

Hardy (François Emanuel), geb. te Breda, kwam als Assistent op Java 1803, ging Dec. 1807 naar Europa, kwam in Febr. 1811 met depêches van den Minister terug, en was bij de verovering Opziener bij de koffiecultuur. Zelf zegt hij in 1812, dat hij vier jaar heeft gediend ,as an officer in the British army" (denkelijk bij het corps Hollanders, dat deelnam aan de expeditie onder Abercromby naar Noord-Holland), en dat hij wegens zijne ,principles" aan vervolging is blootgesteld geweest. Hope ontsloeg hem als koffieopziener 10 Nov. 1811, maar diezelfde maand werd hij provisioneel Drost van Pekalongan; als zoodanig trad hij 23 Nov. op 
ter vervanging van Doornik; zijn salaris was 250 \$ en zijn titel ook wel „Resident” of „Landdrost”. Zijne nobele gevoelens toonde hij in Juni 1812, toen hij (Gaz. 13 Juni 1812) een groot feest gaf ter eere van 's Konings verjaardag, dat van 's middags 11 tot den volgenden morgen 6 duurde; en voor dat feest wilde hij, zegt hij, geene rekening indienen en geen ,farthing” ontvangen ,for having shown my attachement to my Sovereign and King”. Als vrijwilliger maakte hij zich verdienstelijk bij de bestorming van den kraton van Djokja (Gaz. 4 Juli 1812; Conquest p. 197). Bij besluit van 4 Sept. 1812 krijgt hij last ,to reorganize Pekal. on a new plan”; hij heet hier ,a gentleman whose qualifications and acquaintance with the native customs and habits render him particularly adopted for the undertaking, and in whose principles the utmost confidence may be placed”. Blijkbaar had hij Raffles een rad voor de oogen weten te draaien, want hij was (ofschoon Nahuijs, Herinneringen p. 66, hem „mijn vriend Hardy” noemt) zeer weinig bizonders en legde het thans af, zoodat hij bij schrijven van 19 Mei 1813 werd benoemd tot Assistant or Deputy Resident te Samarang op 300 \$; zijn werk zou zijn ,to reside constantly at Sam. and during my absence to carry on the local duties of the place", schrijft de Resident aldaar, conform bekomen last der Regeer. Den 5 Juni gaf hij Pekal. over aan Lawrence; den 11 Juni 1813 aanvaardde hij zijne betrekking te Samar. Reeds 31 Juli trad hij, bij afwezigheid van Garnham, als Resident van Samar. op; 1 Sept. 1813 gaf hij de residentie over aan Eales, gedurende wiens herhaalde afwezigheden Hardy weer telkens inviel, die bij schrijven der Regeer. van 26 Dec. 1813 bovendien tot Magistrate of the Town and Suburbs te Samar. werd benoemd, als opvolger van De Salis; zijn salaris was nu 400 \$. Resident Crawfurd klaagt Proc. 2 April 1814 heftig over Hardy's verwaarloozing der politie, terwijl deze laatste volhield, dat Crawfurd aan hem als Deputy Resident niets hoegenaamd overliet. In het laatst van 1814 ging $\mathrm{H}$. met verlof naar Batavia en bewerkte daar zijne benoeming tot Resident der Ommelanden (Proc. 6 Jan. 1815), ter vervanging van Ainslie; voorloopig nam Methven deze residentie waar, met last aan Hardy om vooreerst te Samar. te blijven. Eerst 19 April 1815 kwam hij te Bat., en 25 April gelastte de Regeer. hem de Ommelanden van Methven over te nemen. Zijne standplaats was Kampong Makassar. De opdracht van 10 Aug. 1815 zie onder Macquoid. In Oct. 1815 werd hij als opvolger van Macquoid Resident van Buitenzorg op 1.200 Java Roep., hetgeen hij bij de teruggave nog was en 
als hoedanig hij door Comm.-Gen. werd gecontinueerd. In 1821 wordt hij, als Resident van Kedoe, beschreven als iemand „die, bij eene zeer beperkte kennis van zaken, ten eenenmale de tact mist om met zijne ondergeschikte ambtenaren om te gaan" (Van de Graaff II, 180). Hij overleed 6 Febr. 1828 insolvent als Resid. van Rembang. Zie nog Van der Kemp, Herstel p. 274; 276.

Den 1 Aug. 1813 huwde hij te Samar. met M. M. Geyrold (Gaz. 14 Aug.). Eene C. G. C. Hardy trouwt te Bat. den 14 Mei 1834 met W. H. H. van Riemsdijk.

Harc (Alcxander) schijnt al van 1801 af te Malakka gevestigd geweest te zijn als handelaar. Blijkens bewaarde rekeningen was hij de agent tusschen Raffles en de inl. afgezondenen, die van Palembang, Atjeh, Bali Boeleleng vóór het afvaren der veroveringsexpeditie te Malakka waren gekomen. Een schip van hem, geladen met tin, werd in Maart 1810 door zeeroovers te Muntok genomen (Widow p. 44; 46; 47); hij vroeg dit later van de Prijsagenten terug, omdat het te Soerabaja was aangetroffen, Proc. 1 Nov. 1811. Hij heet door Minto en Raffles te zijn uitgenoodigd om met de expeditie naar Java te gaan (Widow p. 165), doch wij vinden in Oct. 1811, dat hij alhier opium had ingevoerd for self and captain Wood, dus veel overreding zal wel niet noodig zijn geweest; diezelfde maand zien we hem optreden als zaakwaarnemer van den Havenmeester van Malakka. Den 2 Nov. 1811 werd hij met Captain Phillips en Wardenaar gezonden ter overname van Palembang; zij kwamen den 6 Dec. 1811 van eene vergeefsche reis terug (Widow p. 110).

Volgens de Widow (p. 165) werd hij benoemd tot Commissioner for the Malay states and commercial resident at Bandjermasin. Wellicht dat deze benoeming dateerde uit den tijd vóór de verovering van Java; zij ging althans uit van Minto (ibid. p. 99); zij bleef dan echter ook daarna van kracht. Wij zien Hare in Februari 1812 uit het Dutch Secretary's office archiefpapieren ontvangen betreffende Bandjarmasin in 1802 en volgende jaren (later zond hij de stukken betreffende de opbraak van onze nederzetting te Bandjarmasin onder Daendels in Engelsch translaat naar Bat., Bijdr. 1898 p. 34; 38). Zijne benoeming tot Resident aldaar staat in Gaz. 11 April 1812. Een extract zijner instructie staat Proc. 10 April 1812: hij kreeg $500 \$$ p.m. van af 1 Febr. 1.1. since which time you have been engaged in the arrangements; verder $10.000 \$$ for the public service aldaar; voorts werd hem, gerekend naar den soberen maatstaf van 
dien tijd, een zeer overvloedig personeel toegevoegd. In Juni 1812 lag hij met de transportbrik Mary Ann te Samarang op weg naar die plaats; eerst eind Augustus schijnt hij vertrokken te wezen, en pas in Gaz. 12 Dec. 1812 vernemen wij de goede ontvangst aldaar van the British Resident and Commissioner Mr. Hare, die een contract met den Sultan had gesloten en hooge verwachtingen koesterde van eene Eng. vestiging ter plaatse. Hoe Hare het land Moloeka kreeg, blijkt in Bijdr. 1898 p. $11-14 ; 41 ; 43 ; 109 ; 110$. Of dit land heel geene toekomst zou hebben gehad, is niet uit te maken, zegt Van der Kemp (ib. p. 44), al zag de latere Engelsche commissie voor de opbraak er geen heil in en al waren de opgezetenen steeds van buiten af onderhouden (ib. p. 58). Eene beschrijving van dat land bij Van der Kemp, Herstel p. 374; 376. Over den persoon van Hare oordeelt dezelfde schrijver niet ongunstig; het was een energiek man; bepaalde verkeerdheden zijn nist tegen hem ingebracht (ib. p. $5 ; 7-10$ ); hij leefde op zeer grooten voet (Herstel p. 405); was persoonlijk bevriend met Raffles, doch overigens niet zeer geacht (Van der Kemp, N.-I. Bestuur p. 409). In een brief aan Captain Phillips spreekt Raffles dan ook van our friend Hare; in April 1815 behoorde deze tot zijn reisgezelschap. Hij prijst $H$. verder buitengewoon in zijn Discourse van 24 April 1813 (Verh. B. G. VII p. 27) als a gentleman whose desire after useful knowledge and whose zealous exertions in the cause he has undertaken, are perhaps unrivalled, and from the progress which he has already made in developing the general nature of the country and character of its inhabitants, the happiest results may be contemplated. He has already made several incursions and projects at an early period, penetrating far into the interior of the country. Under his enlightened administration the country subjected to Banjer Masin has been already reduced to order and regulation. Een zelfde toon, maar minder luid, klinkt in R.'s Discourse van 11 Sept. 1815 (Verh. B. G. VIII p. 13).

Ook onze archiefstukken zouden doen denken, dat Hare geen kwade kerel was. In een schrijven van 29 Maart 1815 spreekt hij met deernis over de in handboeien en ijzers naar Bandjarmasin gezonden veroordeelden, hunne sufferings in regard to food and accommodation, en de several necessaries which they ought not to be without but hitherto almost always have, from mere rice and water being all that is usually sent on board with them by the officers of Govt.; toen Commissarissen-Gen. zijne opgezetenen niet terug wilden hebben op Java, schreef hij 13 Jan. 1817: „That these poor people who 
went over with me and laboured in the jungles at Poolo Lampon from the first, whose uniform good behaviour has enabled me to effect all that I did and who I have been all along nursing with assurances, should now be sent to become convicts at Banca or Banda, would drive me half mad. I could not be happy after it and would rather throw half my fortune in the sea". Dit klinkt zeker goed, maar aan den anderen kant vergete men weer niet, dat Ross met Hare's eigen schip de Olivia veroordeelden naar Bandjarm. had gebracht (ook de brik Lady Bentinck was zijn eigendom). Den 31 Aug. 1815 bericht de Regeering, dat zij met Hare een contract heeft aangegaan om convicts van any port on Java te vervoeren hetzij naar Banka of Bandjarm. tegen 25 Java Roep. per kop, inclusief voeding. De betalingen van de Regeer. aan hem gingen steeds door de Residenten (waardoor de contrôle der onkosten van de vestiging onmogelijk werd); den 17 Juli 1813 moet de Resid. van Samarang hem 10.000 \$ betalen; den 11 Mei 1815 bericht de Resident van Pekalongan, dat hij hem 5.000 \$ heeft uitbetaald volgens verkregen order; den 1 Sept. 1815 gelast de Regeer. om hem te Grissee of te Soerabaja per maand 6.600 Java Roep. zilver uit te betalen van af 1 Mei 1.1. tot nader order. Den 11 Oct. 1815 geeft zij aan het Commercial Committee kennis, dat eene schuld aan Hare is voldaan met 3698 pikol koffie. Bij Proc. 1 Nov. 1813 werd aan Hare uitdrukkelijk toegestaan, te Bandjarm. ook als Resident handel te drijven; Proc. 28 Sept. 1815 heet het echter, dat hij hiervan geen gebruik had gemaakt (sic) en dat daarom zijn salaris was verhoogd tot het bedrag van dat van den Resid. te Makassar en dien op Banka, d.i. 750 Sp. Ds. Het een met het ander maakt een vreemden indruk, maar het Supreme Govt. keurde zijn particulieren handel goed.

Omtrent zijne verdere bemoeiingen blijkt uit het Batav. archief zeer weinig, maar genoeg om te doen zien, dat hij evenals Hunt en D. Ainslie en Crawfurd en Garnham met geheime opdrachten naar naburige eilanden belast werd. Volgens de Widow (p. 99) had Minto hem benoemd tot Resid. te Bandjarm. om den zeeroof tegen te gaan; elders echter (p. 110 noot) zegt die bron, dat Minto hem tot „Resident of Sambas" had benoemd (wat zeker meer op tegengang van zeeroof doelt). Nu blijkt uit den bundel papieren in zake Gillespie p. 319, dat Raffles in Oct. 1812 dacht, dat H. thans te Pontianak zou zijn en in elk geval met den Sultan aldaar in verbinding stond; verder dat $\mathrm{H}$. al in het bezit was van orders wat te Sambas zou moeten worden gedaan, wanncer dit eerst onderworpen was. Boven- 
dien zien wij uit de Gazette dat hij 20 Jan. 1813 (dus onmiddellijk na zijn contract met den Sultan van Bandjarmasin te hebben gesloten) van Batavia naar Pontianak vertrok, alwaar hij den 24 Febr. 1813 met een naar Sambas bestemd detachement Sepoys onder Captain Morris aankwam. En dat dit alles een onderdeel van een grooter plan vormde, blijkt uit een schrijven van den Resident van Makassar dd. 17 Jan. 1813 over onaangenaamheden met Koetei, waarin hij zegt, dat ,Mr. Hare, under whom I conceive all the Eastern part of Borneo to be", dat zaakje maar moet beredderen. Den 12 April 1813 verliet hij Pontianak. Den 22 Juli 1813 gelast de Regeer. hem, onmiddellijk van Bandjarmasin naar Pontianak te gaan, en 27 Dec. 1813 benoemt Raffles tot Resident aldaar W. Bloem, ondergeschikt aan Hare, die, blijkens Proc. 29 Maart 1815, aldaar als Commissioner optrad; eerst 29 April 1815 ontving Bloem den last om de nederzetting aldaar op te breken. Den 4 Aug. 1815 schrijft Hare, destijds te Bat., over eene overeenkomst van hem met den Sultan van Koetei betreffende British protection; hij zag Koetei aan voor a British dependency, zegt hij; thans echter heeft hij orders ontvangen restricting me from further expense or proceedings in pursuance of their (d.i. 's Gouvernements) former instructions with regard to the states of Borneo. Ik vermoed dus, dat Hare al te Malakka tot Commissioner for the Malay states was benoemd en wel door Minto zelf in verband met de expeditie tegen Java, en dat Raffles hiervan gebruik maakte om jaren achtereen in den Archipel te intrigeeren, precies op dezelfde wijze als hij later te Benkoelen deed; in eene Minute van 8 Sept. 1814 (Egerton p. 119) beweerde Raffles dan ook, dat hij, in zake de Buitenbezittingen, nog steeds handelde in my capacity as political agent for the Governor-General with the Malay states. De Directory for 1816 noemt Hare Resident (te Bandjarmasin) and Political Commissioner of Govt. for the native states on Borneo.

Hoe Hare Moloeka verloor, blijkt in Bijdr. 1898 p. 13-15; 51; 84 e.v. Zijne latere lotgevallen op de Kokoseilanden, waar hij met Ross in conflict kwam, zie aldaar p. 85; 91 e.v.; 154; Van der Kemp, Herstel p. 389 noot.

Wij vinden nog een David Hare in 1813 als juwelier te Bat., en Alexander's broer John Hare. Den 12 Jan. 1834 overlijdt te Bat. Alexander Hare junior, blijkbaar een volwassen persoon, die o.a. twee sloepen nalaat. 
Harris (Charles) is in Maart 1813 Lieutenant der Bengal artillery te Samarang en Assistant Commissary of stores. Wordt 27 April 1813 overgeplaatst naar Soerabaja; was daar, als Captain Lieutenant, belast met de affuitfabricage en werd door Raffles met ingang van 11 Jan. 1814 benoemd tot Superintendent der Munt aldaar op 500 Java Roep. In April 1814 ging hij met de expeditie naar Bali en Makassar. Uit mededeelingen van Inlanders vervaardigde hij eene beschrijving van Bali en Lombok, welke Crawfurd (History III, 533 Appendix) gebruikte voor zijn kaartje van die eilanden. Daarna keerde hij terug tot zijne bezigheden bij de Munt en trouwde 1 Sept. 1814 te Soerabaja met Wilhelmina Clara van Cattenburch geboren Barbier, eene rijke weduwe met 4 kinderen, die hem reeds 23 Mei 1815 gelukkig maakte met twee dochtertjes, waarop zij drie van haar eigen kinderen naar Europa expedieerde. Hij werd midden Juli 1815 ,with the native artillery under my charge" (zooals hij schrijft) naar Batavia opgeroepen om naar Bengalen terug te keeren. Nog in 1824 echter zit Charles Harris, gewezen officier der Hon. Comp. Bengal artillery te Soerabaja, waar 4 Juni 1824 zijne vrouw W. C. Barbier overlijdt. Zeer uitvoerige doodsadvertentie, die door hare overdrijving onaangenaam aandoet. Dat jaar vertrok hij naar Singapore; zijn boedel bleek later insolvent.

Den 8 Dec. 1826 wordt te Bat. gedoopt Clara Maria Harris, geb. te Soerabaja 10 Mei 1823, moeder Petronella Maria van Cattenburch, geadopteerd door Charles Harris. Dus Harris schijnt het met eene schoonzuster van zijne vrouw gehouden te hebben.

Harris (George), Captain Royal Navy, commanding H. M. Drake, heeft 23 Mei 1811 bij Rembang een gevecht met onze kanonneerbooten (Gaz. 25 Juli 1812), landt 30 Aug. 1811 te Soemenap, verovert Madoera en treedt op als Governor van dat eiland, alwaar hij bij zijn vertrek naar Europa, vermoedelijk in Oct. 1811, Maitland als Governor liet.

Hart (Richard), Lieutenant H. M. 78th regiment of Foot (Schotten), worlt zwaar gewond bij de bestorming van Meester Cornelis (Conquest p. 68), maar komt reeds 2 Maart 1812 voor als Assistant van den Resid. te Solo. Den 27 Sept. 1812 wordt hij benoemd tot lid der commissie voor de regeling der afgestane Vorstenlanden, als Assistant op 200 \$; hij was toen reeds belast met de overname van Blora en diende 1 Oct. 1812 een rapport daarover in; evenzoo ver- 
richtte hij den eersten aanslag in Djapan en Wirosobo; wordt bij schrijven van 11 Nov. 1812 benoemd tot Assistant to the Resident at Solo op 375 \$ p.m. Blijkens Proc. 18 Nov. 1812 was hij als zoodanig de opvolger van Eckford. In het voorjaar van 1814 nam hij blijkens Gaz. 11 Juni 1814 deel aan de expeditie naar Bali. Overigens bleef hij tot de teruggave Assistant te Solo. Maakt den indruk een zeer bekwaam man te zijn geweest.

Hartilieff (Johan Dirk) kwam in April 1810 op Java als Kapitein en Aide-de-camp van Daendels, die hem Hartje-lief noemt (Dr. de Roo, I, 340). Was einde 1810 plaatselijk adjudant te Grissee; neemt in Dec. 1811 het drostambt Grissee over van Van Nijvenheim; sedert heet hij Drost van Grissee; zijn salaris was 250 \$. Gibbs prijst hem zeer, 1 April 1812, en zegt dat $\mathrm{H}$. door zijne aanhankelijkheid aan de Engelschen has forfeited the good-will of a large proportion of his own countrymen. Zelf zegt $\mathrm{H}$., dat hij vroeger is geweest a British Captain (dus evenals Hardy; misschien hadden ze gestaan bij een Hannoversch of ander vreemd corps in Engelschen dienst) en in 1795 op half pay kwam. Overigens makt hij den indruk van een kruiperigen, vlegelachtigen kerel, een pummel van een vent. Bij schrijven van 11 Nov. 1812 wordt hij benoemd tot Resident van Rembang, ter vervanging van Van Lawick; hij geeft 24 Nov. 1812 Grissee over aan Van Nijvenheim en aanvaardt Rembang op 1 Dec. 1812. Proc. 24 April 1813 wordt hij benoemd tot Storekeeper and Civil Paymaster te Samarang op 250 \$; den 7 Mei 1813 geeft hij Rembang over aan Davidson. Proc. 1 Maart 1816 werd hij op verzoek als Storekeeper ontslagen; Proc. 9 Juni 1815 was hij als zoodanig geschorst wegens onbehoorlijk gedrag tegen den Resident, welke schorsing eenige dagen later werd opgeheven. Overleden te Samarang 27 Aug. 1818 oud 59 jaar. Zie nog Van der Kemp, N.-I. Bestuur p. 166; 389.

Hartsinck (Andrics), broer van den Vice-Admiraal Pieter H., geb. 1755 te Wageningen, op Java gekomen 1774, herhaaldelijk Resident, door Daendels benoemd tot Raad Extraordinair van Indië, wordt bij besluit van 23 Nov. 1811 Commissaris over het district Buitenzorg op 200 \$; hij heet ook Landdrost. Reeds 25 Nov. 1811 wordt hem wegens ziekte een Assistant toegevoegd, J. C. L. Meijer. Overlijdt 19 Dec. 1811 en wel insolvent (Gaz. 27 Maart 1813). Was eigenaar van Vlietlust en schoonvader van D. F. van Stralendorff, 
die in 1813 eene wagenverhuurderij had in de Buitennieuwpoortstraat. Deze was getrouwd met Joh. Susanna Hartsinck. Eene zuster van onze Andries Hartsinck, eveneens genoemd Johanna Susanna, werd moeder van de gravin D'Oultremont, die getrouwd is met Koning Willem I.

Harvcy (C.) komt 16 Sept. 1814 samen met Boggie van Calcutta, vertrekt 23 Jan. 1815 wederom met denzelfde naar Madras en komt 11 Maart 1816 alweer met Boggie (samen met Fendall) te Bat. terug. Vertrekt 4 Mei 1816 naar Samarang en wordt 29 Juni 1816 tot Assistant Resid. aldaar op 500 Java Roep. benoemd (Boggie was er toen Resident). Blijkbaar volgde hij Boggie als diens schaduw; misschien was hij een jeugdig familielid.

Hecrdt (Willom Hendrik van) van Zwolle, geboren 1789; of hij de W. H. Heert was, die 5 Maart 1805 werd aangewezen om met Elout en Van Grasveld naar Indië te gaan (Bijdr. 1864 p. 477), is mij niet bekend. Het kan zijn, dat hij familie was van Van Braam. Kwam op Java 13 Mei 1807. Einde 1810 is hij Gezworen klerk bij het kabinet van den G.-G. Den 12 April 1813 zegt Macquoid, dat hij Van Heerdt, die onder hem staat, heeft belast met de waarneming der betrekking van Villeneuve as my Assistant at Buitenz. Proc. 24 April 1813 wordt hij nu daartoe benoemd; het salaris was $150 \$$. Den 26 April 1814 krijgt hij salarisverhooging o.a. omdat hij zoo goed Engelsch heeft leeren spreken. Proc. 14 Oct. 1814 vraagt en verkrijgt hij echter zijn ontslag wegens onaangenaamheden met Macquoid; hij had in Holland, zegt deze, ,some relations now in high power", en werd daardoor baloorig; overigens dachten zoowel Macquoid als Raffles zelf zeer gunstig over hem (deze laatste echter veel minder gunstig in Proc. 11 Nov. 1814). Van H. daarentegen vond dat hij, door de gedurige afwezigheid van zijn chef, het te druk had, ,zijnde ik van gevoel, dat het lang genoeg gewerkt is van 's morgens 9 tot 's namiddags 4 à 5 uuren voor een tractement van maar 147 Sp. Ds. per maand". Den 22 Mei 1814 was hij te Bat. getrouwd met Minnie (Maria Wilhelmina) Dupuy, geb. 1792, overl. 1865, dochter van Pieter Philip du Puy, in Daendels' tijd vermoord als Commandeur van Bantam, oomzegster van N. Engelhard (zij ligt op Tanahabang begraven dicht bij Mevr. Raffles). Den 9 Aug. 1815 vertrok hij naar Europa, ofschoon zijne vrouw pas bevallen was. Uit papieren van N. Engelhard blijkt, dat hij in 1825 baron werd. In Gaz. 3 Aug. 1816 
komt een Count Von Heerdt voor als buitengewoon gezant van Willem I bij het Russische hof voor het huwelijk van den Prins van Oranje met Anna Paulowna; misschien was dit de broer, die volgens een brief van Engelhard Opperstalmeester was van ,de Koning van Holland". In 1822 woont onze Van Heerdt met zijne vrouw M. W. Dupuy te Soerabaja (Bat. Courant). Den 9 Nov. 1826 overlijdt te Probolinggo insolvent Willem Hendrik Baron van Heerdt oud 26 jaar (sic), Ommegaand Rechter; (als deze leeftijd juist was, zou hij op zijn 14e jaar getrouwd wezen). Was daartoe benoemd in 1821, zijnde Ass. Res. van Probolinggo.

Hesselaar (J.), gewezen officier, lang Luitenant bij de lijfwacht van den Soenan, bij de verovering Drost van Pasoeroean; overleed kort daarna. Was de schoonvader van C. Vos. Van hem dateert het fortuin der familie Lebret.

Heyland (J. H.), Lieutenant, daarna Captain, onderscheidt zich bij een gevecht aan de monding der Tjimanoek 31 Juli 1811 (Gaz. 25 Juli 1812); wordt bij General Orders van 22 Oct. 1812 benoemd tot Commandant der Djajang Sekars in the Samarang Division, als hoedanig hij reeds sedert 4 Aug. 1812 Hunter had vervangen. Wordt Proc. 5 Febr. 1813 benoemd tot Assistant to the Resid. van Kedoe op 150 \$, welk salaris 27 Dec. 1813 wordt gebracht op 300 \$. Hij beklom verscheiden malen den Sindoro (Widow p. 157 noot). Den 1 Nov. 1814 wordt hij belast met den anslag der landrente in Japara; hij arriveert aldaar 5 Dec. en bericht 27 April 1815 dat de aanslag voltooid is, waarop hem 17 Mei 1815 onder dankbetuiging voor de invoering van het detailed system gelast wordt naar Kedoe terug te keeren. In Japara teekende hij zich nu eens Ass. Res., dan weder: Commissioner of Revenue. Bij schrijven van 15 Juli 1815 werd hem op zijn verzoek toegestaan naar Bengalen terug te keeren, onder toezwaaiing van grooten lof en met betuiging van het leedwezen der Regeer., dat thans niet zullen kunnen worden voldaan those just claims to further distinction which your services would have ensured. Hij geeft nu zijn werk in Kedoe over aan Lloyd en vertrekt van Bat. 6 Sept. 1815 naar Calcutta, doch komt reeds 8 Jan. 1816 vandaar terug, wordt Proc. 2 Febr. 1816 opnieuw Ass. Res. in Kedoe, neemt echter reeds 1 Febr. 1816 zijn werk over van Murray en blijft hier tot de teruggave. Helaas kwam daarna aan het licht, dat hij in 1816 door valsche boeking het Gouv. had opgelicht voor meer dan 
50.000 Java Roep.; om zijne schurkerij te bedekken had hij de voornaamste boeken vernietigd, doch eene vergelijking der boeken van de districtsschrijvers bewees haar zoo zonneklaar, dat ook de Eng. Commissarissen haar moesten erkennen.

Higgins ( $C$. Th.), Luitenant, uit de Molukken overgekomen, vraagt om eene betrekking en wordt bij schrijven van 28 Juli 1813 op $150 \$$ benoemd tot Assistant to the Res. at Cheribon; de benoeming staat in Gaz. 31 Juli. Hij bleef hier tot 21 Dec. 1813, toen hij plaats maakte voor Ekeboom, om zelf als Captain Lieut. naar Bengalen te vertrekken. Zijne vrouw was Emma Maria Raban, dus de Resid. van Cheribon was denkelijk zijn schoonvader.

Holst de Wecrth (Otto) van Grootegast, zeeofficier, huwde in 1809 met M. M. J. Knibbe van Breda; was Drost van Pasoeroean in Nov. 1811; hij heet in 1812 ook wel Resident; zijn salaris bedroeg 200 \$. Den 27 Mei 1813 schreef de Regeering hem, dat Crawfurd ,will take charge of your Residency for the time being”, en dat hij dezen te gehoorzamen heeft; in Sept. van dat jaar werd Jourdan Resid. van Pasoeroean, en 15 Sept. deelt Raffles aan den Accountant de benoeming mede van Holst de Weerth tot Assistant and Storekeeper te Probolinggo, op zijn tegenwoordig salaris. Den 1 Nov. 1814 neemt hij op last der Regeer. de residentie Banjoewangi over van Davis; 22 Dec. 1814 gelast de Regeer. hem, deze residentie over te geven aan Roxburgh en terug te keeren to your former duties at Probolingo. Aldus geschiedt 17 Jan. 1815. In Mei 1815 is hij nog Assistant Resid. te Probolinggo; het jaarboekje voor 1816 noemt hem Assistant and Storekeeper. Overlijdt te Soerabaja 3 Oct. 1817 als Ontvanger der Landelijke Inkomsten in Bezoeki, Probolinggo en Panaroekan.

Homer (Arthur Aston), Lieutenant 6th Battalion Bengal Volunteers, begeleidde de Cheribonsche Sultans, die naar Buitenzorg waren opgeroepen, naar hun land terug en bericht 17 April 1812, dat hij aldaar over zee met hen is angekomen. Hij schijnt dus behoorlijk Maleisch te hebben gekend, en komt dan ook weldra als tijdelijk Maleisch translateur in de Vorstenlanden voor, op 200 \$. In Sept. 1812 is hij op hetzelfde salaris Assistant bij de Commissie tot overname der afgestane Vorstenlanden; schijnt speciaal onder Crawfurd in Patjitan werkzaam geweest te zijn en treedt 15 Jan. 
1813 op als Assistant to the Resident at Djocjo, en opvolger van Deans. Toen Crawfurd 24 April 1813 naar Bat. ging, werd $\mathrm{H}$. waarnemend Resident. Bij schrijven van $30 \mathrm{Juli} 1814$ benoemt de Regeer. hem tot waarnemend Resid. van Tegal, ter vervanging van Davies; 22 Aug. 1814 trad hij aldaar als zoodanig op; Proc. 21 Oct. 1814 bevat zijne benoeming tot Resident aldaar. Proc. 26 April 1816 wordt hem op verzoek toegestaan om wegens ziekte naar Europa te vertrekken; den 29 April geeft hij Tegal over aan Ivatts en arriveert 7 Mei 1816 te Batavia.

Hood (Sir Samuel), Vice-Admiral and Commander in chief of H. M. naval forces in the East Indies, komt met de Minden 29 Juni 1814 te Samarang. Deze zeeheld wenschte over Java te reizen, zoodat 3 Juli 1814 eene circulaire aan de Residenten ging om hem en zijne officieren op alle wijzen te helpen. Hoe zenuwachtig dit bezoek Raffles maakte, is nog te zien uit de talrijke doorhalingen (zeer in strijd met zijne gewoonte) in een briefje aan den hoogen gast. Van uit Samarang bezocht hij eerst Soerabaja, Madoera enz. en kwam er 6 Juli terug. Den 7 Juli ging Garnham met Hood van Sam. naar de Vorstenhoven; den 20en kwam Hood te Buitenz., werd den 23en met veel vertoon te Bat. ingehaald, vertrok daarna over land naar Anjer, waar hij zich weer inscheepte. Hij overleed te Madras 24 Dec. 1814. Zijne levensbeschrijving staat in Gaz. 18 Maart 1815. Niet te verwarren met zijn naamgenoot, den Admiraal die Toulon tegen Bonaparte verdedigde, wiens biographie staat in Gaz. 22 Juni 1816.

Hope (Hugh) was een broer van Sir John Hope, een generaal onder Wellington in Spanje (naar Elias te oordeelen geen lid der Hollandsch-Engelsche familie Van der Hoop) en volgens Minto (bij Boulger p. 97) a tolerable Dutchman (d.i. kenner van de Ned. taal) with excellent talents and habits of business.

Toen Raffles zich in 1809 te Calcutta bevond, ontmoette hij aldaar Hope, die van Mauritius kwam (Widow p. 26); deze behoorde tot het Bengal civil establishment en ging daarna met Lord Minto naar Java ,in the Dutch department” (Widow p. 27), iets wat eenigszins zonderling klinkt, omdat wij later bespeuren, dat $H$. geen of zeer weinig Hollandsch verstond. Tijdens de expeditie fungeerde hij als Deputy Secretary to the Gov. General; dus ondergeschikt aan den Secretary Raffles; toen deze den 11 Sept. 1811 Lieut. Gov. werd, trad Hope op als Secretary. Betreffende zijne benoeming tot Civil 
Commissioner is van belang een brief van Nic. Engelhard aan Janssens dd. 6 Juni 1830, waarin hij dezen in herinnering brengt, dat Daendels tegenover J. zijne opheffing van het Gouvernement van Java's N. O.-kust had betreurd onder toevoeging dat, ware hij aan het bestuur gebleven, hij dit zou hebben hersteld; J. herinnert zich immers wel, ,dat ik daarover aan Mylord Minto van advies gedient heb, dat door Z. E. in Uwe Exc. handen is gesteld, en dat hetzelve door Uwe E. op het kragtigst is ondersteund; ten gevolge daarvan is dan ook de residentie Tagal met de residentie Cheribon verenigd en over Samarang en onderhorigheden benoemd is een Commandant Civil, zijnde de Opperkoopman (dus Senior merchant) Hoope". De instelling dateert van 18 Oct. 1811; Minto bepaalde daarbij niets, dan dat ook de Oosthoek onder het ressort van den Civil Commissioner zou behooren, dat deze rang zou hebben na den Legercommandant, geene wetgevende macht mocht uitoefenen, geene vonnissen revideeren, geene openbare werken ondernemen, geene nieuwe ambten creëeren of belangrijke systeemveranderingen instellen. Bij vacature der landvoogdij zou de Civil Commissioner onder nadere goedkeuring als zoodanig optreden. Zijn salaris werd bepaald op 16.000 \$ per jaar, dat van zijn Assistant op 750 Sicca Roep. per maand. Minto had opzettelijk nagelaten, de plichten van den Civil Commissioner te omschrijven, om den Lieut. Governor de vrije hand te laten. Den 21 Oct. 1811 (dus na Minto's vertrek) legde Hope den eed af als Civil Comm. of the Eastern districts of Java; dienzelfden dag gaf de Regeer. aan de Landdrosten daarvan kennis (zonder echter eenig voorschrift te verstrekken aangaande hunne verhouding tegenover hem) en ging hij scheep; den 27 Oct. berichtte hij zijne aankomst te Samarang, en den 31 Oct. dat hij dezen dag had assumed charge of the duties of Landdrost for the district of Samarang; Middelkoop bleef echter tevens nog tot 15 Nov. als zoodanig fungeeren. Den 1 Nov. 1811 werd Hope's salaris bepaald op 1.400 \$ per maand.

Zijne ongedateerde instructie, door Raffles bij zijn vertrek opgesteld, bevat betreffende zijne bevoegdheid letterlijk niets dan de woorden: You are to consider all civil affairs to the East of Tagal (uit een vroeger stuk blijkt, dat Raffles den 22 Oct. 1811 van plan was, Hope's ressort te doen strekken ,eastward of Cheribon” en 1 Aug. 1812 werd Tegal inderdaad onder de Eastern Districts gebracht) under your immediate management, subject to the orders and instructions of Government"; voorts dat hij tevens zou fungeeren als Landdrost van Samarang (welke betrekking werd afgeschaft), 
en dat ,all reports” uit Pekalongan naar Samar. zouden worden opgezonden, dat er immers vlak bij lag (waaruit dus zou volgen, dat de andere residenties dit niet, of niet uitsluitend, behoorden te doen, doch ook direct met de Regeer. konden of moesten correspondeeren); te Soerabaja zou Gibbs zetelen als Deputy Civil Comm., doch ook omtrent diens bevoegdheid blijkt niets. Daendels had, zooals de instructie voor den Deputy Accountant te Soerabaja dd. 14 Febr. 1812 herinnert, den Oosthoek tot een afzonderlijk Landdrostambt gemaakt; de Britsche Regeer. echter maakte den Deputy Commissioner weder ondergeschikt aan een chef te Samarang. Hope kreeg geen enkelen last mee, dan om het personeel te besnoeien (onder bepaling, dat van af $1 \mathrm{Dec}$. het niet door de Regeer. gesanctionneerde personeel zou zijn ontslagen) en rapporten in te dienen omtrent den staat van zijn ressort. Wel werd gesproken van nadere instructies, welke hem zouden worden gegeven, doch niets daaromtrent verluidt, behalve dat hij geene uitgaven mocht doen zonder goedkeuring van de Regeering; evenzoo benoemde en ontsloeg hij zijne ambtenaren alleen provisioneel. Eerst in Aug. 1813 zond Raffles hem een extract of a dispatch from the Right Hon. the Gov. Gen., waarin zijne plichten werden aangegeven, van welke hij dus, naar het schijnt, tot dusver onkundig was gelaten. Wanneer men zich nu bijv. herinnert dat, zoolang er een Gouverneur te Samarang had gezeteld, de Residenten aan de Vorstenhoven aan dezen ondergeschikt waren geweest, wordt Raffles' stilzwijgen omtrent H.'s bevoegdheden nog raadselachtiger. Vermoedelijk had deze de instelling van een Civ. Comm. met leede oogen gezien en had hij zich van meet af voorgenomen hem onmogelijk te maken, iets wat niet veel moeite kon kosten, gegeven 's mans onberadenheid, spilzucht, goedmoedigheid en middelmatige talenten; hoe vager dus de instructie, hoe beter. Al dadelijk, terwijl Hope nog op reis naar Samar. was, gelastte Raffles den Res. van Djokja om on all subjects of political importance direct met hemzelven te correspondeeren, met $H$. enkel over zaken of a local nature; $H$. schrijft dan ook 29 Febr. 1812: I never interfere in the affairs of Solo; daarom zendt hij ook brieven, door den Rijksbestierder buiten den Resident om tot hem gericht, terug. Daarentegen stak H. reeds 19 Nov. 1811 in zee met eene proclamatie, waarbij hij ter eere van R.'s ambtsaantreding pardon schonk aan crimineele gevangenen; ofschoon dit heette te geschieden namens de Regeer., blijkt van een dergelijk te Bat. afgekondigd pardon niets. Diezelfde maand herstelde hij op eigen gezag de kopermunterij te Soerabaja. Bij brief van 3 Jan.

D1. 92. 
1812 schrijft Hope doodbedaard aan den Landdrost van Pekal., dat de wagenpost maar eens per week zal gaan, om de bevolking te sparen. In Jan. 1812 ontvangt hij een schrijven van een Radja op Bali, die betrekkingen met het Gouv. wil aanknoopen, en antwoordt daarop. In Febr. kondigt hij op eigen gezag proclamatiën af, waarbij hij zich verbindt tot het opkoopen van oud Bataviaasch credietpapier tegen den officieelen koers, die ver boven den reëelen was; hij stelt daarentegen buiten werking een artikel van eene Gouvernementspublicatie betreffende het Probolinggo papier; hij verklaart biljoen de koperen bonken van zekere jaren en verbindt zich tot het inkoopen daarvan tegen een vasten prijs, alles heel goed bedoelde en heel gevaarlijke eigendunkelijkheden, die de Regeer. hem onmiddellijk noodzaakte terug te nemen. Het nut van zijne betrekking moest bovendien steeds problematischer schijnen, nu de correspondentie der Regeer. met de Residenten van zijn ressort door zijne bemiddeling, en dus met noodeloos oponthoud, geschiedde: wij zien dan ook reeds in Mei 1812, dat Flint gemachtigd wordt als Superintendent der Houtbosschen direct met de Regeer. te correspondeeren. Daarentegen had Hope in Jan. 1812 eene publicatie tegen opiumsmokkelarij aan de Regeer. toegezonden, waarvan deze geene notitie nam, totdat de toepassing dier bepalingen haar misnoegen opwekte. Den 30 April hield Hope zelfs eene vergadering van den reeds afgeschaften Grooten Landraad, welks handelingen den 16 Mei dan ook door de Regeer. ongeldig werden verklaard. Hope’s nuttigste bezigheid was misschien die verbonden aan het Treasury and Civil Payoffice, waarmee hij in Nov. 1811 was belast geworden; den 24 Maart 1812 werd hem echter streng verboden, wissels op Bat. af te geven, en juist zijne geldelijke verantwoordelijkheid was hem zeer onaangenaam. Voor beide partijen was het wellicht eene uitkomst, toen na den val van Djokja (20 Juni 1812) Hope met eene politieke opdracht naar Solo werd gezonden, waarna den 16 Juli 1812 eene eigenaardige wisseling van personen plaats vond: Adams wordt opvolger van Gibbs te Soerabaja, dus, zou men zeggen, Deputy Civil Commissioner; de opengekomen residentsplaats te Solo wordt aangevuld met Hope op 600 \$ boven zijn tegenwoordig traktement, en tevens wordt Lawrence Resident van Samarang, waarmee derhalve H.'s bezigheden als Resident, speciaal die met 's Lands kas aldaar, vervielen; bovendien verloor hij zijne rechterhand, den knappen Assey, en werd voorgeschreven, dat de Civil Commissioner weliswaar de general and local superintendence zou blijven uitoefenen over zijn ressort, maar dat 
de Residenten voortaan direct met de Regeering zouden correspondeeren, onder anbieding van copie aan den Civ. Comm. Den 31 Juli aanvaardde H. zijne nieuwe betrekking. De bedoeling van deze verwisseling van personen blijkt pas uit een schrijven van Raffles dd. 10 Juni 1813 aan Adams: On the appointment of Mr. Hope to be Resident at the Court of Solo and on the appointment of a Resident at Samarang the office of Deputy Civil Commissioner was considered to have ceased. Wezenlijk afgeschaft was de Deputy echter nog zoo weinig, dat Raffles zelf den titel nog in Sept. 1812 bezigt; deze werd eerst veranderd in "Resident of Sourabaya” bij eene publicatie van 15 Sept. 1812, ja, uit artikel 1 der ongedateerde Minute van Raffles (opgenomen in Proc. 15 Sept. 1812) zou men opmaken, dat diens bedoeling in Aug. 1812 oorspronkelijk was geweest om nog een tweeden Deputy Civil Commissioner aan te stellen, en wel te Samarang, met gelijke bevoegdheden als dien te Soerabaja en een even ruim ressort. Aan het Opperbestuur had R. den 8 Aug. 1812 geschreven, dat door de nieuwe regeling de Civil Comm. meer tijd zou krijgen voor general superintendence, immers hij was thans relieved from all details whatever, retaining the same general controul and superintendance as before, precies dus alsof de residentie Solo eene sinecure was. En dit officieel schrijven moet ongetwijfeld begeleid zijn geworden door een particulieren brief, waarin over H.'s aanmatigingen werd geklaagd, denkelijk onder toevoeging der concept-instructie voor de Residenten, die nog in Proc. 15 Sept. te vinden is. Reeds bij schrijven van 31 Oct. 1812 keurde het Opperbestuur de benoeming van Hope te Solo goed, en zeide verder: The arrangements made by you for the administration of the Eastern Districts appear to us judicious and we have sanctioned them accordingly. The officers in charge of those districts will henceforward act under the immediate authority of your Government, and altho' it will no doubt be convenient and proper that the Civil Commissioner should continue to exercise a general superintendence in the districts in question, it was very desirable, we think, that you should establish a more direct controul over the local authorities, and we consider this system as an important improvement on the general administration of the Island. Bij de 15 Sept. 1812 vastgestelde Instructions to the Residents was dan ook bepaald (art. 1 en 2), dat dezen onmiddellijk met de Regeering zouden correspondeeren en van haar hunne orders zouden verwachten, van den Civ. Comm. enkel diens opinion, diens requisitions and instructions, en dat zij hem such 
reports and information zouden aanbieden as he may require from time to time. Bij de publicatie van 15 Sept. 1812 betreffende de Residenten werd o.a. vastgesteld: The Deputy Civil Commissioner will in future be styled Resident of Sourabaya. Each Resident is the local chief civil officer of Govt. in his district, the whole of the Eastern Districts in the Island continuing to be under the general superintendance of the Civil Commissioner. Waar verder in de instructions van dien datum van zijne betrekking wordt gesproken, blijkt dat er van gezag enkel eene schaduw aan Hope overbleef. En dat juist hierom die instructies werden opgesteld, volgt uit de omstandigheid, dat zij alléén golden voor de residenties onder Hope's ressort, niet bv. voor Cheribon. Voorloopig kreeg deze de handen vol door zijne benoeming als een der drie Commissarissen voor de regeling der afgestane Vorstenlanden, die tot 28 Jan. 1813 fungeerden. Middelerwijl werd hij steeds uiterst coulant behandeld. Bij schrijven van 24 Maart 1812 was hem een tafelgeld toegekend van 1.000 Sicca ropijen per maand, ingaande 1 Jan. 1.1. (het Supreme Govt. gelastte later dit terug te storten van af zijne benoeming te Solo) en bovendien kreeg hij nog ruim 10.000 \$ uitbetaald voor receptiekosten te Samarang tijdens de expeditie tegen Djokja in Juni en Juli 1812; bij extra gelegenheden, zooals voor een feest op den verjaardag des Konings of groote recepties te Solo, kreeg mijnheer nog wel eens een 1.000 \$ toegestopt. Om de kroon op alles te zetten: hij trok in $1812 \operatorname{nog} 16.000$ \$ uit de Java Lottery.

,As for the prizes great and small,

The Government has got them all,

God knows what they 've been doing"

klaagt een teleurgesteld medeloteling in de Gaz. van 24 Oct. 1812. $\mathrm{Hij}$ voerde dan ook een grooten staat. Te Samarang bewoonde hij Bodjong; wij hooren dat bij zekere gelegenheid aldaar fifteen officers with their concubines logeerden for about a month; many articles in the house were in consequence lost or broken, as the house was crowded every day. Een deel van zijn inventaris alhier werd later voor ruim 5.000 \$ door het Gouv. overgenomen. Er wordt ergens paardetuig van hem vermeld, waar voor $200 \$$ aan zuiver zilver aanzat. Bovendien had hij een buitenverblijf te Kopeng bij Salatiga. $\mathrm{Na}$ zijne benoeming te Solo woonde hij veelal in die residentie en dateerde dan zijne brieven toch Civil Commissioner's office; hij had toen bovendien nog een buitenverblijf te Selo, bewesten den weg 
naar Samarang hoog den Merapi op, waar een Europ. tuinier woonde ${ }^{1}$ ), nog een buitenverblijf te Kletjo, wat bewesten de hoofdplaats, en een te Gintoengan of Banjoekoening (bij Ambarawa aan de zuidhelling van den Oengaran, beschreven in Gaz. 27 Aug. 1814). Dit hoorde onder Samarang; onder Solo hoorde nog het landhuis Kentengan, ergens down the river, dus denkelijk bij de monding der Kenteng. Kletjo diende voor recepties; het was evenals Selo zeer eenvoudig. Hope's personeel daarentegen was naar gewoonte zeer gering; nadat zijn Assistant Assey hem in Juli 1812 was ontnomen (zie boven) was Eckford zijn secretaris; daarna Loudon zijn factotum.

Intusschen verbeterde zijne positie er niet op. Zijne correspondentie met de Regeer. als Civil Comm. werd steeds schaarscher en van minder belang; dikwijls bleven zijn brieven onbeantwoord; de Regeer. gaf de voorkeur aan eene correspondentie met de Residenten. Dit verergerde nog, toen Hope geen groot voorstander der invoering van de landrente bleek en het ergste vreesde van eene vermindering van het gezag der Regenten; na lezing van Raffles' Minute van 14 Juni 1813 over het nieuwe stelsel schreef hij koeltjes terug: „It appears unnecessary to offer any remark". Hij werd dan in 1813 ook stelselmatig buiten deze aangelegenheden gehouden; het heette dat hij toezicht uieoefende, maar alles werd afgehandeld tusschen Raffles en de Residenten; Hope kreeg enkel afschriften van de gewisselde stukken, hetgeen tot niets leidde dan onnoodig schrijfwerk. In Mei 1813 tijdens het Probolinggo-oproer, negeerden de betrokken Residenten hem volkomen, tot zijne groote ergernis en in strijd met art. 30 hunner instructie, terwijl de Regeer. niet hem met een onderzoek naar de aanleiding van dat oproer belastte, maar Crawfurd; in Juni werd hij evenzoo geignoreerd bij Crawfurd's regeling in Probol. en Bezoeki, en zoo was er meer, waarvan hij enkel kennis kreeg, wanneer de beslissing reeds was gevallen. Het hing echter feitelijk vooral van de Residenten af, welke positie $H$. zou innemen; zoo richtte die te Banjoewangi zich in 1813 nog steeds naar zijne orders. Adams te Soerabaja ontvangt in Maart en April 1813 totaal 11 brieven van Hope en schrijft hem er 12, waaronder 6 kennisgevingen van ontvangst. Ofschoon dus de Civ. Comm. volstrekt niet op kwaden voet met den Lieut. Gov. geraakte (met Kerstmis 1812 logeerde hij

\footnotetext{
1) Vermeld bij Van Doren, Reis II, 279: Selo „een landhuis op den verbindingsrug van den goenong Merbaboe en Merapi"; daar woont 1823 een oude Duitscher ,als tuinman”; er was een „groote kachel”.
} 
te Buitenz. en Febr. 1813 was hij daar nog; Raffles zond hem zelfs in commissie naar Tjiandjoer om klachten tegen Gillespie te onderzoeken), zijne persoonlijke belangen steeds uiterst coulant werden behandeld en hij niet zelden complimenten kreeg en zijn advies werd gevraagd, moest hij gaandeweg voelen, hoe absoluut scheef zijne positie was geworden, speciaal na $16 \mathrm{Juli}$ 1812. Om daar verbetering in te brengen, vroeg hij 14 Aug. 1813 zijn ontslag als Resid. te Solo; maar toen de Regeer. hem den 20 Aug. beduidde, dat zijne positie als Civ. Comm. toch precies dezelfde zou blijven, trok hij 27 Aug. dit verzoek weer in. Zijne gezondheid, die niet al te best was, zal er wel niet op verbeterd zijn. In October kwam het tot eene uitbarsting.

Zooals wij onder de personalia van Macquoid bespeuren, werd deze gunsteling van Raffles in Aug. 1813 belast met eene zending over Java tot overname der zoutpachten. Hiervan werd Hope door de Regeer. in kennis gesteld bij een schrijven van 10 Aug. Maanden lang bleef Macquoid vervolgens in Midden- en O. Java werkzaam, en in Oct. ontmoette hij Hope te Solo, vanwaar hij naar Samarang vertrok. Hier schijnt hij den brief van 8 Oct. te hebben gevonden, waarbij hij aan Resident Eales werd toegevoegd voor den anslag der landrente; hij ging toen op Bodjong logeeren, ondanks dat $\mathrm{H}$. een schriftelijke order had achtergelaten om aldaar geen gasten te huisvesten en ondanks de uitdrukkelijke bepaling der instructie voor de Residenten (art. 10), dat dezen geene ambtenaren behoefden te logeeren; iemand van zijn rang, zei Macquoid, kon niet zijn intrek in de herberg nemen. Ook had Hope zelf, toen hij om een tafelgeld vroeg, geschreven: Government would be by no means pleased to find that their first officers should be sent to an inn. Mac geliefde Hope's verbod echter te beschouwen als speciaal tegen hèm gericht en schreef hem nu een paar nijdige brieven, waaruit deze voor het eerst vernam, welke nieuwe opdracht de gunsteling weer had gekregen binnen zijn eigen ressort. Daarop volgde een schrijven van den Civil Commissioner dd. 17 Oct., waarbij deze hem schorste in al zijne ambtsbezigheden in het ressort beoosten Cheribon! Waarop Mac naar Buitenz. toog en daar de trompet stak over this extraordinary exertion of a delegate authority. Natuurlijk werd $\mathrm{H}$. toen genoodzaakt zijn besluit in te trekken, maar hij vond het thans noodig, schreef hij 4 Nov., dat deze belangrijke aangelegenheid naar Bengalen werd gerenvoyeerd. Dezo brief bereikte Raffles den 6 Nov. te Cheribon, die goedvond er uit te lezen, dat the judgement and authority 
of this Govt. to decide in a case perfectly local, has been called in question en het daarom noodig oordeelde, thans het voortbestaan van den Civil Commissioner aan het oordeel van het Opperbestuur te onderwerpen; inmiddels kon Hope dan Member of Council worden ter vervanging van Muntinghe. De Council bleek het met deze opvatting geheel eens te zijn, maar zonder het oordeel zijner zoogenaamde „Colleagues” af te wachten, schreef R. dienzelfden dag aan Hope, dat hij benoemd werd tot Provisional Member of Council met behoud van zijn salaris als Civil Comm. en zelfs van dat als Resident te Solo, totdat hij in laatstgenoemde betrekking zou zijn vervangen. Ook zijn tafelgeld ${ }^{1}$ ) ging door. Het Supr. Govt. verklaarde zich bij schrijven van 23 April 1814 volkomen tevreden met Hope's benoeming tot Raadslid en verklaarde tevens de betrekking van Civ. Comm. voor afgeschaft; als Raadslid zou $\mathrm{H}$. echter zijn vroeger salaris behouden en men achtte het wenschelijk, dat hij nu en dan eens zijn vorig ressort zou bezoeken ${ }^{2}$ ). Den 9 Dec. 1813 kwam H. te Bat. en nam den 15en zitting in Rade; werd Gaz. 18 Dec. benoemd tot President van het Revenue Committee en Gaz. 12 Maart 1814 (natuurlijk met een extra salaris van 1.760 Java Roep.) tot President van het Supreme Court of Justice. Eigenaardig is, dat hij tot in Maart 1814 nog steeds rapporten van zijne vroegere Residenten ontving. Eerst bij circulaire van 9 Aug. 1814 vernamen zij de opheffing der betrekking van Civil Commissioner, doch het ambt had sedert lang zoo weinig te beduiden gehad, dat de intrekking heel geene nieuwe voorzieningen noodig maakte, behalve een last om de archieven naar Bat. op te zenden, tengevolge waarvan een deel hiervan bewaard is gebleven. Met Raffles was $H$. steeds heel wel; uit Addison (p. 365) zou men opmaken, dat hij in April 1814 te Buitenz.

1) Bij schrijven van 7 Nov. 1813 vroeg Hope, dat dit ondanks het besluit van het Supr. Gov. mocht worden gecontinueerd in the event of my continuing to fill the double situations of Civil Comm. and Resident. Bij Proceed. 24 Nov. 1813 wordt dit behandeld (dus toen hij reeds was benoemd tot prov. lid van den Council) en besloten zijn verzoek te ondersteunen bij het Opperbestuur (hetwelk had gelast, dat zijn tafelgeld als Civ. Comm. moest ophouden sedert zijn benoeming te Solo) en het voorloopig te blijven betalen. Dat Hope steeds het tafelgeld bleef trekken, volgt ook daaruit, dat eerst bij Proc. 14 April 1815 de Res. van Samarang een tafelgeld kreeg (the table allowance which was granted to the Civil Commissioner), ofschoon hij reeds 6 Dec. 1814 was benoemd.

2) Ook dit had Raffles echter reeds ondervangen, door bij de Regulation 11 Febr. 1814 art. 171 aan de Circuit Judges(!) op te dragen om te rapporteeren aangaande den staat der verschillende residenties waar zij rechtsdag hielden en zelfs voorstellen ter verbetering in te dienen. 
logeerde; deze zegt ook (p. 376), dat Hope in de zaak van Gillespie's aanklacht ten sterkste vóór den Lieut. Gov. partij trok.

Hij woonde nu de raadsvergaderingen zeer geregeld bij, totdat de zitting van 19 Aug., waarin een brief van het Opperbestuur werd behandeld, waarbij niet langer hij doch Nightingall tot eventueel opvolger van Raffles werd benoemd, hem ongesteld maakte; den 7 Oct. vroeg en kreeg hij van Raffles verlof om tot herstel van gezondheid voor 4 maanden naar China te vertrekken (dat gebeurde wel meer $\left.{ }^{1}\right)$ ) en den volgenden dag ging hij reeds scheep. Uit Canton vroeg hij bij brief van 6 April 1815 om 6 manden verlenging van verlof, hetgeen door de Regeer. voor notificatie werd aangenomen; het werd 9 Dec. 1815 voor hij terugkwam en 12 Dec. voor hij weer zitting nam, doch hij werd al gauw weer ziek en klaagde reeds 20 Dec., dat hij voor gezondheid zou moeten repatrieeren. Den 28 Dec. gaf hij het presidium van het Supreme Court aan Muntinghe over. Den 1 Jan. 1816 erkende Raffles ook de noodzakelijkheid van zijn vertrek, zwaaide hem hoogen lof toe voor zijne vroegere medewerking en liet hem 8 Jan. naar Anjer vertrekken om de van China verwachte schepen te verbeiden; eerst 5 Febr. kon hij scheep gaan. Bij een brief uit Straat Soenda vroeg hij pas zijn ontslag als Raadslid, en Proc. 15 Febr. 1816 werd besloten, dat zijn salaris zou worden uitbetaald tot op den dag zijner inscheping.

De Gaz. van 16 Dec. 1815 bevat de advertentie zijner vendutie, waaronder: the house and extensive premises belonging to Hugh Hope Esq. situated next to the Government-house at Ryswick.

Hopkins (D.), geb. in Schotland 1770, was in Bengalen Assistant Surgeon geweest en daarna op Banda Superintendent der nagelteelt. Minto schrijft 6 Dec. 1811, dat hij hem verzocht heeft het beheer der houtbosschen op Java op zich te nemen. Uit de Molukken vertrok hij in 1812 per Wellesley naar Bengalen; in Gaz. 10 Oct. 1812 leest men, dat hij in Juni 1812 te Calcutta is aangekomen als Conservator of Forests on Java. Bij brief van 31 Juli 1812 gaf het Opperbestuur kennis, dat het hem had benoemd tot Superintendent General of Teak forests op Java op 1.000 \$ per maand. Begin Febr. 1813 komt hij eindelijk op Java en wordt nu Proc. 9 Febr. 1813 belast

1) Zelfs uit Bombay ging men wel ter herstel van gezondheid naar China; zoo in 1812 een Assistant Surgeon, die op weg daarheen door kwaad weer op Timor belandde en vandaar te Soerabaja! 
met de door het Opperbestuur voorgeschreven reorganisatie van het boschwezen. Zijne standplaats was Samarang. Den 8 Aug. 1813 schrijft Raffles hem, dat hij is aangewezen to arrange and carry into effect the agreement entered into by Mr. Crawfurd with the landholder of Bysookie and Panarookan and also to adjust the amount to be refunded to the family of the late proprietor of Probol.; verder dat de Regeering van plan is, om in the Eastern Districts de landrente in te voeren en $\mathrm{H}$. te gebruiken as one of the Commissioners for effecting this object; daar nu de gewezen Chineesche landen deel uitmaken of the districts to be settled by you, kan hij alvast onderzoekingen doen. Eene benoeming tot Commissaris voor de invoering der landrente was dit derhalve niet; doch in de instructie van 5 Sept. 1813 voor Adams als zoodanig, wordt vermeld, dat Hopkins is aangewezen als Commissioner for settling the more Eastern districts; gewaagd wordt van the experience which this gentleman possesses in the revenue arrangements of Bengal added to his very superior talents and general ability. De grenzen van hun beider competentie blijken uit Hopkins' ongedateerde instructie: Adams zou den aanslag verrichten in the districts west of Probol. or Passourowang as far as Sidayo inclusive, en $\mathrm{H}$. in the districts east of Bangil; aan Hope schrijft Raffles 7 Sept. 1813, dat deze laatste opdracht betreft the districts east of Passeroang (Banjoewangi was er onder begrepen); H. kreeg 500 Roep. p. m. tafelgeld. Den 17 Sept. 1813 neemt hij van Cotes over the charge of the districts of Probolingo, Besuki, Panaroekan and Poegar; hij teekent voortaan dan ook als zijnde in civil charge. Aangaande Pasoeroean schrijft $\mathrm{H}$. den 8 Nov. 1813, diep gekrenkt te zijn, dat Jourdan aldaar met den aanslag is belast; Raffles antwoordt 14 Nov., dat deze residentie wat den aanslag der landrente aangaat onder $\mathrm{H}$. staat en dat Jourdan is gelast naar diens aanwijzingen te luisteren. Hopkins overleed echter reeds 29 Dec. 1813 te Probol., nog vóórdat de contracten met de rechthebbenden der voormalige Chineesche landen waren geteekend. $\mathrm{Na}$ zijn dood werd hem bij Proc. 8 Maart 1814 een salaris van 1.200 Java Roep. toegekend als waarnemend Resident. De advertentie van den verkoop zijner nalatenschap staat in Gaz. 29 Jan. 1814; hij bezat o.a. a large collection of books in Greek, Latin, French and English, well selected and many of them rare. Hij geeft in zijne stukken den indruk van eene flinke en knappe persoonlijkheid, soms wat doctrinair. Zijn grafschrift staat bij Campbell I, 503. Een handschrift van hem in the collection of the Earl of Minto (over den 
notemuskaatboom) wordt vermeld bij Crawfurd, History I, 510. Over Raffles' hooge achting voor hem spreekt de Widow bl. 219.

Horsficld (Dr. Thomas) van Bethlehem in Pennsylvanië, kwam in Oct. 1801 op Java en werd voortdurend, tot aan de verovering van het eiland, door de opeenvolgende Regeeringen ondersteund bij zijne wetenschappelijke, in hoofdzaak botanische, studiën; zie Priangan IV, p. 561. Zelf was H. erkentelijk genoeg voor deze hulp; Raffles vond echter goed, die volstrekt te negeeren en in zijne History I, 34 aan te teekenen, dat $H$. ,, for the last seven years” de natuurlijke historie van Java had bestudeerd, dus sedert 1810 ! Echter deed reeds het Voorberigt van Deel VII der Verh. Bat. Gen. zien (doch in het Nederlandsch), hoeveel H. aan dat Genootschap en de Nederl. Regeering had te danken. In zijn Discourse in datzelfde deel maakt Raffles er ter loops melding van; hij bevond zich toen onder Hollanders, en moest dus nog zekere convenances in acht nemen. Zeker vond Horsfield bij R. meer directe waardeering. Reeds bij diens eerste bezoek te Solo, waar H. woonde, schreef deze hem (25 Dec. 1811): „The information I have hitherto collected concerning the enquiries Your Honble has been pleased to propose concerning the climate, soil, mountains, rivers and productions of Java shall with all possible expedition be arranged and transmitted to Your Honble. The materials necessary for framing a general account of the climate, mountains, volcanoes, minerals and some of the chief rivers of the Island being in earlier readiness, I shall commence with them and make the other enquiries the subject of a future communication, while I shall premise a very concise account of the range I have taken thro' the Island and of the progress I have made in the investigation of the objects of my immediate research". Hem werd dus een werkprogram gegeven in verband met R.'s eigen onderzoekingen, en tevens (Proc. 4 Jan. 1812) een salaris van 500 \$, later 1.100 Java Roep., waaruit echter, naar Raffles 10 Oct. 1812 zegt, ook zijn personeel moest worden betaald. Den 5 Maart 1812 zendt hij aan R. a short account of the medical plants of Java, opgenomen in Verh. Bat. Gen. deel VIII. De opstellen, die H. plaatste in deze Verhandelingen, worden in R.'s boek nu en dan geciteerd; zie History I, p. 12 e.v. noot; p. 23 noot; 24 noot. Gedeeltelijk waren deze al onder het Nederl. bestuur geschreven. Ook met Lord Minto moet $\mathrm{H}$. hebben kennis gemaakt, want deze gedacht hem met eere in eene rede, den 30 Sept. 1812 gehouden in eene openbare zitting van het 
College of Fort William (Gaz. Extrao. 15 Dec. 1812). Den 1 Nov. 1812 vertrok $H$. naar Banka, op eene zending samen met Eales en Hanson (Widow p. 606); eerst 30 Juli 1813 kwam hij vandaar terug; een niet erg belangrijk rapport over die reis is in het archief ; zijne opnemingen zijn vermeld onder Robinson; bij eene beschikking van 7 Dec. 1813 kreeg hij eene extra toelage van 250 \$ p. m. voor den duur dier reis. De verdere vermeldingen van zijn persoon in archiefpapieren betreffen in den regel zendingen van naturaliën naar Europa, aan W. Ramsay (Raffles' patroon, den Secretaris der East India Comp.), aan Sir Joseph Banks, aan de Kew Gardens; ook eene van twee kisten levende planten aan den Botanical Garden te Calcutta en eene van planten en zaden naar Mauritius; deze laatste op verzoek van den Gouverneur aldaar, die zich bereid had verklaard andere planten naar Java te zenden (Proc. 6 April 1816). H. is derhalve langer op Java gebleven dan Raffles; in 1818 ging hij van hier naar dezen in Benkoelen en begeleidde hem naar Paggeroejoeng (Widow p. $357 ; 629$; aldaar p. $602-632$ geeft $H$. verslag anno 1829 van zijne samenwerking met R.). Bij Raffles, History II, p. 33 e.v. vinden wij eene door $\mathrm{H}$. anno 1815 gemaakte beschrijving van bouwvallen in het Oosten der toenmalige Vorstenlanden (Kediri enz.); verschillende daarvan had hij ontdekt (ib. p. 38) during various botanical excursions which I made through this province; ib. p. 41 zijne beschrijving der bouwvallen van Singosari, die hij in 1815 bezocht; uit p. 45 blijkt, dat $\mathrm{H}$. ook schetsen van oudheden vervaardigde. Uit een archiefpapier zien wij, dat in Oct. 1813 zekere M. L. Doppert bij $H$. als teekenaar werkte, die nog in de Directory voor 1816 voorkomt als in the service of Dr. Horsfield; of dit de ,teekenaar uit het Samarangsch Marineschool" is, die hem in 1804 was toegevoegd (Voorberigt Verh. Bat. Gen. VII) blijkt niet. In eene aanteekening betreffende die school in 1805 leest men onder 30 Mei: „Zijn de jongelingen genaamt C. Coolen en Jan van Stralendorff weder met de Heer Horsfielt naar Souracarta en verder na den Oosthoek vertrokken ter afteekening van voorkomende planten, kruijden etc. en Braminische oudheden”. Elders zie ik, dat hij in 1806 eveneens over twee jongens uit die school beschikte. In het najaar van 1815 (Verh. Bat. Gen. VIII p. 26) onderzocht H. de streken O. en Z. van Solo. Uit Verh. Bat. Gen. ibid. p. $34 ; 43 ; 69$ blijkt, dat H. op zijne botanische excursies ook liggingen van bergtoppen bepaalde, de geologie bestudeerde en ethnologische en oudheidkundige aanteekeningen verzamelde. Over zijne bergbeklimmingen zie Priangan II, 410 noot 1. 
Olivier, Land- en Zeetogten I, 327 zegt, dat ook de Tangkoeban Prahoe nict door $\mathrm{H}$. is beklommen.

Bovendien vernemen wij uit Widow p. 614; 615 dat $\mathrm{H}$. in 1814 Raffles hielp bij het maken van eene kaart der Vorstenlanden en dat R. voor zijne kaart van Java de kaart gebruikte, welke H. had vervaardigd van het westerdeel der Vorstenlanden. H.'s teekeningen van oudheden in $\mathrm{O}$. Java werden in copie aan $\mathrm{R}$. gegeven, ibid. p. $622 ; 623 ; 624$. Speciaal na R.'s vertrek van Java ging $H$. zijne aanteekeningen van allerlei aard omtrent de Vorstenhoven en de Vorstenlanden completeeren en zijne verzameling teekeningen uitwerken, zoowel die op het gebied der natuurlijke historie als ,views, maps and plans" (dus vermoedelijk met het oog op de uitgave van R.'s boek); zie Widow p. 626. Wanneer wij echter (ibid.) lezen, dat H. nog in het laatst van 1817 Prambanan, Boroboedoer en Tjandi Sewoe bezocht, kan dit niet met R.'s boek, dat toen reeds verschenen was, in verband staan. We zien dan ook (zie onder $V a n$ Naerssen), dat $\mathrm{H}$. al vóór de verovering van Java schetsen had laten maken van Javaansche ethnologica, dus denkelijk voor eigen gebruik. Toen Van Sevenhoven in 1812 Solo bezocht, vond hij H. bezig aan ,,een kaart, waarop hij aantoonde de aart der gronden en voortbrengzelen van dezelve op het ijland Java; hij had daarbij ook tevens het caracter, zeden en gewoontens der Javanen gadeslagen", zoodat de bezoeker onderstelde dat hij ,,behalve de natuurlijke historie ook eene algemeene beschrijving van Java zal leveren, die zeker zeer belangrijk zal wezen, daar hij de Javaansche taal volkomen magtig is". In de Bat. Cour. einde 1818 adverteert Horsfield, dat hij Java gaat verlaten.

Crawfurd (Dictionary p. 428) gewaagt van H. als ,my old and esteemed friend".

Hubbard (A. H.), geb. te Norwich in Connecticut, oud 20 jaar, komt 26 Dec. 1811 van Calcutta met 5 native printers te Bat. Werd drukker van de Java Gov. Gaz. Blijkens Proc. 5 Jan. 1813 was zijn salaris $400 \$$.

Hunt (John; hij teekent zich ook Ino Hunt), geb. in India ,place of birth unknown" zooals hij zelf zegt, is een dier louche personen, waarvan Raffles zich wel bediende. Was in 1810 op de Soeloe Eilanden. Hij komt per Comp.'s kruiser den 25 Aug. 1812 uit Bengalen te Bat. en stelt zich reeds 23 Sept. op den voorgrond, 
door bij eene meeting op het Stadhuis eene lange en warme lofrede te houden op het Eng. bestuur over Java, welke rede in extenso in de Gaz. van 3 Oct. 1812 werd opgenomen. Den 31 Dec. van dat jaar teekent hij een bewijs van ontvangst van 8 slaven muzikanten met allerlei muziekinstrumenten, ten koste van het Gouv. hem geleverd voor 5.000 \$. Daar Raffles reeds een muziekcorps had, zou het kunnen zijn, dat dit voor zijne expeditie bestemd was. In April 1813 treffen we hem als Commercial Agent der Regeer. te P'ontianak, alwaar hij den 14 Maart was aangekomen; hij dreef er handel in Comps. goederen met den Sultan; den 21 Mei 1813 schrijft de Regeer. hem: „On the return of the detachment sent against Sambas you will remain at Pontiana in your capacity as Commercial Agent". Den 29 Oct. 1813 kwam hij vandaar te Bat. terug, en den 11 Dec. 1813 vandaar te Samarang, alwaar Raffles den 26 Dec. 1813 last geeft, dat H. voor 20.000 \$ aan waren uit de Gouv. pakhuizen mag uitkiezen voor een commercial adventure naar China en voor nog $10.000 \$$ mag inkoopen. Uit een schrijven van denzelfden dag blijkt, dat hiermee beoogd werd eene aanknooping met de Soeloe Eilanden, zoodat hij thans benoemd wordt tot Resident at Sooloo op zijn tegenwoordig salaris als agent te Pontianak en met the same indulgence with regard to trade, onder betuiging van de tevredenheid der Regeer. over zijne verrichtingen aldaar. Het een en ander werd bevestigd Proc. 17 Jan. 1814. Den 7 Jan. 1814 machtigt de Regeer. den Accountant tot de uitbetaling van 20.000 \$ aan Hunt voor die reis. Bij acte Piepers 15 Jan. 1814 no. 2289 sloot hij een contract van compagnieschap met Van Gesseler te Lintelo te Bat. voor den tijd dat hij Resident op Soeloe zou blijven; Lintelo zou hem handelsartikelen toezenden en Hunt zou die verkoopen en andere, geschikt voor China, inkoopen en naar Canton zenden. Hij vertrok van Samar. 23 Jan. en van Soerab. 29 Jan. 1814. Deze reis (er waren ook soldaten aan boord en het heette dat men den zeeroof wilde bestrijden) was eene mislukking; al vóór Sept. 1814 verliet hij Soeloe; in Jan. 1815 zat hij te Manila zonder kans te zien tot eene expeditie naar Canton; den 30 Maart 1815 kwam hij met zijne bijna onaangebroken lading en zijn detachement inl. soldaten over Broenei (waar hij werd afgewezen) en Pontianak te Bat. terug. Het Commercial Committee bleek zeer slecht te spreken over Hunt's aankoop van paarlen op de Soeloe eilanden. Crawfurd, Dictionary p. 407 e.v. (s.v. Soolo) zegt, dat Hunt's rapport over deze eilanden, door Raffles gedrukt in Verh. Bat. Gen. „, for 1812”, purely fabulous en onzin is. 
Proc. 12 Sept. 1815 wordt hij niettemin benoemd tot Assistant to the Resident van Pekalongan; eerst 1 Nov. nam hij zijn werk over van Murray. Als zoodanig maakt hij den indruk van een avonturier, die met alle kracht elken maatregel van Raffles, zooals de circulaire van 7 Nov. 1815, steunde. Bij schrijven van Raffles dd. 19 Jan. 1816 werd toegestaan een verzoek van Hunt om te huren a tract of uncultivated land, including the coffee gardens at Banjoewangi; hij kan nu daarheen gaan for the purpose of making your selection of the lands accordingly, en Murray wordt weder tot zijn opvolger te Pekal. benoemd. Proc. 2 Febr. 1816 heet het, dat die landen zouden dienen tot indigoteelt. Zie nog Van der Kemp in Bijdr. 1897 p. 20. In 1827 heeft hij eene zaak te Soerabaja in compagnieschap met H. R. Spencer. In 1829 woonde hij te Soerabaja en kreeg toen het land Soekowati (district Wirosobo West) in erfpacht.

Den 17 Juli 1835 overlijdt te Pasoeroean Mr. John Hunt Senior. Dit is de persoon, die in erfpacht had de landen Bandarjejer (sic) en Soekawati. Zijn zoon J. P. Hunt, geb. op de kust van Cormandel, woont 1841 te Soerabaja.

Hunter (G.), Lieutenant, werd gewond bij de bestorming van Meester Cornelis; is Dec. 1811 bij Raffles te Samarang; wordt gewond bij eene kruitontploffing bij de beschieting van Djokja (Conquest p. 68; 181); onderscheidt zich bij de bestorming van den kraton (ib. p. 194). Vertrekt 15 Dec. 1811 van Samarang naar Djokja met Pangeran Noto Koesoemo, om eene boodschap aan den Sultan over te brengen (Van Deventer p. 312). Bij Gen. Orders van 13 Febr. 1812 werd hij benoemd tot commandant der Djajang Sekars in de Samarang Division, als hoedanig hij met ingang van 4 Aug. 1812 werd vervangen (Gen. Orders 22 Oct. 1812). Hij werd toen commandant der lijfwacht van den Soenan en Assistant to the Resident te Solo en als zoodanig den 28 Aug. 1812 belast met de overname van Grobogan op 200 \$ per maand, doch reeds bij Gen. Orders van 7 Nov. 1812 op zijn verzoek ontheven en naar Batavia overgeplaatst om adjudant van Gillespie te worden. Bij Gen. Orders van 22 Jan. 1813 kreeg hij verlof naar Europa, maar ook daar kon hij het niet lang harden, want bij een schrijven van 28 Dec. 1813 gaf het Court of Directors verlof tot zijn terugkeer naar Java. Wij bespeuren echter niet, dat hij er weer kwam. Uit de krant zien wij, dat hij bij de races te Salatiga in Oct. 1812 de meeste paarden liet draven; misschien had dit hem genekt. 
Hunter $(D r . W$.$) nam als Superintending Surgeon deel aan de$ expeditie tegen Java; na de verovering wordt hij Proc. 1 Nov. 1811 als zoodanig bevestigd op 800 \$; gaat weldra naar Samarang tot organisatie van den medischen dienst, Proc. 23 Nov. 1811, en bleef tot eind Febr. op reis over het eiland; zijn rapport dd. 16 April 1812, opgesteld tijdens de expeditie naar Palembang, staat in Proc. 22 Juli 1812 . Hij teekent 17 Mei 1812 het contract met den nieuwen Sultan (Conquest p. 172). Komt 30 Juni 1812 van Muntok te Bat. en overlijdt te Weltevreden 16 Dec. 1812.

In de Gaz. van 19 Dec. 1812 wijdde Raffles hem eenige regelen, waarin ook werd gesproken van zijne letterkundige talenten; veel warmer prees Lord Minto (Gazette Extraord. 15 Dec. 1812) zijne groote verdiensten ook op het gebied der Oostersche talen en als gewezen Secretaris van den College Council te Calcutta, d.i. van het College of Fort William tot wetenschappelijke opleiding van ambtenaren, waaraan hij leeraar was geweest (Carey II, 24). Bij zijn dood was hij Secretaris van het Batav. Gen. en Superintendent der pers op 250 \$; hij had zelf eene drukpers op Java gebracht en die aan het Gouv. verkocht voor 30.000 Sicca Roep. (Proc. 2 April 1814), zeker geene kwade speculatie. De nieuwe redacteur der Gaz. wijdde hem eene herinnering in het nummer van 2 Jan. 1813; zie verder de nummers van 17 Juli en 7 Aug. 1813. Raffles (History I, 132) vermeldt een geschrift van hem over pepercultuur. Hij schijnt een zeer beminnelijk mensch te zijn geweest. Hij liet eene belangrijke bibliotheek na, Gaz. 12 Febr. 1814, waarvan sommige boeken nog in die van het Bat. Genootsch. berusten.

Ivatts $(W$.$) is Proc. 10$ Oct. 1812 Assistant and Examiner in the Secretary's office op $200 \$$. Wordt in Nov. 1813 vermeld als inspector of mines at Jeboos (Banka). Wordt Proc. 21 April 1815 benoemd tot Assistant to the Resident of Tagal ter vervanging van den overleden Ekeboom; vertrekt derwaarts 6 Mei 1815; wordt 12 Sept. 1815 benoemd tot Ass. Res. van Cheribon, eveneens ter vervanging van Ekeboom; neemt de residentie Tegal 29 April 1816 over van Homer en geeft haar 11 Mei 1816 over aan Forssteen.

Jacobson (Carel) werd bij Resolutie 22 April 1793 van bootsman bevorderd tot sous-lieutenant. Werd later Kapitein-Luitenant ter zee. Den 30 Dec. 1812 schrijft J. P. Hulft van Hoorn, Deputy Collector te Soerabaja, aan de Regeer. : „I have appointed Mr. Jacobson to act 
as Dep. Collector at Grissee”. In Febr. 1816 was hij dat nog, maar schijnt diezelfde maand door intrekking van het personeel aldaar buiten betrekking geraakt te zijn. In 1817 was hij havenmeester te Grissee en Kapitein-Luitenant der Koloniale Marine. Ver Huell (Herinneringen II, 6) noemt hem ,,een man, van zijne prilste jeugd af een beploeger der zilte velden"; hij woonde 1818 te Grissee en was getrouwd met eene Jav. vrouw (ibid. p. 56 ; 71). Eene heldendaad zijner dochter Cornelia anno 1817 is beschreven bij Van Rees, Vermeulen Krieger p. 147.

Jansen (L.) was 31 Dec. 1810 Drost te Banjoewangi, dus vermoedelijk ook nog bij de verovering.

Johnson (Jeremiah Martin), Major, onderscheidt zich bij de bestorming van Meester Cornelis (Conquest p. 19); wordt bij General Orders 29 Sept. 1811 benoemd tot Deputy Military Paymaster General en Proc. 23 Nov. 1811 tot Postmaster General te Weltevreden op $150 \$$. Onderscheidt zich bij de bestorming van den kraton te Djokja (Conquest p. 196) ; wanneer in de Gaz. van 22 Aug. 1812 te koop worden geboden ,16 pees grote brilante” van hem, zullen die wel uit den kraton afkomstig zijn geweest, als „loot”. Wordt Proc. 15 Oct. 1813 Vice-President der Weeskamer te Bat. Den 13 Dec. 1813 dateerde Raffles te Salatiga (waar Johnson toen denkelijk óók was, die 11 Dec. te Samar. was aangekomen) zijne benoeming tot Resident te Solo op 750 \$, an allowance of $100 \$$ en $2 \%$ commissie on the amount of the collection of revenue paid into the Treasury by you, and which commission is not to be less than 400 \$ per month, alles ongerekend zijn traktement als militair commandant aldaar, waartoe hij tegelijk werd benoemd. Bij schrijven van 14 Maart $1814 \mathrm{kreeg}$ hij voorts een tafel- en receptiegeld van 550 Java Roep. p.m. In Maart 1815 beliep zijn salaris als Resid. 2.500 Java Rupees, en zijn opvolger Van Haak zegt, dat hij ongerekend zijn tafelgeld nog zeer belangrijke sommen trok voor receptie en onthaal van het Hof en andere hooge gasten. Den $18 \mathrm{Dec}$. 1813 aanvaardde hij het bestuur, dat hij bleef voeren tot de teruggave. Uit erkentelijkheid voor zooveel goeds ontdekte hij, even vóór Raffles' bezoek in 1815, de tempelruïnen van Soekoe (aan de N.W. helling van den Lawoe) (Raffles, History II, 45 e.v.). Bij Crawfurd, History II, 194 de teekening eener voorstelling uit den tempel van Soekoe drawn by Colonel Johnson. In November 1815 vertoefde hij te Buitenzorg, van waar hij kort vóór 25 Nov. naar Solo vertrok 
(Widow p. 620), zoodat de Sepoy-samenzwering tijdens zijne afwezigheid werd ontdekt. Men kan van hem als Resident niet veel anders getuigen, dan dat hij aan Hart een knappen Assistant had, en dat hij Raffles behoorlijk naar de oogen wist te zien. Wederkeerig liet deze hem in zake de opiumpacht eene opmerkelijke en denkelijk niet onvoordeelige vrijheid van beweging.

Jongkind (J.), geb. te Middelburg 1768, komt op Java 1790 als kastmaker, was bij de verovering architect der civiele gebouwen te Bat. en werd als Superintendent of buildings, of the roads, bridges and canals in the city and Environs of Batavia and civil architect gehandhaafd; bij Proc. 28 Maart 1812 werd hem een salaris toegelegd van 300 \$, dat 10 Oct. 1812 wordt verhoogd tot $400 \$$. Den 8 Jan. 1814 wordt hij echter gedegradeerd tot Deputy Superintendent of public buildings and works, na plaats te hebben gemaakt voor K. Mackenzie als Superintendent (wiens bevoegdheden dezelfde waren als van den Civil Architect and Surveyor). Hij behield een salaris van 880 Java Roep. Hij overleed 25 Mei 1815.

Jourdan (H. G.), Lieutenant, vroeger, naar hij zelf 11 Mei 1813 schrijft, belast geweest met topographische opnemingen, werd gewond bij de bestorming van Meester Cornelis (Conquest p. 68); wordt Proc. 14 Febr. 1812 aangesteld tot First Assistant in the Lieut. Gov.'s office op 200 \$, terwijl wij Proc. 10 Oct. 1812 bespeuren, dat hij ook fungeerde als English Chaplain te Batavia (wegens de toeneming der English population zegt Raffles, dus hij preekte voor de gemeente!) op een salaris van niet minder dan 300 \$ (tweemaal zooveel als Professor Ross trok). Proc. 22 Jan. 1813 wordt hij met ingang van $1 \mathrm{Febr}$. benoemd tot Resident van Djapan en Wirosobo op $250 \$$ en $2 \%$ der revenue collections. Hij bleef echter eenige weken te Solo en aanvaardde zijne residentie eerst op 15 Maart 1813. Bij schrijven van 7 Sept. 1813 benoemde Raffles hem met ingang van 1 Oct. tot Resident van Pasoeroean en tevens tot Assistant van Resident Adams bij den aanslag der landrente, op 150 \$; deze laatste benoeming ging terstond in, doch in het laatst van September zat J. nog in zijne oude residentie, en reeds bij schrijven van 26 Oct. 1813 trok Raffles zijne toevoeging aan Adams weder in, onder bepaling dat J. geheel alléén den aanslag in Pasoeroean zou verrichten (hetgeen tot klachten van Hopkins leidde, zie aldaar). Bij schrijven van 24 Jan. 1814 ontslaat Raffles hem als

D1. 92. 
Resident, naar aanleiding der benoeming van Garnham (zie aldaar), doch handhaaft hem (of benoemt hem) tot Collector van Pasoeroean; doch toen Raffles den 24 Febr. daaraanvolgende aan Garnham schreef, dat Pasoeroean weer eene aparte residentie zou wezen, waarover G. geen gezag zou voeren, moet Jourdan als Resident zijn hersteld, wat hij vervolgens tot de teruggave is gebleven. Bij schrijven van 28 Dec. 1815 spoorde de Regeer. hem aan tot meer waakzaamheid en ijver. Hij was een der persoonlijke vrienden van Raffles, die een afscheidsadres tot hem richtten (Boulger p. 215).

Kam (Joscph), zendeling en Predikant. Den 23 Juni 1814 behandelt de Kerkeraad te Bat. een brief van Raffles, waarin, dat de onlangs alhier aangekomen Ds. Kam te Soerabaja zal staan, totdat hij naar Ambon kan vertrekken. Uit een rekest van hem uit Soerabaja, 16 Dec. 1814, bespeurt men, dat hij ternauwernood schrijven en spellen geleerd had (,Resiedent Crafort”, „hij heef”). Op Ambon schijnt hij echter goed werk te hebben gedaan (Olivier, Land- en Zeetogten II, 37). Overleed aldaar in 1833 en staat er nog heden in den reuk van heiligheid.

Karsseboom (P. C.), geb. te Batavia, komt 1804 als leerling op de Marineschool, is 1810 Luitenant bij de Jagers, is Jan. 1812 teekenaar 2e klas bij Cornelius; 1 Dec. 1812 is hij te Buitenzorg en dient eene rekening in voor 6 maanden salaris als draftsman op $60 \$$ (zie onder: Flikkenschild). Noemt zich Nov. 1813 „Adsistent op 't biereau tot het tekenen van kaarten van 't Gouvt." te Buitenz. Nog in Jan. 1815 is hij als teekenaar aldaar woonachtig, ja nog na Raffles' aftreden zendt hij hem 19 Maart 1816 eene kaart.

Keasberry (John Palmer), Major, geboren te Bath, kreeg, blijkens Gaz. 5 Dec. 1812, den 25 Aug. 1812 zes maanden verlof om van Madras naar Java te gaan; kwam hier echter eerst 14 Maart 1813 aan, en werd reeds Proc. 24 April 1813 met ingang van 1 Mei benoemd tot Resident van Tegal op 300 \$, welke residentie hij echter pas 23 Mei overnam van Zhaetzcky. Werd 24 Sept. 1813 te Madras bevorderd tot Lieut. Colonel, doch overleed als Resident van Tegal 29 April 1814. In Sept. 1813 was hij belast met den aanslag der landrente aldaar. Uit Proc. 17 Sept. 1813 blijkt, dat hij een long acquaintance with the Eastern Islands had benevens knowledge of their customs and language. 
Kilian (F. M.) van Kaap de Goede Hoop, trouwt 1799 Jacoba Jelleke van Bat., wed. C. F. Beumert; is bij de verovering Notaris binnen de stad Bat.; wordt 1 Nov. 1811 als zoodanig op verzoek ontslagen; werd hierop lid der Weeskamer; 11 April 1812 benoemd tot President van Boedelmeèsteren op 15 (sic) Sp. Ds. per maand; overlijdt 4 Dec. 1814.

Knight (G.), Captain, wordt gewond bij de bestorming van Meester Cornelis (Conquest p. 68). In Nov. 1811 tref ik hem te Banjoewangi aan als militair commandant en waarnemend Drost; hị was in laatstgemelde qualiteit benoemd door Raffles, zonder dat, naar het schijnt, aan de autoriteiten kennis daarvan was gegeven, zoodat, toen A. Loudon op last van Gibbs den 13 Dec. 1811 als Drost aldaar verscheen, dit tot een conflict leidde (ofschoon het salaris maar 80 \$ bedroeg); voorloopig werd Knight gehandhaafd en eerst bij schrijven der Regeer. van 17 April 1812 van zijne beide qualiteiten ontheven, in verband met geknoei met Balische slavenhandelaars; hij was door Hope reeds einde Maart geschorst en door Clark vervangen in afwachting van eene beschikking der Regeering.

Knops (J.), geb. te Heusden, in Mei 1784 op Java gekomen, was bij de verovering Oud-Resident van Japara; wordt bij besluit van 13 Jan. 1812 benoemd in de Commissie van onderzoek van den staat van Java op een daggeld van 12 \$ plus reiskosten; wordt Gaz. 4 April 1812 benoemd tot Administrator of Forests op 400 \$ (of dit dezelfde persoon is, blijft onzeker, doch het hooge traktement maakt het wel waarschijnlijk). Volgens Proc. 15 Sept. 1812 moest hij met Rothenbuhler alle mogelijke inlichtingen verschaffen aan de Commissie voor den landverkoop in Samarang; werd lid der Commissie voor die aangelegenheid 5 Nov. 1812; hij kocht toen het land Goemoelak, doch kreeg permissie om $1 / 4$ op Van Naerssen over te schrijven en $1 / 4$ op Van Lawick. Na de beëindiging der werkzaamheden van de Commissie van onderzoek, gelastte Raffles hem, den Resid. van Samarang Eales alle noodige inlichtingen te verstrekken voor de invoering van het landrentestelsel; hij roemde daarbij (Aug. 1813) zijne long experience and thorough knowledge of the detail of the districts. Hij overleed te Samarang 4 Mei 1814; het doodsbericht in de Gaz. roemt zijne beminnelijkheid.

Knops (J.), zoon van den vorige, 1801 leerling der Marineschool 
te Samarang, bij de verovering Luitenant, is Aug. 1812 onder Cornelius te Samar. werkzaam bij het copieeren van kaarten enz. als Opnemer der 1e klas; Juni 1813 noemt deze chef hem een ,extraordinaire good drawman, employed to draw the large chart of the district of Damak"; wordt Juli 1815 met Vodegel ter beschikking van Captain Baker te Solo gesteld op 160 Java Roep. p.m. De Resident te Solo klaagt echter 12 April 1816, dat K. has by no means fulfilled his engagement with me, for he engaged to travel with Captain Baker to make sketches and to complete them at Solo. En Baker zelf, 14 April: Having lately been up to Solo for the purpose of seeing what Mr. Knops had done in part of his agreement, I found scarcely 10 drawings etc. finished and nearly 100 as yet untouched, beside many plans etc. which he has yet to copy and many sketches yet to make (should I travel this year) in order to fulfil his agreement as a public servant. Daarop zond de Resid. van Samarang den weggeloopen $\mathrm{K}$. weer naar Solo om te voldoen aan certain engagements which he entered into some months ago.

Kool (G.), geb. te Bat. 1757, in dienst als leerling der Maleische taal 1771 , bij de verovering translateur voor het Maleisch, Waagmeester en lid van Schepenen; wordt benoemd tot Malay translator Gaz. 16 Mei 1812; zijn salaris was 150 \$, zijn klerkenpersoneel trok in totaal slechts 38 \$ p.m. Hij kende,,eenen zeldzamen schat van Maleische woorden" (heet het bij Roorda van Eysinga, Verschill. reizen II, 316) maar, daar hij niets geleerd had en gebrekkig Nederlandsch verstond, waren zijne vertalingen soms geheel verkeerd.

Krijgsman (C.F.), geb. op Java, wordt bij Resolutie van 7 Nov. 1797 van matroos bevorderd tot Translateur voor het Jav. te Soerabaja; is bij de verovering de eenige Gezworen translateur voor het Jav. te Samarang. Echter ziet men, dat hij bij vertalingen uit het Jav. zich soms moest laten helpen door den Regent Adimonggolo. Proc. 16 Mei 1812 blijkt, dat hij thans ontslag heeft gevraagd, omdat hij, teneinde zijne klerken te betalen, soms op zijn traktement moest toeleggen. Daar werd toen een mouw aan gepast (in Dec. 1813 wordt zijn salaris verhoogd tot $200 \$$ ), maar 6 Juli 1814 schrijft de Resid., dat hij opnieuw ontslag heeft gevraagd en in Dec. 1815 is hij geen translateur meer. Het kan wezen, dat K. nu en dain ook werkte voor de Residenten van Solo en Djokja (Bijdr. 1899 p. 324), maar de translateur te Solo in 1813,1814 en 1815 was 
H. Hornoff (denkelijk een zoon van J. C. W. Hornoff, stadschirurgijn te Samarang 1795) op het wonderlijk laag traktement van 80 Java Roep. p. m. De meer bekende Joh. W. Winter van Samarang, ,geswooren Translateur in de Javaanse taale, oud 30 jaaren, alhier te Souracarta beschijden”, verzoekt bij rekest dd. 25 Sept. 1811 op een salaris van 100 Rds. zilver te worden gecontinueerd ,ten einde beeter in staat te zijn zijne talrijke familie te kunnen onderhouden, en in dat geval steets op deeze plaats te moogen beschijden blijven". In 1815 woonde Winter nog steeds te Solo.

Kuhnau (J.C.) van Luneburg, gewezen officier, bij de verovering Scriba te Bangkalan, in Juli 1815 Assistent Res. op Bawean op 100 Java Roep.

Langewagen (P.) was einde 1810 Gezworen klerk bij den Secr.Gen. Veeckens; begon zijne werkzaamheden als Assistant onder Lawrence te Cheribon in Juni 1812. Naar het schijnt, nam zijn chef hem mee naar Samarang, waar wij hem 1 Nov. 1812 als Assistant to the Resident aantreffen. Toen Lawrence midden Oct. 1812 Samarang verliet en wegens ziekte naar Salatiga ging, gaf hij de residentie over aan Langewagen, die haar 23 Nov. 1812 overgaf aan Garnham. Proc. 17 Jan. 1814 heet hij Assistant in the police department and in charge of the Treasury op 150 \$; blijkens Proc. 30 Juni 1814 was hij tevens Collecteur van het collateraal. Toen Hardy's salaris als Assistant Resident te Samar. met 1 Maart 1815 ophield, werd L. met de waarneming zijner werkzaamheden belast. In Febr. 1816 werd hij geschorst wegens een kastekort; in Mei van dat jaar is hij waarnemend Fiscaal van den Circuit Judge der Samarang Division; bij een schrijven van 6 Juni 1816 werd de schorsing opgeheven verklaard. Wordt 1819 Ass. Res. voor de Financiën te Batavia, is dit nog 1822. Anno 1825 ontmoeten we hem als Resident van Bezoeki. Overlijdt als zoodanig 31 Jan. 1826. Zijne weduwe C. A. Palm hertrouwt eenige maanden later met H. J. Domis, Resident van Samarang.

Lazvick van Pabst (P. H. van), geb. te Geldermalsen in 1780 . Biographie van hem in Priangan I, 103 e.v. Bij de verovering van Java was hij Landdrost van Rembang en lid der Administratie van de Houtbosschen; hij weerde zich flink in het belang der verdediging; gaf daarna Rembang over aan Yule, doch bleef met diens 
goedvinden zijne ambten waarnemen; zijn salaris was slechts 200 \$. Bij besluit van 13 Jan. 1812 werd hij benoemd in de Commissie Mackenzie op 12 \$ per dag; hij bleef voorloopig zijn salaris trekken, ofschoon Hope reeds 29 Jan. 1812 Van der Werff tot provisioneel Landdrost van Rembang benoemde, aan wien Van L. den 1 Febr. 1812 Rembang overgaf. In Sept. 1812 fungeerde hij zelf weer als Landdrost; moest hij als lid der Commissie weer op reis, dan gaf hij zijn' gezag over aan den Scriba. Den 5 Nov. 1812 werd hij benoemd in de Commissie voor den landverkoop in de Preanger en Krawang en vertrok 17 Nov. 1812 daartoe van Rembang naar Buitenzorg. Den 11 Nov. 1812 wordt Hartilieff tot Resident benoemd; den 1 Dec. 1812 geeft Van L. de residentie over. Hij bleef nu ambteloos, totdat hij Proc. 17 Sept. 1813 werd benoemd tot Saltagent in the Samarang Division op 300 \$, ingaande 24 Aug. 1.1. Als zoodanig won hij den lof van zijn chef Macquoid. Bovendien aanvaardde hij 13 Feb. 1816 te Samarang de betrekking van provisional Assistant in the Revenue Dept. Proc. 11 Maart 1816 werd hij benoemd tot Assistant Res. aldaar in plaats van Macleod; Proc. 14 April 1816 heet het echter, dat hij aldaar, ter vervanging van Burney, Assistant Res. in the Revenue Dept. is; elders heet hij Assistant Collector of Revenue. Hij zelf schrijft, dat hij 15 Maart 1816 optrad als waarnemend Collector. Zijn salaris beliep als zoodanig 800 Java Roep., en als Zoutagent 600. Na de overname van Samarang door het Nederl. bestuur werd hij als overtollig afgedankt als Ass. Res., doch hij had toen al de benoeming tot waarnemend Resid. van Soerabaja in zijn zak. Den 20 April 1813 schrijft hij, dat hij geen Engelschen brief kan lezen; tot het laatst bleef zijne kennis dier taal bedroevend; het lijkt wel neger-engelsch wat hij schrijft. Raffles was hem echter niet ongenegen en verbeterde zijne geschokte financiën.

Lawrence (John Curson) was 1805 Writer te Penang op 120 \$ (Campbell I, 639) en in het begin van 1811 Malay translator aldaar (Widow p. 56). Wordt bij schrijven van 13 Mei 1812 benoemd tot Resident van Cheribon, als opvolger van den op 6 Mei overleden Waterloo; trad als zoodanig vóór $20 \mathrm{Mei}$ op. Wordt reeds bij schrijven van Raffles dd. 16 Juli 1812 benoemd tot Resident van Samarang op 600 \$; geeft den 22 Juli Cheribon (waarvan Tegal thans werd afgescheiden) over aan Raban en is 10 Aug. 1812 te Samarang in functie. Doch reeds 10 Oct. 1812 vroeg hij wegens 
ziekte ontslag en verlof to proceed to sea; hij ging toen naar Salatiga en gaf zijn werk over aan Langewagen; Proc. 4 Nov. werd het ontslag toegestaan; den 22 Nov. legt hij zijne betrekking neer. Hij komt nu 26 Nov. 1812 te Bat. Proc. 22 Jan. 1813 geeft Raffles kennis van L.'s benoeming tot Resident van Kedoe op 500 \$ p.m. en $2 \%$ van het bedrag der revenue collections, met ingang van 1 Febr. Begin Febr. 1813 vertoefde hij te Buitenz.; den 27 Febr. 1813 aanvaardde hij zijne nieuwe betrekking. Bij schrijven var $18 \mathrm{Mei}$ 1813 benoemde Raffles hem tevens tot Resident van Pekalongan, dat hij 5 Juni 1813 overnam van Hardy en alwaar hij dat jaar den aanslag der landrente verrichtte. Zijn opvolger De Salis verklaart de samenvoeging dezer residenties, welke zooals Raffles heel wel wist, niet aan elkaar grensden, uit een wensch om L.'s inkomsten te vermeerderen. Opmerkelijk is ook (evenals in zake Macquoid) dat deze uitbreiding van L.'s werkkring niet ter kennis van de Regeering werd gebracht. Hij bleef tot aan de teruggave Resident in deze beide gewesten. In Nov. 1814 stond hij bovendien Heyland met advies bij in den aanslag van Japara; in het najaar van 1815 maakte hij lid uit van eene commissie tot onderzoek van den staat der landrente in O. Java. Raffles roemt Proc. 22 Aug. 1815 zijne very great ability and exertions; evenzoo maakt Fendall Proc. 6 April 1816 hem een compliment. Wederkeerig vleide hij R.'s lust voor archeologie, door in Kedoe oudheden voor hem te verzamelen (History I, 56). Bij het onderzoek der knoeierijen van Heyland bleek, schrijft de Resident van Kedoe 23 Nov. 1816, dat L. ,de vermoedens tegen zich heeft van in die malversatie betrokken te zijn geweest". Deze opvolger zegt dat L.'s wettige inkomsten gemiddeld wel 2.400 Java Roep. per maand beliepen. Zie nog Van der Kemp, Herstel p. 253.

Leyden (Dr. John Casper), misschien van Hollandsche afkomst. Biographie van hem (uit de Edinburgh Annual Register) in Gaz. 25 Nov.; 16 Dec. 1815; 6, 13, 20, 27 Jan. 1816. Was een Schotsche boerenzoon, geboren 1775 , een wonderlijk genie; eerst opgeleid voor Predikant, daarna in 5 à 6 maanden klaargestoomd voor dokter om naar Indië te kunnen gaan en zich aan de studie van Oostersche talen te wijden; man van buitengewoon onafhankelijk karakter, ongehoord ruw van manieren, brutaal als de beul, niettemin dichter; gaf met Walter Scott uit The minstrelsy of the Scottish border; diens verzen op hem zie bij Boulger p. 133. Hij ging naar Indië in April 1803; was een beschermeling van Minto; Boulger zegt daaromtrent (p. 41): 
Lord M. was the chief of the great Elliot family of Teviotdale, which has played its part in border war and song for centuries. Leyden had helped to make the epics of the locality worldknown. He came from Teviotdale and might almost be termed a clansman of the Elliots". Bovendien was Minto zelf (zegt de biographie in de Gaz.), a man of letters and a poet. In Mei 1811 op de overvaart naar Java schrijft Minto (Minto in India p. 253): „Dr. Leyden's learning is stupendous and he is also a very universal scholar. His knowledge, extensive and minute as it is, is always in his pocket, at his fingers' ends and on the tip of his tongue" etc.; een verbazende praatvaar met een kraakstem. Ondanks zijne kennis van inlandsche talen kende hij echter den Inlander zelven zeer weinig, zooals wel blijkt uit zijn ijlhoofdig plan (Widow p. 25) van een Parlement van Maleische staten (waarover de sobere Crawfurd, Dictionary p. 216, de schouders ophaalt). In eene rede, na L.'s dood door Minto den 30 Sept. 1812 uitgesproken in het College of Fort William (Gaz. Extrao. 15 Dec. 1812), zwaait deze grooten lof toe aan L., die naar Java was meegegaan om de talen van den Archipel te bestudeeren; hij erkent, dat hij ook als Schot en nabuur veel voor $L$. voelde. Vooral verdient de aandacht, dat Raffles feitelijk zijne gansche carrière dankte aan L., die eenige maanden te Penang tot herstel van gezondheid bij hem was komen logeeren en de aandacht van Minto op hem vestigde (Widow p. $7 ; 14 ; 21 ; 25$ ). Zooals men weet, overleed L. reeds 27 Aug. 1811 (Widow p. 97 en 98); het grafschrift zegt: two days after the fall of Cornelis. Verzen op zijn overlijden Gaz. 29 Febr. en 10 Oct. 1812. Hij werd begraven op het kerkhof op T. Abang; links naast hem werd later Raffles' vrouw bijgezet; photo van het graf bij Boulger p. 184; zijne biographie zegt, dat zijn stoffelijk overschot werd honored with every respect by Lord Minto. Maar het is opmerkelijk dat Raffles, die letterlijk alles aan Leyden had te danken, zoo verregaand nonchalant te werk ging na diens dood, dat 's mans graf weldra zoowat vergeten was. Dit blijkt uit een bewaard briefje van Popkens aan R., gedateerd 1 Juli 1812, waarin hij meedeelt het graf te hebben ontdekt (,I have found out the grave”); hem is opgedragen een ,tomb” op te richten, waarop een opschrift zal worden aangebracht ,which your Excellency promised to send me". En ook toen bleef men nog maanden lang talmen, want 12 Sept. 1812 vraagt Popkens opnieuw om dat opschrift voor de tombe, die een Chinees zal maken. In de Jav. Cour. 18 Sept. 1847 wordt gezegd, dat deze tombe met vernietiging wordt bedreigd wegens ver- 
waarloozing door rechthebbenden. Misschien heeft toen een der Engelsche ingezetenen zich daarover ontfermd, maar ik zelf heb nooit eene ,tombe” aldaar gezien, wel twee steenen met opschriften, die waarschijnlijk aan de verdwenen tombe bevestigd zijn geweest.

In Verh. Bat. Gen. VII vindt men een door L. tijdens den overtocht naar Java geschreven opstel over Borneo. Raffles maakt in zijne History eventjes melding van hem (II, p. CLXI en wel in verband met eene door hem gerangschikte woordenlijst). Zeer warm sprak hij echter over zijn overleden vriend in zijne Discourse in Verh. Bat. Gen. VII. In 1821 schreef hij de inleiding voor Leyden's Malay Annals.

Leyden's les (Widow p. 26) aan Raffles: Make a great and mighty noise, is door dezen zijn leven lang trouw en met buitengewoon succes toegepast.

Lloyd (G. W. A.), Lieutenant, wordt Proc. 12 Sept. 1815 benoemd tot Assistant to the Resident of Cadoe, ter vervanging van Heyland; aanvaardt zijne werkzaamheden 25 Sept. 1815; wordt reeds Proc. 27 Oct. 1815 belast met de waarneming der betrekking van Ass. Res. te Cheribon ter vervanging van Farquharson; komt als zoodanig voor 6 Nov. 1815, doch is 12 Dec. 1815 alweer verdwenen. Hij lijkt haast wel een paid guest van zijn chefs geweest te zijn.

Loftie (B.), Assistant Surgeon, gehuwd met Raffles' zuster Leonora (geboren 1785, uitgekomen 1810), wordt Proc. 1 Nov. 1811 benoemd tot chef van het General Hospital te Soerabaja; den 10 Dec. 1811 benoemt Raffles, zelf te Soerab. zijnde, hem tot Superintending Surgeon of the Eastern Districts; den volgenden dag kent hij hem een salaris van $300 \$$ per maand toe from the date of your appointment as vaccinator by his Excellency Sir Samuel Auchmuty, Commander in chief of the expedition; bovendien zijne reiskosten. Den 28 Febr. 1812 klaagt de Regeering dat hij, als belast met the vaccinating department, nog heel geen rapport heeft ingediend. Elders blijkt echter, dat Hunter zijne rapporten had. Den 12 Maart overlijdt hij te Samarang. De weduwe hertrouwde zeer spoedig met Campbell Brown (zie aldaar).

Loudon (Alexander), vader van den G.-G. van dien naam, geb. in Schotland, kwam, blijkens Proc. 16 Nov. 1811, als passagier (sic) per H. M. Hussar uit Engeland with the view of being advanced to 
a purser in the Navy; hij was echter a very attentive and prudent young man, zoodat, toen de Commandant der Hussar in Oct. 1811 Banjoewangi bezette, onze Schot zijn victualiemeesterschap in spe er aangaf en er zich als Resident liet plaatsen; de Commandant gaf 10 Oct. 1811 van deze gebeurtenis kennis aan Minto met eene aanbeveling van L.; in Nov. vinden we hem er als acting civil Resident; hij schijnt echter spoedig weggegaan, doch er opnieuw door Gibbs geplaatst te zijn, toen Raffles reeds Knight had benoemd, met wien nu een conflict ontstond. Blijkbaar had L. een machtigen steun, want 14 Febr. 1812 schrijft Raffles aan Hope: „With respect to Mr. Loudon you are authorized to employ his services in any way that may be found useful, reporting the same to Govt.". Hij werkte vervolgens op Hope's kantoor als Assistant op 150 \$; Proc. 16 Mei 1812 wordt goedgekeurd dat hij tijdens Boggie's ziekte dezen vervangt; later in 1812 is hij belast met de kas van het residentiekantoor; Proc. 13 Juli 1813 wordt goedgekeurd, dat hij gedurende Eckford's ziekte fungeert als Secretaris van Hope; 11 Oct. 1813 neemt hij het Revenue Department over van Boggie en geeft dit 20 Nov. 1813 over aan Davies; den 2 Mei 1814 treedt hij te Samarang opnieuw op als Acting Collector of Customs, ter vervanging van Davies; den 7 Nov. bovendien als Acting Deputy Resident ter vervanging van Hardy; den 9 Nov. nog extra als Master Attendant, terwijl hij van af 1 Aug. 1814 tot 16 Nov. 1814 daarenboven nog archivaris van den Civil Commissioner was op $300 \$$. Of deze cumulatie van ambten uitsluitend wijst op favoritisme, is mij niet bekend; de stukken van zijne hand in het archief zijn niet van dien aard, dat zij een oordeel omtrent zijne bekwaamheid mogelijk maken. Zijne eerste vaste benoeming is bij Proc. 6 Dec. 1814 tot Deputy Collector of Customs te Samar., wat hij bleef tot aan de overname van Samarang door het Nederl. bestuur; onderwijl was hij acting Master Attendant tot 17 Aug. 1815, en ook soms weer acting Deputy Resident. Hij trouwde den 10 April 1815 te Samarang met eene juffrouw Susanna Gaspardina Valck. Is later administrateur der T jiasem- en Pamanoekanlanden geweest (met woonplaats te Tenggeragoeng) tot einde 1828 (Camphell I, 650), toen zijne vrouw den 30 Nov. overleid, oud 28 jaar, nalatend zes kinderen. Had daarna eene suikerfabriek in Pekalongan (ib. II, 928); kocht 1835 de suikerfabriek Poegoe in Kendal (ib. 929). De steun, dien hij thans achter den rug had, was Baud, die nog steeds met zijn vriend Alexander Loudon in correspondentie stond (Mijer's Baud p. 509 ; 696). Hij overleed te Rotterdam 12 Oct. 1839 , oud 50 
jaar. De familienaam van zijn vroegeren patroon Hope is als persoonsnaam in zijn geslacht gebleven.

Lunel (W.F.) uit Cochin, komt op Java 12 Juli 1812 als stuurman, wordt 22 Maart 1814 benoemd tot Assistant van Resid. Macquoid in Soemedang, Soekapoera en Limbangan and coffee overseer at Limbangan.

Macartney (J.), Lieutenant 4th Volunteer Battalion, wordt bij Gen. Orders van 28 Juli 1812 geplaatst bij het Javanese corps; wordt Proc. 23 Dec. 1812 belast met the civil duties at Banjoewangie, ter vervanging van Clark; neemt 21 Jan. 1813 die residentie over van Joseph Mackenzie; overlijdt na eene langdurige ziekte aldaar 19 Aug. 1813.

Macgregor (R. B.), geb. in Bengalen, op Java gekomen 2 Febr. 1813, wordt 28 Mei 1813 angesteld tot Deputy Master Attendant and Storekeeper at Anjier op 200 \$. Verdient vermelding, omdat hij (ongerekend Dupuy, die een halve Hollander was, en Francis, een halfbloed) de eenige Engelschman is geweest, die na de teruggave is blijven doordienen onder het Ned. bestuur.

Mackenzie (Colin) van Stornoway, county Ross, Scotland, Lieutenant Colonel Madras Engineers, volgens Boulger (p. 159) a highly distinguished officer, with whom Raffles maintained cordial relations. When he conducted the survey of Mysore, under Lord William Bentinck's orders, Leyden served with the commission as medical officer. Bizonderheden omtrent hem geeft de in 1828 te Calcutta door H. H. Wilson in het licht gegeven Descriptive Catalogue van M.'s verzamelingen van handschriften enz., waarmee hij in 1796 was aangevangen en waarvoor langzamerhand een heele staf van inl. medewerkers was gevormd; hij was uitgegaan van geographische onderzoekingen en had later ook statistiek en geschiedenis in zijn program opgenomen; zijne persoonlijke onkosten voor dezen langjarigen arbeid bedroegen gaandeweg meer dan 100.000 Ropijen. In de Gaz. Extrao. 15 Dec. 1812 wordt hij door Minto buitengewoon geprezen wegens zijne signal and extraordinary powers of collecting, preserving and digesting useful and interesting information in every branch of knowledge, but more particularly in researches connected with the history, antiquities, religion, manners and occupations, zooals was gebleken in the Deccan and Carnatic. De Gaz. 3 Oct. 1812 zegt, dat 
zijne researches into the history, antiquities and statistics of the Peninsula of India are well known and have received an honorable testimony from the authorities in Europe. In 1811 was hij Surveyor General on the Madras establishment. Bij de expeditie tegen Java fungeerde hij als chef van het Engineer Department (Widow p. 39); al vóór de landing der Eng. kreeg hij eene opdracht (Conquest p. 14) om Soerabaja te verkennen; daarna onderzocht hij de landingsplaats te Tjilintjing (waarbij eenigen der zijnen gevangen werden genomen en hij zich enkel kon redden door zijn lange beenen; Collet p. 430), en voegde zich op 2 Aug. 1811 met zijne, ,ships” bij de vloot, die bij de Boompjes Eil. lag (Conquest p. 15). Van zijne verdere verrichtingen bij de verovering vernemen wij niet. Alleen bespeuren wij, dat hij in Oct. 1811 te Soerabaja was en reeds toen een rapport indiende over de aldaar aangetroffen kaarten. Proc. 1 Nov. 1811 lezen wij, dat hem is gevraagd to give his assistance to the Commission (Van Boeckholtz en Lippe) in the arrangement of the plans, charts and military records, welke door die Commissie waren bijeengebracht en gesorteerd. Hiermee kreeg dus M. al dadelijk toegang tot alle stukken en kaarten, die hem konden interesseeren, en daar reeds Proc. 18 Nov. 1812 de onder toezicht van Muntinghe en Cranssen vervaardigde inventaris der archieven werd overgelegd, zal de keuze daaruit niet te moeilijk zijn geweest. Reeds 24 Nov. 1811 had Raffles eene circulaire aan de Landdrosten gericht, om M. op zijne a.s. reis in alle opzichten behulpzaam te zijn en hem toegang tot de archieven te verleenen; vervolgens den 28 Nov. aan dezelfden en verschillende particulieren eene circulaire met vraagpunten van verschillenden aard, verband houdend met de statistiek, economie, ethnologie enz. van Java, en toen deze tijd van bezinken had gehad, eene nieuwe circulaire order van 29 Dec. 1811 om M. alle hulp te bewijzen bij de nasporingen van dien aard, die hij thans op eene rondreis zou ondernemen. In die dagen bevond M. zich in de Vorstenlanden; den 24 Dec. ging hij met Muntinghe en Phillips naar Djokja om Raffles' ontvangst aldaar te regelen (Van Deventer p. 313). Den 13 Jan. 1812 werd vervolgens de Commissie benoemd ter voorbereiding eener verbeterde belastingregeling, waarvan M. voorzitter was (leden Rothenbuhler, J. Knops en P. H. van Lawick van Pabst) op een daggeld van 12 \$; den 15 Jan. 1812 ging een last aan de Residenten, om deze Commissie in alle opzichten voor te lichten en te helpen. Over de nieuwe, door deze Commissie rondgezonden vraagpunten en hare verdere werkzaamheden, behoeven wij alhier 
niet te spreken. Wij noteeren enkel, dat blijkens zijn gedrukt journaal (Verh. Bat. Gen. VII, no. IX) Mackenzie den 19 Jan. 1812 te Prambanan aankwam (vanuit Solo) samen met Knops (den ouden denkelijk) en een teekenaar, en aldaar de Hindoe-monumenten beschreef en gedeeltelijk in beeld liet brengen. Blijkens eene bewaarde rekening vergezelde de teekenaar Wardenaar van 14 Febr. tot 14 April 1812 onzen M. bij eene reis over het eiland for the purpose of taking certain sketches. Uit een aan Hope gerichten brief blijkt voorts, dat M. den 18 Febr. 1812 van Soerabaja naar Banjoewangi vertrok, ,purposing to visit the island of Bally”. Uit dien tijd is wellicht ook wat Raffles (Hist. I, 180) vermeldt over Grissee volgens M.'s journaal. Dat hij naar Bali is gegaan, is onwaarschijnlijk. Den 1 Juni 1812 diende hij te Samarang een rapport in aangaande de kaarten, welke hij in O. Java had aangetroffen (opgenomen in Proc. 15 Aug. 1812), waaruit blijkt dat hij reeds 13 Oct. 1811 aan Minto een plan had voorgelegd betreffende de opneming van Java, hetwelk 18 Oct. was goedgekeurd; hij noteert dat hij geene kaarten heeft meegenomen, doch alleen copieën heeft laten vervaardigen of a few that I conceived useful in India; in de archieven had hij geen memoirs or papers relating to the military defence or history of the country aangetroffen, doch van particulieren had hij erlangd several documents illustrative of the history of the country. Den 10 Juni 1812 schrijft hij uit Samarang aan Raffles : hij heeft zijn Dutch translator en zijn English and French translator overgedaan aan het Committee waarvan hij President is; Mr. Lucius Rawdon Burke, who has been employed by me in investigations on this Island previous to the appointment of the Committee, but which are useful to its objects, in translating from the French and by means of that language from the Dutch, Malays and Javanese (dus deze laatste vertalingen werden door anderen, natuurlijk Hollanders, gemaakt) verdient zeker een salaris van af 1 Nov. 1811; diens habits in statistic investigations with me in India have qualified him to be peculiarly useful on this service; ook Wardenaar (zie aldaar) verdient eene Ielooning; having had no opportunity of engaging a Javanese writer since the late orders of Govt. allowing thereof, and the short time of my stay in Java rendering it unnecessary to engage one, behoort hij vergoeding te ontvangen for occasional interpreters and copyists in that language; having left two assistant surveyors and six lascars (a part of the public establishment sent with me from Madras) at Batavia and Buitenzorg in November last, either in charge 
of public instruments and property, employed in surveying about Buitenzorg etc., or copying plans for the public service, and who have expressed much solicitude for returning to India and in consequence absolutely lately declined to survey the road form Buitenz. to Cheribon etc., zullen die menschen weldra moeten worden teruggezonden. Wij zien dan ook, dat in Aug. 1812 de beide Assistant Surveyors John Faulkner en John Malcolm met twee lascars teruggaan. Mackenzie zelf, die in Juni dus ook spoedig meende te vertrekken, onderscheidde zich diezelfde maand bij de verovering van den kraton van Djokja (Conquest p. 199; wordt daarvoor bedankt door den Commander in Chief in Bengalen, Gaz. 13 Febr. 1813). Wat nog krasser is, hij trad kort na de vergadering van het Batav. Genootschap, die op 14 Oct. 1812 werd gehouden ten huize van den Stadsapotheker J. G. D. Paschen (een Mecklenburger uit Schwerin), den 18 Nov. 1812 te Bat. in het huwelijk met diens minderjarige pupil, de jongejuffrouw Petronella Jacomina Bartels van Trinconomale; curieus uitvoerige huwelijksche voorwaarden bij acte Drost 17 Nov. 1812 no. 2411; er was geen gemeenschap van goederen, doch M. verbond zich, haar eene lijfrente van 300 pond na zijn overlijden te verzekeren, de vermaarde three hundred a year dead or alive, waarop Engelsche meisjes in Britsch-Indië destijds met ambtenaren trouwden (zie Carey I, 98). Dit nadat hij (Gaz. 3 Oct. 1812) was teruggekeerd van een tour through the Eastern districts of Java, waarop hij had obtained a variety of valuable and curious information and made large collections of antiquities, manuscripts and inscriptions. Wanneer Raffles den 12 Jan. 1813 schrijft (Widow p. 206) : Colonel M. has visited Majapahit and every part of the Island, kan dit eerder op de reis samen met Wardenaar slaan dan op deze. Wat zijne verzamelingen betreft, ook Van Sevenhoven schrijft in zijn reisverhaal van 1812, dat M. ,een groote versameling van Javasche handschriften heeft gemaakt". Van zijne verdere werkzaamheden vernemen wij niet veel meer. Alleen (Proc. 23 Juni 1813), dat hij wegens voortdurende ziekte van zijn personeel van den weg van Jacatra in Aug. 1812 was verhuisd naar Goenoengsari, en dat onder dit personeel vele mutaties hadden plaats gehad. Raffles spreekt (Discourse p. 15 in Verh. Bat. Gen. VII) den 24 April 1813 van M. als hebbende bezocht almost every part of the Island; hij heeft facsimiles vervaardigd (op geolied papier) van several inscriptions found in different parts of Java, die hij in Britsch-Indië hoopt te ontcijferen. Den 13 Juli 1813 vroeg hij passage naar Bengalen voor zichzelf, zijn gezin 
en bedienden en Mr. L. R. Burke, writer and translator, and John Newman, draftsman, both employed by me on the service in Java, who accompanied me from India. Hij vertrok 18 Juli 1813 en bracht aan Lord Minto het adres over der Ned. ingezetenen van Bat. (Gaz. 20 Nov. 1813); zijne vendutie had 30 Juli plaats. Bij Gen. Orders van 15 Juli 1813 (opgenomen in de Gaz. 17 Juli) had Raffles hem hoogen lof toegezwaaid; beter dan elders vermeldt hij hier de vroeger onder het Ned. bestuur verrichte onderzoekingen en opnemingen, en de belemmering, die deze hadden ondervonden door de ongelukkige tijdsomstandigheden, onder aanteekening dat het vroegere topographische onderzoek will be continued partly on the same plan. Het Gouvernement te Calcutta hield M. eenige maanden aldaar aan ter completeering van his report on the result of his enquiries op Java. Uit Wilson (u.s. I, pag. XIV) blijkt, dat M. ,detailed reports” had ingediend bij ,the Governments of India”, welke echter verloren schijnen. M.'s onderzoekingen waren evenwel niet spoedig voltooid, want 6 Dec. 1814 schreef hij nog uit Calcutta aan Cornelius: „I expected some time ago to have heard from you with some of the drawings you were pleased to promise me, the views of Brambana and some plans with specimens of the curious woods of the Island. You would oblige me by sending them to care of Major Campbell.... The expense attending them will be cheerfully remitted.... I also wish much for a good general map of the East Hook of Java and a copy of the map of Sagara Nooka which I found I omitted to get from Java. I should like to know how you ascertain the positions of the villages named in your maps.

Memorandum: MS. and drawings wanted from Major Cornelius to be forwarded to Lieut. Coll. Mackenzie, Calcutta, care of Messrs. Shrapnell and Co, Batavia, or Major Campbell, Comm. Genl.

1. View of the antiquities at Brambana and the officers and people as employed there, which I saw at Samarang.

2. Plan of the country about Brambana exhibiting the situation of the different buildings. I have already got from Major Cornelius the plan of the temple at Brambana.

3. View or drawings of the stone pillar and monument at Toogoo near Samarang etc.

4. View of the Dassar and of the Sandy Sea near it in the East Hook of Java.

5. Map of Saagara Nooka and also a general map of the whole East Hook of Java. 
6. Copies or fascimiles of any other (sic) inscriptions.

7. Any MS. in Dutch or Javanese of the history of Java or the islands bordering on it, particularly a history in which it was said some account was given of the ancient settlement of colonies from Siam or Pegu at Cheribon and the East of Java".

Cornelius zond 20 Febr. 1815 eene copie van dit schrijven aan de Regeer.; als deze de toezending van het gevraagde goedkeurt, I then will be enabled to comply with Col. M.'s request, principally by making a begin in surveying the East Hook of Java, of which no geographical chart has untill now been made, the more as some of my late engineer officers that live here and have no employ, are inclined to perform these works, to find a subsistence for themselves and their wives and children. Waarop Raffles den 7 Maart de weinig aanmoedigende marginale beschikking gaf, dat het uitsluitend eene private zaak gold and as such the Gov. deem it not necessary to give any orders. Men zou dus zeggen dat Raffles, thans vervuld met het plan om zelf een boek over Java te schrijven, niet meer zoo ijverig was in het verleenen van hulp als te voren. Had hij destijds M. schatten laten verzamelen op ethnologisch en ander gebied, hij zal (wanneer hij het heeft beleefd) vreemd hebben opgezien, toen deze verzamelingen werden verkocht aan de E. I. Company, waarna alles werd overgebracht naar het East India House (Widow p. 604; 605). Mackenzie overleed in 1821. Uit Wilson's catalogus blijkt, dat M. o.a. 36 Jav. handschriften had verzameld (opgenoemd aldaar II, 147; zie ook aldaar II, pag. CLXXXV, CCXIX e.v.); van de Antiquities of Java bezat M. 117 origineele teekeningen (p. CCXXIII), van Madoera 51, van Java nog 82 en nog 21 en nog 85 en misschien nog meer niet genoemde benevens copieën van inscripties. Deze heele verzameling is thans in het India Office te Londen. Zie C. O. Blagden, Catalogue of manuscripts in European languages belonging to the Library of the India Office, Vol. I The Mackenzie Collections, Part I The 1822 Collection and the Private Collection (Oxford University Press 1916).

Mackenzie (Kenneth), Lieutenant Bengal Engineers (een verwant van zijn naamgenoot, bij wiens huwelijk hij getuige is), was blijkens Gaz. 21 Aug. 1813 van Oct. 1811 af Station Engineer te Soerabaja op 400 Sonat R. p.m.; als zoodanig fungeerde hij nog in Juli 1812. Wordt Gaz. 1 Mei 1813, zijnde Senior Engineer officer serving on Java, benoemd tot Acting Chief Engineer te Bat.; arriveert aldaar 
17 Juni 1813 ; is in Dec. van dat jaar bezig aan de herstelling van het paleis te Buitenzorg; wordt Proc. 31 Dec. 1813 tevens benoemd tot Superintendent of public buildings and works te Bat. op 550 Java Roep.; neemt met lof deel aan de expeditie tegen Boni, Gaz. 16 Juli 1814; tijdens zijne afwezigheid moest Jongkind, de vroegere Superintendent, weer als zoodanig invallen. In Dec. 1814 wordt hem gelast, aan het Chart office at Buitenzorg op te zenden the several maps, plans and other papers lately delivered to you by Mr. Cornelius. Bij besluit van 27 Oct. $1815 \mathrm{kreeg}$ hij verlof naar Europa wegens ziekte; zijn opvolger werd Watson.

Macleod (A.), Lieutenant, wordt Proc. 18 Jan. 1815 benoemd tot opvolger van Davis als Commandant en Resident van Banjoewangi; neemt de residentie 3. Maart 1815 over van Colonial Lieutenant $\mathrm{H}$. von Ranzow, en blijft hier als zoodanig tot de teruggave.

Macleod (D.), Captain, gaat April 1814 met de expeditie naar Bali; wordt bij General Orders van 6 Jan. 1815 benoemd tot Major of Brigade; Proc. 1 Jan. 1816 ter vervanging van Williams benoemd tot Assistant Resident te Samarang; aanvaardt deze betrekking 11 Jan. Proc. 11 Maart 1816 benoemd tot Commandant en Resident van Soemenap ter vervanging van Clark; neemt 23 April deze residentie van hem over en blijft er tot de teruggave, toen E. J. Roesler optrad, die 12 Nov. 1817 (Van Deventer p. 209) Resident werd over het heele eiland Madoera.

Macquoid (Thomas) was geb. in Ierland; zijn zegel draagt drie torens, waartusschen een kruis; motto: In hoc signo vinces. Was na te Penang te hebben gediend (vanwaar Raffles hem kende) ambtenaar (Superintendent of nigrees) op Ambon en vertrok in Mei 1812 na bekomen aanbiedingen van Raffles vandaar naar Java for the advancement of his private interests, schreef de Resident aldaar 25 Mei aan dezen laatste, onder bijvoeging dat your knowledge of his qualifications verdere aanbeveling (die echter in ruime mate werd verleend) overbodig maakte. Den 7 Juni 1812 kwam hij te Bat. aan en vertrok direct naar Samarang, waar Raffles toen was, die hem 25 Juni benoemde tot Malay translator op 300 \$; den 30 Juni kwam M. terug te Batavia, doch was den 16 Juli weer in O. Java, op welken dag Raffles berichtte hem te hebben benoemd tot Superintendent der koffiecultuur over het gansche eiland en Landdrost

D1. 92. 
van Buitenzorg with a general superintendance over the Batavian and Preanger Regencies, op 500 \$; als Superintendent der koffiecultuur trok hij geen salaris, misschien omdat destijds Tency nog leefde, die het in de Preanger óók was! Den 21 Sept. 1812 vinden wij hem als Landdrost te Buitenz. 'Tency was 8 Sept. overleden; bij schrijven van 10 Sept. belastte de Regeering daarop M. met de opname van diens kas en de overname zijner werkzaamheden; door de verplaatsing van Couperus naar Bat. in Nov. 1812 moet Macquoid Resident van de heele Preanger zijn geworden en in Mei 1813 door de opheffing der residentie Krawang ook dáárvan, zonder dat ooit wordt vermeld, dat hij de ambtenaar is die profiteert van het vacant komen of de intrekking dier verschillende ambten. Het ging alles zoo geheimzinnig, dat men eerst na alle besluiten te hebben verzameld en gecombineerd, begrijpt hoe de vork in den steel heeft gezeten.

Den 5 Nov. 1812 werd hij benoemd tot Voorzitter der commissie voor den landverkoop in de Preanger en Krawang, waaraan hij persoonlijk deelnam. Den 19 Maart 1813 assisteert hij als Malay interpreter bij de svereenkomst te Serang met den Sultan der Bantamsche Bovenlanden, en 20 Juli 1813 evenzoo bij eene conferentie met de Sultans van Cheribon. Proc. 23 Juni 1813 wordt hij provisioneel bencemd tot Superintendent van het Salt Department, waarop hij van Aug. 1813 tot Jan. 1814 eene reis naar O. Java deed tot overname der zoutpachten; bovendien voegde Raffles hem bij schrijven van 8 Oct. 1813 aan Eales toe, ter bespoediging van den landrente-aanslag en speciaal with the view to his undertaking the settlement of the districts of Japara and otherwise rendering you every assistance that you may require. Naar aanleiding daarvan had Macquoid zijn merkwaardigen twist met Hope (zie aldaar), die hem een ,friend” van Raffles en intimus van Flint noemde. In Januari 1814 sloot hij namens het Gouv. de contracten met de gewezen eigenaren van Probol. en Bezoeki. Voor zijne moeite met den aanslag van Japara kreeg hij Proc. 8 Maart 1814 nog extra 500 Java Roep. p. m. Bij schrijven van 11 Jan. 1814 beperkte Raffles zijne bemoeiing met de koffiecultuur tot de Preanger. In Juni 1814 trok hij als translateur 600 Java Roep., als Superintendent van het zout 1.000, als Resident 1.100, samen 2.700 Java Roep.; bovendien werd hij bij Proceed. 18 Jan. 1815 tijdelijk belast met de superintendentie der posterijen, naar aanleiding van Addison's overlijden. In 1816 was hij nog steeds Superintendent der posterijen. Het residentschap van Buitenzorg moet hij in Oct. of begin Nov. 1815 aan 
Hardy hebben overgegeven, maar hij bleef Res. der Preanger; als Malay translator werd hij door Methven vervangen; zijne verdere ambten schijnt hij tot de teruggave te hebben behouden. Proc. 21 April 1815 wordt hij ter vervanging van Methven aangewezen als lid der commissie on the public institutions etc. of Bat. and the Environs; bij schrijven van 10 Aug. 1815 krijgen zij beiden met Hardy eene opdracht tot invoering der nieuwe politieregeling in de Ommelanden en tot bepaling der grenzen en invoering der Regul. I A.D. 1815 in de nieuwe residentie Buitenzorg. Bij Proceed. 22 Aug. 1815 werd M.'s salaris als Resident verhoogd tot 1.500 Roepijen, representatiekosten incluis. Ook zijne werkzaamheden als Resident waren zeer bizonder; zelf beheerde hij namelijk de verkochte doch teruggenomen Krawangsche landen op den voet van een particulier land en liet zijne Assistenten het bestuur voeren over de eigenlijke Preanger. In verband daarmee bouwde hij een huis te Wanajasa (natuurlijk in heerendienst), trok daarvoor 100 Java Roep. per maand huishuur, en verkocht in 1816 dat huis voor 6.000 Java Roep. aan Comm. Generaal. Voorts trok hij $10 \%$ der douanerechten te Indramajoe, speciaal van de koffie; om die te verhoogen werd 9 Dec. 1814 expres het Cheribonsche douanekantoor aldaar op den rechteroever der rivier onder Macquoid geplaatst, wiens gezag overigens enkel de landen aan den linkeroever omvatte; zijn opvolger taxeerde de baten hieruit op 3.000 Java Roep. per jaar; eindelijk had hij 3 pond (in natura) per pikol koffie als spillage bij afscheping te Karangsamboeng en nog 1 à $2 \%$ voor indroging. In het laatst van 1815 zat hij in de commissie Lawrence c.s., en was dus weer werkzaam in O. Java. $\mathrm{Hij}$ is een der onderteekenaars van het afscheidsadres van Raffles' persoonlijke vrienden, Gaz. 6 April 1816.

$\mathrm{Na}$ de teruggave bleef hij op Java; eerst in April 1817 vernemen wij van zijn aanstaand vertrek. Raffles vergat hem ook toen niet, maar reserveerde voor hem bij het ontwerpen van Singapore een perceel grond (Campbell I, 623). Hij kwam later te Bat. terug. In 1821 is hij lid der firma Skelton en Co. met J. Davidson en D. A. Fraser. Dat jaar overleed Philip Skelton. In 1823 logeerde Raffles' tweede vrouw eenige dagen bij hem (Widow p. 551).

Blijkens de krant gaat Macquoid naar Europa einde 1824 of begin 1825. In 1826 ging hij te Bat. failliet; het jaar daarna zat hij doodarm in Engeland. De firma Macquoid, Davidson en Co. wordt ontbonden 1827. In 1830 is hij weer te Batavia. Zie nog Priangan I, 297; Van der Kemp, Herstel p. 227. 
Mijn oordeel omtrent hem blijft weifelend. Iemand die met twee inl. Hoofden in de Preanger het contract van 28 Sept. 1814 kon sluiten, was òf een schelm òf een dwaas. En voor een dwaas hoeft men dezen gewiksten zakenman niet te houden. Uit zijn huwelijk met Elisabeth Francis Kirwan (sic) wordt 3 Aug. 1822 te Bat. gedoopt de dochter Elisabeth Francis, geb. in Krawang 2 Maart 1822.

Maitland (Thos.), officier der Royal Navy, landde den 30 Aug. 1811 te Soemenap met Captain Harris, als wiens secretaris hij fungeerde en die hem het bestuur aldaar opdroeg, toen hij zelf Soemenap verliet; bleef hier tot midden October en nam toen de gansche kas mee; werd 18 Oct. vervangen door Yule, die rapporteerde: „The only public document that he (Maitland) left behind him is a copy list of old practice belonging to the Government House, together with half a sheet of paper containing an abstract of the monthly income collected at Samanap".

Of hij dezelfde M. is, die Proc. 4 Jan. 1812 op een salaris van 250 \$ wordt benoemd tot First Assistant van Flint, bij het Boschwezen, is mij niet bekend.

Martheze (T. P. A.), geb. te Amsterdam 1783 (zijn vader was burger aan de Kaap de G. Hoop), kwam in Indië 1802 als Assistent, is 1809 en 1810 Kapitein en Aide-de-camp van Daendels, bij de verovering Commissaris over de wegen en posterijen. Proc. 28 Nov. 1811 wordt vermeld zijne benoeming tot Inspector of the road from Bat. to Buitenz. and of the Eastern and Western roads between the same. Wordt Proc. 7 Maart 1812 in plaats daarvan inspecteur van den weg tusschen Buitenz. en Karangsamboeng. Wordt 30 Juli 1813 Schout te Tjibinong, doch reeds 20 Aug. 1813 ontslagen, om 1 Sept. 1813 conform last der Regeering de landen van wijlen Zimmer in Krawang over te nemen als administrateur onder toezicht van Resid. Macquoid, die hem 26 April 1814 bovendien, zonder vermeerdering van zijn salaris ad $75 \$$, voordraagt voor Assistant in Krawang; hierop is de Regeer. ingegaan, want in 1814 en volgende jaren, tot minstens Dec. 1816, ontmoeten wij hem als Assistant Resident in Krawang met standplaats te Indramajoe en speciaal belast (althans in 1814 en 1815) met de Government lands aldaar, van welker opbrengst hij $5 \%$ trok boven gezegd salaris. Werd 1817 Resident van Menado. 
Meares (R.), Captain, daarna Major, werd, blijkens Proc. 1 Nov. 1811, na de inname van Batavia commandant der stad tot op 11 September, toen het Britsch bestuur werd gevestigd; als zoodanig bewees hij goede diensten, waarvoor hij 1 Nov. eene toelage van $375 \$$ p. m. erlangde, en thans met ingang van 11 Sept. 1.1. werd benoemd tot Town-Major op 250 \$. In die qualiteit was hij belast met de zorg voor de krijgsgevangenen; tevens was hij reeds 16 Nov. 1811 commandant van het Amboynese corps. Nahuijs (Herinneringen p. 84) spreekt van hem als ,den braven Engelschen Town-Major Mearis.... dien edelen officier”, die N. ,regt broederlijk en ridderlijk" onthaalde; ,nog leeft hij in mijn dankbaar hart, die zijn krijgsgevangen vijand met waarlijk broederlijke liefde behandeld heeft”. In 1812 ging hij als Malay interpreter (Widow p. 115) met de expeditie naar Palembang en was een der weinige Europ., die Gillespie vergezelden op zijn hachelijken tocht naar den kraton (Conquest p. 139; 168). Wordt bij General Orders van 28 Juli 1812 aangewezen to command the troops and to be Resident at Palembang and Banca op 750 \$ (Proc. 15 Aug. 1812). Als Town-Major werd hij Gaz. 22 Aug. 1812 vervangen door Travers. Bij een inval van den afgezetten Sultan van Palembang werd M. kort hierna doodelijk gewond, zie Gaz. 24 Oct. 1812; zijn lof werd verkondigd bij Gen. Orders 22 Oct. Zie nog Bijdr. 1897 p. 369 ; Kielstra, Indisch Nederland p. 203 e.v.; Van der Kemp, Herstel p. 347.

Methven (Cathcart), Lieutenant 20th regiment Bengal Native Infantry, wordt Proc. 13 Mei 1812 benoemd in eene commissie tot onderzoek van Bantamsche zaken; hij komt dat jaar en nog Proc. 28 Mei 1813 voor als Malay translator en Assistant van Resident Yule aldaar, op 150 \$. Uit een brief van dien Resident dd. 28 Mei 1813 blijkt, dat M. belast was geweest met eene zending naar de Lampongs om aanknoopingen met de Hoofden aldaar te bewerkstelligen, wat mislukte. Wordt bij schrijven van 14 Sept. 1813 provisioneel op 400 \$ benoemd tot Assistant to the Resident of Palimbang and Minto, doch vertrekt reeds 30 Nov. 1813 met Captain Colebrooke naar Bengalen (naar aanleiding der affaire Robison), van waar hij eerst 27 Aug. 1814 te Bat. terugkomt, waarop hij Proc. 31 Aug. 1814 tot Malay translator to Govt. wordt benoemd, en Proc. 14 Oct. 1814 als opvolger van Van Heerdt tot Assistant to the Resident of Buitenzorg, of wel tot Head Assistant (Gaz. 12 Nov. 1814) op 330 Java Roep. Bij Gaz. 14 Jan. 1815 werd hij benoemd 
tht waarnemend Resident der Ommelanden tot aan de komst van Hardy (die intusschen den last kreeg om te blijven waar hij was); op dienzelfden dag neemt hij de residentie over van Van Doorninck; hij bleef haar waarnemen, tot dat hij den 25 April 1815 met Raffles op reis ging als diens Acting Secretary, zonder dat iets blijkt van eene benoeming als zoodanig; eerst na afloop dier reis werd hij, ter vervanging van den in Januari overleden Addison, bij Proc. 10 Aug. 1815 benoemd tot Assistant Secretary to Govt. in the Judicial and Revenue Depts. Over de bizondere opdracht van denzelfden datum zie onder Macquoid. Hij bleef intusschen Malay translator en werd Proc. 12 Sept. 1815 nog lid van het Revenue Committee. Na Raffles' aftreding veranderde dit. Gaz. 30 Maart 1816 lezen wij : „Lieutenant Methven, Ass. Secretary to Govt., is ordered to take charge of the Military Dept., and the correspondance in the Revenue and Judicial Dep. will in future be addressed to the Secretary to Govt." Hij was een der onderteekenaars van het afscheidsadres van Raffles' persoonlijke vrienden, Gaz. 6 April 1816. Later in dat jaar was hij lid der naar Bandjarmasin gezonden Eng. commissie. In 1819 vinden wij hem bij Raffles te Benkoelen (Bijdr. 1900 p. 488). In 1821 bezat hij een perceel grond te Singapore (Campbell I, 624).

Meijer (J. C. L.), broeder van L. W. Meijer, werd 25 Nov. 1811 benoemd tot provisioneel Assistent van den Landdrost van Buitenzorg, A. Hartsinck. Zijne vrouw heette M. P. Roelofs. Hij zal de kapitein Meijer zijn, die volgens Nahuijs (Herinneringen p. 83) ,reeds vóór de capitulatie van Java van zijn vaandel was gedeserteerd, op het voorbeeld van zijn ouderen broeder Lieve Willem Meijer, die zijn vaderland verraden en de Engelschen bij hunne landing zijne diensten aangeboden en bewezen had".

Meijer (Lieve Willem), geb. te Utrecht (zoon van J. J. Meijer, predikant te Batavia), kwam 20 Mei 1791 op Java als botteliersmaat; was bij de verovering Secretaris-Generaal; werd bij Proc. 28 Nov. 1811 tot Dutch Secretary to Govt. benoemd, maar heet in Nederl. bekendmakingen uit het begin van den Eng. tijd ook nog wel Secretaris-Generaal (zooals reeds in eene van 12 Oct. 1811) en teekent zich ook aldus. Door Daendels was hij in April 1808 belast geworden met eene zending naar Nederland (Dr. de Roo I, 25*). Hij ging over Amerika, kwam Sept. 1808 te New-York (De Roo I, 26*) en van daar 9 Jan. 1809 in Engeland, waar hij 2 maanden 
bleef $\left(\mathrm{I}, 27^{*}\right)$; kwam in Maart 1809 in Nederland, kwam 23 Dec. 1809 in Amerika terug (I, 34*) en bleef daar 6 maanden, (I, 44*). Vertrok naar Batavia ultimo Mei 1810 (De Roo I, 388) en kwam daar aan 10 Sept. 1810 (De Jonge XIII, 478), waarop Daendels hem benoemde tot Tweeden Secretaris-Generaal. Van Polanen noemt hem ,den lafhartigste der menschen” (De Roo I, 42*).

Men zou dus zeggen, dat zijne speciale verdienste zijne kennis van het Engelsch was; als botteliersmaat en in Amerika, waar hij zelfs in het Engelsch had gevrijd met A. M. Ricketts (die hij bij het beneden te noemen testament tot universeele erfgename verklaart, ofschoon zijne Indische vrouw nog springlevend was), had hij allicht meer gelegenheid gehad dan anderen om daarvan wat op te steken. Bij Dr. de Roo zien we hem (I, 94) in 1808 ,in gebroken Engelsch" met een Engelschman spreken, doch onder omstandiyheden die doen denken, dat hij zich toen van den domme hield; na 3 jaar dagelijks onder Engelschen te hebben verkeerd, beweert hij in Jan. 1815, dat hij ",de Engelsche taal oppervlakkig verstaat” en ,niet ferm genoeg” daarin is om de wonderlijke tegenstrijdigheid te ontdekken tusschen den Eng. en den Holl. tekst der publicatie van 1 Maart 1813 betreffende de Lombardbank. Dit klinkt zonderling, ofschoon Meijer, na eind November 1811 met Raffles op reis te zijn gegaan en in Jan. 1812 teruggekeerd, bij Proc. 14 Febr. 1812 in zijn werk was beperkt geworden tot het vertalen uit het Eng. in het Nederl., terwijl Robison was benoemd tot Head Dutch Translator en dus waarschijnlijk in het Eng. vertaalde. In Febr. en Maart 1812 vinden we hem als "Commissaris in de Cherib. en Crauwangsche zaaken” (als hoedanig hij de Cher. Sultans naar Buitenz. begeleidde) en in Juli bij Raffles te Samarang; in zijn testament van 24 Sept. 1812 (Piepers) heet hij nog steeds Secretaris-Generaal bij het Hollandsch departement. Bij eene publicatie van 1 Oct. 1812 in de Java G. G. wordt hij wegens voortdurende ziekte ontslagen met behoud van rang en vol traktement; Proc. 10 Oct. 1812 staat hij, met het enorme bedrag van $800 \$$ p.m., bovenaan op de pensioenlijst als gewezen Dutch Secr. to Govt. Misschien was de oorzaak van Meijer's val zijn gekonkel met Hope te Samarang, althans Hope schrijft 14 Febr. 1812, dat hij bij zijne zonderlinge afkondiging van 6 Febr. betreffende de bonken is geholpen door Meijer. Mogelijk had deze dus de heele zaak op touw gezet om er een voordeeltje uit te slaan, door Bataviasche bonken te Samarang tegen veel beteren koers te kunnen wisselen tegen zilver. Hij was intusschen reeds Proc. 
1 Nov. 1811 zonder salaris benoemd tot Superintending President der Weeskamer, als hoedanig hij ook Proc. 23 Dec. 1812 voorkomt; eerst Proc. 9 April 1813 na den dood van B. Smissaert wordt hij gesalarileerd met 500 \$, met intrekking van het pensioen; ook was hij, blijkens Proc. 28 Mei 1813, President zonder salaris van Boedelmeesteren, als hoedanig hij 1 Nov. 1813 wegens ziekte werd ontslagen. De gewezen Secretaris-Generaal van Daendels had zijn rokje al mooi gekeerd, zooals blijkt Gaz. 16 Aug. 1813, alwaar hij, naar aanleiding van een brief over de in Nederland thans heerschende ellende, zijn stadgenooten toeroept: „Leerd tog eindelijk alle uwe ware vrienden en vijanden kennen en uwe onderdrukkers van uwe beschermers onderscheiden!" Of hij middelerwijl nog met vertaalwerk werd belast, weet ik niet; dat moet wel als hij de schuld droeg der publicatie van 1 Maart 1813 over de Lombardbank ${ }^{1}$ ); wel dat Goldbach den 18 April 1814 uit Soerabaja schrijft: „Men verhaald hier dat L. W. Meijer, over de advertentie, in de courant van den 19 Maart te vinden (dus de publicatie van 16 Maart 1814), verschil met den Gouverneur gekregen hebbende, bij brief zijn ontslag had gevraagd". Dit ontslag kreeg hij echter eerst Proc. 18 Jan. 1815 naar aanleiding van zijne ergerlijke slordigheid als Presid. der Weeskamer, waarvoor hij 22 Dec. 1814 al was geschorst. Volgens Raffles (brief aan Supr. Gov. 18 Febr. 1815) gaf het ontslag van Meijer en van den secretaris der Weeskamer De Hoogh te Bat. groot genoegen. Zijne verantwoording (in Proceed. 18 Jan. 1815) toont een volslagen gebrek aan plichtsgevoel; hij verklaart o.a. kalm weg (alsof dit eene verontschuldiging was) dat hij de instructie voor de Weeskamer nooit heeft ingezien en dat hij ,,met mondelinge voorkennis” van Raffles als Pres. der Weeskamer tevens deelgenoot was in de Opiumpacht! (Het contract ter zake van Meijer, B. W. Westermann, een Armeniër en drie Chineezen dd. 6 Mei 1813 is te vinden bij notaris Piepers no. 1785 ; de drie Europ. hadden elk $1 / 6$ in die pacht). Het ontslag schijnt tevens 's mans failliet geweest te zijn, althans de Gaz. van 18 Febr. 1815 bericht den a.s. verkoop door de Weeskamer van zijn ,tuin”, denkelijk denzelfden, op Rijswijk, dien hij in de Gaz. van 2 Arpil 1814 te koop presenteerde en waar den 24 Aug. 1814 het nationale feest was gevierd, waarbij zoo zwaar gedronken was. Op dit pand had de Weeskamer eene hypotheek en wegens zijn geknoei als President dwong de Regeer. de kamer die

1) Volgens verklaring van Baud 23 Jan. 1814 was Muntinghe aansprakelijk voor de fout in de publicatie van 1 Maart 1813 over de Lombardbank. 
hypotheek op te zeggen. Na zijne rampspoeden kwam deze heer echter tot inkeer: bij testament van 10 Mei 1815 (Piepers no. 3578, dus toen hij failliet was) maakte hij zijne vrouw tot universeele erfgename; het ,miniatuur portrait" van zijne Yankee girl bestemde hij voor... Pastoor Wedding.

Hij was 1797 te Bat. getrouwd met Helena Wilhelmina Nicolaas van Batavia, weduwe van den boekhouder Petrus Cornelis Groeneveld, die hij bij zijn insolvent overlijden te Bat. 9 Aug. 1822 achterliet. Den 18 Sept. 1814 adopteerde hij een kind bij eene Balische vrouw.

Middelkoop (Jacob Albcrt van), geb. te 's-Gravenhage, in Juni 1793 op Java gekomen, was Onderkoopman te Samarang toen N. Engelhard daar als Gouverneur zetelde, en bij de verovering Landdrost aldaar. Alle papieren van zijne hand, welke ik onder oogen kreeg, gaven denzelfden onaangenamen indruk van zijn persoon, kruiperig, zelfzuchtig, intrigant en zoo weinig ontwikkeld, dat zijn Engelsch vaak een nagenoeg zinledig samenraapsel van woorden is. W. Beeckman, gewezen Resid. van Pekalongan, gerepatrieerd 1807, vermeldt hem 1816 in een brief aan N. Engelhard als ,smulpaap en wellusteling”, die aan Daendels ,,de hoeren bezorgd heeft en die zoo schandelijk in zijne besturen heeft gehandeld”; hij werd „niet voor zeer opregt gehouden", zegt Nahuijs (Herinneringen p. 83). Van de landing der Eng. en de groote daling van het papiergeld dientengevolge, profiteerde hij nog op het laatste moment door in gedeprecieerd papiergeld den koopprijs aan het Gouv. te voldoen van een ,landgoed in den Oosthoek", waarna Janssens bij een schrijven uit Oenarang van 13 Sept. 1811 den Landdrost van den Oosthoek machtigde, om aan van M. zijn ,grondbrief” af te geven. Bij de komst der Eng. te Samarang nam hij de vlucht, doch keerde spoedig terug. Hij werd eerst officieel door Captain Robison bevestigd als Landdrost; werd 4 Nov. 1811 als zoodanig ontslagen, doch trad eerst 15 Nov. af, waarna hij er buiten betrekking bleef wonen. In Mei 1815 werd hij aangeklaagd wegens detailverkoop van opium. $\mathrm{Na}$ het herstel van het Ned. gezag werd hij met N. Engelhard uitgezonden om de Molukken over te nemen, waarbij hij het allerraarst liet liggen, zie Bijdr. 1911 p. 524 e.v.

De man schijnt Javaansch te hebben verstaan; hij hielp Raffles althans aan een Nederl. uittreksel van een babad en bezat eene verzameling oude Jav. wetboeken (Raffles, History II, 64 en XLVI). Hij schrijft 9 Dec. 1812 aan Van Boeckholtz te Buitenz., dat het 
hem verheugt dat $R$. heeft ontvangen ,de overgezondene stukken de historie van Java betreffende”; hij zal ook ,het vervolg” zenden; hiernevens ging ,,een tweede gedeelte dier stukken”; het bedoelde ,wetboek” was reeds verzonden ,nevens noch eenige andere van lateren datum".

Als weduwnaar van H. Wens hertrouwde hij te Bat. 19 Nov. 1816 met C. G. Beijlon, weduwe van G. W. Wiese. Hij overleed op zijn land Koepang bij Soerabaja 15 Sept. 1822.

Milne (Reverend $W$.), zendeling en oud-timmerman, komt 9 Maart 1814 uit China te Bat., en wel, zegt de Gaz. van 12 Maart, with the view of publishing a Chinese grammar at Bat. with the aid of the Gov. press, and in communication with the Society, d.i. het Bat. Genootschap. Hij schijnt over Java gereisd te hebben (den 28 Juni 1814 kwam hij van Samar. te Bat.) en voldeed Raffles zeer (Boulger p. 188), doch vertrok naar Bengalen 9 Oct. 1815, zonder, naar 't schijnt, iets te hebben uitgericht. In Widow p. 533 maakt Raffles melding van zijn overlijden en noemt hem my friend. Over hem zie verder Van Troostenburg de Bruijn's Biogr. Woordenboek.

Montanus (F.), geb. te Breda, kwam op Java November 1768 als Predikant, eerst te Bat., sedert 1778 te Samarang, waar hij in den Eng. tijd nog stond op 150 \$. Proc. 28 Oct. 1814 werd bepaald dat hij, of schoon Brückner hem zou vervangen, levenslang dat traktement zou blijven trekken als pensioen en in zijne ambtswoning zou blijven huizen. Was een zachtzinnig man, heel anders dan de bullebijter die hem opvolgde, en na wiens spoedig ontslag deze eerwaarde oude, diep in de zeventig, die nauwelijks nog de kracht had om zijn naam te teekenen, weer is opgetreden. Overleed, zegt Van Troostenburg de Bruijn, in 1816.

Muntinghe (Mr. Herman Warner), geb. te Amsterdam in 1773 als zoon van Mr. Scato M. (uit eene deftige Groningsche familie) en A. El. de Maffé, opgevoed eerst in Engeland, daarna te Groningen, waar hij in 1787 als student werd ingeschreven en in 1796 op stellingen promoveerde. Werd in 1801 Advocaat-Fiscaal bij den Raad der Aziatische Bezittingen; kwam te Batavia 3 Nov. 1805; wordt in 1807 Tweede Secretaris der H. Regeering, in 1808 Secretaris van Daendels, in 1809 Secretaris-Generaal; daarna President van den H. Raad van Justitie en Raad Extraordinair van Indië titulair, welke 
kwaliteiten hij bij de verovering nog bezat. Huwde in Dec. 1809 Wilhelmina Adriana Senn van Basel, geb. te Bat. 18 Aug. 1790 uit Mr. Willem Adriaan S. v. B. en Anna Maria Hooreman; zij was de halfzuster van Wilhelmina Henriette S. v. B., die 17 Aug. 1815 trouwde met Jean Chrétien Baud en is den 21 Maart 1832 hertrouwd met J. H. Westphal. Door dit huwelijk was M. geparenteerd aan Nic. Engelhard en de Van Riemsdijken.

Een man van buitengewone talenten, groote kennis, scherp geheugen, helder oordeel, geestvolle conversatie, achtbaar uiterlijk, beminnelijk en gevoelig; doch zoo noodig doortastend genoeg, zoodat hij zelfs ruw kon optreden en oorvijgen uitdeelen. Had M. reeds bij Daendels, dien hij als vertrouweling van Siberg influenceerde (Dr. de Roo I, 107), in blakende gunst gestaan, Minto benoemde hem al zeer spoedig bij Order van 18 Oct. 1811 tot tweede lid van den Raad, onder behoud van zijn ambt als President van het Supreme Court; het eerste bracht $500 \$$ op, het tweede 800 \$. Den 21 Oct. legde hij den eed als Raadslid af en nam hij zitting, om reeds den 28 Nov. 1811 met Raffles op reis te gaan, die hem gebruikte in onderhandelingen met den Sultan van Djokja; den 11 Jan. 1812 nam $M$. weder zitting, maar sloeg daarna wegens zijne bezigheden bij het Supreme Court wel eens eene vergadering over. Toen in 1812 Raffles en Gillespie beiden afwezig waren in verband met de expeditie tegen Djokja, werd M. bij proclamatie van 23 Mei tot waarnemend Vice-President benoemd, als hoedanig hij 12 Juni zitting nam, zoodat de beide Hollanders M. en Cranssen toen den heelen Raad uitmaakten; daarna kwam Eales er bij. Het volgend jaar werd hij bij publicatie van 28 Mei bovendien President van het Revenue Committee; die heele maand was hij absent als Circuit Judge. Den 2 Nov. 1813 ging hij weder met Raffles op reis (eene eer, die aan Cranssen nooit te beurt viel), maar nam vervolgens niet weer zitting als Raadslid, daar hij onderweg zijn ontslag uit den dienst vroeg, dat hem Proc. 18 Febr. 1814 werd verleend, nadat hij in het geheel 61 Raadszittingen had bijgewoond. Over het aandeel dat M. had in de samenstelling der Code zie Van Deventer p. 133 Rom., Priangan IV, bl. 850. Nu en dan schijnt hij nog als spreekbuis van den ouden Siberg te hebben gefungeerd; vandaar dat Raffles in Proc. 10 Oct. 1812 het bestuur van Pieter Engelhard (Siberg's protégé) over de Preanger roemt; vandaar wellicht ook R.'s ideeën aangaande monopolie en concentratie van handel te Bat. In den strijd tusschen $R$. en Gillespie had M, den eerste gesteund bij een schrijven van 20 Maart 
1814, en als bewijs van aanhankelijkheid hadden M. en Cranssen verzocht om te worden genaturaliseerd als Engelschen; toen Lord Minto naar Europa terugkeerde, beloofde hij daarvoor zijn best te zullen doen (Gaz. 12 Maart 1814). Zijne gevoelens veranderden evenwel, toen er uitzicht kwam op herstel van Nederland als onafhankelijken staat. Volgrens een schrijven van Van Naerssen werd M. reeds einde 1814 verzocht naar Bat. te komen om raad te schaffen bij de gebleken groote ontevredenheid van het Opperbestuur over den gang van zaken op Java. In het volgend jaar kreeg hij van $R$. verzoek, om weder op te treden als Pres. van het Supreme Court, hetgeen hij 30 Nov. 1815 aannam; den 28 Dec. nam hij het presidium over van Hope; traktement $1.760 \mathrm{~J}$. Roep.

Teneinde deel te kunnen nemen aan den landverkoop, verkocht M. voor 10.000 \$ Laanhof aan Ds. Schill (acte Burger 12 Febr. 1813 no. 1050). Kocht onderhands (Proc. 22 Jan. 1813) Pamanoekan voor 30.000 \$, verkocht dit terstond voor 35.000 \$ aan J. Shrapnell en $\mathrm{Ph}$. Skelton; om overschrijvingskosten uit te sparen (waarvan de ecrste kooper vrij was) werd met goedvinden der Regeer. dit land met den prijs van $30.000 \$$ terstond op de tweede koopers ingeschreven, die op de publieke verkooping (25 Jan. 1813) bovendien Tjiasem kochten voor $35.000 \$$, terwijl Muntinghe toen Indramajoe kocht voor 43.000 \$ en Kandanghaoer voor 31.000; had daartoe geld opgenomen bij Van Braam's schoonbroer G. W. van Rijck. Dat dit geene kwade speculatie was, blijkt uit eene acte Drost 21 Juni 1816 no. 8275 , waarbij M. deze landen voor $10.000 \$$ per jaar verhuurt aan twee Chineezen voor 3 jaar; bovendien reserveerde $M$. aan zich het djatihout en verschillende naturaliën.

Van Raffles oogstte M. herhaaldelijk hoogen lof in, zoowel in Java Gaz. 23 April 1814, als in zijne History en zijne Discourse van 24 April 1813 (Verh. Bat. Genootsch. VII), eene Minute van 17 Febr. 1814, Order of Gov. 4 Aug. 1814, die niet alleen in de Jav. Gaz. werd opgenomen (met eene Ned. vertaling, welke de complimenten nog wat aandikt), maar ook in de gedrukte verzameling Proclamations. Zijn particulier leven had echter zwakke punten; met zijne vrouw leefde hij niet samen, maar met drie jeugdige slavinnen, behalve degenen die hij op zijne landen had. Toen het Nederl. gezag hersteld zou worden, werd M. samen met Elout en Van der Capellen benoemd tot Commissarissen-Generaal, doch op het laatste oogenblik verving men hem door Buijskes; voorloopig bleef hij dus President van den H. Raad van Justitie, werd daarna lid der Adviseerende 
Commissie, vervolgens Pres. van den Raad van Financiën 16 Aug. 1816, Commissaris naar Palemb. en Banka 1818 en 1819, Raad van Indië 1819, gaat als zoodanig met verlof, komt na ruim twee jaar terug 14 Mei 1825, wordt als zoodanig op verzoek eervol ontslagen zonder dankbetuiging (Bat. Cour. 7 Maart 1827) en overlijdt insolvent te Pekalongan 24 Nov. 1827. Door familieleden werd dit sterfgeval met diepe verachting besproken. Men zie verder over hem de brieven van Van de Graaff; Bijdr. 1900 p. 349 e.v.; 443 ; 484; 491; 498; 643; Van der Kemp, Teruggave p. 150 e.v.; Herstel p. 165; Ned.-Ind. Bestuur p. 101.

Een naamgenoot, geen familie, was Otto George Veldtman Muntinghe van Veendam, majoor der artillerie.

Murray (A.), Assistant Surgeon, wordt 3 Dec. 1811 uit Bengalen naar Java overgeplaatst (Gaz. 29 Febr. 1812). Wordt bij schrijven van 20 Juli 1815 provisioneel benoemd tot Assistant to the Resid. of Cadoe and Pacalongang. Dat dit dezelfde persoon is, blijkt uit een schrijven van 1816, waarin deze Assistant wordt genoemd „Doctor Murray". Hij trad eerst op als opvolger van de Beauregard in Pekal., gaf dit 1 Nov. 1815 over aan Hunt en aanvaardde 5 Nov. zijn werk in Kedoe, dat hij 1 Febr. 1816 weder overgaf aan Heyland om naar Pekal. terug te keeren (conform Proc. 2 Febr. 1816), alwaar Hunt nu den dienst zou verlaten.

Naerssen (Carel van), geb. te Breda, zwager van den admiraal Ver Huell, kwam op Java in April 1781 en andermaal in Juli 1790; werd in 1808 door Daendels ontslagen als Resident van Grissee, genoodzaakt naar Bat. te gaan en daarna met een kartelschip verzonden naar Cormandel (volgens N. Engelhard omdat Van N. zijn opvolger gerechtelijk vervolgde wegens schuld). Hij bleef toen in de Eng. kolonie en keerde eerst onder Janssens terug; werd ver. volgens handelaar. Bij het Eng. bestuur over Java drong hij aan op onderzoek van zijn gedrag anno 1807 als Resident van Grissee (waarover zie De Jonge XIII, p. XVIII e.v.; p. 300 ; 301) en terugbetaling van de sommen, die hij destijds te vorderen had, waarop hij Proc. 1 April 1812 (een echte Aprilgrap) van blaam wordt gezuiverd, onder bepaling, dat deze beslissing in de courant zal worden gepubliceerd; voorts wordt hem, met erkenning van zijn recht op terugbetaling en belofte dat zijn verzoek aan het Opperbestuur zal worden voorgedragen, een voorschot van $10.000 \$$ toegekend. Zijne aanspraak op 
terugbetaling van ruim $28.000 \mathrm{Rds}$. zilver werd vervolgens door het Opperbestuur bij schrijven van 24 Juli 1812 ingewilligd en de zuivering van blaam had plaats in de Gaz. van 4 April 1812. Nu was aan v. N. door Daendels zijne zwakke houding tegenover de Engelschen verweten; en als iets geschikt was om aan de verdenking van Engelschgezindheid voedsel te geven, was het deze bevoorrechting; v. N. zelf echter beweerde, dat hij na zijne verwijdering van Grissee de eenige persoon te Bat. was geweest ,qui ne ployait pas les genoux pour l'idole", namelijk Daendels. Reeds in Proc. 10 Oct. 1812 komt hij op de lijst van het personeel voor als Resid. van Grissee op 350 \$, waartoe hij echter pas bij schrijven van 11 Nov. 1812 werd benoemd; den 24 Nov. draagt Resid. Hartilieff aan Van Nijvenheim deze residentie (welke ondanks haren naam ondergeschikt was aan den Resid. van Soerabaja) over, doch eerst 22 Febr. 1813 had de overdracht aan Van N. plaats. Reeds dit tijdverlies kenmerkt hem als slof. Zijn salaris was toen 300 \$, later 1.000 Java Roep. en nog later 1.200 Java Roep., waarvan hij echter het revenue establishment te onderhouden had. In $1813 \mathrm{kreeg}$ hij voor $\mathrm{I} / 4$ aandeel in den koop van Goemoelak, en Proc. 3 Febr. 1814 krijgt hij permissie om handel te drijven met het Gouvernement van Ceilon en om als agent daarvan op te treden. Van 1 Sept. 1814 tot 28 Dec. 1815 was hij zelfstandig Resident, niet meer ondergeschikt aan dien van Soerabaja. Met den aanslag der landrente mocht hij zich echter niet bemoeien: eerst was Adams, de Resid. van Soerabaja, daarmee belast, en toen deze was afgetreden, kreeg Williams bij schrijven van 1 Sept. 1814 de opdracht daartoe. Eerst nadat de aanslag was afgeloopen, erlangde Van N. het beheer daarover. De Commissie Lawrence c.s. einde 1815 oordeelde hem lui en slof; Proc. 28 Dec. 1815 verklaart Raffles hem onbekwaam om de landrente te beheeren, zoodat, ofschoon hij Resident bleef, thans op 600 Java Roep., zijn gewest weder onder Soerabaja werd gebracht; maar reeds bij schrijven van 18 Jan. 1816 werd Cotes tot zijn opvolger benoemd; Van N. kreeg 500 Java Roep. pensioen en gaf 1 Febr. 1816 de residentie aan Cotes over. Hij was toen zwaar ziek.

Het is opvallend, dat de twee eenige Nederlanders, die door Raffles voortdurend als Resident zijn gehandhaafd, nl. Doornik en hij, beiden zulke prullen waren, en wel Van N. in die mate, dat men na lezing zijner correspondentie zich afvraagt, wat de man eigenlijk uitvoerde te Grissee; een klerk had het precies even goed gekund. Reeds in 1802 had hij geschreven: Ik betracht de philosophie 
der apathie. Thans was hij bovendien bejaard; ook schreef hij heel geen Engelsch en was vermoedelijk nogal Franschgezind, want een zijner geadopteerde kinderen heette Napoleon. Maar wel blijkt hij een ontwikkeld man geweest te zijn, die goed Fransch verstond, eene flinke boekerij en ,,surgical and other instruments” en een chemisch laboratorium bezat. Wellicht dat hij door zijne persoonlijke gaven de gunst van Minto won, wiens protégé hij was. Evenzoo zendt hij in 1814 aan Raffles curiosa (gamelans, sonohout) en koopt hij voor hem stof- en staafgoud op tot een bedrag van 8.000 \$, ter verzending naar Engeland door Travers; Raffles raadpleegt hem over krissen, vraagt hem ,a paper or two" voor de Verhandel. van het Bat. Genootschap (,there is nobody so competent” zegt hij), en raadpleegt hem over de beteekenis van Javaansche woorden. Hierop antwoordt Van N. (Sept. of Oct. 1814) : „Avant ma catastrophe je m'étais fait une collection assez curieuse par raport à l'ancienne histoire de Java et principalement par rapport au temple de Giri et de son fameux cris, mais tout cela a été perdu; je tacherai cependant de prouver à Votre Excellence la tradition Javane à l'égard du temple et du cris et je crois que si Votre Excellence désire uniquement des desseins des rites, costhumes et des armes des Javans, je crois que Mr. Horsfield sera le mieux en état de vous les fournir, car je me rapelle que se trouvant ici il y a quelques années M. Horsfield a fait prendre des croquis de tout cela". Het is dan ook wel mogelijk, dat de zeven particuliere klerken, die Van N. er op nahield, grootendeels voor den Luit. Gouv. werkten, want op het kantoor zelf werd nagenoeg niets uitgevoerd. Ofschoon Van N. destijds ongetrouwd was (hij was 20 Jan. 1782 te Bat. getrouwd met Wilhelmina Petronella Bosch, stiefdochter van den Gecommitteerde D. J. Smith) en met eene huishoudster leefde, had hij op Java vrij wat familie; Van Nijvenheim, N. van Meeverden, J. J. Reijnst waren oomzeggers. Zijne dochter Charlotte v. Naerssen trouwt te Grissee met C. A. F. Loth in Maart 1814, en zijne dochter Jacoba met A. van Moesbergen van Malakka, landmeter, in Dec. 1814.

Hij was zeer vermogend; zijn door Daendels hem berokkend verlies schatte hij op 40 à 50.000 Rds. zilver; op Rijswijk bewoonde hij in 1812 een groot huis. Hij leende in 1814 ook geld uit aan inl. Hoofden en anderen. Zelf zegt hij, dat hij onder het Nederl. bestuur per jaar wel \$20.000 had overgehouden. Maar Proc. 14 Mei 1816 wordt zijn gedrag in zake zekeren verkoop van hout , highly blameable” verklaard, ,whether from imbecility or other cause”. Dit snuif je 
van Fendall riekt voorzeker anders, dan wat hem nog 4 Juli 1815 namens Raffles was verzocht, in verband met een rapport over Bawean: „In your report the Lieut. Gov., entertaining the highest opinion of your endowments and qualifications for the purpose, relies upon your including the observations you may make on the peculiar languages and usages of the people, with the differences which may appear between them and those of Java and the Eastern islands in the vicinity".

$\mathrm{Er}$ is een bundel correspondentie bewaard, door v. N. vóór Daendels' komst uit Grissee gevoerd met N. Engelhard; hier en daar zijn zijne brieven wel vermakelijk en interessant, en zijne belangstelling in allerlei proefnemingen blijkt even groot te zijn geweest als die van Engelhard. Summa summarum - een dilettant geleerde, een prulambtenaar, een aangenaam mensch.

Hij overlijdt te Grissee 27 Mei 1821, oud 67 jaar; zoon F. van Naerssen, schoonzoons A. van Moesbergen, C. A. F. Loth, T. W. Nagel, die de man was van C. van Naerssen.

Nahuijs (Mr. H. G.), geb. te Amsterdam 1782, gepromoveerd in de rechten te Harderwijk, gaat 1805 naar Indië maar keert reeds 1807 terug; komt eind Nov. 1809 met depêches op Java terug, was bij de verovering lid der Administratie van de Houtbosschen. Ondanks dit vreedzame baantje bood $\mathrm{N}$. bij de landing der Eng. zijne militaire diensten der Regeering aan en werd zoowaar bij den staf geplaatst; schijnt echter geene uniform te hebben gedragen, want toen Garnham hem 15 Aug. gevangen nam, liep hij kans als spion te worden opgehangen (men zie ook het certificaat in zijne Herinneringen bl. 242); werd 20 Aug. uitgewisseld; kreeg daarna eene uniform; werd bij Meester Cornelis gewond en geraakte in krijgsgevangenschap. Hope schreef later, dat hij na den val van Meester Cornelis onzen N. te Buitenz. ontmoette, die een pas had om naar Samarang te reizen; hij praatte echter zoo onvoorzichtig, dat Gillespie en Hope het noodig achtten hem an te houden, waarop Minto evenwel last gaf dat hij zou doorreizen; te Samarang leefde hij als kameraad met de Eng. officieren on account of his great kindness to some English prisoners formerly at Samarang; he bears a very high character among his countrymen for honor and uprightness. Ook Gillespie verklaart in eene nota van April 1813, dat hij zich niet verantwoord had geacht om een persoon van Mr. N.'s avowed principles op het eiland te laten, en dat hij dus, ondanks alle achting, die 
hij persoonlijk voor N. koesterde, hem naar Bengalen had gezonden. Het doet aangenaam aan zoo iets te lezen, des te aangenamer wegens zijne zeldzaamheid; men merke echter tevens op, dat $\mathrm{N}$. bij al zijne ridderlijke eigenschappen tevens een dobbelaar was en wellicht dáárom naar Indië had moeten gaan, waar hij direct overeenkomstig 's Konings wil was geholpen; hij was namelijk de zwager van Schimmelpenninck.

Den 13 Dec. 1811 vertrekt hij als prisoner on parole per Bee naar Calcutta, komt aldaar 22 April 1812 aan; blijkens Proc. 27 Nov. 1812 genoot hij geene toelage als krijgsgevangene, not having been considered in a military capacity or having ever signified a desire for such. Blijkbaar zat hij goed in zijn geld, ondanks dat hij 5 Aug. 1812 uit Chinsura schreef, dat hij na de verovering voor $4.000 \mathrm{Rds}$. was bestolen by the rebels in Krawang. Later verdiende hij bij Quatrebras de Militaire Willemsorde, en kwam 5 Maart 1816 per Arinus Marinus als passagier op eigen kosten te Bat. terug (,,Mr. Nahuis and child" zegt de Gaz.). Hij heette toen Majoor en maakte zich zeer verdienstelijk door het treffen van regelingen voor de a.s. komst der troepen (Van Deventer p. 65). De note gaie bij zijne krijgsdaden vormt het Legioen van Eer, dat Louis Philippe hem later toekende voor zijn heldhaftig gedrag bij Meester Cornelis. In 1823 ontmoette hij Raffles weer te Benkoelen en ontving ook toen weder de bewijzen van diens achting (Brieven over Bencoolen p. 195). Zie ook Van der Kemp in Ind. Gids 1908, p. 437-479.

Nelissen (Jac.), geb. te Mill in het Luiksche, kwam op Java 26 Maart 1808; wordt 1815 aangeduid als ,de oude Eerwaarde Heer N.” en als „Catholijk Prefect” d.i. Praefectus Apostolicus (bij vergissing werd hij ook wel eens Professor genoemd). Zijn salaris bedroeg slechts $75 \$$. In den staat van het ambtelijk personeel $30 \mathrm{Juni}$ 1814 komt hij niet voor. Zijne woonplaats wordt in 1813 (evenals ook die van den koster der R.K. kerk) aangeduid als „Passar Snin bij Weltevreden". Hij overlijdt te Bat. 6 Dec. 1817.

Nightingall (Sir Miles), Major-General van het 69e regiment of Foot (dus King's troops), later Lieut.-Gen., heet (Egerton p. 102) een natuurlijke zoon te zijn geweest van Lord Cornwallis (overleden als Gouverneur-Generaal van Britsch-Indië 1805); landt te Bat. met zijne echtgenoote 15 Oct. 1813 als Legercommandant (Gillespie was reeds vertrokken) en neemt dienzelfden dag zitting als Member of

D1. 92. 
Council; zijn salaris als zoodanig was 1.650 Java Roep. Reeds 2 Nov. legt hij den eed af als Vice-President en neemt hij als zoodanig zitting wegens het vertrek van Raffles, die 3 Febr. 1814 weder presideerde. Den 5 April 1814 vertrekt hij zelf met zijne echtgenoote in verband met de expeditie naar Bali en Makassar; den 4 Juli 1814 komt het echtpaar van laatstgenoemde plaats terug te Soemenap; over land reisden zij vervolgens met veel oponthoud te Soerab., te Samar., te Salatiga naar Buitenz., waar zij eerst 30 Aug. aankwamen; den 31 Aug. woonde N. de raadsvergadering weer bij. Den 8 Sept. 1814 ging hij van Weltevreden over land naar Bantam, maar was 14 Sept. weer in den Raad present. Hij woonde toen op het landhuis Tjimang. gis, dat door de Regeer. van Van Riemsdijk was gehuurd. Hij schijnt verder niet gereisd te hebben, althans hij woonde geregeld de raadszittingen bij, behalve die in Sept. 1815, toen hij op inspectie was. De Gaz. van 28 Oct. 1815 bevat zijne benoeming tot Commander in Chief and Member of Council at Bombay; die van 4 Nov. de advertentie der a.s. vendutie te zijnen huize te Weltevreden; daar niet tevens het huis verkocht werd, woonde hij denkelijk in het Gouv. huis, het oude paleis; den 17 Nov. verschijnt hij het laatst in Rade en den 19 Nov. gaat hij met zijne echtgenoote op het opnemingsvaartuig de Nearchus scheep naar Bombay.

Als mensch stond N. bij Lord Minto hoog aangeschreven (Widow p. 201); hij schijnt een zeer gematigd man te zijn geweest. Addison, die hem a truly good man noemt, vertelt (o.1. pag. 376; 380), dat N. bij zijne komst op Java tegen Raffles vooringenomen was, doch, na zich van alles te hebben doen inlichten, ronduit diens partij koos tegen zijn krijgsmakker Gillespie. Hij raakte dan ook zeer bevriend met den Lieut. Gov. (Widow p. $210 ; 211$ ) en logeerde te diens paleize tijdens diens reis over Java einde 1813 (zie Addison) en wederom in Febr. 1815 (Widow p. 241). Raffles had ook niets dan lof voor hem (Proc. 1 Dec. 1815; Widow p. 226).

Nijvenheim (Joan Louis van), zoon van Carel Joost van Nieuwkerken genaamd Nijvenheim en Cath. Joh. Bosch van Bat., was bij de verovering Drost van Grissee en gaf dit in Dec. 1811 over aan Hartilieff; neemt het echter 24 Nov. 1812 bij diens vertrek weer van hem over en is dus waarnemend Resident, totdat Van Naerssen den 22 Febr. 1813 optrad. Bij schrijven van 21 Maart 1814 benoemt de Regeer. hem tot Assistant to the Resident of Sourabaya op 300 Java Roep. Hij had aldaar het Judicial Dept. onder zich; na Davy's 
vertrek teekent hij ook als Magistrate; Crawfurd noemt hem Juni 1815 Assistant Resident and Baillew, het jaarboekje voor 1816: Second Assistant, en evenzoo Crawfurd in een brief van 16 Nov. 1815 .

Hij was een oomzegger van Van Naerssen; zijne zuster $H$. W. van $N$. was de vrouw van den chirurgijn $N$. van Meeverden van Amsterdam.

Hij overlijdt insolvent te Soerabaja 1822.

Offers $(W$.), geb. te 's Hertogenbosch 1764 , waar zijn vader koopman en meester kleermaker was; hij zelf werd in 1794 lid der municipaliteit zijner geboortestad, in 1802 lid van het Departementaal Bestuur van Braband; kwam 1808 als hofmeester met Daendels op Java, was bij de verovering Landdrost van Krawang, werd bij schrijven van 17 Sept. 1811 als zoodanig gecontinueerd; het salaris was 300 \$. Proceed. 1 Nov. 1811 heet Krawang echter te staan onder een Deputy Landdrost. Den 5 Nov. 1812 benoemd in de Commissie voor den landverkoop in de Preanger en Krawang. Bij publicatie van 28 Mei 1813 werd de betrekking van Resid. van Kraw. en Indramajoe opgeheven; den 10 Mei tevoren echter had Offers de residentie al overgegeven aan Van de Poel. Bij schrijven van 17 Sept. 1813 gaf Raffles kennis van zijne benoeming tot Salt Agent in the Sourabaya Division op 200 \$ (later 440 Java Roep.); hij bleef echter nog 3 maanden belast met het maken van den nieuwen weg door Krawang. Was in 1816 nog Salt Agent, woonachtig te Grissee. Hij maakt den indruk van een zeer fatsoenlijk en niet onbekwaam man. Werd in 1818 Inspecteur-Generaal der Posterijen. Hij overleed oud 63 jaar te Soerabaja 24 Aug. 1826 als Directeur van het Zoutmiddel. Zie nog Van der Kemp, Herstel p. 227.

Pahud (A. D. F.) van Lausanne, vader van den GouverneurGeneraal, kwam in Febr. 1814 op Java en diende terstond een rekest bij de Regeer. in (zie Proc. 29 April 1814), waarin hij verklaarde, met zijne vrouw a considerable part of my life eene kostschool te hebben gehad in Europa (denkelijk te Amsterdam, waar de toekomstige G.-G. in 1803 was geboren) en aan de Kaap, en wel voor jongens en meisjes; hij vraagt nu, zeer bescheiden, om eene woning, een salaris en een voorschot. Hij schijnt toen de toezegging te hebben gekregen van een renteloos voorschot van 5.000 Java Roep., dat hem op bovenstaanden datum werd verleend, en plaatste in de Gaz. van 
16 April eene advertentie betreffende de opening van een jongensen meisjes ,institut”. Hij huurde toen Laanhof van Ds. Schill voor 125 \$ per maand (acte Burger 20 Juni 1814 no. 2209), en woonde daar voortaan als , directeur van het institut tot opvoeding der jeugd"; de eigenaar klaagde echter, dat hij de opgezetenen tot zijn dienst gebruikte. In de Gaz. van 20 Aug. 1814 verscheen eene Essay on female schools, denkelijk van Dr. Robertson, met den raad om meisjes iets degelijks te laten leeren; men zou er uit kunnen afleiden, dat het institut niet razend opnam. In een stuk van 28 Oct. 1815 verklaart Pahud dan ook uitstel noodig te hebben om zijn voorschot terug te betalen; zijne school begon te vlotten, maar hij had verliezen geleden aan paarden, slaven en door diefstal. Eene commissie van onderzoek rapporteerde Proc. 17 Nov. 1815, dat er thans 30 leerlingen waren tegen $30 \$$ per maand, van welke 30 er echter slechts 19 betaalden, terwijl het kostgeld der 11 anderen door de ouders aan Pahud werd gekort op afbetaling van schuld; de maandelijksche onkosten bedroegen echter 5 à $600 \$$; Pahud was bereid om 1.000 Java Roep. per kwartaal af te betalen. De Regeering vond dit evenwel onvoldoende en dreigde hem met de justitie, als hij niet per maand 500 afloste; hij moest dan maar van de ouders leenen, heette het, waarop de arme monsieur 2 Dec. antwoordde, dat hij zijn best daartoe zou doen, want dat eene vervolging de ondergang van zijne school zou wezen. Pahud teekende dan ook 4 Dec. 1815 (Drost no. 7620) eene obligatie groot 5.000 Roep. papier ten faveure van het Gouv., waarbij hij aannam om, te beginnen met 1 Nov., p. m. 500 af te betalen. Inderdaad werd de schuldbekentenis 16 Dec. 1816 geroyeerd.

Hoe het later met die school ging, is mij niet bekend. Vader Pahud overleed als President der Weeskamer te Samarang oud 63 jaar den 9 April 1830. Zijne vrouw was A. Walther.

Palm (?) wordt bij schrijven van 26 Febr. 1813 benoemd tot „Assistant or writer to the Resident of Djapan”; zijn salaris was $75 \$$. Na de overplaatsing van Resident Jourdan en de opheffing der residentie bleef Palm voorloopig met het bestuur belast.

Pemberton (G. R.), Lieutenant 3d Batt. Bengal Volunteers, wordt 27 Sept. 1812 op 200 \$ Assistant der Commissarissen voor de overname der afgestane Vorstenlanden; had als zoodanig te doen met de opname van Djipan en Poerbodadi. Wordt Proc. 22 Jan. 1813 benoemd tot 
Resident van Djipan and its dependencies op 250 \$ plus $2 \%$ on the amount of the revenue collections; aanvaardt die betrekking eerst 4 Maart 1813. Wordt bij schrijven van 2 Sept. 1813 als Assistant voor het verrichten van den landrente-aanslag toegevoegd aan Eales te Samarang op 150 \$, denkelijk extra, want hij bleef Resident van Djipan; bij de opheffing dezer residentie werd niettemin bij schrijven van 24 Jan. 1814 Pemberton belast met den aanslag aldaar; den 25 Jan. schrijft hij uit Samarang (waar hij nog steeds was), dat hij zoo spoedig mogelijk naar Djipan zal gaan to carry into effect the settlement of the lands there, waarmee wij hem in Maart dan ook bezig vinden, thans als waarnemend Collector. Wanneer hij is benoemd tot Collector in Soerabaja, is mij niet gebleken; den 27 Maart 1814 schrijft hij, dat hij daar in die qualiteit is aangekomen; den 11 April maakt Adams zijne aanstelling als Collector of revenue in the division of Sourabaya aan de gemeente bekend. Den 22 Aug. 1814 neemt hij van den vertrekkenden Resident Adams Soerabaja over en treedt dus op als waarnemend Resident, tot hij het ambt 7 Sept. 1814 overdraagt aan Burney. Wegens de benoeming van Williams werd diezelfde maand zijn ressort verminderd met Grissee. Den 17 Juli 1815 gelastte het Hoofdkwartier te Weltevreden hem, zich weder bij zijn bataillon te voegen, dat naar Bengalen zou terugkeeren; doch eerst 8 Sept. geeft hij zijn archief over aan Eckford, komt 23 Sept. te Bat., wordt echter bij General Orders 1 Dec. 1815 bij een ander bataillon ingedeeld, en arriveert nogmaals van Samarang over zee te Bat. op 20 Mei 1816. Misschien valt uit het een en ander af te leiden, dat hij maar half voldaan had als Collector. Van Lawick spreekt later dan ook van heftige ruzie van den Collector te Soerab. met den Resident, maar of hij Pemberton bedoelt, is niet duidelijk. Een gedicht geteekend G. P. staat in Gaz. 9 Jan. 1813.

Piepers (Mr. M. J.) van Middelburg kwam op Java 24 April 1811, vestigde zich als Advocaat en Notaris; aankondiging der vendutie van zijn sterfboedel in Gaz. 3 Aug. 1816.

Poel (Pieter van de) van Goes kwam op Java 28 Maart 1808, huwde te Bat. in $1810 \mathrm{~S}$. H. von Gutzlaff, was bij de verovering oud Luit. Kolonel en Aide-de-camp van Daendels, kreeg Proc. 12 Maart 1813 een baantje bij de Magistrates te Bat., werd in het voorjaar van 1813 Assistant van Resident Macquoid en nam 10 Mei Krawang over van Offers; komt Proc. 28 Mei 1813 voor als Assistant in Krawang 
op 150 \$. Den 26 April 1814 schrijft Resident Macquoid, dat hij aan dezen persoon, die ook de administratie voert der landen van Shrapnell en Skelton in Pamanoekan, de keus heeft gegeven either to continue as my Assistant and give up the administration of these estates or resign the situation of Assistant, en dat hij de voorkeur heeft gegeven aan gezegde administratie; hij beveelt nu Martheze aan. Vermoedelijk is Van de P. toen ontslagen; maar Proc. 14 Sept. 1814 is hij bij het Commercial Committee en 13 Maart 1815 wordt hij notaris te Bat.; in Proc. 28 Sept. 1815 wordt vermeld, dat hij als notaris zijn ontslag heeft genomen. In Gaz. 16 Sept. 1815 vinden wij zijne benoeming tot Assistant to the Resident of the Preanger Regencies; diezelffle maand is hij als Assistant te Buitenz. werkzaam en in Nov. 1815 weer in Krawang, te Wanajasa. Bij de teruggave was hij Head Assistant in de Preanger op 330 Java Roep. nominaal, doch 550 reëel tengevolge van zijne vervanging van Methven. Hij overlijdt als Resident van Tegal 28 Mei 1833 oud 47 jaar. Zijne weduwe was H. S. van Gutzlaff.

Popkens (Mr. Diederik), geboren aan de Kaap 17 Febr. 1786 (zijn vader Mr. Willem Popkens overleed 2 April 1832, was geweest lid van den Raad van Justitie te Bat., later Waterfiscaal; zijne moeder was Aletta Jurriana van Haak; deze leefde ook nog in 1832), kwam Juli 1810 op Java en trouwde 13 Jan. 1811 Elisab. Catharina Vogelaar, geb. 1793, overl. 1820, dochter (bij Susanna Johanna van der Beke, dochter van Willem van der Beke, Raad van Indië) van Jan Jacob Vogelaar van Gale, Oud-Raad Extraord. van Indië titulair, overl. te Bat. 27 Dec. 1822, een der rijkste landheeren van toen (eigenaar o.a. van Struiswijk, waar Popkens woonde); was bij de verovering van Java advocaat. Komt in eene bekendmaking van 7 Oct. 1811 voor als Postmaster te Batavia; het salaris was 250 \$. Den 28 Mei 1812 klaagt hij, dat niet alle postmeesters weten, dat hij Postmaster General of Java is. Wordt Proc. 15 Sept. 1812 ook lid van Curatoren. Toen W. Ainslie tot Postmaster General was benoemd (11 Juni 1814), trad P., die niet onder dezen wilde staan, den 1 Juli 1814 af, nadat hij (Gaz. 25 Juni 1814) als Postmaster of Batavia was vervangen door A. Vincent. Hij hertrouwde 15 Dec. 1822 met F. Mulder, weduwe van Huibert Librecht Senn van Basel, en overleed als lid v. Boedelmeesteren 22 Sept. 1837.

Prinsen (Lambertus), R. K. geestelijke, komt op Java April 1808, 
treedt op als pastoor te Samarang 1809, en verricht daar den R. K. dienst met goedvinden van Ds. Montanus in de Herv. kerk. Den 4 Jan. 1812 wordt zijn traktement op $75 \$$ bepaald, nadat Raffles eerst had verklaard, dat de Katholieke gemeente hem behoorde te bezoldigen. Onder de uitgaven der residentie Sam. over 1813/4 staat zijn salaris onder de „charitable allowances”. Hij schijnt gedurende het gansche Eng. bestuur alhier gebleven te zijn. Wordt later pastoor te Batavia en repatrieert begin 1830 samen met B. Prinsen. Overlijdt te Rietmalen (gemeente Neede) 28 Oct. 1840, oud 64 jaar.

Raban ( $W$.), Major, daarna Lieutenant Colonel, nam deel aan de bestorming van Meester Cornelis en aan de expeditie naar Palembang (Conquest p. 19; 130); is in Mei 1812 Commissaris op Banka; wordt bij schrijven van Raffles dd. 16 Juli 1812 benoemd tot Resid. van Cheribon, wat hij 22 Juli overneemt van Lawrence. Zijn salaris van $500 \$$ werd 15 Sept. 1813 verhoogd tot $600 \$$ benevens $2 \%$ van de netto opbrengst der landrente en $5 \%$ der customs. Misschien hield men hem door zulke voorwaarden voorloopig op Java, want reeds in Mei 1812 (Gaz. 5 Sept. 1812) was hem toegestaan naar Europa te gaan teneinde aldaar te worden gepensionneerd. Toen hij hiertoe andermaal had verzoek gedaan, werd dit bij schrijven van 1 Juli 1814 op de meest vleiende wijze toegestaan, nadat hij reeds verlof naar Bat. had bekomen; den 27 Juni 1814 nam Burney de residentie over en 20 Juli 1814 vertrok R. van Bat. naar Engeland.

Hij was te Cher. tevens militair commandant (General Orders 9 Oct. 1812), een zure en zuinige oude heer; 16 Juni 1813 klaagt hij dat, als er geen herberg te Cheribon is, every creature that passes must come as a matter of course to my house.

Rauws (Sebastiaan), geb. te Heusden, kwam op Java 1807, was bij de verovering Luit. Kolonel; wordt door den Resident van Solo 2 Maart 1812 vermeld als mij Assistant; was aldaar op 200 \$ Dutch and Malay interpreter and notary public. Zijne voornaamste bezigheid schijnt geweest te zijn het vertalen uit het Holl. in het Eng.; draagt eene vertaling uit het Jav. in het Eng. zijne handteekening, dan is dit Jav. eerst overgezet in het Nederl. Wordt 28 Juni 1815 aangewezien tot waarnemend Assist. Res. te Soerabaja (vervanger van Burney), en Proc. 10 Aug. 1815 als zoodanig benoemd. Naar aanleiding hiervan wordt Proc. 28 Sept. 1815 de betrekking van notaris en translateur te Solo afgeschaft. Was gehuwd met C. Breton 
van Groll en de zwager van G. F. Meylan (Van de Graaff II, 71). Wordt 1818 Ommegaand Rechter te Soerabaja. Overlijdt aldaar 1821. Zie nog Van der Kemp, Herstel p. 228.

Recp (C.) is bij de verovering Drost te Bangkalan; evenzoo 29 April 1812. Werd 2 Sept. 1812 vervangen door Davy. Daarna Zoutpakhuismeester aldaar.

Reily (J.), geb. te Chittagong in Bengalen, komt April 1814 op Java als zendeling; was werkzaam te Weltevreden en Samar. Den 9 Aug. 1815 schrijft hij uit Samar., dat the Mission Society at Serampore of which I am a member, hem gelast heeft naar Bengalen terug te keeren.

Robertson (Dr. J.), Superintending Surgeon, komt 11 Maart 1814 van Penang te Bat., op last van den G.-G. Reist in April 1814 met Nightingall naar $\mathrm{O}$. Java; werd ingedeeld bij de expeditie naar Bali en Boni. Reeds Gaz. 26 Nov. 1814 krijgt hij wegens ziekte verlof naar Bengalen; hij vertrekt 23 Jan. 1815.

Robinson $(W$.$) wordt soms verward met W. Robison; de eerste$ was geen officier, doch behoorde tot de Civil Service (Gaz. 4 Juli 1812) en wel van Penang, waar hij Assistant was, tijdens Raffles er fungeerde als Assistant Secretary. Reeds 19 Sept. 1811 vinden wij hem in charge of the Custom and Revenue Dept. te Batavia; Proc. 28 Nov. 1811 wordt hij benoemd tot Acting Sub Treasurer and Civil Paymaster op $500 \$$ en Collector of Customs and Revenues te Bat. op 1.000 \$ (echter was hij ook het eerste reeds vóór dezen datum); bij proclamatie van denzelfden dag daarenboven aangewezen tot Member of Council pro tempore during the absence of $\mathrm{Mr}$. Muntinghe; als zoodanig werd hij 7 Dec. 1811 geinstalleerd en woonde hij vervolgens de zittingen bij van 14 en 20 Dec. 1811, 4 Jan. 1812; bovendien werd hij dienzelfden 28 Nov. 1811 nog benoemd tot Acting Secretary to the Lt. Governor at Batavia during his absence (Raffles ging op reis) from the Western Districts. In Maart 1812 kwam hij als Commissaris te Cheribon om de beide Sultans naar Buitenzorg te begeleiden. In Juni 1812 was hij tegenwoordig bij de verovering van Djokja (Gaz. 4 Juli 1812; Conquest p. 197); in Juli en Aug. 1812 fungeert hij als Assistant Secretary to the Lt. Governor, die zich destijds in Midden-Java bevond; den 
27 Juli zond $R$. hem echter naar Batavia in verband met de uitgifte van Treasury Notes. Zijn salaris was in totaal $1.500 \$$ plus percenten van de Customs en de pachten; als lid van het Court of Requests en van het Revenue Committee trok hij echter niets (als zoodanig benoemd 28 Mei 1813). In 1813 fungeert hij weer als waarnemend Secretaris van Raffles op diens reis over Java, en komt volgens de Gazette op 12 Sept. 1813 met dezen van Soerab. terug; gaat daarna opnieuw met hem op reis in diezelfde qualiteit, doch komt 22 Dec. over land te Bat. terug van Samarang, alwaar hij den Lt. Governor had verlaten. Het is wel curieus dat de Sub Treasurer zoo maanden lang van zijne standplaats afwezig kon zijn. Den 17 Febr. 1814 geeft hij op Goenoengsari een groot feest aan 200 genoodigden ter eere van den verjaardag van Mevr. Raffles. Wordt bij schrijven van 22 Juni 1814 benoemd tot Collector General of Customs for the whole Island; wordt Proc. 28 Oct. 1814 Senior Member van het Commercial Committee, doch treedt af als lid van het Rev. Committee; wordt Proc. 18 Jan. 1815 angewezen om den overleden Addison te vervangen als lid van verschillende standing Committees, doch overlijdt na eene korte ziekte den 22 Juni 1815. Zijne graftombe vindt men links naast die van Mevr. Raffles. In een brief aan het Opperbestuur, geinsereerd in Proc. 28 Sept. 1815, wordt hij zeer geprezen; helaas kwam later in zijne kas als Sub Treasurer een tekort aan den dag van 74.231 Rupees (Proc. 1 en 11 Maart 1816). Ook werden toen drie te Penang geboren onechte kinderen van hem gedoopt, 3 Maart 1816. Hoe wonderlijk het destijds met de bepaling der traktementen ging, blijkt daaruit, dat terwijl Robinson als Collector 2.200 Java Roep. trok en als Sub Treasurer 1.100, zijne opvolgers in beide ambten respectievelijk 1.000 en $2.000 \mathrm{kregen}$; het totaal werd dus verlaagd en het werd heel anders verdeeld; de Sub Treasurer was Dalgairns.

Met hem moet niet worden verward:

W. Robinson, een Baptisten-zendeling, die in Mei 1813 uit Engeland op Java kwam zonder de vereischte vergunning van het Court of Directors, zoodat te Calcutta besloten werd hem terug te zenden (Proc. 17 Sept. 1813); later schonk het Court echter vergunning tot zijn verder verblijf op Java (Proc. 15 Febr. 1816). Hij preekte in ,zeer verstaanbaar Maleitsch" voor de inl. Christenen, waarom de Kerkeraad den 11 Mei 1814 besloot, aan de Regeer. voor te stellen hem het preeken in ,ons tegenwoordig kerkgebouw" toe te staan. De man woonde in 1815 bescheidenlijk in Kampong Bandan en had 
reeds direct (Gaz. 7 Aug. 1813) eene school geopend op Molenvliet. In de Java Directory for 1814 staat hij als English schoolmaster. Hij is de schrijver o.a. van een werk over Maleische orthographie, gedrukt te Benkoelen in 1824; kwam te Benkoelen bij Raffles, die niet veel van zendelingen hield en door Robinson dan ook gehaat werd (Widow p. 502; 517).

Een Lieutenant Robinson, zeeofficier en nautical surveyor, die eene kaart der reede van Muntok maakte, wordt vermeld Proc. 23 Dec. 1812; 28 Sept. 1813. Crawfurd's kaartje van Banka werd (zie zijne History III, 534) opgemaakt naar Robinson's opneming, with the interior from Dr. Horsfield.

Robison $(W$.$) , Captain, later Major of His Majesty's 24th regi-$ ment, wordt niet zelden verward met $\mathrm{W}$. Robinson. Hij was tijdens de expeditie Aide-de-camp van Lord Minto, die hem (zie Lord Minto in India p. 251) vermeldt als getrouwd met eene Hollandsche van de Kaap. Hij verstond en schreef een gebrekkig soort Nederlandsch en zal wel de persoon zijn geweest, die de vertalingen vervaardigde der Eng. proclamaties vóór de verovering van Java. Driemaal werd hij als parlementair naar Janssens gezonden om Java op te eischen (Conquest p. 27 ; 65; 66); ook was hij de persoon, aan wien de overlooper Batenburg beweerde den weg te hebben gewezen om het kampement Meester Cornelis aan te vallen. $\mathrm{Na}$ den val van Meester Cornelis varen de Nisus, President en Phoebus naar Cheribon met Overste Wood en Kapitein Robison ,een afgezondene van Lord Minto, die zich aan het hoofd der inl. troepen bevond" en met ,,den resident"; aan deze macht gaf Cheribon zich over (Prior, Reis p. 197). Daar scheepte Auchmuty zich op de Modeste in en met hem ging Robison naar Tegal, Pekalongan en Samarang, die hij opeischte en waar hij dan als Commissaris optrad, orders uitdeelde en tevens als Prijsagent zich van den buit verzekerde; van Samarang ging hij naar Solo, waar hij 22 Sept. 1811 eene conferentie met den Soenan had; den 24 Sept. vertrok hij vanhier naar Djokja en keerde vandaar naar Samar. terug. Het zonderlinge was, dat hij door Minto niet was gemachtigd tot aanknoopingen met de Vorstenhoven en door Raffles evenmin. Door Minto werd hij benoemd tot Assistant Secretary to Govt. and Secretary to the Lieut, Gov. Den 21 Oct. 1811 werd echter bepaald, dat hij voorloopig dienst zou doen als Principal Secretary to Govt. until further orders, op 1.000 \$; den 1 Nov. $1811 \mathrm{kreeg}$ hij eene toelage van $500 \$$ p. $\mathrm{m}$. van af de landing der 
Eng. troepen tot zijne benoeming. Proc. 4 Jan. 1812 blijkt echter, dat Raffles weinig genoegen nam met Robison's vroeger eigenmachtig optreden aan de Vorstenhoven; mogelijk zat ook de tegenwerking, die Raffles' zwager Flint als Prijsagent ondervond, hem dwars; in elk geval, den 7 Jan. 1812 vraagt Robison op nijdigen toon ontslag als Secretary, omdat hij geen genoegen kan geven, waarop Proc. 11 Jan. 1812 Davidson met de waarneming dier betrekking wordt belast en Rob. bij Proc. 14 Febr. 1812 wordt benoemd tot Head Dutch Translator op 750 \$, belast met vertalingen uit het Holl. in het Eng. Hij vertrekt echter reeds 20 Febr. 1812 naar Samarang en moet reeds 19 Maart 1812 eene instructie hebben gekregen als „Resident at Minto", waarvan een extract in Proc. 27 Nov. 1812 is te vinden; tot eene benoeming kwam het echter niet, daar Meares werd aangewezen. Proc. 10 Oct. 1812 schaft Raffles de betrekking van Dutch Translator af, maar zegt dat hij Rob. zal gebruiken voor a political mission op zijn tegenwoordig salaris. Na de aftreding van Eales werd hij Resident van Palembang en Banka; hij vertrok daarheen 13 Febr. 1813 en begon alras onderhandelingen met den afgezetten Sultan van Palembang, met wien hij tot eene overeenkomst kwam, die zoo weinig in den geest der Regeer. viel, dat hij werd afgezet en vervangen door Court, die over deze zaken later geschreven heeft; vergel. Kielstra, Indisch Nederland p. 206 e.v. Raffles beweerde later (Widow p. 394), dat Rob. zich had laten omkoopen, iets wat Van der Kemp (Bijdr. 1900 p. 335) in twijfel trekt. Den 30 Juli 1813 komt hij aldus in ongenade te Bat. terug, waarop Raffles den 13 Aug. voorstelt, het door Rob. gesloten contract te verwerpen, eene commissie van onderzoek naar Palemb. te zenden en hem binnen Bat. en de Ommelanden te interneeren, totdat die commissie terug is. Vervolgens maakt Raffles Proc. 24 Aug. 1813 aanspraak op eene som van 4.316 \$, die door Rob. niet verantwoord was, wellicht omdat hij deze als een geschenk van den Sultan beschouwde; daarna (Proc. 15 Oct. 1813) werd bovendien restitutie van 12.000 \$ gevorderd als zijnde onverantwoord gebleven bij de verovering van Java (Rob. betaalde die terug); vervolgens werden nog meer aanmerkingen gemaakt op zijn geldelijk beheer, die tot allerlei onverkwikkelijke debatten leidden met een eisch van borgstelling, een beslag op Rob.'s goederen, klachten van dezen over partijdige behandeling, brutaliteiten, weigering om te betalen, een arrest op zijn persoon. Hij was eigenaar van Rustenburg achter Meester Cornelis, dat hij bij zijn vertrek naar Banka (Gaz. 30 Jan. 1813) te huur of te koop had gepresenteerd; 
maar toen het op betalen aankwam van wat het Gouv. vorderde, bleek het, dat hij geene eigendommen bezat en stond Rustenburg op naam van den Prijsagent Thos. Wallis. Robison's brieven over deze kwesties maken geen gunstigen indruk; de man kronkelde en draaide zich in allerlei bochten en toonde weinig begrip van rechtschapenheid, maar of al die pretenties op hem wel strikt billijk waren, blijft evenzeer de vraag. Zijn huis op Rijswijk next door to the Government House and lately occupied by General Gillespie, had hij 18 Sept. 1813 eveneens verkocht (Gaz. 28 Aug. 1813; volgens een kaartje van 1812 woonde hij echter in het 2e huis van Raffles af, waar thans Gang Secretarie is). Hij vertrok 8 Nov. 1813 naar Bengalen per Compagnieskruiser in a state of personal restraint, in zoover hij nergens aan land mocht gaan; hij had intusschen verklaard, dat hij bij den G.-G. over de ondervonden behandeling zou klagen, terwij1 de Regeer. wilde gaan procedeeren om beslag te kunnen leggen op Rustenburg. Er werden nu ook getuigen naar Bengalen gezonden, maar de einduitspraak aldaar was (Proc. 19 Aug. 1814), dat weliswaar zijn optreden in Palembang werd afgekeurd, doch alleen op grond van een error in judgement, zonder kwade trouw; hij was dus uit zijn arrest ontslagen en van verdere vervolging ontheven en Proc. 28 Sept. 1815 werd ook het beslag op zijne bezittingen opgeheven. Rustenburg was al (Gaz. 17 Sept. 1814) als zijn eigendom verkocht. Hetgeen niet verhinderde, dat Raffles nog later, zooals wij zagen, beweerde dat hij zich had laten omkoopen. Wij leiden daaruit af, dat Rob. hem in Bengalen nog vrij wat kwaad had gedaan, en wel door te wijzen op de afkeurenswaardige brieven, door Raffles vroeger aan den Sultan van Palembang geschreven, welke tot den moord der Hollanders hadden geleid; zie Van der Kemp in Bijdr. 1900 p. 335 (die zegt, dat hij zijne klacht bij Minto had ingediend en daarna te Londen), en Herstel, p. 348; 349.

Roos (J.F.) is 1814 en volgende jaren Assistant to the Resident of Pasoeroean. Na de teruggave waarnemend Resid. van Banjoewangi.

Ross (J.C.), koopvaardijkapitein. Hare beschrijft hem als a rough seaman in appearance but of good family and education and in lecture what you would not expect, a sober good man whose word you may depend upon. In de Gazette vinden wij, dat hij 8 Juli 1813 van Bima te Bat. komt als kapitein der Olivia, een schip van Hare, 
waarop hij vrij lang blijft varen; 7 April 1815 van Bandjarmasin met eene lading peper in de Betsy; later daarmee o.a. van Malakka en van Bandjarmasin met treasure. Hij was ook in dienst van Hare op Moloeka als scheepstimmerbaas. In Jan. 1817 zegt deze laatste: „Had I sent a man as Ross to put in charge three years ago (op Moloeka), you would have found it now an important flourishing place. Later stichter van de nog bestaande kolonie op de Kokoseilanden; Darwin bezocht hem aldaar in 1827; in Juli 1910 overleed zijn kleinzoon George Ross als hoofd dier vestiging. Volgens Javabode 14 Mei 1859 is de eerste Ross (van de Kokos-eilanden) overleden in Arrakan (sic). Een bericht van hem over een op de Kokos-eilanden waargenomen komeet staat in de Jav. Cour. 12 April 1843.

De Ross, die als kapitein op een schip van Hare in het begin van 1811 op Banka werd vermoord (Widow p. 44; 46) is natuurlijk een ander; evenzoo Lieutenant Daniel Ross, commandant van het opnemingsvaartuig de Discovery, die Dec. 1812 bezig was aan de opneming van Straat Gaspar in opdracht van de Supercargoes te Canton; vergel. Bijdr. 1898 p. 460. Hij heeft ook de kust van China enz. opgenomen (zie Crawfurd, History III, 533 Appendix).

Ross (Ds. Johan Theodoor), geb. 1755 te Bakel in Braband, komt op Java 18 Juli 1788 als Predikant, trouwt in 1801 Christina Diderika Dircks van Ambon (overl. 24 Oct. 1850, oud 82 jaar), weduwe van den Tweeden Secretaris der H. Regeer. S. D. Oldenzeel; trad eenigszins op den voorgrond als Patriot; wordt door Daendels 3 Dec. 1808 benoemd tot Professor Honorair in de Theologie met eene extra toelage van $2.000 \mathrm{Rds}$. per jaar; was in Juni 1811 ook redacteur der officieele courant; na het vertrek van Ds. F. C. H. A. Cluver naar Malakka in Oct. 1811 bleef R. de eenige Hervormde predikant te Bat. Gaz. 7 Maart 1812 wordt hij bevestigd in zijn rang van Professor Honorair wegens zijn langdurigen dienst en zijne literary qualifications. Waarin 's mans eigenaardige verdiensten wezenlijk bestonden, is mij nergens gebleken; ook schreef hij vrij beroerd Engelsch; toch benoemde Raffles hem bij zijn vertrek (Gaz. Extrao. 24 Maart 1816) tot President van het Batav. Genootschap (als hoedanig hij echter weldra aftrad) en kreeg hij in 1820 den Ned. Leeuw. Zijn salaris was in 1814 p. m. 330 Java Roep. plus 165 huishuur en per jaar als Prof. Hon. nog 2.200. Na het overlijden van den Lutherschen Ds. Jeremias Schill op 27 Oct. 1814 deed Ross ook dienst in 
de Luthersche kerk. Hij zelf overleed in 1824. Zie nog Verhandel. Bat. Gen. IX, p. XXX en X, p. XVIII en XXX.

A. M. C. Ross, dochter van den Dominé, is 1820 de vrouw van den Luit. Kolonel O. G. Veldtman Muntinghe. Deze officier overlijdt 1822 in de Prinsenlaan, waarna zij hertrouwt 1824 met den Chir.Majoor P. J. Godefroy.

Rothenbuhler (Frederik Jacob), geb. te Zweibrücken, kwam op Java 1771, werd te Samarang translateur voor het Javaansch; trad in 1809 af als Gezaghebber van den Oosthoek; bij de verovering was hij Raad Extraord. van Indië supernumerair. Wordt Proc. 13 Jan. 1812 benoemd in de commissie Mackenzie op een daggeld van $12 \$$ benevens reiskosten; moet blijkens Proc. 15 Sept. 1812 alle inlichtingen geven, benoodigd voor den landverkoop in Samarang; wordt 5 Nov. 1812 benoemd in de commissie voor den landverkoop in Soerabaja. Zijn verzoek om ontslag uit de commissie Mackenzie wordt Proc. 22 Jan. 1813 afgewezen, omdat de werkzaamheden toch al haast zijn afgeloopen. Raffles roemt 5 Sept. 1813 zijne kennis en ervaring en raadt Adams aan, zich van zijne hulp te bedienen bij de invoering van het landrentestelsel. In een brief aan Van Naerssen schrijft Rothenbuhler, dat door de depreciatie van het Bat. papiergeld, ,waarvan ik bij de komst der Engelschen noch veele duizende Rds. had, ik zodanig achteruit geraakt ben, dat ik dikwijls zelvs niet eens in staat ben geweest een enkeld glas bier, waarvan ik 's avonds zo veel houde, te kunnen drinken". Niettemin nam hij deel aan den Soerabajaschen landverkoop en bezat hij begin 1816 niet minder dan 118 slaven. Was een zeer knap man, maar een beetje een zeurkous, met een overdreven goed idee van den Inlander.

Zijne dochter Fred. Jacoba was de vrouw van Johan Fred. Roesler van Stuttgart. Rothenbuhler overleed te Soerabaja 21 April 1836, oud 78 jaar.

Roxburgh (G.), cornet der cavalerie, werd bij General Orders te Calcutta 19 Mei 1812 aangewezen voor den dienst op Java; komt echter eerst 30 April 1813 te Bat. met de Java Light Cavalry. Denkelijk een verwant van Dr. William Roxburgh (een Schot, den beroemden directeur der Botanical Gardens te Calcutta, overleden, naar 't schijnt, in 1813) en daardoor verzekerd van sterke protectie. Wordt 15 Sept. 1813 aangewezen tot Assistant van den Commissioner Hopkins op 150 \$; toen deze den 29 Dec. 1813 overleed, werd R. bij 
marginaal besluit met de waarneming van diens betrekking belast. Bij schrijven van 5 Jan. 1814 bepaalde Raffles, dat de opdracht aan Hopkins met 31 Dec. 1.1. als afgeloopen zou worden beschouwd, maar dat R. tot aan de komst van Garnham voorloopig belast zou blijven met het bestuur der residentie Bezoeki, waar hij thans First Assistant was. Bij schrijven van 24 Jan. 1814 werd hij bovendien benoemd tot Collector of Revenue, om in die qualiteit direct met de Regeer. te correspondeeren; hij geeft 14 Febr. 1814 de residentie Bezoeki over aan Garnham, maar neemt haar reeds 12 April 1814 opnieuw van hem over. Hij bleef nu Collector en waarnemend Res. van Bezoeki, tot hij 3 Nov. 1814 beide betrekkingen overgaf aan Davis, naar aanleiding van een besluit, waarbij hij was geschorst op grond van een rapport der commissie voor de Eastern Districts (Proc. 25 Nov. 1814). Niet alleen had $R$. de landrente slordig beheerd, zoodat het Gouv. thans met eene waarde van 200.000 Java Roep. aan onverkoopbare padi belast zat, doch hij had ook een aangeklaagde voor het Resident's Court met rotanslagen tot spreken willen brengen, wat Raffles zeer hoog opnam; daarom werd Proc. 6 Dec. 1814 aanbevolen hem te verwijderen uit zijne residentie. Nog veel later (zie Hageman in Nat. Tijdschr. voor N.-I. 1868 p. 255) was hij in Bezoeki berucht als de booze Toean Rasboen; hij woonde er in het huis van den vroegeren landheer, anno 1868 het residentiehuis. Het een en ander belette echter niet, dat de Regeering den 22 Dec. 1814 Holst de Weerth gelastte, de residentie Banjoewangi aan Roxburgh over te geven, zooals 17 Jan. 1815 inderdaad plaats vond; hij werd er civiel en militair chef. Proc. 18 Jan. 1815 werd evenwel besloten hem te ontslaan at Probolinggo (sic) en hem te gelasten zich weder bij den troep te voegen; hij geeft daarop 20 Febr. 1815 Banjoewangi over aan den Colonial Lieutenant H. von Ranzow en komt 29 April 1815 te Batavia. Daarna kwamen nog andere dingen voor den dag, eerst dat de papieren van Hopkins als Commissaris voor den aanslag der landrente spoorloos waren verdwenen, wat door D. Ainslie aan R. werd geweten; verder, dat hij over de 3 laatste maanden van 1814 ruim 9.000 Java Roep. zou hebben terug te betalen. Hem wordt nu 15 Juli 1815 gelast, voorloopig Bat. niet te verlaten. Daarna (Proc. 10 Aug. 1815) kwam aan het licht, dat hij een Chin. meisje hajd verkracht en aangehouden en bij wijze van straf twee Inlanders op een boom had laten klimmen, die vervolgens omgezaagd werd! Er wordt nu besloten (Proc. 15 Aug. 1815) hem voor een Krijgsraaid te brengen, die hem echter, naar het schijnt, genadig behandelde, 
waarop de Regeer. besloot (Proc. 17 Nov. 1815), hem wegens zijn kastekort voor den Raad van Justitie te Soerabaja te dagen. Hij gaat nu daarheen, maar wordt er in December door den bliksem gedood tijdens een diner bij den havenmeester, die zelf, evenals Pemberton, zwaar gekwetst werd.

Precies de booze man voor een shilling shocker. Wat deed men echter ook zoo'n jongmensch in een afgelegen hoek zooveel gezag te geven?

Ruddall (D.), Lieutenant, komt te Bat. samen met Fendall, op hetzelfde schip, wordt (Gaz. Extrao. 12 Maart 1816) benoemd tot diens Private Secretary, en daarna bij General Orders van 26 Maart 1816 tot Town-Major of Batavia, als opvolger van Travers.

Sack (Herman Johan August), geboren te Lubeck 1766 (doodsadvertentie), komt op Java 1784, was einde 1810 Commissaris Generaal over het Depart. der Marine; wordt Gaz. 29 Febr. 1812 benoemd tot Deputy Accountant te Soerabaja; wordt echter reeds Gaz. 7 Maart 1812 voor dezelfde betrekking te Samarang aangewezen op 250 \$, die hij in Mei 1814 nog vervulde; tevens was hij op 200 \$ Assistant van Flint als Timberstorekeeper. In Juni 1814 en later vinden we hem als Timberstore Accountant te Batavia op 440 Java Roep. en tevens als Subaccountant op 600 Java Roep., welke beide betrekkingen hij nog in 1816 bekleedde. In 1820 is hij (Van de Graaff II, 135) Vice-President der Rekenkamer onder Bauer als President; Bousquet beweerde, dat geen van beiden de nieuwe comptabiliteitsbepalingen kende (Van de Graaf II, 135; 139; 140); hij heette „oud en de fijne puntjes zijn er van af". In 1823 volgt hij zijn landgenoot Bauer op als President der Rekenkamer. Overlijdt 12 Sept. 1834.

Zijne vrouw, die in 1818 overleed, was Anna Cath. Ellis van Waterford in Ierland. Daarna trouwde hij S. C. Riddershoven, van welke hij later scheidde. Hij had een paar buitenbeentjes bij de vrije vrouw Noressa van Celebes, met welke hij op 65-jarigen leeftijd den 30 Maart 1831 trouwde.

Salch (Radèn) was de tweede zoon van Kiai Adipati Soero Adimonggolo en in Augustus 1813 oud 12 $1 / 2$ jaar.

Over den vader het volgende. Deze was, schrijft Goldbach 2 Sept. 1812, de ,natuurlijke zoon” van Pangeran Adipati Soero Adimonggolo, Hoofdregent van Samarang; in 1806 maakte hij zich verdienstelijk bij de bestrijding der Cherib. onlusten; hij was toen Regent 
van Kendal, daarna van Demak; hij had, volgens dezen zegsman, „,voor eene Javaan veel kennisse en gezond begrip; is geen dobbelaar nog amphioen schuiver”, maar wel eigenzinnig bij dienstzaken, ,wanneer hij die ten regte of onregte beschouwd nadeelig voor het hem toevertrouwde regentschap te wezen" (Goldbach zegt dit niet als lof, maar afkeurend); wel is hij ,aan de paperij overgegeeven” (d.w.z. dat hij zijne godsdienstplichten nakomt), maar dit heeft ,nog geene nadeelige invloed op hem gehad"; op eigen verzoek was hij als Regent van Demak ontslagen, omdat hij de eischen, door Daendels aan de bevolking gesteld, te drukkend vond en haar niet steeds daartegen kon beschermen. Bij eene nog aanwezige acte van 18 Dec. 1811 benoemde Raffles hem tot Regent van Samarang met den titel Adipati. Hij had voortaan èn zijne inkomsten als gepensionneerd Regent van Demak, èn die als Regent van Samar. Toen Crawfurd als Resident van Samar. aftrad, beval hij bij een schrijven van 10 April 1814 dezen Regent bij de Regeer. aan als a man of extensive acquirements, niet alleen met de bevolking bekend, maar ook met the literature and history of Java; zijne sphere of ideas is extended far beyond what is common among Javanese of the high quality; bovendien is hij een uitmuntend ambtenaar. Waarop Raffles (die dus den Regent nog weinig kende) den 19 April antwoordde, dat het hem genoegen deed a public officer zoo te hooren prijzen. Misschien was het aan deze aanbeveling toe te schrijven, dat, toen de Regent den 26 April 1814 een pas vroeg voor zijne twee ,children” Radèn Mas Soedjak en Radèn Mas Soemadi om naar Mekka te gaan, zulks gereedelijk werd geaccordeerd.

Wij treffen hem voorts Proc. 30 Juni 1814 (onder de benaming van Adipati van Demak) als Mal. en Jav. translateur met een salaris van 600 Java Roep. aan op het thans gecreëerde Javanese translator's office te Buitenzorg; ongetwijfeld was hij of zijn zoon Saleh de Javaan, met wien R. elken morgen en avond Javaansch las, speciaal de Brata Joeda; zie Widow p. 235. Hij hielp Raffles ook bij het vervaardigen van résumé's van Jav. babads, History II, 64. Bij een schrijven van 17 Juli 1815 wordt hij nog bovendien benoemd tot Regent van Japara; zijn broeder Radèn Adikoesoema zou until his arrival or further orders zijne daaraan verbonden werkzaamheden waarnemen als Patih. Zijne nog aanwezige acte als Regent van Japara is gedateerd 1 Aug. 1815. Bij de Widow p. 235 blijkt, dat toen Raffles omstreeks 20 Sept. 1815 te Tjisaroewa vertoefde tot herstel van gezondheid, hij aldaar tot gezelschap had a party of natives, whose good sense and intelligence had

D1. 92. 
attracted his notice and whom he had brought with him from the eastern part of the Island"; denkelijk was dit weer Adimonggolo met zijn zoon. Eerstgenoemde vertrok dan ook pas 13 Oct. 1815 van Buitenz. en kwam den 30 October te Japara aan, waarop Proc. 3 Nov. 1815 zijne betrekking van translator in the Javanese office wordt afgeschaft; maar op denzelfden dag wordt zijn zoon Radèn Mas Saleh op 300 Java Roep. tot diezelfde betrekking benoemd. Beiden schijnen echter te voren niet steeds te Buitenz. te hebben vertoefd, want op de reis van Raffles in 1815 over Java voegden zij zich in het Soemedangsche bij het gezelschap (5 Mei). Even voor zijn vertrek van het eiland schonk Raffles bij eene beschikking van 26 Jan. 1816 (nader bevestigd bij een officieel schrijven van 14 Febr.) aan Adimonggolo ,the burying ground on Gunung Progoto without any of the cultivated land or other ground near to it” en wel ,in property". Nu was dit stuk grond (waarop eene inl. begraafplaats, alwaar de voorouders der Regenten van Samarang en Japara begraven heetten te zijn) sedert eenige jaren beschouwd als behoorend tot Borljong, en men trachtte thans ook stukken sawah daarbij te trekken; zoodat Resident Boggie zijn best deed om den afstand te vernietigen, doch hij werd door Fendall in het ongelijk gesteld. Eindelijk verleende Raffles den 1 Maart 1816 nog eene acte aan Adimonggolo's zoon Soemo Negoro (die reeds 2 Dec. 1815 was geïnstalleerd als plaatsvervangend Regent van Japara bij afwezigheid van zijn vader), waarbij deze, met den titel Toemenggoeng, tot assistent van zijn vader als Regent van Japara werd benoemd with the eventual succession to the situation provisionally, onder nadere goedkeuring van het Gouw. Wederkeerig schrijft de Resident van Samarang 2 Maart 1816, dat A. en Soekoer naar Buitenz. wenschen te gaan om afscheid te nemen.

Adimonggolo was derhalve een voorbeeld van cumulatie van ambten in een Inlander, welke verborgen werd door hem steeds in eene enkele qualiteit te vermelden, zoodat men eerst na eenig combineeren bespeurt, dat de Regent van Samarang dezelfde persoon was als zijn naamgenoot in Japara en de oud-Regent van Demak. De aanleiding tot dit favoritisme lag waarschijnlijk in de hulp, die hij Raffles verleende bij zijne studiën ${ }^{1}$ ); deze gewaagt in zijne History

1) In ziine Minute van 11 Febr. 1814 ter gelegenheid van de nieuwe inrichting der Revenue en der rechtsbedeeling zegt Raffles (Widow. p. 293) : „Collections of the different law books and institutions of the country are now making and a native establishment has been formed at Buitenzorg, under my 
(II, 61 en 82) van door hem gegeven verklaringen van moeilijkheden en vervaardigde uittreksels uit Jav. verhalen. Hij werd gepensionneerd in 1822. Zie nog Van der Kemp, Herstel p. 249-251.

Zijn zoon, Radèn Saleh, werd, zooals gebleken is, in 1801 geboren; men moet hem niet verwarren met den schilder, die een oomzegger van Adimonggolo was (Bijdr. 1897 p. 4). Saleh werd in 1812 met zijn twee jaar jonger broertje Soekoer naar Bengalen ter opvoeding gezonden, tot groote voldoening van Lord Minto, die zelfs (Gaz. 20 Febr. 1813) bij zekere feestelijkheden te Kidderpore een toast instelde op ,the Regent of Samarang, who entrusted his two sons to British hospitality". De verklaring van deze opvallende onderscheiding ligt daarin, dat Minto had leeren inzien (Minto in India p. 370), dat het grootste beletsel voor den vooruitgang der inheemsche bevolking lag in haar wantrouwen tegen de bedoelingen der Europeesche overheerschers, een gevolg van wederzijdsche onbekendheid met elkanders taal; vandaar dat hij het College of Fort William te Calcutta, dat de beoefening van Oostersche talen beoogde, krachtig steunde. In het algemeen dweepte hij met onderwijs (Life of Minto II, 297). Vader Adimonggolo schrijft intusschen 9 Aug. 1813, dat die opleiding hem per jaar 3.000 \$ kost. Uit Gaz. 11 Maart 1815 blijkt, dat Saleh bij het jaarlijksch examen der Durrumtollah Academy te Calcutta ${ }^{1}$ ) prijzen haalde voor meetkunde, algebra en teekenen. Of het andere kind weggegaan was, blijkt niet; wel dat Saleh den 14 Maart 1815 van Calcutta te Bat. terugkwam; evengemeld examen was dus het eindexamen der kostschool. Raffles prijst hem zeer in zijne History I, 273 noot en in eene Minute van 1819 (Widow, Appendix p. 32) zoowel om zijne kennis (vooral van de Romeinsche en Grieksche geschiedenis!), als om zijne beschaafde manieren en vlug en juist oordeel. Zooals we zagen, begeleidde hij kort na zijn terugkeer Raffles op de reis over Java en werd hij 3 Nov. 1815 translateur in the Javanese office. Maar bovendien had zijn vader, toen $\mathrm{R}$. op die reis te Samarang was, voor hem de waardigheid van Adipati Anom (dus gedesigneerd Regent) gevraagd met den titel Radèn Pandji Notodiningrat, hetgeen was toegestaan; zijne acte

immediate superintendence, for examining and revising the judicial proceedings and for affording to the native inhabitants that facility of appeal", die tot dusver ontbrak en zoo wenschelijk is. Dit zal derhalve geschreven zijn vóórdat hij Adimonggolo's hulp had.

1) Carey spreekt (II, 17) over deze Academy onder leiding van $\mathrm{Mr}$. Drummond en over het jaarlijksch examen. $\mathrm{Zij}$ bestond nog (p. 21) in 1823 . 
als zoodanig is nog aanwezig. Hij heette voortaan Assistant Regent en werd in 1816 (dus 15 jaar oud) een tijdlang met de waarneming van het regentschap van Samarang belast, toen zijn vader wegens zijne ruzie met Boggie was geschorst. Zijne voorname verdienste in Raffles' oogen zal wel geweest zijn, dat deze nu, zonder hulp van Hollanders, direct uit het Javaansch in het Eng. en omgekeerd kon laten vertalen, in plaats van bijv. door Krijgsman uit het Javaansch in het Nederl. en dan door J. H. Hinsch uit het Ned. in het Eng. Men vergelijke Raffles' klacht in zijne Discourse van April 1813 (Verh. B. G. VII p. 14) over het ongerief der vertalingen uit het Javaansch in het Engelsch met een of twee intermediate languages en door personen, die geen verstand van zaken hadden, en ook wat Gaz. 11 Maart 1815 wordt gezegd, dat men gewoonlijk zelfs niet direct uit het Jav. vertaalde in het Holl. maar eerst in het straatMaleisch. Saleh hielp R. dan ook bij de bewerking der Brata Joeda (Hist. I, 410). Dat Saleh merkwaardig goed Engelsch schreef, bewijzen brieven van hem, die nog in het archief berusten, en waartoe de Hollandsche ambtenaren bijna zonder uitzondering onbekwaam zouden zijn geweest. Dat vạder en zoon ook meesters waren geworden in het Engelsche cant, blijkt wel (volgens een rapport van Saleh) uit het antwoord van Adimonggolo, toen Resident Boggie bij zekere gelegenheid vroeg, waarom de gerequireerde koelies niet present waren: ,that the people in the Samarang district had imbibed those sentiments of freedom, which he had always understood to be the wish of the British Government for him to instill into them".

Crawfurd, History I, 48, noemt Adimanggolo a man for vigour of understanding, for sagacity and intelligence far superior to all his countrymen.... His wife (p. 49), born a princess .... he educated to make him a rational and equal companion, and both she and his three daughters made proficiency in Arabic literature and were skilled in that of their own country.... Raden Saleh (de oudste zoon) a youth about sixteen ${ }^{1}$ ), read and wrote the English language with facility and propriety and, with the help of a fine ear, acquired so accurate a pronunciation, that his language could not easily be discerned from that of a well-educated English youth. That this was not a mere mechanical acquirement was satisfactorily proved by the good sense and acuteness of his observations. Ib. p. 76: De vrouw

\footnotetext{
1) Volgens Crawfurd's History I, 217 ging Saleh ook met Crawfurd naar Boeleleng.
} 
en dochters van A. verschenen ook op partijen van Eng. en Ned.; hij zelf was the most punctilious Mahomedan, on essential points, of all his countrymen; p. 83: Toen Saleh uit Calcutta kwam, was hij eerst tegenover zijn vader niet zeer onderdanig, maar eene vermaning van papa bracht daarin afdoende verbetering.

Soekoer, die niet wel bij het hoofd was, sloot zich in 1825 bij de rebellen aan (hij werd eerst 1829 gevat, zie Louw, Java-oorlog I, 365 ; Bijdr. 1896 p. 422; 561). Onder het Ned. bestuur was Saleh, die getrouwd was met eene kleindochter van Prangwedono, eerst Regent van Probolinggo, daarna van Lasem; in 1824 ontslagen (Van de Graaff I, 192); hij leed eenigen tijd aan dezelfde aandoening als Soekoer (ib. II, 203). Adimonggolo en Saleh werden in 1825 gevangen genomen (Louw I, 392 noot 1) en daarna verbannen (Van de Graaff I, 193; II, 169 e.v.; 201). Zie nog Van Doren, Reis II, 252 over het zoogenaamd voorgenomen verraad van den Oud Regent Adimonggolo en zijne gevangenneming.

Troost schrijft p. 354: Den 9 Nov. 1825 was aan boord der Maria Reigersberg (het schip van Troost) Adip. Salro Admigolo, gewezen Regent van Samarang, als staatsgevangene evenals ook zijn zoon, de gewezen Regent van Lasem, Raden Adipati Ario Noto Diningrat; een ander zoon, Soekoer, was al gesneuveld als Hoofd van opstandelingen; de vader ,,bekleedde eene priesterlijke waardigheid”. Troost beschrijft pag. 355 het dagelijksch gebed dezer twee gevangenen zooals een turfschipper dat zou doen. Adimonggolo overleed te Soemenap 20 Juli 1827; de levensbeschrijving door Hardy in Bataviasche Courant 18 Aug. 1827 sluit af met A.'s pensionneering door Daendels.

Salis (A. M. T. de), geb. te Breda, in Juni 1806 op Java gekomen, was bij de verovering Eerste Commies bij den Secretaris-Gen. H. Veeckens; werd bij proclamatie 11 Sept. 1811 voorloopig belast met de betrekking van Landdrost der Bat. Ommelanden; later in dat jaar komt hij voor als Landdrost dan wel Resident daarvan; wordt bij publicatie van 21 Jan. 1812 benoemd tot Bailluw of the Environs of Bat., heet echter daarna ook nog wel Landdrost; wordt Gaz. 14 Nov. 1812 benoemd tot Magistraat te Samarang; was daar tevens Commissioner of the Court of Requests. In het laatst van 1813 werd hij benoemd tot lid van den Raad van Justitie aldaar en Circuit Judge op 400 \$, wat hij schijnt gebleven te zijn tot de teruggave, toen hij Resident van Pekal. en Kedoe werd. Zijn rapport dd. 12 Sept. 1816 over het aldaar gevoerde Britsch bestuur is weinig belangrijk. Zie 
over hem verder Van de Graaff I, 145; 146; II, 136; 193; Van der Kemp, Herstel p. 239; N.-I. Bestuur p. 23. Hij draagt ook wel den titel van Baron of Jonkheer. Zijne vrouw A. C. Penning Nieuwland, met wie hij te Soerabaja trouwde 21 April 1822, overleed in 1825 .

Hij gaat naar Europa 1823 van uit Solo. Repatrieert 1826; wordt 1830 Raad v. Indië; overlijdt als zoodanig 28 Nov. 1834.

Sasse (J.F.) van Helpen bij Groningen, op Java gekomen 1789, bij de verovering Opziener in Tjiandjoer, wordt 2 April 1812 Opziener 1e klas van Limbangan op 100 \$. Verlaat den dienst 1813; is daarna eigenaar van het grasland Kampongdoeri in het Angkeesche; klaagt Nov. 1813 dat hij geenerlei ondersteuning van het Gouv. geniet en zooveel betalen moet voor ,,doctur loon voor mijn beenen”.

Sayer (G.), Captain Royal Navy, commandeert H. M. Leda bij de expeditie tegen Java, neemt deel aan den aanval op Meester Cornelis (Widow p. 94 ; 95 ; Conquest p. 50 ; 66; 73). Na den terugkeer van Stopford bleef hij Senior officer of H. M.'s ships on the station, dus commandant der scheepsmacht in the Java and Eastern seas; na den dood van Sir Samuel Hood was hij zelfs een tijdlang Senior naval officer in India. Steeds bleef hij de Leda commandeeren, althans tot Sept. 1815.

Schenk (M. J. von) was al in 1810 Drost of Resident op Bawean; overlijdt aldaar in die qualiteit Gaz. 18 Febr. 1815. Het salaris was $30 \$$.

Schill (Jeremias) van Kampen, Predikant bij de Luthersche gemeente te Bat., kwam op Java 1789. Ofschoon zijn traktement in 1813 maar 150 \$ bedroeg, met $75 \$$ voor huishuur, was hij eigenaar van de landen Laanhof en Japan. Overleed 27 Oct. 1814. Zijne vrouw heette E. Helmig.

Schill (Jcremias) junior, zoon van den vorige, geb. te Zierikzee 1784, kwam met zijn vader op Java, huwde in 1807 Elis. Adriana Roseboom van Batavia, was bij de verovering Eerste suppoost op het kantoor van den Administrateur-Generaal; wordt 1 Nov. 1811 Dutch Assistant Secretary's office op 150 \$; hij zei daarop echter den dienst vaarwel, doch werd in Maart 1813 op hetzelfde salaris benoemd tot First Assistant bij den Accountant; wordt tevens Collec- 
teur van het Collateraal, wat hij ook al eerder moet zijn geweest, en Proc. 6 Dec. 1814 Sub Accountant.

Wanneer hem werd gelast ,om de colonie te verlaten uit hoofde dezelve geweigerd had een tresaurijnoot in betaling voor zilvergeld te ontvangen", zooals het in Jan. 1815 heet, is mij niet bekend; wel, dat aan die order geen gevolg is gegeven. Dit kan samenhangen met zijne herplaatsing in 1813. In 1816 was hij nog in dienst.

Scott (John), in 1806 koopman te Penang (Campbell I, 639), wordt in Sept. of Oct. 1811 benoemd tot Master Attendant and Marine Storekeeper te Samarang, respectievelijk op 400 \$ en 200 \$. Proc. 15 Sept. 1812 krijgt hij 3 maanden verlof naar Bengalen. Den 29 Mei 1813 schrijft de Resid. van Samar. hem, dat zijne laatstgenoemde betrekking is ingetrokken; hij bleef Master Attendant. Proc. 22 April 1814 krijgt hij verlof om met zijn eigen schip, de Isabella, naar Engeland te gaan en dit voor die reis aan de Comp. te verhuren tot het overbrengen van depêches (in verband met de aanklacht van Gillespie) en bij den terugkeer het te bevrachten voor rekening der eigenaren; zijn broer Robert S. werd zijn plaatsvervanger, maar maakte weldra plaats voor Loudon. Met dit schip ging Travers; het komt 31 Juli 1815 met hen beiden en Flint te Bat. terug, waarna Scott Proc. 10 Aug. 1815 weer tot zijn vorigen post wordt benoemd. In het voorjaar van 1816 kocht hij zoowat al het Gouv. timmerhout te Rembang, Grissee enz. op. Hij overleed te Batavia in 1858.

Scott (Robert), broeder van den vorige en geboren te Penang (denkelijk oude kennissen van Raffles en zoons van Robert S., die in 1811 a trader in the Malay seas was, Widow p. 41; deze oude Scott overleed als koopman te Bat. 11 Dec. 1812), wordt Proc. 16 Mei 1812 Assistant bij zijn broer te Samarang op 150 \$; wordt in Sept. 1812 wegens brutaal gedrag in Rembang door Hope geschorst, doch weldra hersteld. In Jan. 1813 blijkt, dat hij aan particulieren handel doet. Bij publicatie van 28 Mei 1813 werd hij lid der Weeskamer te Samar. op 100 \$ met intrekking van zijne betrekking van Deputy Master Attendant and Deputy Marine Storekeeper. Van 22 April tot 9 Nov. 1814 was hij echter waarnemend Master Attendant aldaar. Proc. 13 Juli 1813 werd aan hem de koop toegestaan van een stuk grond at the South Gate te Samar. for the purpose of erecting a cotton screw and warehouse thereon. Hij deed reeds in 1812 zaken met Deans in Kedoe-tabak. In begin 1815 woonden Deans en Scott samen te Samar. op Bergzicht aan den weg naar Paterongan. 
Daaruit groeide de firma Deans Scott and Co. te Samarang, waarvan Deans in het laatst van 1815 te Bat. kantoor hield en Scott te Samar.; in 1820 werd dit laatste kantoor opgeheven en verhuisde Robert Scott naar Bat.; naar hem heet Gang Scott, terwijl Gang Boentoe eigenlijk kampong Scott genoemd werd; aan weerskanten van deze laatste had hij huizen gezet en meer zuidwaarts een laan aangelegd (het begin van G. Scott tot aan de spruit Menteng), die later is doorgetrokken tot Tanahabang.

Robert Scott trouwt te Bat. 3 Juni 1821 met Catherine Maughan. Verlaat Java 1823. Woont weer te Bat. 1841; overlijdt insolvent te Samarang begin 1846.

Scric̀re (Ant. Lod. Paulus de), geb. te Dalem, kwam 18 Juni 1803 op Java, trouwde 1806 te Bat. met Alida Jacoba Kaijsen (of Kaisen) van Chinsura, de rijke weduwe van Daniel Dat; was bij de verovering Fiscaal te Samarang en werd bij publicatie van 21 Jan. 1812 benoemd tot Fiscaal van het Supreme Court te Bat. op 400, later 300 \$. Wordt Proceed. 9 April 1813 bovendien benoemd tot Superintendent of Shroffs op 200 \$, en Proc. 28 Mei 1813 tot lid van het Commercial Committee zonder salaris. Met behoud van zijn Superintendentschap werd hij Gaz. 14 Mei 1814 benoemd tot Magistrate and Baillieu of Bat. under the new regulations, op 660 Java Roep.; als lid van het Commercial Committee werd hij Proc. 30 Juni 1814 ontslagen, omdat hij, in strijd met de bepalingen, particulieren handel dreef. In zijn baljuwschap hinderde hem dit laatste blijkbaar niet. Den 21 Oct. 1814 werd de betrekking van Superintendent of Shroffs afgeschaft. Hij had intusschen de zaken van het Wisselkantoor zoodanig verwaarloosd, dat Proc. 18 Jan. 1815 besloten werd, tweederde van zijn salaris in te houden ter vereffening van achterstand; Proc. 22 Maart 1815 werd zelfs besloten, hem in zijne betrekkingen te schorsen en hem hypotheek te laten nemen op zijne eigendommen (zijn vermogen werd op meer dan 100.000 Java Roep. netto geschat), maar Proc. 22 Aug. 1815 wordt hij zoowaar weer benoemd tot Baljuw der Suburbs, zoodat hij in staatsie de verkooping zijner goederen kon bijwonen, waarna hij (Proc. 1 Maart 1816) nog ruim 94.000 Java Roep. aan het Gouv. schuldig bleef, die bij termijnen zouden worden afbetaald. Hij maakte zich in 1816 verdienstelijk, door Nahuijs te helpen met de voorbereiding der ontvangst onzer troepen (Nahuijs, Herinneringen p. 107). In Nov. 1816 is hij nog Baljuw en houdt kantoor te Biclara Tjina. 
Commissarissen-Generaal namen te zijnen laste eene rentelooze pretentie over van 32.504 Java Roep., betaalbaar ult. Dec. 1818, terwijl S. verhaal behield op de Chineesche debiteuren van het Wisselkantoor. In 1819 ontmoeten wij hem niettemin weer als Ass.-Resid. voor de politie der Stad en Voorsteden van Bat. (Van de Graaff II, 82).

Volgens een schrijven van N. Engelhard 3 Juni 1825 had ,de nu voortvlugtende Heer A. L. P. de Serière" het kapitaal van het Wisselkantoor ,g'employeert tot voortzetting van zijne particuliere negotie in associatie met wijlen de Heer Couperus in de affaire van wijlen de Heer Kruijthof, en waarin men wilde dat ook de Heer Cranssen participeerde". De advertentie in de Batav. Courant van 25 Dec. 1824, waarbij de Procureur-Generaal zijne arrestatie gelastte (hij was voortvluchtig als gesuspendeerd Ass.-Res. voor de Ommelanden van Bat.) wegens allerlei ,,voor jaren” begane misdrijven, vindt men bij Van de Graaff I, p. 169. In 1827 was hij nog steeds voortvluchtig en liet zijne vrouw zich van hem scheiden; zij overleed te Bat. 14 Juli 1838. Zijn broer de dominé kwam uit na het herstel van het Ned. gezag (Olivier, Land- en Zeetogten I, 128). Diens dochter Marie Antoinette Georgette de Serière trouwde 15 Aug. 1834 te Poerwakarta met John Pitcairn, den stichter der firma Pitcairn Syme en Co.

Servatius (Willem Nicolaas) van Koevorden, zoon van Joan Petrus S. en Gerhardina Fockelina Engelhard, geboren 1785, op Java gekomen October 1804, trouwt 23 Nov. 1813 Sara Catharina Senn van Basel, dochter van Mr. Willem Adriaan Senn van Basel, Raad Extraordinair van Indië, en Jacoba Theod. van Riemsdijk (zij is eene volle zuster van Baud's vrouw); is dus, behalve een oomzegger van N. Engelhard, ook geparenteerd aan de Van Riemsdijken; hertrouwt 4 Sept. 1815 met Catharina Elis. Couperus, weduwe van Dr. Johan August van Kerst (overl. 1814), dochter van Abraham Couperus, geb. te Tranquebar 1798, overl. te Banjoemaas 1864.

Hij was bij de verovering Secretaris te Solo (2e Resident aldaar 1808-1811); de Soenan klaagde zeer over hem en drong op zijne verwijdering aan, die dan ook weldra plaats vond. Woont daarna als eigenaar op het Buitenzorgsche land Kampongbaroe. Nam bij de teruggave Cheribon over van Hanson. Overleed 1827 insolvent als Resident der Preanger. Zie nog Van der Kemp, Herstel p. 274. 
Scton (A.), een Schot, eerst Resident te Delhi, daarna Governor of Penang, ging met Minto naar Java; is Sept. 1811 te Bat. en doet in dat najaar eene reis over Javs. Trad 23 Dec. 1812 op als Member of Council te Calcutta.

Scvenhoven (Jan Izaak van; hij teekent zich echter I. J.), geb. te Amsterdam 1782, kwam 11 April 1803 op Java, werd klerk bij Schepenen, trouwde Jan. 1805 met Catharina Arnoldina Mom, oud 15 jaar, dochter van wijlen den Raad Ord. van Indië A. C. Mom en Catharina Louise van Riemsdijk, zoodat hij het in 8 jaar bracht tot Secretaris der H. Regeering. Maar de Mom's en Riemsdijken waren tevens Franschgezind, en dus kostte de verovering van Java onzen vriend zijne betrekking; toen hij in Sept. 1812 van Samarang naar Bat. reisde, kregen de Residenten langs zijn weg den last om hem scherp in de gaten te houden en aanrakingen van hem met de Regenten te beletten. Hij woonde toen op zijn land aan de Sontar. Gaandeweg makte hij eene zwenking: op den feestdag 24 Aug. 1814 ter eere van Nederlands herstel hield hij de feestrede in het Bat. Genootschap en werd Proc. 12 Sept. 1815 tot Fiscaal van het Supreme Court benoemd, wat hij bij de teruggave nog was; hij had toen 880 Java Roep. p.m. Een ontwikkeld en intelligent dikzak. Hertrouwde 21 Juli 1816 met Jacoba Maria Goldman, weduwe Barrett. Cranssen oordeelt Proc. 17 Nov. 1815, dat hij zich ambtshalve met zaken bemoeit die hem niet aangaan. Later Resident en (tegelijk met zijn schoonvader) Raad van Indië. In 1826 wordt over Van Sevenhoven als Resident van Cheribon geschreven (Roorda van Eysinga, Verschillende reizen III, 68), dat hij ,als menschenvriend door iederen Europeaan en inlander bemind” wordt, ook om ,zijn gelukkig voorkomen en opregten, gullen lach". Hij overleed 13 Maart 1841 op terugreis naar Indië, oud 58 jaar, en werd te Bat. begraven.

Scvestre (Sir Thomas), Assistant Surgeon, had, volgens eene mededeeling in Gaz. 7 Maart 1812, in 1810 van den Prince Regent van Portugal de orde van het Kasteel en het $Z$ waard gekregen wegens bewezen diensten als chirurgijn op een Eng. oorlogsschip. Bij Gen. Orders van 13 Febr. 1812 werd hij belast met the general medical duties of the district of Buitenz. op 250 Sonat Roep. p. m. van af 1 Dec. 1811. Van 21 Juli tot 1 Sept. 1812 was hij te Djokja chef van het veldhospitaal, en werd 26 Nov. 1812 geplaatst te Samar. als garnizoensdokter en chef van het vrouwenhospitaal. Als zoodanig liet 
hij een paard meedraven bij de Salatiga races in Oct. 1812, en werd hij in Dec. 1813 vervangen door Raffles' zwager Campbell Brown, die hem eerst te Buitenzorg had opgevolgd. Het heette nu, dat S. naar Madras zou terugkeeren (Gaz. 18 Dec. 1813), en dat kan ook wel gebeurd zijn, maar Gaz. Extrao. 13 April 1814 werd hij opnieuw te Buitenzorg geplaatst en Proc. 30 Juni 1814 vinden wij hem daar zelfs als Assistant for the Separate Department werkzaam op de Secretarie op 300 Java Roep. Hij woonde volgens Addison, die hem een origineel noemt, ten huize van Raffles, blijkbaar als diens lijfarts; hij geeft dezen dan ook 28 Sept. 1815 een certificaat, dat hij wegens eene leverkwaal eene zeereis moet doen. Bij Gen. Orders van 25 Nov. 1815 werd zijne betrekking van Medical Officer at Buitenz. opgeheven; hij zou echter p. m. 100 Sonat R. trekken voor medische hulp aan het personeel aldaar, doch werd tevens benoemd tot Superintendent of Vaccination in the town and suburbs of Bat. op 300 Sonat Roep.; bij Proc. 1 Dec. 1815 werd hij voorts benoemd tot Civil surgeon for the town of Bat. op 400 Roep. Toen Raffles aftrad en niet naar Benkoelen wenschte te gaan maar naar Europa, gaf S. hem een certificaat (Proc. 15 Maart 1816), waarbij hij verklaarde, sedert verscheiden jaren den Lieut. Gov. te hebben behandeld en kennis te dragen van zijne leverziekte, welke thans eene reis naar de Kaap and eventually to Europe noodig maakte; waarop besloten werd, dat S. zijn patient zou begeleiden. Dit laatste werd door Directeuren zeer euvel opgenomen (Egerton p. 129; Widow p. 272).

Vermoedelijk was 's mans adellijke titel bij Raffles eene niet geringe aanbeveling. Althans Doctor Raffles ging er niet weinig trotsch op, dat zijn neef een Baronet tot lijfarts had (Boulger p. 257).

Shrapnell $(J$.$) komt als handelaar met vergunning van het Bom-$ bay Govt. met de veroveringsexpeditie op Java; helpt Proc. 16 April 1812 de Regeer. in haren strijd over het opium met het Opperbestuur; wordt Gaz. 25 April 1812 benoemd tot Magistrate for the City and Environs of Bat. op een goed salaris. Proc. 22 Juli 1812 bovendien aangewezen als Gouv. Commissionnair met een minimum inkomen van 400 \$. Geeft Gaz. 13 Febr. 1813 met Philip Skelton kennis van de oprichting der firma Shrapnell and Co. (Forbes and Co. te Bombay waren bij deze firma geinteresseerd) en in die van 12 Febr. 1814 van de toetreding van J. Davidson, waardoor de firmanaam wordt Shrapnell, Skelton and Co. Nog in Proc. 8 Juni 1814 heet Shrapnell agent van Forbes en Co. Overlijdt 20 Jan. 1815, 
waarna de naam wordt Skelton and Co., Gaz. 18 Febr. 1815. Dit sterfgeval gaf aanleiding tot eene belangwekkende discussie, in hoever de Weeskamer zich thans met de zaken der firma had in te laten; ten slotte werd W. Robinson, die deliberatief lid der Weeskamer was, in de firma toegelaten als joint agent or curator der zaken van Shrapnell (Proc. 13 Maart 1815), waardoor dus de zaken der firma aan de kennisneming van het college werden onttrokken. Na Robinson's overlijden liet de Regeer. bij Proc. 27 Oct. 1815 de verdere afwikkeling der zaak aan de Weeskamer zelve over. In 1819 wordt D. A. Fraser opgenomen in Skelton en Co.

Smissaert (A.H.), geb. te Batavia, doch (naar 't schijnt) in Nederland opgevoed en in Nov. 1802 op Java teruggekomen, is in 1804 de schoonzoon van den Kassier van den Generalen Ontvang Cornelis Eekhout (de vrouw is al dood); huwde Clara Elis. von Liebeherr, dochter van B. F. von Liebeherr (overl. 1821 te Bat. als Superintendent van het Vendukantoor); was bij de verovering President van het college van administratie der Houtbosschen; 1 Dec. 1811 gaf hij zijn archief over aan Flint. In Dec. 1811 is hij President van het gerechtshof te Samarang; gaf er in April 1812 een feest, waarvan eene ironische beschrijving staat in Gaz. 2 Mei 1812, 4. Bij publicatie van 21 Jan. 1812 werd hij benoemd tot Magistrate te Samar. en President van het Court of Requests aldaar; Proc. 15 Sept. 1812 werd hij benoemd tot lid der commissie voor den landverkoop aldaar. In Oct. van dat jaar ging hij naar Bat. en werd Gaz. 14 Nov. 1812; benoemd tot Magistrate of the Environs op 350 \$ (hij ruilde dus met De Salis); als zoodanig heet hij ook Baljuw der Ommelanden; zijn salaris werd bij Proc. 9 Febr. 1813 verhoogd tot 400 \$. Hij woonde op Molenvliet; in zijn huis gaven Assey en anderen 19 Nov. 1813 een bal; ook was hij eigenaar van Soedimara. Proc. 2 April 1814 werd hij benoend tot lid van het Supreme Court en Circuit Judge in the Western Division op zijn tegenwoordig salaris; den 20 April droeg hij zijn werk over aan W. Ainslie, die Resident der Ommel. heette. Proc. 30 Juni 1814 is zijn salaris 880 Java Roep. Hij bleef deze betrekking bekleeden tot de teruggave, toen hij Resid. van Rembang werd (Van der Kemp, N.-I. Bestuur p. 21). Later bekend als Resident van Djokja. Schijnt zonderlinge opvattingen te hebhen gehuldigd, want Raffles achtte zich verplicht, hem bij schrijven van 25 Sept. 1812 te beduiden, dat hij als Magistrate te Samarang geen aandeel mocht hebben in de boompacht aldaar, omdat hij niet 
als rechter kon zitten over zaken, waarbij hij persoonlijk belang had.

Een Balthasar Smissaert werd Proc. 23 Nov. 1811 President der Weeskamer te Batavia en overleed als zoodanig 2 April 1813; woonde op den hoek der Kalverstraat (Gaz. 19 Juni 1813); volgens Campbell I, 434 was Balthasar een oom van Anthony Hendrik S.

Smith (J.F.), een Hollander, oud-Kolonel, thans Boschganger, wordt bij schrijven van 8 Juli 1815 geplaatst in Toeban als Assistant van den Resident, meer speciaal belast met de ,general superintendance over the police etc.”, terwijl zijn salaris wordt gebracht op 400 Java Roep.

Soady (T. Eales), Ensign Sixth Bengal Volunteer Battalion, diende 1815 bij het Javanese corps. Zie onder: De Waal.

Steenbrugge $(P$.$) , oud leerling der Sam. Marineschool, was bij de$ verovering Opziener van Soekapoera; bevestigd als Opz. 2e klas aldaar op $75 \$ 2$ April 1812. Overlijdt 9 Febr. 1814.

Stopford (R.), Rear Admiral of the Red and Commander in Chief in the East Indies tijdens de expeditie. Minto schrijft 2 Sept. 1811, dat S. arrived from his station at the Cape of Good Hope and took the command of the Indian squadron serving against Java, nadat de maatregelen voor de expeditie reeds waren genomen. Zijne vlag woei op de Scipion. Hij was door Straat Bali aan de noordkust gekomen en voegde zich eerst den 9 Aug. 1811, dus na de landing te Tjilintjing en de bezetting van Bat., bij de expeditie, waardoor hij Commodore Broughton supersedeerde, die aan Minto zooveel ergernis had gegeven. Het was hem daarbij te doen ,om deel aan den buit”, zooals Prior vertelt, die zelf onder Stopford diende (Reis p. 155). Deze zeeheld is pas in 1847 te Richmond overleden in den ouderdom van 80 jaar.

Supper (J. C.) van Göppingen in Wurttemberg, tot zendeling opgeleid te Berlijn, Rotterdam en in Engeland, kwam in het voorjaar van 1814 uit Europa; wordt 20 Aug. 1814 geplaatst te Bat. als Predikant der Herv. gemeente en vervanger van den naar Malakka vertrokken Cluver, op 440 Java Roep. Deed ook dienst in de Luthersche kerk. Uit Boulger p. 183 blijkt, dat hij door bemiddeling van Raffles' neef Dr. Raffles, die a Director of the Missionary Society 
was (ib. p. 188), met nog een ander als zendeling naar Java was gezonden (die ander schijnt Trowt geweest te zijn). Raffles noemt hem a good simple creature, rather silly. Trouwde 9 Juli 1815, natuurlijk met eene weduwe, geene rijke weduwe echter, want hij woonde maar in de Koestraat; overleed al einde 1816 als Predikant der Maleische en Portugeesche gemeente. Zijne vrouw heette S. C. van der Plaats.

Taylor (Edward), Lieutenant H. M. 8th Light Dragoons, wordt Proc. 21 Oct. 1814 benoemd tot Assistant to the Resid. at Djocjocarta; hij kwam aldaar eerst begin Dec. 1814 aan; den 31 Aug. 1815 geeft Garnham de residentie aan hem over, die hij 1 Nov. weder aan D. Ainslie overgeeft. Bleef aldaar Ass.-Res. tot de teruggave.

Een Lieutenant Taylor 25th Drag. is volgens Directory 1814 Aidede-camp van Raffles.

Teylingen (Pieter Isaac van), geboren 1790 op Ceilon, was de zoon van Theodoor van Teylingen (die in 1801 repatriëerde als OudResident van Tegal, maar in 1806 op Java terug was) en E. C. Schröter (denkelijk eene dochter van C. F. Schröter, die in 1800 Predikant te Colombo was). Uit dit huwelijk waren 15 kinderen, maar de familie was geparenteerd aan $\mathrm{Mr}$. Isaac van Teylingen, Burgemeester van Rotterdam en Bewindhebber der O.-I. Compagnie, die in 1787 samen met Van der Heim en anderen als Prinsgezinden cloor de Patriotten uit de Vroedschap van Rotterdam werd gezet, zoodat de Van Teylingen's later, toen Van der Heim onder Koning Lodewijk tot Minister van Koloniën was benoemd, op diens steun konden rekenen (vergelijk Dr. de Roo I, 99 noot 1). Aldus werd E. C. Schröter, thans weduwe, door Daendels den 2 Febr. 1810 op 2.000 Rds. zilver per jaar benoemd tot intendante van Bodjong. Onder Raffles had zij 120 \$ p.m. en bleef dit bedrag als pensioen trekken, nadat zij in 1813 op verzoek was ontslagen, omdat het haar op Bodjong te druk was. Zij overleed te Samarang 11 Jan. 1825.

De zoon was einde 1810 Gezworen klerk bij het Kabinet van den G.-G.; werd bij besluit van 1 Nov. 1811 klerk op de Secretarie; Proc. 1 Dec. 1812 lid van het Court of Requests te Samarang; door Hope 26 Juli 1813 op 75 \$ benoemd tot Assistant van den Resid. van Djipan, hetgeen Proc. 13 Aug. 1813 wordt bevestigd (alwaar verkeerdelijk van Djapan wordt gesproken). Als zoodanig nam hij na de opheffing der residentie Djipan en Grobogan, den 3 Sept. 
1815 deze afdeeling over van Eckford en trad op als waarnemend Resident, tot Djipan bij beschikking van 6 Jan. 1816 bij Rembang werd gevoegd en hij weer Assistant werd, thans aan den Resident van Rembang ondergeschikt. Van Waeij diende te Bowerno onder hem en vertelt, dat hij trouwde met ,de freule von Winkelmann”, hetgeen bevestigd wordt door Gaz. 16 Maart 1816: het huwelijk met C. J. J. von Winckelmann, oudste dochter van F. von W. (zie aldaar), had plaats te Rembang. Zij overleed reeds 30 Dec. 1816, oud 17 jaar, en hij 4 Juni 1819 te Samarang. Den 1 Mei 1816 had hij Djipan overgegeven aan W. Davies, na ontslag uit den dienst te hebben gevraagd.

Een D. G. van Teylingen, die in 1815 Second Assistant was van Eckford, was een jongere broer. Deze trouwt 19 April 1824 te Djokja met Cecilia Johanna Beillard. Hij wordt Resident van Kediri 1838. Eene zuster, Cornelia Wilhelmina Frederika, geboren te Jafnapatnam, trouwde 4 Oct. 1806 te Bat. met Joh. Henr. van IJsseldijk van Djokja, zoon van W. H. van IJsseldijk.

Tency (P.), biographie in Priangan I, 112 e.v.; bij de verovering gewezen Gecommitteerde over de Bovenlanden, wordt 23 Nov. 1811 benoemd tot Commissaris van Bandoeng (d.i. de regentschappen Soemedang, Parakanmoentjang, Limbangan, Soekapoera, Galoeh en Bandoeng) en 25 Nov. 1811 bovendien op 200 \$ tot Inspecteur Generaal over de koffiecultuur in de Batav. Regentschappen. Overleed 8 Sept. 1812.

Terreneau (R.) wordt 1 Juni 1816 benoemd tot English Fiscal of the Supreme Court of Justice, terwijl Van Sevenhoven dus Dutch Fiscal moet zijn gebleven.

Thorn $(W$.$) , Captain der Dragonders, daarna Major, schrijver van$ een werk over de verovering van Java en van eene biographie van Gillespie; neemt deel aan de bestorming van Meester Cornelis; wordt bij General Orders van 29 Sept. 1811 benoemd tot Deputy Quarter Master General; wordt belast met den aanleg der telegraaf van Weltevreden naar Buitenzorg (Proc. 7 Dec. 1811; Gaz. 2 Maart 1812); neemt deel aan de expeditie naar Palembang (Gaz. 30 Mei 1812; Widow p. 114; 116; Conquest p. 134; 168) en die tegen Djokja (Gaz. 4 Juli 1812; Conquest p. 180; 195). Hij deed eene reis over Java (den 14 Aug. 1812 kwam hij van Samar. over zee te Bat. terug), 
die hij later tijdens een verblijf op Sint-Helena uitwerkte (Conquest p. XIV). Hij verliet het eiland reeds 4 Juli 1813 om naar Europa terug te keeren. Een weinig beduidend persoon en als schrijver niet bovenmate betrouwbaar; zoo zijn de platen in zijne History voor een deel oude platen van Rach, verrijkt met Britsche vlaggen (Campbell heeft die platen in zijn boek gretig overgenomen); de KapteinChinees, wiens begrafenis er ook in afgebeeld staat ,as drawn on the spot", was al in 1784 overleden.

Timmerman Thijssen (Jan Samuel), geb. 1782; trouwt Henr. Elis. Meijer, overl. te Kopenhagen 23 Oct. 1806; kwam van Malakka op Java 8 April 1810; hertrouwde met Gesina Couperus, dochter van Abr. Couperus, geb. te Malakka 1785, overl. te Batavia 10 Sept. 1828, wier eerste man was Johan Hendrik Meijer, overl. 1808.

Wordt bij publicatie van 21 Jan. 1812 Member of the Bench of Magistrates te Bat. Komt reeds Proc. 10 Oct. 1812 voor als Second Magistrate te Bat. op 250 \$, 28 Mei 1813 idem op 200; blijft Member tot 1816. Was eigenaar van het landgoed Kampong Malajoe; geeft aldaar een bal ter eere van Sir Samuel Hood, Gaz. 30 Juli 1814. Is 1813-1815 chef van het huis Timmerman Thijssen en Westermann (B. W. Westermann van Kopenhagen), blijkens Proc. 24 Nov. 1813 agenten van Palmer en Co. te Calcutta, welke firma Proc. 28 Oct. 1814 schrijft, dat naar haar idee T. Thijssen en Co. te veel onder den invloed van het Gouv. staan.

Bij brief van 28 Mei 1814 geeft het Opperbestuur Raffles eene berisping over eene voor T. Thijssen en Westermann zeer voordeelige transactie betreffende den inkoop v. opium, te betalen met Gouv. koffie. Bij Proc. 8 Juni 1814 krijgt het huis T. Th. en Westermann uit 's Lands kas een renteloos voorschot voor 6 maanden, groot $30.000 \$$ ! Het huis werd met 1 Juli 1815 ontbonden. In den halfyearly almanac for 1815 komt het nog voor op de lijst van handelshuizen; in den almanak voor 1816 niet. Bij Proc. 3 Maart 1815 kreeg hij als Magistrate 6 maanden verlof to proceed to India on account of his health; bij een besluit van 28 Aug. 1815 werd bepaald, dat T. T. will resume his duties as Magistrate from the 1 st proximo.

Deze heer was misschien onder al de pluimstrijkende Batavianen van destijds de strooperigste. Een kind van hem, geb. 15 Juli 1813 te Batavia, wordt 15 Sept. gedoopt, natuurlijk met den naam van Mevrouw Raffles. Op het „,nationale” feest van 24 Aug. 1814 ter eere van de onafhankelijkheidsverklaring van Nederl. zegt hij ,that the 
most fortunate moment which Java had ever known was that, on which Lord Minto selected Mr. Raffles for its future Governor". Omtrent Minto beweert deze platte Hollander (Gaz. Extrao. 23 April 1814): „His Sovereign has conferred on him the dignity of an Earl, but the Almighty has recorded his name in the Annals of Philanthropy (eene astraal periodiek) and at a future period we (nogal voorbarig van Samuel) may expect to behold our Noble Benefactor in the Mansions of Heaven decorated with the emblems of sincerity and virtue (Commandeur van den Hemelschen Leeuw, virtus beatificat). In eigenaardige harmonie met dit geflikflooi is Timmerman's zonderlinge transactie met de Weeskamer, die anno 1812 hem 5.000 \$ zilver leende, welke hij met behulp van den knoeienden President Meijer kon terugbetalen in gedeprecieerd papier, a pari berekend.

Door C. C. G. G. 1818 benoemd tot Commissaris voor de overname van Malakka; wordt datzelfde jaar Gouverneur van Malakka. Zeer ongunstig oordeel van Abdullah over. T. T.'s bestuur te Malakka, waar hij 14 Jan. 1823 in die functie insolvent overleed, bij Thomson, Translations from the Hakayit Abdullah bl. 118.

Travers (Thomas Otho), Lieutenant Bengal Native Infantry, wordt bij General Orders 13 Febr. 1812 benoemd tot Assistant Secretary to Government in the Military Departm. op 200 \$. Raffles had hem reeds in 1806 te Penang ontmoet (Widow p. 6). Ging 1812 als Commissary op 400 Son. Roep. p. m. met de expeditie naar Palembang (Gaz. 3 Aug. 1812) en wordt Gaz. 22 Aug. 1812 benoemd tot Town-Major van Batavia, ter vervanging van Meares, nadat hij Raffles als Ass. Secr. begeleid had tijdens de expeditie tegen Djokja. Naar aanleiding van Gillespie's beschuldigingen tegen Raffles, wiens Aide-de-camp hij was, werd T. in 1814 met depêches naar Europa gezonden (Widow p. 211); hij vertrekt 29 Maart van Bat.; komt 11 April te Soerabaja; 20 Juni aan de Kaap; vertrok vandaar 2 Juli. Hij was 1 Dec. 1814 te Londen (Van der Kemp, Herstel p. 38) en einde December in den Haag (id. Teruggave p. 191); komt 31 Juli 1815 met Flint en John Scott (wiens schip de Isabella voor de heenen terugreis had gediend) te Bat. en treedt weer op als Town-Major, terwijl hem tevens het commando over het Amboynese corps wordt opgedragen (Gaz. 19 Aug. 1815); als Town-Major erlangt hij 22 Aug. 1815 eene extra toelage van 300 Java Roep. per maand. Bij Raffles' reis naar de Vorstenlanden in Jan. 1816 ging T. weer mee

D1. 92. 
als Aide-de-camp. Toen Raffles zou heengaan, kreeg T. bij Gen. Orders van 22 Maart 1816 verlof om naar Europa terug te keeren, en samen deden zij de reis (Widow p. 272). In 1818 en 1819 vinden we hem bij Raffles te Benkoelen (Bijdr. 1897 p. 379; 1900 p. 588) en in 1820 werd hij Resident van Singapore (Widow p. 446). Hij heeft een Journal geschreven (Egerton p. 73).

Trowt (Thomas), zendeling, komt met zijne vrouw uit Engeland te Bat. 16 Sept. 1814; woont Jan. 1815 te Weltevreden, bezig met Maleisch te leeren; schrijft 27 Maart 1815, dat hij verlangt to reside at Samarang for the purpose of acquiring the Javanese language; dit wordt toegestaan en Raffles zegt in zijne Discourse van 11 Sept. 1815 (Verh. B. G. VIII p. 43 noot), dat T. is prosecuting his studies at Samar. with great success (in een particulieren brief daarentegen van Febr. 1815 had het geheeten dat T. is not doing much, Boulger p. 188). Bij een schrijven van April 1816 beval R. hem nog aan Fendall aan, evenals zijn plan om eene opleidingsschool voor inl. ambtenaren te Samar. te openen. Overleed volgens Van Troostenburg de Bruijn reeds in Oct. 1816.

Tucker $(W$.$) , Lieutenant, wordt bij Gen. Orders van 29$ Sept. 1811 benoemd tot Assistant Paymaster General. Wij vermelden dit enkel om het hooge traktement dat hij in April 1814 blijkt te ontvangen, namelijk 2.450 Sonat Roep. p. m., waarvan echter voor personeel 937 afging. Een Henry St. George Tucker was destijds Secretary to the Supreme Govt. te Calcutta.

Veeckens (Lambertus Zegers), biographie in Priangan I, 114 e.v. Bij de verovering van Java was hij Landdrost der Batav. Regentschappen. Werd 4 Sept. 1811 als zoodanig ontslagen (hij beweerde later, vrijwillig den dienst te hebben verlaten, zie Van der Kemp, Ned.-Ind. Bestuur p. 349). Als Daendeliaan bleef hij tijdens het Eng. bestuur buiten betrekking. Door zijn huwelijk met Cath. Charlotte Holle was hij schatrijk. Tijdens Daendels had hij het Krawangsche land Tjabangboengin gekocht, waarvan hij ,,de inkomsten” van verschillenden aard te huur aanbiedt in Gaz. 24 Oct. 1812. Ook bezat hij een ,tuin" aan het strand bij Tandjoengpriok.

Zijn broer Hendrik Veeckens, tijdens Daendels Secretaris-Generaal, overleed 28 Nov. 1815; deze woonde op Grogol en was met J. Tiedeman eigenaar van de landen Djengot en Pasilian; trouwde 10 Aug. 1805 met Geertr. Corn. Stokkie van Batavia. 
Veeris (P.) van Amsterdam, 6 Aug. 1793 aangekomen, was bij de verovering Landdrost van Tegal; verloor deze betrekking, toen Tegal met Cheribon werd vereenigd (eind Oct. of begin Nov. 1811), doch werd reeds bij publicatie van 21 Jan. 1812 benoemd tot Member of the Bench of Magistrates te Bat. In Oct. 1812 is hij First Magistrate op 300 \$, in 1813 op 250 \$, in 1814 op 550 Java Roep. Overlijdt 29 Juni 1817 als Superintendent van het Zout-Departement.

Verhage (Wouter), gewezen leerling der Samarangsche Marineschool, neemt 1798 een Engelsch schip; woonde 1803 te Soerabaja als oud-Capitain ter zee titulair; werd 1805 Equipage-opzichter te Samarang; 1809 Havenmeester te Rembang. Nadat Daendels den 22 Juni 1810 (zie Ned.-Ind. Plakaatboek XVI, 235) had toegestaan om voor den scheepsbouw desa's en bosschen in de Vorstenlanden te huren, maakte $\mathrm{V}$. daarvan gebruik voor het huren van een perceel bij Telong aan de Solorivier, om de opgezetenen hout te doen kappen in de nabijgelegen bosschen en dit naar Telong te vervoeren. Hij schijnt van het Ned. bestuur ook vergunning te hebben erlangd, om zijne vaartuigen te Grissee te verkoopen zonder de gebruikelijke belasting daarbij te voldoen. Telong was de toenmalige hoofdplaats van het district Tinawoen, dat in 1812 aan het Gouv. kwam. Bij schrijven aan Hope van 25 Sept. 1812 staat Raffles toe, dat Verhage voorloopig met zijne onderneming doorgaat, zoodat Hope den 13 Oct. 1812 Verhage daartoe machtigde. Volgens Van Waeij bouwde hij zijne prauwen op het land en bracht ze in Jan. of Febr. bij overstrooming in de rivier.

Hopkins schrijft 9 April 1813, dat the general prohibition of cutting teak timber has been lately extended to Mr. Verhagen; het grootste door hem gebouwde schip is een padoewakan van 70 voet; bovendien bouwde hij per jaar ongeveer 50 prauw majangs; voor een van 3 kojan, waaraan echter heel geen ijzer is, rekent hij maar 45 \$; Hopkins vindt zijne werf een gevaar voor de bosschen van Padangan; die werf bewijst zijn ijver en bekwaamheid en er is nogal kapitaal in gestoken; Hopkins stelt voor, hem prauw majangs voor het Gouv. te laten bouwen; hij laat bouwen bij aanneming, 10 \$ werkloon per prauw; om de Gouv. werf te Rembang te ontlasten, stelt Hopkins nu voor, een zeker aantal prauwen door Verhage te laten bouwen, tegen 10 \$ maakloon en eene vergoeding voor zijne leiding en het gebruik van zijne werf; het hout kan hij krijgen uit den afval van grootere boomen en uit overigens ongeschikte balken; 
die prauwen kunnen dan te Grissee rijst laden voor Bat. Daarop wordt Proc. 14 Mei 1813 besloten, om door V. 50 booten te laten bouwen, en Hopkins daartoe een contract met hem te laten sluiten. Den 10 Juni 1813 schrijft Hopkins: Verhage is bereid 50 prauwen te bouwen benevens 12 sampans elk voor 25 kojans op de reede van Bat., de eene helft klaar op 15 Sept., de andere helft op 15 Oct.; hij vraagt voor een 3 kojans prauw met zeil en treil 29 \$ (sic); voor een 25 kojans sampan dito dito 208 \$; het Gouv. levert daartoe het hout en het ijzer; Shrapnell heeft hem voor zulke sampans $600 \$$ geboden. Bij Proc. 23 Juni 1813 neemt de Regeer. dit voorstel aan wat de prauwen betreft, maar zwijgt van de sampans. Maar de brief der Regeer. van 24 Juni aan Hope spreekt daar wel van; in den prijs is het ijzer niet begrepen, zegt zij, en evenmin het hout.

Den 2 Maart 1814 schrijft V. zelf, dat hij volgens contract aan het Gouv. zou leveren 50 prauw majang's van 3 kojan en 12 houtsampans; dat van de eerstgenoemde er 25 gereed zijn, echter van 5 à 6 kojan! In Sept. 1815 werd er nog aan zijne werf gearbeid, doch zijne voordeelen waren grootendeels verdwenen, want $15 \mathrm{Mei}$ 1814 had de Regeering gelast om de afdeeling Tinawoen, waar Verhage's werf is, evenals andere landen in de landrente aan te slaan, waarvan zij, naar het schijnt, tot dusver verschoond was gebleven. Maar 20 Juni 1814 schrijft zij, dat zij niet ongeneigd is hem toe te staan om door zijn eigen volk hout te laten kappen in een boschperceel, aan te wijzen door den Superintendent of Teak Forests, tegen betaling van den houtprijs, vastgesteld bij publicatie van 21 Febr. 1814 en onder voorwaarde, dat er goed op het kappen wordt toegezien.

In Sept. 1815 klaagt hij weer dat hij, na de inlijving van Djipan (waartoe Tinawoen destijds behoorde) bij Rembang (feitelijk had deze inlijving toen nog niet plaats gehad), zijn hout alleen op de Gouv. stapelplaatsen kan koopen, terwijl hij tot dusver enkel betaalde 10 percent of each vessel constructed by him (met, naar 't schijnt, den vrijen houtkap).

Zóó druk was zijn werk echter nooit geweest, of hij was sedert 15 Sept. 1813 tevens te Sidajoe Zoutpakhuismeester geweest op 100 Java Roep. In 1817 werd hij Kapitein Luitenant en Directeur van 's Lands werf te Boenga (aan de Solorivier, niet ver van hare monding). Zij werd opgeheven in 1826.

In 1827 woont W. Verhage te Grissee. In 1828 heeft hij weer eene werf te Boenga aan de Solorivier. In 1836 dito; hij leeft dan 
nog te Grissee. Zijne vrouw was M. C. W. Scheitman. Verhage overlijdt te Grissee 8 Febr. 1838, oud 68 jaar, als gep. Kapitein ter Zee.

Verster $(F$.$) , bij de verovering Drost der Ommelanden, daarna$ Baljuw der stad Bat., overlijdt eind Nov. of begin Dec. 1811. De weduwe Christiana Wilhelm. Elis. van Teylingen hertrouwde met G. F. Meylan; zij overleed in 1819 te Tegal.

Villarrubi (Sebastian), geb. te Calderas in Catalonië, Kapitein der jagers te Manila (hij sprak gebrekkig Engelsch), komt 25 Oct. 1810 te Batavia voor als doopgetuige (was dus wellicht een Engelsch spion); was in Sept. 1811 de leider van eene bende Inlanders, die te Sidajoe eene Hollandsche brik plunderden (Proc. 14 Oct. 1814). Volgens Gibbs werd V. destijds door Captain Harris (zie aldaar) gebruikt als chef eener bende Madoereezen, en scheen hij te zijn geweest the instigator to the excesses and irregularities which took place, zoodat de Regenten were in a very slight degree implicated in the guilt. In 1812 ging hij als Maleische tolk met de expeditie naar Palembang (Widow p. 116) en was een der handvol menschen, waarmee Gillespie den kraton binnentrok (Conquest p. 140). Daarna bleef hij te Palemb. als agent of supplies for the garrison of Minto, maakte zich als zoodanig verdienstelijk, doch verloor die betrekking op 1 Sept. 1812 en werd vervolgens in arrest gesteld op beschuldiging een Inlander te hebben vermoord. Na zeer lange deliberaties of hij voor een Krijgsraad zou komen, zooals Gillespie wilde, of voor den burgerlijken rechter, zooals Nightingall best vond, werd Proc. 1 Nov. 1813 besloten, hem voor het Supreme Court te recht te stellen. Hij werd vrijgesproken (Gaz. 9 April 1814), doch eenige weken later opnieuw gearresteerd wegens correspondentie met den afgezetten Sultan van Palembang (Proc. 13 Mei 1814). Of deze vervolging soms kan samenhangen met de even opmerkelijke actie tegen Robison (volgens Proc. 17 Sept. 1813 was een geschenk van den Oud-Sultan voor Robison door V.'s handen gegaan), is mij niet bekend. In afwachting zijner opzending naar Europa werd V. in de gevangenis der Magistrates van Bat. op het Stadhuis gezet; zijn verzoek om wegens ziekte uit dezen ongezonden kerker te worden gelaten, werd 10 Juni 1814 afgeslagen met de snedige opmerking, dat hij daar geneeskundige hulp had en al aan de beterhand was, waarop V. de onhebbelijkheid had, den 17 Juli 1814 in het hospitaal zijn laatsten adem uit te blazen. 
Villeneuve (Louis François Joseph), geb. te Lille, kwam in Sept. 1793 op Java met de Fransche expeditie onder D'Entrecasteaux, en wel in qualiteit van domestique; trad wellicht in dienst van den Gouverneur te Samarang, althans hier woonde hij in 1806; hij trad daar echter ook op als pachter van de Stadsherberg; werd door Daendels 2 Febr. 1810 benoemd tot Intendant van het paleis te Buitenz. op eene jaarwedde van 2.000 Rds. en met den rang van Kapitein; komt ook voor als Aide-de-camp van Daendels; neemt als Kapitein bij den staf van Daendels deel aan de expeditie tegen Djokja in 1810. $\mathrm{Na}$ den val van Meester Cornelis maakte hij zich verdienstelijk door het paleis te Buitenzorg te beschermen tegen vernieling en plundering. Ook onder Raffles bleef hij Intendant, en wist zijn jasje zoo goed te keeren, dat hij 10 Mei 1812 een dochtertje liet doopen met de namen van het hooge echtpaar, Olivia Mariamne Stamford Raffles Villeneuve. In Dec. 1812 kocht hij de beide Gouvernementshuizen op Goenoengsari, waarvan hij een hotel wilde maken. Ook nadat hij Gaz. 23 Mei 1812 was benoemd tot Assistant to the Landdrost of Buitenz. op 150 \$ (hij heet ook wel Deputy Landdrost), bleef hij Intendant. Bij acte Piepers 26 Maart 1813 no. 1708 kocht hij van A. W. L. van Gesseler te Lintelo het land Majoran, dat vroeger aan Zimmer had behoord, met de daarbij behoorende slaven, paarden, rijtuigen enz. en vroeg daarop ontslag als Assistant Resident, hetwelk 12 April werd verleend. Hij werd nu postondernemer, doch verloor reeds het eerste jaar 300 paarden aan eene epidemie en in 1814 nogmaals 66; ook klaagde hij bitter over de gebleken schade bij zijn contract met het Gouvt. De Regeer. liet hem echter in zijne schulden zitten (Proc. 28 Oct. 1814), zoodat hij failliet ging en zijne eigendommen op Goenoengsari onder den hamer kwamen (Gaz. 24 Dec. 1814). Blijkens Proc. 1 Dec. 1815 had de Weeskamer eene hypotheek van Java Roep. 74.123 op hem met achterstallige interest ten bedrage van nog 8.616. Hij overleed, 57 jaar oud, op 6 Dec. 1815 ; zijne weduwe Johanna Emilia Gewiss was de eigenaresse van het in de Gaz. van 24 Febr. 1816 te koop geboden land Majoran ,met dies ruime huizinge", met ,stallingen voor ruim twee honderd paarden, wagenhuizen, smederijen en verdere ap- en dependentien mitsgaders twee privilegien van wagenverhuurderijen benevens alles wat tot de posterij van hier naar Buitenzorg behoort". Het einde van het lied was, dat Commissarissen-Generaal van de Eng. Regeering eene pretentie op zijn boedel overnamen groot Java Roep. 24.658. 
De weduwe bleef hotelhoudster; bij haar trok Van de Graaff in (Brieven II, 8).

Wat aangaat genoemd land, den 27 Nov. 1807 had de Regeer. aan Zimmer toegestaan om eene door hem gekochte wagenverhuurderij te verplaatsen naar zijn land Kemajoran.

Bij acte Piepers 29 April 1812 no. 721 verkoopt Zimmer aan A. W. L. van Gesseler te Lintelo het heele land Majoran met opstallen, twee privilegiën van wagenverhuurderij, 65 slaven (koetsiers, stalknechts, smids enz.), 87 span paarden met tuigen, 29 wagens met gereedschap, nog 55 slaven en slavinnen, waaronder ,een stel musikanten”, 10 wagens, phaetons enz., 120 span paarden ,waaronder zoo veel spannen van vieren als tot de zeven stations tusschen Batavia en Buitenzorg nodig zijn, plaatsende op elk station vijf span van vieren"; verder allerlei materialen voor reparatie van wagens, meubelen, taf ellinnen, beddegoed, kombuisgoed, dranken ( $\pm 2.000 \mathrm{flesch})$ enz. voor 500.000 Rds. papier; Lintelo zal direct betalen zooveel als Weesmeesteren er op willen leenen.

Vincent (Anthony), geb. in Demerary, schijnt eerst na de verovering op Java gekomen; wordt Proc. 25 Juni 1814 Postmaster of Batavia; Proc. 13 Juli 1814 bovendien lid van het Commercial Committee; Proc. 17 Febr. 1815 bovendien nog Translateur bij de Weeskamer; Proc. 14 April 1815 Adjunct Secretaris en Proc. 27 Oct. 1815 Secretaris der Weeskamer op 600 Java Roep. Hij was toen nog maar 26 jaar; pleegde oneerlijkheden en werd in 1817 gearresteerd. Was getrouwd met Sara Wilhelmina van Groll, dochter van Gerard v. G., die lid van de Weeskamer was. Door zijne vrouw was hij geparenteerd aan Dupuy. Hij overleed 21 Mei 1828 insolvent als Secretaris te Padang.

Eene E. C. Vincent trouwt te Bat. 2 Sept. 1848 met den Gouv.Gen. J. J. Rochussen. Zij overlijdt te Buitenzorg 14 Aug. 1851, oud 24 jaar.

Vodegel (J. H.), bij de verovering Eerste Luit. der genie, was in Juni 1813 onder Cornelius werkzaam als drawman and assistant geographical surveyor; wordt in Juli 1815 (met Knops) op 200 Java Roep. ter beschikking gesteld van Captain Baker te Solo.

Vos (Cornelis) (schoonzoon van J. Hesselaar, den Drost van Pasoeroean), vroeger Schout te Koeripan in het Buitenzorgsche, was 
bij de verovering Drost van Soemenap; moest 30 Aug. 1811 zijn huis op last van Captain Harris overgeven aan den Acting Resident Maitland; hij werd gearresteerd en aan boord gebracht en bleef eene maand gevangen; bij zijn terugkeer vond hij zijn meeste goed gestolen. In het voorjaar van 1812 werd hij Deputy Bailliew te Probolinggo op 125 \$. Het oproer aldaar in Mei 1813 kostte hem zijne betrekking. Proc. 28 Oct. 1814 wordt besloten, hem te Bat. te interneeren, omdat hij te Soerabaja praatjes heeft uitgestrooid over de a.s. komst van Comm.-Generaal. In 1815 werd hij uit Pasoeroean (hij had van zijne schoonmoeder de helft van den suikermolen Kadawoeng overgenomen) naar Bat. opgeroepen wegens opnieuw gegeven misnoegen; ditmaal wapende hij zich met een geneeskundig attest, waarop hij gratie kreeg. Na de teruggave trad hij op als provisioneel Resident van Pasoeroean. Wordt in 1819 Resident van Pekalongan (Van der Kemp, N.-I. Bestuur p. 36 noot 3 en Herstel p. 241). Zijne vrouw Maria Cath. Hesselaar overleed te Pasoeroean 23 Aug. 1845; hijzelf aldaar 4 Maart 1847, oud 68 jaar. Een G. Lebret noemt hem , ,behuwdoom”.

Vriese $(G$.) van Oostzaan, op Java gekomen 1 Febr. 1804 als 3e Chirurgijn op 's lands fregat de Pallas, was bij de verovering Secretaris van den Landdrost der Batav. Regentschappen en beambtschrijver te Buitenzorg, daarna Secretaris van den Commissary P. Th. Couperus; wordt 2 April 1812 Opziener 2e klas te Tjiandjoer op 75 \$; den 22 Maart 1814 wordt ook de afdeeling Bandoeng wegens het ontslag van De Wilde onder V. geplaatst; zijn salaris bedroeg toen 220 Java Roep. In Mei 1816 heet hij Assistant Resident. Zijne vrouw was J. C. Chanier. Hij repatrieert in 1826 met zijne vrouw B. J. Martens. Vertrekt opnieuw met zijne familie naar Nederland begin 1837 .

Waal (J. L. de), Lieutenant, wordt Proc. 24 Aug. 1813 benoemd tot Assistant to the Resident at Bantam op 150 \$, ingaande 1 Juni 1.1. Toen Yule den 21 Jan. 1816 op reis ging, droeg hij hem het civiel en militair gezag over; Proc. 11 Maart 1816 werd Ensign Soady tot Assistant benoemd gedurende Yule's afwezigheid op 300 Java R.; begin Juli 1816 kwam Yule eerst terug en nam zijne bezigheden weer op. Onze man teekende: Dewaal; dat men hem zoo spoedig door een Engelschman verving, doet $\mathrm{mij}$ hem voor een Hollander houden; hij was echter officier bij een bataillon, dat anders uitsluitend Engelsche officieren had (Directory 1814). 
Waanders $(H$.$) werd in 1810$ Pastoor te Soerabaja; is dit nog in Aug. 1815. Salaris 75 \$. Overlijdt aldaar als Pastoor in ruste 9 Nov. 1833.

Wardenaar $(W$.$) , biographie in Priangan I, 99$ e.v.; was bij de verovering Raad Extrao. van Indië; wordt in Nov. 1811 tweede persoon bij de commissie tot overname van Palembang; komt vandaar te Bat. terug 6 Dec. 1811. Dringt er in Juni 1812 krachtig op aan, dat de voorgenomen expeditie naar Japan zal geschieden onder de Nederlandsche vlag en ,op naam der Hollanders”. Gaat omstreeks 1 Juli 1813 met die expeditie naar Japan; komt terug 20 Dec. 1813 o.a. met H. Wardenaar (gewezen leerling der Marineschool); volgens Doeff was Abraham Wardenaar meegegaan als Secretaris. Krijgt Proc. 22 April 1814 ter belooning 25.000 \$. Blijkens testament 9 Mei 1814 (Piepers no. 2559) leefde hij met C. M. Hoogendorn, weduwe van E. Rugaud. Volgens Doeff (Herinneringen p. 75) leed hij aan bronchitis.

Bij besluit van den Herv. kerkeraad te Bat. 7 Aug. 1800 wordt toegestaan het verzoek van W. Wardenaar en zijne vrouw, dat hun vóór den echt geboren kind, ,thans door voltrokken huwelijk gewettigd", als zoodanig zal worden ,te boek gesteld" en dat nog 4 andere kinderen, te Samarang ,in gelijk geval gedoopt”, hetzelfde voorrecht zullen genieten.

Wardenaar (J. W. B.), geb. te Samarang 1785 , zoon van den vorige, wordt in 1798 leerling der Marineschool te Samar.; is in 1801 Cadet der genie, 1805 Vaandrig ingenieur; verricht in 1805 en 1806 met anderen opnemingen van tempels bij Prambanan, waarvan teekeningen werden vervaardigd (Priangan I, 101). Den 3 Juli 1805 schrijft Van Naerssen te Grissee aan Nic. Engelhard over de komst aldaar van den bombardier Hedrich met den Cadet Wardenaar in verband met de opneming van oudheden in den Oosthoek; dit was echter niet J. W. B. maar zijn broer Hendrik Jacob, die blijkens het jaarverslag der Marineschool den 17 Mei 1805 met gezegden bombardier op reis ging ,na den Oosthoek ter afteekening van landen zeegezigten etc." en medio December terugkwam.

j. W. B. is bij de verovering Kapitein der genie, na in het begin van 1811 lid te zijn geweest eener commissie tot opname van Djapan en Djipan. Proc. 4 Jan. 1812 is hij op 100 \$ provisional Assistant to the Engineer at Sourabaya. Van 14 Febr. tot 14 April 1812 hielp 
hij Colin Mackenzie (zie aldaar) bij de opname van den Oosthoek. Den 23 Juni 1812 wil Cornelius dezen W. ,dat eene zeer kundige meeter is", gebruiken voor eene opname van den Oosthoek; eene beslissing dienaangaande wordt echter Proc. 15 Aug. 1812 uitgesteld, en bij schrijven van 11 Nov. 1812 gelast, dat hij zich zal stellen ter beschikking van de commissie voor den landverkoop in Soerabaja tot het verrichten van de noodige opmetingen. Proc. 28 Mei 1813 heet hij landsurveyor te Soerab. op $50 \$$. Wordt 11 Jan. 1814 geplaatst onder de orders van Captain Taylor, die belast wordt met de zorg voor de openbare gebouwen aldaar. Proc. 22 Aug. 1815 wordt hem gelast om, wanneer zijne kaart van Probolinggo voltooid is, een plattegrond te vervaardigen van Modjopahit met teekeningen van tempels en poorten op een salaris van 300 Java Roep.; hiervan is de beschrijving bewaard gebleven, zie Priangan u.s.

Wij noteeren, dat aan zijne eerlijkheid in het financieele nog al wat moet hebben gehaperd.

Watcrloo (Matthijs), zoon van een kuipersbaas te Amsterdam, geb. 1769, wordt in 1780 hooplooper; komt in 1785 op de Marineschool te Samar.; wordt 1788 Cadet der Marine en 3e onderwijzer bij die inrichting; gaat 1789 als pennist naar Solo; is 1793 genieofficier te Samarang; wordt 1795 Boekhouder op Banda; verlaat Banda 1797; wordt 1798 Tweede Resident te Djokja; 1803 Eerste dito; 1808 lid der Administratie der Houtbosschen; 1809 Resident van Cheribon, wat hij nog bij de verovering was. Wordt door Raffles bij schrijven van 17 Sept. 1811 als zoodanig gecontinueerd, doch overlijdt 6 Mei 1812; soort necrologie in Gaz. 23 Mei 1812. Het geheim van 's mans plotselinge carrière anno 1798 is mij niet duidelijk geworden.

Zijne weduwe Stoffelina Wilhelmina van Duijn leefde in 1827 te Samarang; hun zoon Willem Jacob W. overlijdt in 1827 als Ass. Res. te Kretek. Diens zuster Sara Francina trouwde met H. J. Domis.

Watson (Thomas C.), Lieutenant Bengal European Regim., wordt Proc. 22 Jan. 1813 benoemd tot Assistant in the Lieut. Gov.'s office op 200 \$; Proc. 9 April 1813 heet hij First Assistant, op hetzelfde traktement. Wordt Gaz. 10 April 1813 Extra Aide-de-camp to the Lieut. Gov. In Dec. 1813 en Jan. 1814 is hij waarnemend Secretaris van Raffles tijdens diens reis over Java. Bij Gen. Orders 3 Febr. 1814 bevorderd tot Aide-de-camp. In Nov. 1814 teekent hij weer 
als Assistant van Raffles. Begeleidt Raffles in 1815 weder op zijne reis over Java, en houdt daarvan een journaal dat gedrukt is in Asiatic Journal, Deel I. Proc. 3 Nov. 1815 wordt hij benoemd tot Superintendent of public buildings and works te Bat. op 880 Java Roep. Fendall bevestigt hem als Aide-de-camp, Gaz. 20 April 1816. De Captain Watson, die in 1820 bij Raffles te Benkoelen was (Widow p. 713), was denkelijk dezelfde; wanneer (ib. p. 512) vermeld wordt, dat in 1821 te Benkoelen overleden all those who had been in my confidence in Java, wordt hij waarschijnlijk meebedoeld.

Wedding (Phil.) van Amsterdam, kwam 20 Juli 1810 op Java als R. K. pastoor; krijgt Proc. 21 Febr. 1812 als Pastoor te Batavia een salaris van 75 \$ p. m.; Proc. 30 Juni 1814 bedraagt dit 330 Java Roep. Den 21 Aug. 1813 plaatst hij eene advertentie in de Gaz. om te danken voor eene inschrijving te zijnen bate wegens een door hem geleden ,,verlies”, waarbij een boedjang, die W.'s ,eigendom” verdedigde, het leven had gelaten. In Nov. 1813 woonde hij ,,in het campement op Weltevreden”; in Jan. 1815 ,,bij de heer Villeneuve”, dus in diens logement. Proc. 13 Maart 1815 werd hij benoemd (dus als opvolger van Van Beusechem) tot Bewaarder der Hollandsche archieven (geborgen op het Gouv. huis op Molenvliet) onder toekenning van een salaris, dat hem tevoren reeds provisioneel was toegelegd; den 10 Juli 1815 schrijft de Regeer. daarover aan het Opperbestuur: „Much information has already been derived from his assiduity and research". Ook is hij Bibliothecaris van het Bat. Genootschap en Secretaris van het Bijbelgenootschap (Bijdr. 1911 p. 344) geweest. Kreeg in 1820 den Ned. Leeuw. Overleden 1825. Zijne begrafenis vermeld in Bat. Cour. 6 Juli 1825.

Bij S. Roorda van Eysinga (Verschillende reizen I, 2 p. 5) wordt aan pastoor Wedding veel lof toegezwaaid wegens zijne bestrijding der slavernij met hulp van het "Menschlievend Genootschap” te Batavia. Diens zoon (aldaar III, 260) noemt hem ,,den braven pastoor Wedding, die door zijne verlichte denkbeelden en buitengewone menschlievendheid geëerd en bemind werd".

$W \operatorname{erff}(H . T$. van der), bij de verovering Eerste Luitenant, wordt 29 Jan. 1812 ter vervanging van Van Lawick door Hope benoemd tot provisioneel Landdrost van Rembang; neemt 1 Febr. die residentie over; de Regeer. keurt zijne aanstelling goed 4 Febr. Hij heet nu eens Drost, dan weer Landdrost of Resident. Proc. 17 Sept. 1813 kriigt hij 50 \$ wachtgeld. Een ware pummel. 
Wilde (A. de), biographie in Priangan I, 284 e.v. Is bij de verovering Opziener der eerste klas te Trogong (Bandoeng); wordt bij besluit van 2 April 1812 als zoodanig bevestigd op 100 \$; heet nu eens Overseer, dan weer Assistant. Den 22 Maart 1814 wordt zijn verzoek om ontslag ingewilligd. In een brief van 12 Mei 1814 vermeldt Res. Macquoid zijn knowledge of the Sunda language and the great confidence which the natives of these Districts have in him in consequence of his long residence among them.

Geeft zich veel moeite voor de invoering der vaccine en wordt Proc. 13 Mei 1815 tot Superintendent of vaccination in de Preanger benoemd op 500 Java Roep.; tot zijn ressort behoorde ook Cheribon. Nog na het Eng. bestuur bleef hij met deze werkzaamheden belast. Over zijn koop van het land Oedjoengbroeng en zijn aandeel in den kcop van Soekaboemi zie de biographie hierboven vermeld.

Willians (Thomas), Lieutenant, kwam met Hopkins, die familie van hem was, van Calcutta en werd Proc. 9 Febr. 1813 benoemd tot Assistant to the Superintendent General of Forests op 200 \$. Als zoodanig vinden we hem dat jaar werkzaam in Rembang; toen echter zijn chef Hopkins was overleden, werd hij bij schrijven van 2 Jan. 1814 belast met de voltooiïng van den aanslag dier residentie, zoodat hij voortaan teekende als Commissioner of Revenue of als Collector; hij had zich ook het Customhouse aangematigd. Eigienaardig is, dat hij ook teekent als J. Williams. Bij schrijven van 1 Sept. 1814 wordt hij aangewezen als Commissioner over de Landrevenue in Grissee, Sidajoe, Lamongan, die worden afgescheiden van Soerabaja; dienzelfden dag geeft hij zijne papieren als Collector te Rembang over aan Resident Davidson, en neemt in die maand zijn nieuw ressort over van Pemberton; reeds 24 Dec. 1814 kan hij melden, dat de aanslag van Grissee en Lamongan is verricht; toen ook zijn werk in Sidajoe was afgeloopen en de Regeer. den 4 Juli 1815 aan Van Naerssen had bericht, dat deze voortaan het Revenue Dept. zijner residentie zou beheeren, werd W. bij schrijven van 17 Juli 1815 benoemd tot Assistant Resident te Samarang op 1.000 Java Roep. p. m. ter vervanging van den in April vertrokken Hardy; niettemin moest hij in Nov. weer naar Grissee om te rapporteeren over den staat der inning van de landrente aldaar. Proc. 1 Jan. 1816 werd Captain D. Macleod tot zijn opvolger benoemd, terwijl hij zelf zich weer bij den troep zou voegen; deze aanvaardde zijne betrekking 11 Jan. 1816. Uit Crawfurd, History II, 199 blijkt, dat W. dezen verslag gaf van zekere tempelruinen aan den berg Lawoe. 
Wilson (J. G.) wordt begin Nov. 1811 benoemd tot Deputy Accountant (ook genoemd English Assistant van den Accountant) en Proc. 28 Nov. 1811 tot Superintendent of the printing office. Overlijdt 9 Mei 1812.

Wiltenaer $(H, E$.$) , geboren op Ternate 1768$ als zoon van den predikant E. J. Wiltenaer, die van Zutphen was. Kwam op Java 1774. Werd de man van H. C. Thierens van Malakka, wier vader aldaar Secunde was geweest. Was bij de verovering Oud-schepen titulair en (reeds sedert 1794) Kassier van het Vendukantoor, tevens Boekhouder daarvan; sedert 23 Nov. 1811 was zijn salaris $200 \$$ p.m. Overleed als zoodanig 9 Jan. 1816; liet behalve het land Pondoktjina een ruim woonhuis na aan de zuidzij van den weg van Jacatra benevens een belangrijk tekort in de kas van het Vendukantoor.

Winckclmann (Carl von), geb. te Regensburg in Beieren 1772, ging naar Indië 1793 als onderofficier, werd in 1804 van Kapitein koffieopziener; was bij de verovering Inspecteur-Generaal der koffiecultuur; vroeg als zoodanig 16 Oct. 1811 ontslag om naar Europa te gaan; den 10 Nov. schrijft Hope echter, dat hij zuinigheidshalve ontslagen is. Den 1 Aug. 1812 vraagt hij dan ook vergunning om naar Europa te vertrekken, teneinde zijne familie te hulp te komen; dit wordt toegestaan, maar aangezien den 13 Oct. 1813 de acte werd geteekend, waarbij hij een stuk grond te Pekalongan huurde om er een huis te bouwen, is het waarschijnlijk dat hij niet gegaan is. Den 12 Maart 1814 verzoekt dit wispelturige hqerschap wegens ziekte verlof om naar de Kaap te gaan en om zijn grond in Pekal. te mogen overdoen aan De Beauregard; ook dit wordt 21 Maart toegestaan, maar of hij toen vertrok, blijft weer de vraag. Proc. 1 Dec. 1815 wordt hij op 400 Java Roep. p. m. met vrij reiskosten benoemd tot Deputy Inspector of coffee culture voor de strandresidenties van Cheribon tot Japara. Hij was dit nog bij de teruggave. Hij ging naar Europa einde 1822. Overleed te Tjiandjoer 25 Aug. 1841 als gepensionneerd Inspecteur der koffiecultuur en Ridder van den Nederl. Leeuw.

Winckelmann ( $F$. von, voluit F. C. P., ook genoemd Kolonel von W.), geboren te Meiningen in Saksen; kwam aan de Kaap 1787; op Java met het regiment Wurttemberg 1805; was bij de verovering 
Brigadier en commandant te Samarang. Den 26 April 1812 verzocht Hope, dat deze oud-officier, mits presteerende den eed van trouw, op het eiland zou mogen blijven, hetgeen in Mei werd toegestaan. Wanneer wij hem dus reeds Proc. 4 Jan. 1812 ontmoleten als Deputy Superintendent der Houtbosschen op 250 \$, moeten wij wel aannemen, dat hij een half jaar lang zonder eed van trouw diende. Zijne tijdelijke benoeming tot Inspector of Forests bevat eerst de Gaz. van 4 April 1812; de formeele benoeming tot Deputy Superintendent and Fiscal op $400 \$$ volgde kerst bij Proc. 9 Febr. 1813; maar wederom bespeuren wij reeds Proc. 10 Oct. 1812, dat zijn salaris evengemelde som bedraagt. Den 5 Nov. 1812 werd hij lid der commissie voor den landverkoop in Samarang. Blijkbaar had men hem erg noodig, en wel speciaal als tolk van den Superintendent Hopkins; deze schrijft eerst 21 Aug. 1813, dat hij het wel zonder zijne hulp kan stellen. Na Hopkins' overlijden volgde bij Proc. 3 Febr. 1814 von W.'s benoeming tot waarnemend Superintendent, hetgeen hij gebleven is tot de benoeming als zoodanig van Campbell Brown in Nov. 1814, toen hij weer terugtrad tot Deputy. Zijn salaris als zoodanig was in 1815 per maand 800 Java Roep. Hij woonde te Samarang en had twee zoons en drie dochters, waarvan eene trouwde met P. I. van Teylingen. Hij overleed te Samarang 29 Juli 1820, oud 63 jaar. De weduwe heette A. H. C. Samlant.

Young (William), geboren te Dacca in Bengalen 1787, komt Proc. 10 Oct. 1812 voor als Deputy Fiscal van het Court of Justice op 200 \$ (benoeming bij schrijven van 14 Nov. 1812) benevens President and First Commissioner van het Court of Requests op 300 \$ (benoeming bij schrijven van 7 Nov. als bekend zijnde met de customs and practices of British Courts; Cranssen bleef Superintendent van het Court of Requests maar voerde niets uit); bij publicatie van $28 \mathrm{Mei}$ 1813 benoemd tot First Commissioner van het Court of Requests op 200 \$ en nog bovendien lid en Secretaris van het Revenue Committee op 100 \$. Den 1 Nov. 1813 wordt hij, als gaande met verlof, vervangen als Adjunct Fiscaal van het Supreme Court, Secretaris van het Rev. Comm., en First Commissioner van het Court of Requests. Hij vertrekt naar Penang 17 Dec. 1813 en komt 11 Maart 1814 te Bat. terug; wij vinden hem 30 Juni 1814 weder als Adjunct Fiscaal en Gouvernements Notaris op 800 Java Roep. en in 1815 bovendien als lid van het Revenue Comm. en als Vice-Pres. der Weeskamer. Met 1 Sept. 1815 werd hij lid der firma Jessen, Trail 
en Co., hetgeen hij 1825 nog was; hij trouwde 7 Sept. 1815, zijnde Vice-President der Weeskamer en Advocaat Fiscaal English Department, te Bat. met Charlotte Geertruida de Haart van Colombo, jongedochter. Daarop trad hij af als Vice Pres. der Weeskamer. Hertrouwde 25 Febr. 1827 te Bat. met J. J. H. de Lannoy van Colombo. Woonde nog in 1828 te Bat. Overleed aldaar 28 Aug. 1841 , oud 52 jaar.

Ysseldijk (Wouter Hendrik van), zoon van Ds. Joh. van Ysseldijk te Utrecht en Cath. Geertr. van Senden, geb. te Utrecht 31 Dec. 1755, vertrok in Nov. 1776 uit Texel, was bij de verovering lid der H. Regeering en Oud-Directeur-Generaal; ruineerde zich in 1811 door verschillende verliezen; ,hij bevond zich in denzelfden staat als toen hij in 1776 Texel verliet" (Dr. de Roo II, 534). Wordt Proc. 12 Maart 1813 Directeur der Lombard Bank op 400 \$; Proc. 28 Mei 1813 heet dit salaris 500 \$. Wordt Proc. 22 Dec. 1814 waarnemend President der Weeskamer op 750 Java Roep., welk salaris Proc. 6 Jan. 1815 wordt verhoogd tot 1.000 en Proc. 27 Oct. 1815 tot 1.100 Java Roep. Krijgt Proc. 13 Maart 1815 een compliment wegens zijn goed beheer der Lombard Bank, hoewel de Regeering Proc. 3 Febr. 1814 aan het bestuur dier Bank haar misnoegen had betuigd over het verzwijgen van zekere knoeierij. Zijn beheer der Weeskamer was minder prijzenswaard. Was door zijne verkwistende levenswijze een der toonaangevende figuren van Bat. Op Koningsverjaardag 4 Juni 1813 officieel feest, waarop officieele toast op Mrs. van Ysseldijk (van Padang, van zich zelve Johanna Maria Magdalena Oland, dochter van Pieter Oland, essayeur en weesmeester te $\mathrm{Pa}-$ dang) and the Ladies of Batavia; feest ter eere van zijn trouwdag zie Gaz. 2 Sept. 1815: Raffles en andere dignitarissen zijn present. Hij was in 1815 eigenaar van het land Tjilodong. Den 4 Aug. 1816 vertrekt hij van Bat. over zee naar Grissee, vermoedelijk in verband met zijne zending door Comm.-Gener. naar de Vorstenhoven. Overleed als Resident van Solo 12 Mei 1817, oud 61 jaar. Knappe kop, slap karakter. Door Daendels zeer terecht gekwalificeerd als ,den zwaksten man en den slegsten financier van Java". Van zijne zoons zijn verscheidene insolvent overleden. Maar zijne dochter Joh. Henriette Catharina hertrouwde in 1823 met Prof. C. G. C. Reinwardt. De weduwe Ysseldijk-Oland overleed eerst in 1839.

Yule (Udney) (de zonderlinge voornaam van dezen heer is de familienaam van een geslacht, een der leden van hetwelk in 1805 
Vice-President van den Council te Calcutta was), Major, daarna Lieutenant-Colonel der Bengal Native Inf., nam deel aan de bestorming van Meester Cornelis (Widow p. 93 ; 94; Conquest p. 60); neemt in het laatst van Sept. 1811 Rembang over; komt 18 Oct. 1811 te Soemenap als Major, commanding Madura, waar hij het civiel gezag overneemt (Maitland was reeds vertrokken) en vervolgens een Drost daarmee belast. Proc. 1 Nov. 1811 wordt, in verband met zijne benoeming door Minto tot Resident van Bantam en commandant te Anjer, zijne overkomst naar Bat. gelast; doch eerst in Dec. wherd hem in Clark een opvolger op Madoera gegeven en pas 26 Jan. 1812 vertrok hij van Bat. naar Bantam, waar hij vervolgens tot de teruggave is gebleven als Resident op het hooge salaris van 750 \$, later 1.200 Java Roep., ongerekend zijn traktement als officier, want hij bleef tegelijk militair commandant. In Jan. 1816 werd hij bendemd in de commissie van onderzoek naar aanleiding der Sepoy samenzwering; den 21 Jan. draagt hij het civiel en militair gezag over aan Luitenant De Waal; laat 23 Maart een paard meerennen bij de races te Djokja; komt 20 Mei van Samar. te Bat. terug, doch neemt eerst in het begin van Juli het gezag in Bantam weer over. Eind Nov. 1816 was hij nog op Java. Waarom Van Deventer p. LXXXIX hem een bekwaam man 霣oemt, is mij niet bekend, wel dat hij de leelijkste hand schreef van heel Java; echter noemt ook Minto hem an excellent and intelligent officer. Proc. 27 Oct. 1815 bericht hij, dat in minder dan een jaar 300 kojan, zegge ruim een millioen pond, zout spoorloos verdwenen is uit het Bantamsche pakhuis, en verzoekt dan in één adem om percenten van de zoutbaten, ter belooning van de vele moeite, die het beheer van het zout hem geeft ! President en Raden van Financiën schrijven in een rapport van $11 \mathrm{Juli} 1817$, dat tijdens het Eng. bestuur de Resident van Bantam een monopolie dreef in peper, hoewel de cultuur daarvan vrij was. Francis, die als schipbreukeling door hem als door ,,een vader" werd verzorgd en voortgeholpen, spreekt van hem als ,dien edelen man" (Herinneringen I, $103 ; 104)$.

Zhaetzcky (Joh. Fred.), geb. te Stettin 1769, uitgevaren als jongmatroos 1789, was bij de verovering Opperhoofd van het Generale Tractementskantoor, President van Commissarissen van Huwel. en Kleine zaken en Curator ad lites. Wordt bij Besl. van 23 Nov. 1811 benoemd tot Drost (eene benaming, door Daendels ingevoerd inplaats van dien van Onderprefect) van Tegal op 200 \$; hij heet echter ook 
wel Landdrost of Resident, zelfs toen Tegal nog onder Cheribon ressorteerde. Den 23 Mei 1813 gaf hij Tegal over aan Keasberry, na Proc., 24 April 1813 te zijn benoemd tot President der Weeskamer te Samarang op 250 \$. Overleed als zoodanig 14 Dec. 1817. Een misselijk type.

Zimmer (J. B.) van Kannstadt in Wurttemberg, was in 1798 , toen hij trouwde met S. H. Roode van Bat. (dochter van J. H. Roode, die jaren lang Opziener in het Buitenzorgsche was geweest), korporaal; later bracht hij het tot sergeant en was tegelijk ,,vleeshouwer”, namelijk leverancier of baksmeester van het garnizoen, wat veel reizen noodig maakte voor den opkoop van beesten. Een ondernemend man. Koopt in 1808 de Hollandsche Kerk voor afbraak. In 1812 had hij eene toko aan de Kalibesar en tevens een logement met wagenverhuurderij in de buurt van het kampement Weltevreden; reeds in 1809 was hij aannemer der posterij tusschen Bat. en Buitenz.; zijn contract daarvoor met de Regeer. deed hij in 1812 over aan A. W. L. van Gesseler te Lintelo (zie boven, Villeneuve). Bij den Krawangschen landverkoop trad hij op den voorgrond, doch overleed reeds 14 Juli 1813; over den verkoop van zijn boedel zie Gaz. 29 Jan. 1814. Uit zijn testament (Piepers 20 April 1812 no. 696) blijkt, dat hij zeer vermogend was.

Zwekkert (J. A.) van Colombo of Jafnapatnam, was aldaar Onderchirurgijn; wordt bij Resol. van 6 Nov. 1798 weder in dienst te Bat. aangenomen als Chirurgijn; werd den 14 Nov. 1800 van Onderchirurgijn benoemd tot Essayeur en Muntmeester, destijds te Bat., later te Soerabaja (in de Bijlagen bij de Resol. van dien datum vindt men een rapport over het hem afgenomen examen in beide qualiteiten), en was bij de verovering ook lid van den Raad van Justitie te Soerabaja. Bleef er onder het Eng. bestuur muntmeester en essayeur op 100 \$ en ook daarna tot 1819 . Zijne weduwe J. S. Fretz hertrouwde in 1820 . 


\section{REGISTER}

OP PERSOONS-, PLAATS- EN SCHEEPSNAMEN.

Abdullah 529, 653.

Abercromby 560 .

Abraham 483, 505.

Adams 483-485, 508, 522, 533, 534, $538,541,574,575,577,581,589,625$, 634.

Addison (G. A.) 485-487, 489, 491, $496,504,522,540,579,606,610,622$, 629, 646.

Addison (R.) 487.

Adikoesoema 637.

Adimonggolo 485, 535, 592, 636-641.

Admiral Drury 494.

Affelen van Saemsfoort (v.) 487.

Ainslie (D.) 487-490, 501, 528, 533, $564,635,650$.

Ainslie (J.) 487, 489.

Ainslie (W.) 487, 489, 523, 528, 537, 561, 626, 648.

Ali Pascha 551.

Alkmaar 536.

Alphen 487.

Alting 525.

Ambarawa 577.

Ambon 490, 499, 525, 526, 590, 605, 633.

Amerika 494, 518, 550, 610, 611.

Amerongen 557.

Amersfoort 502 .

Amsterdam 506, 507, 517, 524, 608, 614, $620,623,646,662,663$.

Angkee 642 .

Anjer 508, 514, 558, 571, 580, 599, 668.

Arblay (d') 513 .

Arinus Marinus 621.

Arnold 509.

Arrakan 633.

Assey 486, 488-491, 494, 510, 533, 540, $550,574,577,648$.

Atjeh 562 .

Auchmuty 491, 597, 630.

Bach 491.

Bagdad 551.

Bagoes Rangin 487, 506.
Bakel 633.

Baker 491, 492, 592, 659.

Bali 484, 488, 527, 533, 560, 562, 566, $567,574,591,601,605,612,622,628$, 649.

Banda 564, 580, 662.

Bandarjejer 586.

Bandjarmasin 483, 500, 562-566, 610, 633.

Bandoeng 509, 510, 651, 660, 664.

Bangil 484, 581.

Bangkalan 489, 516, 527, 533, 534, 593, 628.

Banjoekoening 577.

Banjoemas 645 .

Banjoewangi 488, 516, 532, 533, 544, $549,570,577,581,586,588,591,598$, $599,601,605,632,635$.

Banka 505, 541, 544, 559, 564, 583, 587, 609, 617, 627, 630, 633.

Banks 583 .

Bannisseht (v.) 492, 493.

Bantam 487, 512, 535, 539, 544, 568, $606,609,622,660,668$.

Barbier 566.

Barkey 507.

Barrett 493, 646.

Bartels 602.

Batavia, passim.

Bataviasche Regentschappen 524, 606, 651, 654, 660 .

Batenburg 630.

Bath 590.

Baud 493-495, 506, 507, 560, 598, 615, 645.

Bauer 486, 489, 490, 495, 496, 500, 505, $510,540,636$.

Bawean 593, 620, 642.

Beauregard 497, 617, 665.

Bee 621 .

Beeckman 613.

Beetjes 497, 498.

Beieren 665.

Beillard 651. 
Beke (v. d.) 626.

Benares 514.

Bengalen 486, 488-490, 493, 496, 500, $502,508-510,517,523,526,540,543$, $549.554,555,558,569,570,578,580$, $581,599,602,609,614,617,621,625$, $628,632,639,643,666$.

Benkoelen 583, 610, 621, 630, 646, 654, 662.

Bentinck 599.

Berg 521.

Bergsma 502.

Berlijn 649.

Bethlehem 582.

Betsy 633 .

Beumert 591.

Beusechem (v.) 498, 504, 663.

Beylon 614.

Bezoeki 488, 490, 522, 527, 531, 533, 548, 549, 570, 577, 581, 593, 606, 635 .

Bidara Tjina 538, 644.

Bidwell 493, 499, 505, 513, 528.

Bima 488, 632.

Bingley 499.

Birkhoven 502.

Blagrave 490, 499, 500, 531, 555, 556.

Bloem 500, 501, 565.

Blomhoff (Cock) 501, 502.

Blommestein 502, 503.

Blora 566.

Blume 526.

Bodjong 487, 505, 576, 578, 638, 650 .

Boeckholtz 498, 503, 504, 600, 613.

Boehm 508, 509.

Boeleleng 488, 533, 562, 640.

Boenga 656.

Boggie 483, 498, 504-506, 532, 568, 598, 638, 640 .

Bois 506 .

Bolton 506.

Bombay 531, 544, 622, 647.

Bonaparte 571.

Boni 506, 527, 560, 605, 628.

Boompjes-eilanden 600 .

Borneo 548, 565, 597.

Boroboedoer 520, 522, 584.

Borwater 507.

Bosch 619, 622.

Boswel 507, 512.

Bourtange 512 .

Bousquet 636 .

Bowerno 532, 651.

Braam (v.) 484, 495, 507-509, 568, 616.
Braband 623, 633.

Brandel 509, 539.

Brandenburgh 509, 510.

Brata Joeda 504, 637, 640.

Breda 560, 570, 614, 617, 641.

Bremer 538.

Breton van Groll 628.

Broeck (v. d.) 510.

Broenei 585.

Brooke 514.

Broughton 649.

Brouwer 509.

Brown (Campbel1) 510, 511, 546, 597, 647, 666.

Browne 511, 537.

Broxbournbury 485.

Brückner 511, 512, 614.

Brummen 536.

Brunswijk 526.

Bruijn (J. de) 512.

Bruijn (A. E. de) 557, 558.

Buitenzorg 486, 487, 490, 494, 499, 504, $509,510,520,524,531,538,539,544$, $553,559,561,567,568,570,571,578$, $579,588,590,594,595,601,602,605-$ $611,613,620,626,628,637,638,645-$ $647,651,658-660,669$.

Burger 508, 512, 616, 624.

Burghgraaf (J. W.) 512 .

Burghgraaf (W. J.) 526.

Burke 601, 603.

Burney 498, 512, 513, 523, 527, 594, $625,627$.

Burslem 513, 514.

Bus (du) 521.

Busch (v. d.) 538.

Busscher 514.

Buys 496.

Buyskes 616 .

Calcutta 485, 490, 496, 505, 508, 517, $534,540,544,552,556,560,568,569$, $571,583,584,587,599,603,621,629$, $634,639,641,646,652,654,664,668$.

Calderas 657.

Campbell 603.

Canton 580, 585, 633.

Capellen (v. d.) 508, 616.

Carnatic 599.

Cassa 514, 515 .

Catalonië 657.

Cattenburch 566 .

Ceilon 542, 618, 650. 
Celebes 544, 548, 563.

Chanier 660.

Cheribon 487, 497, 506, 513, 514, 527, 532, 534-536, 543, 544, 560, 570, 572, $576,578,587,593,594,597,602,604$, $606,607,611,627,628,630,636,645$, $646,655,662,664,665,669$.

China 507, 580, 585, 614, 633.

Chinnery 551 .

Chinsura 621, 644.

Chittagong 628.

Christiani 515.

Christophorus Columbus 517.

Clark 516, 538, 591, 599, 605, 668.

Cluver 516, 633, 649.

Cochin 548, 599.

Colebrooke 516, 517, 543, 555, 609.

Colombo 650, 667, 669.

Colvin 499.

Comans 557.

Connecticut 584 .

Conroy 517, 560.

Coolen 583.

Cork 551.

Cormandel 491, 586, 617.

Cornelius 514, 517-522, 538, 544, 549, $550,590,592,603-605,659,662$.

Cornwallis 621 .

Cotes 485, 486, 489, 513, 522, 523, 527, $541,542,548,581,618$.

Couperus (A.) 523, 524, 645, 652.

Couperus (C. E.) 525, 645 ; (G.) 652.

Couperus (P. Th.) 524-526, 531, 606, 660.

Court 631

Cranssen 483, 488, 501, 503, 506, 512, $524-526,600,615,616,645,646,666$.

Crawfurd 484, 488, 489, 498, 513, 522, $526-530,532,534,535,541-543,549$, $561,564,566,570,571,577,581,584$, $585,588,596,623,630,633,637,640$, 664.

Dacca 666.

Daendels 487, 495, 507-509, 511, 518, $524,525,542,547,557,562,567,568$, $572,573,608,610-615,617-620,623$, $625,633,637,641,650,654,655,658$, 667, 668.

Dalem 644.

Dalgairns 530, 629.

Dalton 530.

Darwin 633.
Dassar 603.

Dat 644

Davidson (J.) 524, 531, 533, 567, 631, 664.

Davidson (John) 531, 607, 647.

Davies 532, 534, 560, 571, 598, 651.

Davis 488, 531-533, 570, 605, 635 .

Davy 484, 490, 513, 516, 532-534, 560, $622,628$.

Deans 530, 534, 535, 547, 571, 643, 644.

Deccan 599.

Decima 501, 502.

Decker 535 .

Delhi 646.

Delft 502 .

Demak 541, 592, 637, 638.

Demerary 659 .

Depok 524.

Deschamps 517.

Deventer 537.

Dewaal, zie Waal (de).

Diëng 492, 520 .

Dillon 506, 535.

Dircks 633.

Discovery 633.

Dixon 536.

Djapan 567, 589, 624, 650, 661 .

Djengot 654 .

Djipan 528, 532, 542, 624, 625, 650, 651, 656, 661.

Djokja 488, 491, 492, 516, 522, 527529, 531, 534, 541, 543, 549, 553-555. $559,561,571,573,574,576,586,588$, $592,600,602,615,628,630,646,648$, $650,651,653,658,662,668$.

Doeff 488, 489, 501, 515, 661.

Domis (E. J. W.) 525 .

Domis (H. J.) 536, 593, 662.

Doornik 511, 536, 537, 539, 559, 561, 618.

Doorninck (v.) 489, 537, 538, 610.

Doppert 583.

Dragheim 516, 538, 548.

Drake 566.

Dramaga 525.

Dresden 509.

Drognat 538.

Drost 502, 509, 538, 602, 616, 624.

Drury (adm.) 547.

Drury (J.) 509.

Dubois 509, 538, 539, 544.

Dudde 557.

Dupuy (J.) 486, 502, 510, 539, 540, 560. 
Dupuy (M. W.) 539, 568, 569.

Duijn (v.) 662.

Eales 485, 513, 527, 537, 540-542, 548, $559,561,578,583,591,606,615,625$, 631.

Eckford 523, 541, 542, 558, 567, 577, $598,625,651$.

Edinburgh 526.

Eekhout 648.

Eisch 536.

Ekeboom 542, 543, 570, 587.

Elliot 555, 596.

Ellis 636 .

Elout 540, 568, 616.

Engeland 485, 493, 501, 502, 508, 527, $540,543,557,597,607,610,614,627$, $629,643,649,654$.

Engelhard (G. F.) 645.

Engelhard (N.) 495, 499, 501, 509, 517, $518,522,525,536,555,568,569,572$, $613,615,617,620,645,661$.

Engelhard (P.) 543, 615.

Entrecasteaux (d') 517, 658.

Erentreich 543.

Ermatinger 543 .

Ernstein 507.

Esch 536.

Everest 543.

Evertse 544.

Farquhar 533.

Farquharson 544, 597.

Faulkner 602.

Feith 507.

Fendall 483, 505, 506, 523, 530, 544, $546,568,595,620,636,638,654,662$.

Fichat 493.

Flikkenschild 519, 539, 544.

Flint 487, 510, 531, 532, 544-547, 574, 606, 608, 631, 636, 643, 648, 653.

Foote 546, 547.

Forbes 647.

Forssteen 547, 587.

Francis 547, 548, 599, 668.

Fraser 607, 648.

Fretz 669.

Gale 626 .

Galoeh 492, 651.

Ganges 549.

Garnham 519, 521, 522, 527, 538, 541,
$548,549,561,564,590,593,620,635$, 650.

Gaspar 633.

Gaudin 502 .

Geldermalsen 593.

Gesseler te Lintelo (v.) 526, 585, 658, 659, 669.

Geugten (v. d.) 521, 549, 550.

Gewiss 658.

Geyrold 562.

Gibbs 484, 490, 511, 533, 548, 550, 551, $556,557,567,573,574,591,598,657$.

Gillespie 490, 491, 500, 505, 540, 551$556,558,559,564,578,580,586,609$, $615,620-622,632,643,651,653,657$.

Gintoengan 577.

Giri 619.

Glansbeek 556.

Godefroy 634.

Goemoelak 591.

Goenoengparang 497.

Goenoengsari 602, 629, 658.

Göppingen 649.

Goes 625 .

Goldbach 507, 533, 550, 557, 558, 612, 636, 637.

Goldman 493, 646.

Grant 492.

Grant Keir 514, 558.

Grasveld (v.) 568 .

Grave (de) 512 .

Gravenhage ('s) 493, 514, 525, 526, 538, 613,653 .

Greene 542, 558.

Grieve 558.

Grissee 484, 523, 543, 558, 564, 567, 588, $601,617-620,622,623,625,643$, $655-657,661,664,667$.

Grobogan 528, 542, 586, 650.

Groeneveld 612.

Grogol 654.

Groll (v.) 539, 540, 628, 659.

Groningen 525, 614, 642.

Grootegast 570.

Gutzlaff (v.) 538, 625, 626.

Haak (A. J. v.) 626.

Haak (Pinket v.) 537, 558, 559, 588.

Haarlem 535.

Haart (de) 667.

Ham 514.

Hanson 517, 532, 540, 559, 560, 583, 645.

Han Tjan Pit 490. 
Harderwijk 620.

Hardy 528， 541， 548，560-562， 567, 593, 595, 598, 607, 610, 641, 664 .

Hare 500, 510, 562-565, 632, 633.

Harris (C.) 534.

Harris (G.) 566, 605, 657, 660.

Harris (R.) 566.

Hart 566, 567, 589.

Hartilieff 489, 531, 567, 594, 618, 622.

Hartman 524, 526.

Hartsinck 524, 567, 568, 610.

Harvey 568.

Havezaate 525 .

Hecate 559.

Hedrich 661.

Heemstede (Cappelhoff v.) 543.

Heerdt (v.) 539, 568, 569, 609.

Heidenreich 506.

Heim (v. d.) 650.

Helena (St.) 652.

Helmig 642.

Helpen 642.

Hertogenbosch (s') 524, 536, 623.

Hesselaar 569, 659.

Heusden 556, 591, 627.

Heyland 511, 522, 537, 569, 570, 595, 597, 617.

Higgins 543, 570.

Hinsch 640 .

Hodges 535 .

Hoegli 507.

Hoff 523.

Holle 654.

Holst de Weerth 533, 570, 635.

Holstein 515 .

Homer 527, 532, 570, 571, 587.

Hood 549, 571, 642, 652.

Hoogendorn 661.

Hoogh (de) 612.

Hoop (v. d.) 571.

Hooreman 615.

Hope 484, 489, 490, 504, 521, 536, 542, $550, \quad 557-560, \quad 571-581, \quad 598, \quad 599$, $601,606,611,616,620,643,655,656$, $663,665,666$.

Hopkins 522, 532, 580-582, 589, 634, $635,655,656,664,666$.

Hornoff 593.

Horsfield 517, 582-584, 619, 630.

Houten (v.) 538 .

Houtman 535.

Hubbard 584.

Huisduinen 557.
Hulft van Hoorn 587.

Hunt 564, 584-586, 617.

Hunter (G.) 569, 586.

Hunter (W.) 488, 587, 597.

Hussar 555, 597, 598.

Ierland 551, 605, 636 .

Indramajoe 487, 497, 607, 608, 616, 623.

Isabella 643, 653.

Isle de France 502.

Ivatts $571,587$.

Jacatra 525, 602, 665 .

Jacobson 587, 588.

Jafnapatnam 651, 669 .

Janke 539.

Jansen 588 .

Janssens 487, 494, 507, 508, 537, 572, $613,617,630$.

Japan 488, 489, 501, 502, 515, 661.

Japan (op Java) 510, 642.

Japara 511, 537, 541, 559, 569, 591, 595, $606,637,638$.

Java's N.O.-kust 504, 518, 572.

Jeboos 587.

Jelleke 591.

Jessen 666.

Joana 536, 537, 541, 547.

Johnson (J. M.) 588, 589.

Johnson (S.) 512.

Jongkind 497, 509, 589, 605.

Jourdan 570, 581, 589, 590, 624 .

Jutting 495, 507.

Kaap de Goede Hoop 591, 608, 623, $630,646,649,653,665$.

Kadawoeng 660 .

Kaisen 644.

Kalunga 556.

Kam 590.

Kampen 525, 642.

Kampong Bandan 629.

Kampongbaroe 645.

Kampongdoeri 642.

Kampong Makassar 489, 561.

Kampong Malajoe 652.

Kamschatka 494.

Kandanghaoer 616 .

Kannstadt 669.

Karangsamboeng 607, 608.

Karimon Djawa 519.

Karsseboom 519, 544, 590.

Kaysen 644. 
Keasberry 532, 590, 669.

Kediri 583, 651.

Kedoe 514, 519, 527, 534, 562, 569, 595, $597,617,641$.

Kedoengbadak 559.

Kemajoran 659.

Kendal 541, 598, 637.

Kenteng 577.

Kentengan 577.

Kentucky 495.

Kerst (v.) 525, 645.

Keyzer 536.

Kew 583.

Kidderpore 639.

Kilian 591.

Kirwan 608.

Klaten 491, 530.

Kletjo 577.

Knibbe 570.

Knight 516, 591, 598.

Knops (Jr.) 492, 591, 592, 659.

Knops (Sr.) 591, 600, 601.

Koedoes 541 .

Koek 524.

Koepang 614.

Koeripan 659.

Koetei 565 .

Koevorden 645.

Kokos-eilanden 565, 632.

Kool 592.

Kopeng 576.

Kopenhagen 652 .

Kortzius 518.

Kram 538.

Kramat Tjilodong 524.

Krawang 494, 497, 510, 594, 606-608, 611, 621, 623, 625, 626, 654, 669.

Kretek 662.

Krokot 525.

Krijgsman 592, 593, 640.

Kuhnau 593.

Laanhof 616, 624, 642.

Lady Bentinck 564 .

Lamongan 484, 664.

Lampongs 539, 609.

Langewagen 593, 595 .

Lannoy (de) 667.

Lanoy (de) 557.

Lasem 536, 641.

Lausanne 623.

Lawick van Pabst (v.) 567, 591, 593, 594, 600, 625, 663.
Lawoe 588, 664.

Lawrence 519, 523, 527, 534, 538, 548, 561, 574, 593-595, 607, 618, 627.

Lebret 569, 660.

Leda 642.

Leeuwarden 523.

Leiden 507.

Leyden 595-597.

Liebeherr (v.) 514, 648.

Ligtman 521 .

Lille 658.

Limbangan 599, 642, 651.

Lippe 498, 503, 600.

Lloyd 569, 597.

Loftie 510, 597.

Lombok 566.

Londen 508, 539, 653.

Loth 620 .

Loudon 532, 542, 577, 591, 597-599, 643.

Louis Philippe 621.

Lubeck 636.

Luik 621.

Luneburg 593.

Lunel 599.

Luyken 522.

Macao 494.

Macartney 599.

Macaulay 513.

Macdonald 534.

Macgregor 599.

Mackenzie (C.) 503, 519, 594, 599-604, 634, 662.

Mackenzie (J.) 516, 599.

Mackenzie (K.) 589, 604, 605.

Maclaine Watson 535.

Macleod (A.) 605.

Macleod (D.) 499, 516, 594, 605, 664.

Macquoid 498, 531, 537, 541, 561, 568, $578,594,595,599,605-608,625,626$, 664.

Madoera 516, 534, 548, 566, 571, 604, 605, 657, 668 .

Madras 487, 523, 552, 568, 571, 590, 600, 601, 647.

Maffé 614.

Maitland 566, 608, 660, 668.

Majapahit 602, 662.

Majoran 658, 659.

Makassar 514, 526, 527, 530, 559, 564 $566,622$.

Malacca 548. 
Malakka 499, 516, 523-525, 544, 562, $605,619,633,649,652,653,665$.

Malang 484.

Malcolm 602.

Manila 585, 657.

Maria Reigersberg 641.

Maroejoeng 525.

Martens 660.

Martheze 608, 626.

Mary Ann 562.

Maughan 644.

Maurik 557.

Mauritius 550, 571, 583.

Meares 609, 631, 659.

Mecklenburg 602.

Meester Cornelis 484, 494, 516, 517, 522, $526,530,531,535,550-552,559,566$, $586,588,589,591,596,620,621,627$, $630,631,642,651,658,668$.

Meeverden (v.) 619, 623.

Meiningen 665 .

Mekka 637.

Menado 608.

Menteng 644.

Merakbaai 517.

Merapi 577.

Merbaboe 577.

Merkus 526.

Methven 504, 517, 537, 555, 561, 607, $609,610,626$.

Meyer (H. E. en J. H.) 652.

Meyer (J. C. L.) 567, 610.

Meyer (L. W.) 503, 610-613, 653.

Meylan 628, 657.

Michiels 535 .

Middelburg 538, 589, 625.

Middelkoop 572, 613, 614.

Mill 621.

Milne 614.

Minden 571.

Minto 484, 486, 491, 508, 517, 524, 526, $543,544,550,552,556,562,565,571$, $572,580-582,587,595,596,598,599$, $601,603,615,616,619,620,622,630$, $632,639,646,649,653,668$.

Minto (= Muntok) 609, 631, 657.

Modeste 630.

Modjopahit, zie Majapahit.

Moesbergen (v.) 619, 620.

Moira 496, 513, 544, 556.

Molenvliet 496, 503, 630, 648, 663.

Moloeka 562, 565, 633.

Molukken 500, 570, 580, 613.
Mom 557, 646.

Montanus 511, 614, 627.

Montrose 489.

Morris 534, 535, 565.

Mulder 626.

Muntinghe 503, 525, 579, 580, 600, 612, $614-617,628$.

Muntok 562, 587, 630. Zie ook Minto.

Murray 569, 586, 617.

Muyderman 518.

Mijer 495.

Mysore 599.

Naerssen (v.) 523, 591, 616-620, 622, $623,634,661,664$.

Nahuijs 556, 609, 610, 613, 620, 621, 644.

Nearchus 622.

Neede 627.

Neitzell 538.

Nelissen 621.

Nepal 556.

Nesnarc 526.

Neun 509.

Newman 603.

New Orleans 550 .

New York 610.

Nicolaas 612.

Nieuwkerken (v.) 622 .

Nightingall 486, 513, 527, 560, 580, 621 . $622,628,657$.

Nisus 630 .

Noesakambangan 492, 524, 556.

Noordwijk 515, 525, 526.

Noressa 636.

Norris Brooke 514.

Norwich 584.

Notodiningrat 639, 641.

Noto Koesoemo 586.

Nugent 554.

Nijvenheim (v.) 567, 618, 619, 622, 623.

Oedjoengbroeng 664.

Oedjoengkrawang 510.

Oelrichs 540.

Oengaran, Oenarang 522, 577, 613.

Offers 623 .

Oland 667.

Oldenzeel 633.

Olivia 564, 632.

Ommelanden 489, 491, 502, 509, 537, $561,589,607,610,631,641,645,647$, $648,657$. 
Oost-Friesland 514.

Oostzaan 660.

Oultremont (d') 568.

Padang 659, 667.

Padangan 542, 655.

Paggeroejoeng 583.

Pahud 623, 624.

Pakoealam 530.

Palembang 517, 541, 553-555, 562, 587, $609,617,627,631,632,651,653,657$, 661.

Pallas 660.

Palm 624.

Palm (C. A.) 536, 593.

Palmer 652.

Pamanoekan 598, 616, 626.

Panaroekan 522, 570, 581.

Parakanmoentjang 556, 651.

Parvé 505.

Pasar Senen 621.

Pasar Weltevreden 525.

Paschen 602.

Pasilian 654.

Pasoeroean 484, 507, 531, 532, 549, 569, 570, 581, 586, 589, 590, 632, 659, 660.

Paterongan 643.

Pati 541.

Patjitan 517, 527, 534, 570.

Pegu 604.

Pekalongan 491, 497, 517, 537, 538, 560, 561, 564, 573, ,574, 586, 595, 598, 613, $617,630,641,660,665$.

Pemberton 485, 541, 542, 624, 625, 636, 664.

Penang 493, 526, 555, 594, 596, 605, $628,629,643,646,653,666$.

Penning Nieuwland 642.

Pennsylvanië 582.

Petel 498.

Phillips 562, 563, 600.

Phoebus 630.

Piepers 494, 531, 585, 611-613, 625, $658,661,669$.

Pitcairn 645.

Plaats (v. d.) 650.

Poeger 581.

Poegoe 598.

Poel (v. d.) 512, 538, 623, 625, 626.

Poelo Lampon 564.

Poerbodadi 542, 624.

Poerwakarta 645.

Polanen (v.) 498, 507, 537, 611.

Pondokgedeh 525, 526.
Pondoktjina 665.

Pontianak 500, 564, 565, 585.

Popkens 596, 626.

Portugal 646.

Pragata 505, 636.

Prambanan 492, 519-521, 550, 584, 601, 603, 661.

Prangwedono 530, 550, 641.

Preanger 494, 497, 525, 594, 606-608, $615,623,626,645,664$.

President 630 .

Prinsen 626, 627.

Probolinggo 488, 508, 522, 527, 531, 533, 548, 554, 569, 570, 574, 577, 581, - $606,625,641,660,662$.

Quatrebas 621.

Raban (E. M.) 570.

Raban (W.) 513, 594, 627.

Rach 652.

Radjagaloeh 506.

Raffles (H.) 511, 546.

Raffles (L.) 510, 597.

Raffles (M. A.) 544-546.

Raffles (Th. S.) passim.

Ramsay 583.

Ranzow (v.) 605, 635.

Rauws 627, 628.

Reede tot de Parkeler (v.) 518.

Reep 628.

Regensburg 665.

Reily 628.

Reinwardt 667.

Rembang 531, 532, 536, 546, 547, 562, $566,567,593,594,643,648,651,655$, $656,663,664,668$.

Reynst 619.

Richmond 649.

Rickets 611.

Ridderhoven 636.

Riemsdijk (v.) $615,622$.

Riemsdijk (A. H. L. v.) 498.

Riemsdijk (C. J. v.) 543.

Riemsdijk (C. L. v.) 646.

Riemsdijk (I. C. M. v.) 507.

Riemsdijk (J. Th. of Th. J. v.) 495, 645.

Riemsdijk (W. H. H. v.) 562 .

Riesz 524.

Rietmalen 627.

Robertson 624, 628.

Robinson 491, 628-630, 648.

Robison 494, 517, 531, 549, 554, 609, $611,613,628,630-632,657$. 
Rochussen 659.

Rockus 557.

Roelofs 610.

Roesler 605, 634.

Romswinckel 525 .

Roock (de) 543.

Roode 669.

Roos 632.

Roseboom 642.

Ross (J. C.) 564, 565, 632, 633.

Ross (J. Th.) 589, 633, 634.

Ross (county) 599.

Rothenbuhler 591, 600, 634.

Rotterdam 598, 649, 650.

Roubaud 502.

Roxburgh 533, 549, 570, 634-636.

Ruddall 636.

Rugaud 661.

Rungpore 500.

Rustenburg 489, 631, 632.

Rijck (A. v.) 507 .

Rijck (A. W. v.) 495, 507, 616.

Rijck (D. A. v.) 501 .

Rijck (G. C. v.) 507.

Rijswijk 508, 520, 531, 554, 580, 612 . $619,632$.

\section{Sack 636.}

Sagara Nooka 603.

Saksen 665.

Salamanca 540.

Salatiga $502,503,518,550,576,586$, $588,592,595,622,627,647,659$.

Saleh $636-641$.

Salis (de) 561, 595, 641, 642, 648.

Samarang 484 -487, 489-492, 496-498, $500,502-505,507,508,510,511,513$, $514,517,518, \quad 520-523,527-532$, $534-536,538,539,541,542,544$, $546-550,554,558,559,561-564$, $566-569, \quad 571-579, \quad 581, \quad 583,585-$ 587, 591-594, 597, 598, 601, 603, 605, $611,613,614,620,622,624,625,627-$ $631,634,636-641,643,644,646,648$ $-651,654,658,661,662,664,666$, 669.

Sambas 506, 548, 554, 558, 564, 565, 585.

Samland 666.

San Domingo 551.

Saparoea 498, 512.

Sartorius 519.

Sasse 642.

Sayer 642 .
Scheitman 657.

Schenk 642.

Schiedam 498.

Schill 616, 624, 633, 642, 643.

Schimmelpenninck 621 .

Schotland 531, 580, 595, 597, 599.

Schröter 650 .

Schwerin 602.

Scipion 649.

Scott (J.) 546, 643, 653.

Scott (R.) 530, 534, 535, 547, 643, 644.

Scott (W.) 595.

Selo 576, 577.

Senn van Basel (H. L.) 626.

Senn van Basel (S. C.) 525, 645.

Senn van Basel (W. A.) 495, 615, 645.

Senn van Basel (W. H.) 495, 615.

Serampore 512, 628.

Serang 606.

Serière (de) 644, 645.

Serondol 492, 546, 550.

Servatius 508, 524, 645.

Seton 646.

Sevenhoven (v.) 493, 584, 602, 646, 651.

Sevestre 510, 646, 647.

Shrapnell 531, 555, 603, 616, 626, 647, 648, 656 .

Siam 604.

Siberg 495, 524, 536, 615 .

Sidajoe 484, 581, 656, 657, 664.

Silezië 495, 511.

Simpang 550.

Sindangbarang 525 .

Sindoro 569.

Singapore 491, 529, 533, 547, 566, 607, $610,654$.

Singosari 583.

Skelton 531, 607, 616, 626, 647, 648.

Smissaert (A. H.) 489, 514, 531, 612, 648, 649.

Smissaert (E. L.) 507.

Smith (D. J.) 619.

Smith (J. F.) 649.

Soady 649, 660 .

Soedimara 515, 648.

Soedjak 637.

Soekaboemi 664 .

Soekapoera 504, 556, 599, 649, 651.

Soekawati 586 .

Soekoe 588.

Soekoer 638, 639, 641.

Soeloe 584, 585 .

Soemadi 637. 
Soemedang 543, 545, 599, 638, 651.

Soemedangan 525 .

Soemenap 516, 534, 538, 548, 566, 605, $608,622,641,660,668$.

Soemo Negoro 638.

Soenda 487, 547, 580.

Soerabaja 484, 485, 489, 490, 496, 503, $510,513,516,517,523,524,527,528$, $530,531,533-535,541,542,550,557$ $-559,562,564,566,570,571,573-$ 577, 580, 585-587, 590, 592, 594, 597, $600,601,604,612,614,618,622,623$, $625,627-629,634,636,642,655,660$ $-662,664,669$.

Soerakarta, zie Solo.

Solo 484, 492, 503, 507, 508, 514, 542, $544,559,566,567,569,573-579,582$, $583,586,588,589,592,593,601,630$, $642,645,662,667$.

Solo-rivier 516, 543, 655, 656.

Son (v.) 507.

Sontar 646.

Spanje 571.

Spencer 586.

Steenbrugge 649.

Steinmetz 514.

Steitz 509.

Stettin 668.

Steyn Parvé 525.

Stokkie 654.

Stopford 544, 642, 649.

Stornoway 599.

Stralendorff (v.) 567, 583.

Stralsund 550 .

Struiswijk 626.

Stuttgart 634.

Supper 649, 650 .

Tambora 488.

Tanahabang 496, 568, 596, 644.

Tandjoengpoera 487 .

Tandjoengpriok 654.

Tangkoeban Prahoe 584 .

Taylor 508, 509, 528, 549, 650, 662.

Tegal 500, 501, 532, 540, 543, 544, 571, $572,587,590,594,626,630,650,655$, $657,668,669$.

Tegalwaroe 525 .

Telong 655 .

Templer 508, 509 .

Tency 554, 606, 651.

Tenggeragoeng 598.

Ternate 665 .
Terreneau 651.

Teviotdale 596.

Texel 667.

Teylingen (C. W. E. v.) 657.

Teylingen (D. G. v.) 651.

Teylingen (P. I. v.) 532, 542, 650, 651, 666.

Thierens 665 .

Thompson 544.

Thorn 551-556, 651, 652 .

Tieleman 654 .

Tielenius Kruythoff 508, 536, 645.

Timmerman Thijssen 494, 652, 653.

Timor 488,580 .

Tinawoen 655,656 .

Tjabangboengin 654 .

Tjandi Sewoe 518, 584.

Tjandjoer 497, 509, 524, 538, 578, 642, $660,665$.

Tjiasem 487, 598, 616.

Tjiawi 525 .

Tjibinong 608 .

Tjilatjap 493.

Tjilembar 525 .

Tjilintjing 600, 649.

Tjilodong 667.

Tjiloewar 554 .

Tjimanggis 498, 554, 622 .

Tjimanoek 569 .

Tjinere 525 .

Tjiomas 525 .

Tjipanas 553, 554 .

Tjisaroewa 525,637 .

Tjitjoeroek 525 .

Toeban 538, 649.

Toegoe 518, 603.

Toulon 571 .

Trail 666.

Tranquebar 524, 645.

Travers 530, 546, 609, 619, 636, 643, $653,654$.

Trinconomale 602 .

Trogong 664.

Troost 641.

Trowt 650, 654 .

Tucker 654 .

Tulloch 525 .

U1ster 551.

Union 558 .

Utrecht 610, 667.

Valck 598.

Veeckens 593, 651, 654. 
Veendam 617.

Veeris 655.

Veldtman Muntinghe 617, 634.

Vellore 551.

Verhage $655-657$.

Ver Huell 617.

Verster 657.

Villarubi 657.

Villeneuve 568, 658, 659, 663.

Vincent 626, 659.

Vlietlust 567.

Vodegel 592, 659.

Vogelaar 626.

Vorstenlanden 488, 491, 492, 518, 523, $527,530,534,558,566,570,571,573$, $576,583,584,600,624,630,631,653$, $655,667$.

Vos 569, 659, 660.

Vriese 660 .

Waal (de) 660, 668.

Waanders 661.

Waeij (v.) 497, 518, 651, 655.

Wageningen 567.

Wallis 632.

Walther 624.

Walworth 511.

Wanajasa 607, 626.

Wardenaar (J. W. B.) 601, 602, 661, 662.

Wardenaar (W.) 488, 501, 562, 661.

Waterford 636.

Waterloo (M.) 594, 662.

Waterloo (S. F.) 536.

Watson 484, 541, 605, 662, 663.

Wedde 525 .

Wedding 612, 663.

Wellesley 580 .
Wellington 571.

Weltevreden 489, 523, 525, 549, 553, $554,587,588,621,622,625,628,651$, $654,663,669$.

Wens 614.

Werff (v. d.) 594, 663.

Westermann 494, 612, 652.

Western Districts 498, 504.

Westphal 615.

Wetherall 519.

Wiese 557, 614.

Wilde (de) 502, 509, 660, 664.

Williams 605, 618, 625, 664.

Wilson (H. H.) 599, 603, 604.

Wilson (J. G.) 665.

Wiltenaer 665.

Winckelmann (C. v.) 536, 665.

Winckelmann (F. v.) $651,665,666$.

Winter 593.

Wirosari 542.

Wirosobo 567, 586, 589.

Wood (kap.) 530, 562.

Wood (overste) 630.

Wurttemberg 649, 665, 669.

Wijnkoopsbaai 514 .

Young 491, 666, 667.

Ysseldijk (v.) 651, 667.

Yule 487, 548, 593, 608, 607, 660, 667, 668.

Zhaetzcky 590, 668, 669.

Zierikzee 642 .

Zimmer 608, 658, 659, 669.

Zutphen 665.

Zweibrücken 634 .

Zwekkert 669.

Zwolle 540, 568. 
